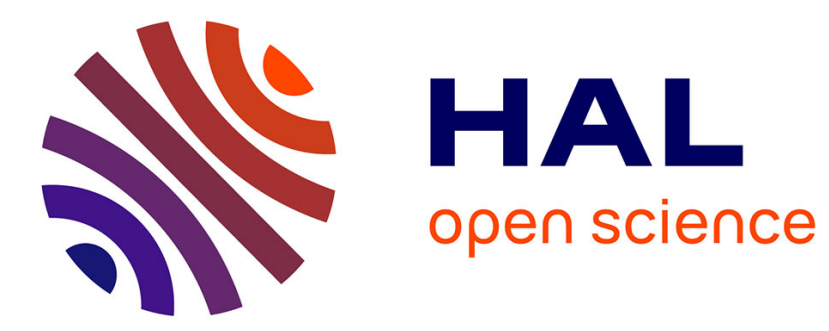

\title{
Développement des Fonctions Exécutives chez les Enfants Libanais
}

Cynthia Roukoz

\section{To cite this version:}

Cynthia Roukoz. Développement des Fonctions Exécutives chez les Enfants Libanais. Psychologie. Université d'Angers, 2020. Français. NNT : 2020ANGE0028 . tel-03272729

\section{HAL Id: tel-03272729 \\ https://theses.hal.science/tel-03272729}

Submitted on 28 Jun 2021

HAL is a multi-disciplinary open access archive for the deposit and dissemination of scientific research documents, whether they are published or not. The documents may come from teaching and research institutions in France or abroad, or from public or private research centers.
L'archive ouverte pluridisciplinaire HAL, est destinée au dépôt et à la diffusion de documents scientifiques de niveau recherche, publiés ou non, émanant des établissements d'enseignement et de recherche français ou étrangers, des laboratoires publics ou privés. 


\section{DOCTORAT/EDUCATION}

\section{BRETAGNE LANGAGES, INTERACTIONS}

LOIRE / COGNITION, CLINIQUE

\section{THESE DE DOCTORAT DE}

\section{L'UNIVERSITE D'ANGERS}

ECOLE DOCTORALE N ${ }^{\circ} 603$

Education, Langages, Interaction, Cognition, Clinique

Spécialité : "Psychologie »

\section{Par \\ « Cynthia ROUKOZ »}

« Développement des Fonctions Exécutives chez les Enfants Libanais »

Thèse présentée et soutenue à « Beyrouth », le « 17/12/2020 »

Unité de recherche: Laboratoire de Psychologie des Pays de la Loire, EA4638

\section{Composition du Jury:}

Monsieur Tarek Bellaj

Professeur associé

Qatar University, Qatar Rapporteur

Mme Leila Dirani

Professeur associé

American University of Beirut

Dir. de these:

Monsieur Arnaud Roy

Professeur

Université d'Angers, France

Co-dir. de thèse:

Monsieur Didier Le Gall

Professeur

Université d'Angers, France 
L'auteur du présent document vous autorise à le partager, reproduire, distribuer et communiquer selon les conditions suivantes :

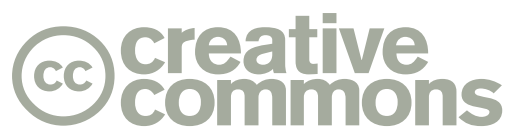

- Vous devez le citer en l'attribuant de la manière indiquée par l'auteur (mais pas d'une manière qui suggérerait qu'il approuve votre utilisation de l'œuvre).

- Vous n'avez pas le droit d'utiliser ce document à des fins commerciales.

- Vous n'avez pas le droit de le modifier, de le transformer ou de l'adapter.

Consulter la licence creative commons complète en français : http://creativecommons.org/licences/by-nc-nd/2.0/fr/

Ces conditions d'utilisation (attribution, pas d'utilisation commerciale, pas de modification) sont symbolisées par les icônes positionnées en pied de page.

Roukoz Cynthia | Développement des Fonctions Exécutives chez les Enfants 2 
Je commence par remercier toutes les personnes qui ont contribué au succès de ce travail et qui m'ont aidé lors de la rédaction de cette thèse.

Je voudrais, dans un premier temps, remercier mon Directeur de thèse, M. Arnaud Roy, qui, au cours de ces dernières années, malgré la distance géographique qui nous séparait et son emploi de temps très chargé, a été disponible à tout moment pour accompagner ma réfléxion et calmer mes angoisses. Il a également montré une grande curiosité de mon contexte culturel et à travers ses questions, m'a éclairé sur différents aspects de mon pays.

Je remercie également M. Le Gall, qui, depuis mon premier entretien en 2013, m'a donné une chance en acceptant ma candidature en Master 2. Il m'a accompagné durant mon déménagement en France et m'a aidé à intégrer la culture et travailler sur mes lacunes. Tout au long de ce travail de thèse, il a été disponible avec des conseils judicieux qui ont contribué à alimenter mes réflexions.

Merci à Amanda et Marie. Nous avons partagé toutes les étapes de ce travail et vous avez été à mon écoute tout en partagant vos expertises respectives. Malgré la distance qui nous separait, vous avez été des amies et des confidentes.

Merci à Mme Ghannage et aux étudiants de l'USJ pour l'intérêt porté à cette étude.

Merci aux familles et aux enfants qui ont participé à ce travail.

Pia, thank you for your mentoring, your support, your faith in my knowledge and expertise, your valuable suggestions expecting nothing in return, and your neverending friendship.

Hussein, thank you for your kindness, your help with all those tricky Arabic words, and your availability whenever needed.

Rawad, on a vécu beaucoup de hauts et de bas toutes ces années. Malgré tous les obstacles recontrés, tu m'as toujours encouragée à completer cette thèse et tu ne m'as jamais laissée baisser les bras. A travers nos longues discussions philosophique, politique et sociologique au balcon, j'ai souvent trouvé mon inspiration et des réponses à mes questions. Je n'y serais jamais arriver sans toi.

A Anthony, ce travail t'est dédié. Ma plus grande motivation était l'espoir de t'offrir un avenir plus stable.

A ma famille, mes amis, et mes collègues au Liban, je vous remercie pour votre positivité, jovialité et résilience que vous avez su me transmettre. D'une manière ou d'une autre, chacun de vous a contribué au succès de ce travail. Rappelez vous, "il est des terres brûlées donnant plus de blé qu'un meilleur avril". Guardez espoir. 
Table de Matière

1. INTRODUCTION _...................................................................................................

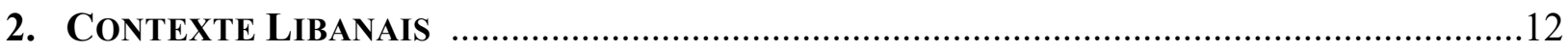

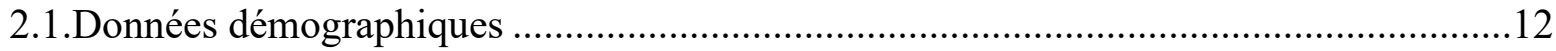

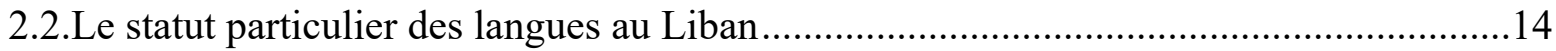

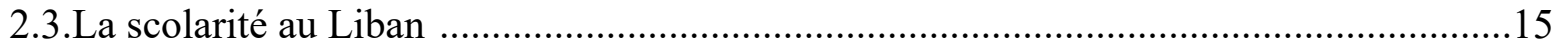

2.4.Les valeurs Libanaises........................................................ 17

2.5.La psychologie de l'enfant au Liban .......................................................................... 18

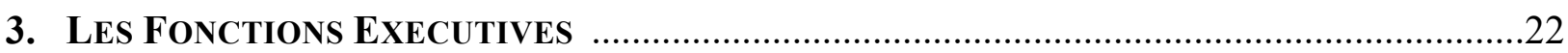

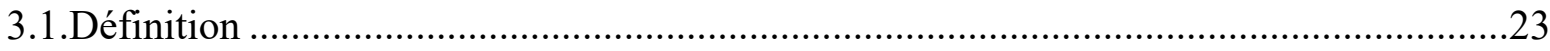

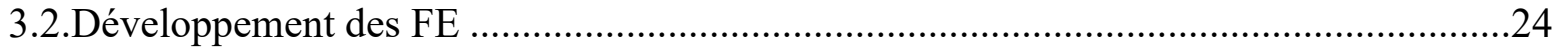

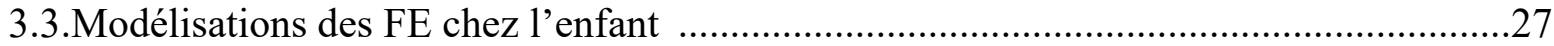

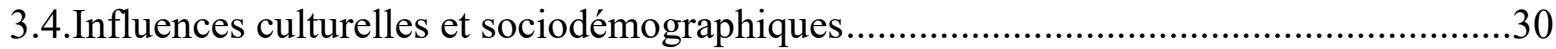

3.5.L'évaluation des FE chez l'enfant................................................ 55

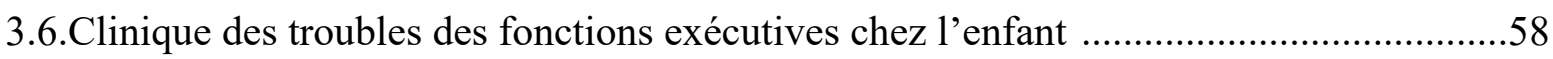

4. Problematique, obJectifs et hypotheses $\ldots$..........................................................62

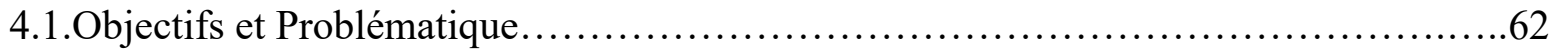

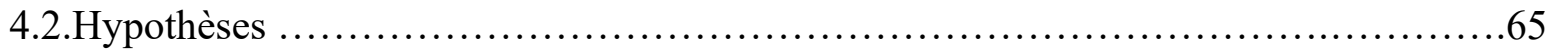

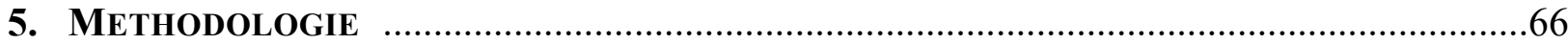

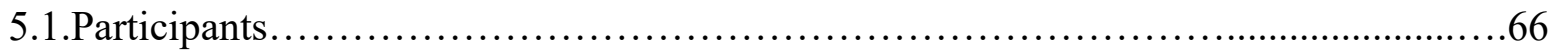

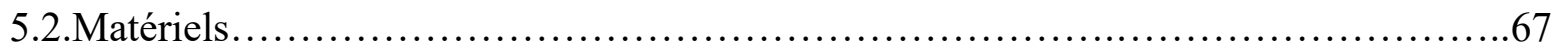

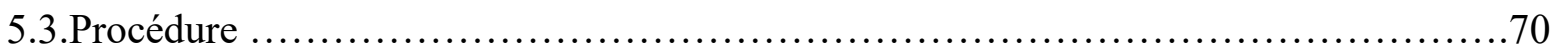

6. ETUDE 1: DEVELOPPEMENT DES FE AUPRES DE LA POPULATION LIBANAISE ................72

7. ETUde 2: CAS CliniQue: FE CHEZ UN ENFANT LIBANAIS AVEC UNE EPILEPSIE DU LOBE

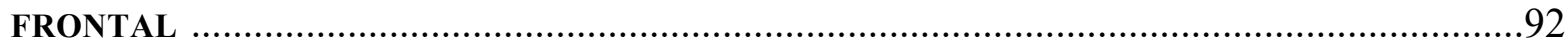

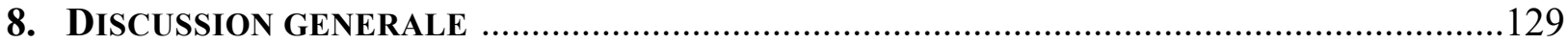

8.1.L'adaptation méthodologique du protocole FEE.................................. 130

8.2.Le développement typique des FE chez les enfants Libanais........................131

8.3.L'influence des facteurs sociodémographiques sur le développement des FE..........134

8.4.L'évaluation des FE chez un enfant Libanais avec ELF...........................138 Roukoz Cynthia $\mid$ Développement des Fonctions Exécutives chez les Enfants 4 


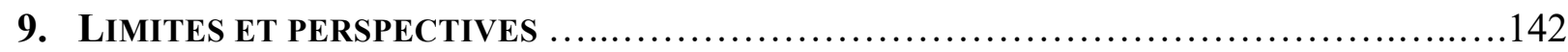

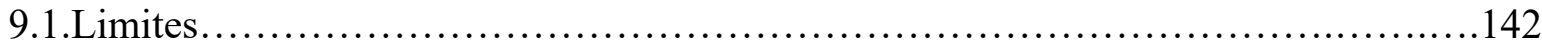

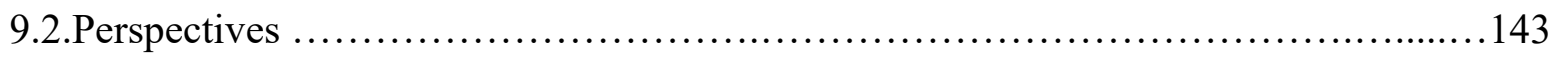

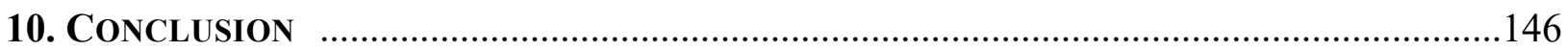

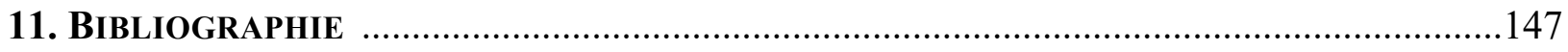

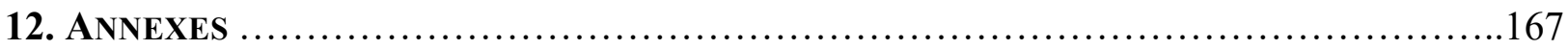

Annexe 1 : Article scientifique paru en Mars 2017.

Er-Rafiqi, M., Roukoz, C., Le Gall, D. \& Roy, A. (2017). Les fonctions exécutives chez l'enfant: développement, influences culturelles et perspectives cliniques. Revue de Neuropsychologie, neurosciences cognitives et cliniques, 9(1), 27-34.

Annexe 2 : Chapitre de livre paru en Aout 2018.

Er-Rafiqi, M., Roukoz, C., Le Gall, D. \& Roy, A. (2018). Fonctions exécutives, environnement et contexte chez l'enfant. In A. Roy, B. Guillery-Girard, G. Aubin \& C. Mayor (Eds.), Neuropsychologie de l'enfant (pp. 169-186). Paris: De Boeck superieur.

Annexe 3 : Notice d'information et formulaire de consentement (version libanaise).

Annexe 4 : Questionnaire d'exclusion et d'inclusion (version libanaise).

Annexe 5 : PABIQ (Parents of Bilingual Children Questionnaire) questionnaire pour parents d'enfants bilingues version Arabe.

Annexe 6 : Behavioral Rating Inventory of Executive Function in Children (Parent form), adaptation Arabe. 


\section{Table des Figures}

Figure 1 : Carte montrant la répartition, sur le terrain Libanais, des habitants selon leurs groupe

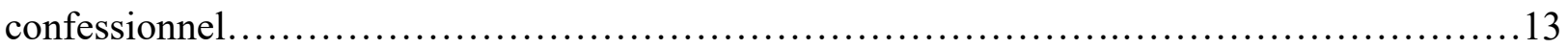

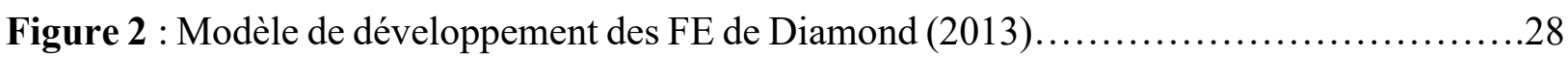

Figure 3 : Tests du protocole FEE................................................57

Figure 4: Etapes nécessaires à l'adaptation d'un outil de sa langue d'origine à sa langue cible.

\section{Liste des Tableaux}

Table 1 : An overview of studies on cross-cultural comparison of EF in children...............35

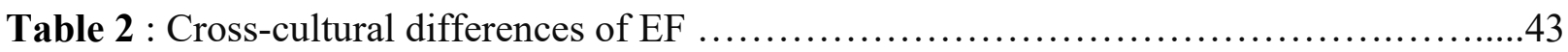

Table 3: Executive Function measures used across studies.................................44

Table 4: Studies that found cross-cultural differences................................45

Table 5: Répartition des enfants Libanais par catégories d'âges, genre, niveau d'éducation maternel et niveau d'éducation paternel.............................................67

Table 6: présentation et description des tests issus de la batterie FEE et inclus dans le protocole

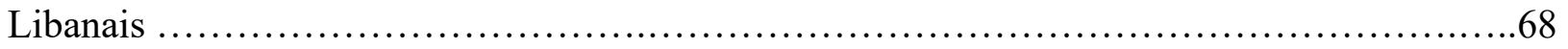

Table 7: Demographic Data for the sample study........................................ 77

Table 8: Subtest description of the Lebanese adaptation of the CEF-B $\ldots \ldots \ldots \ldots \ldots \ldots \ldots \ldots \ldots .78$

Table 9: Descriptive Data for Executive Indices by Age and Age effects.....................80

Table 10: Descriptive Data for Executive Indices by gender and gender effects...............82

Table 11: Descriptive Data for Executive Indices by level of education of parents.............82

Table 12: Tests administered by function......................................... 104

Table 13: Values of scores in the average and impaired range ............................ 108

Table 14: Results on the neuropsychological test measures organized by tests

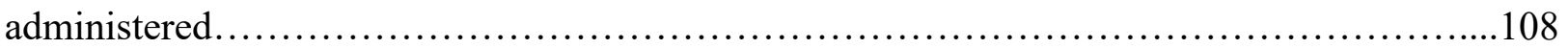

Table 15. Results on the Arabic version of the CEF-B subtests organized by EF.............112

Table 16. Results on the Arabic version of the BRIEF (Parent form)........................ 114

Table 17. Effet du niveau d'éducation parental sur les tests de FE............................135 


\section{Introduction}

Ce projet de thèse est l'aboutissement de plus de 4 ans d'observation et d'étude d'enfants qui se développent et grandissent dans un contexte culturel que j'aimerais qualifier d'hybride et complexe. Il a été initié peu après avoir été introduite à la Neuropsychologie et plus spécifiquement, à la Neuropsychologie de l'enfant, au cours de mon passage en France dans l'objectif de réaliser un Master de Neuropsychologie à l'université d'Angers en 2013.

Ma rencontre avec Pr. Arnaud Roy, Pr. Didier Le Gall et leurs équipes m'a initiée à une question fondamentale à laquelle je ne m'étais jamais sérieusement et scientifiquement attardée et qui concerne la différence transculturelle du développement cognitif et comportemental des enfants. Il y a 5 ans de cela, je conceptualisais le développement cognitif comme universel, ne dépendant pas de la culture, mais uniquement de l'âge chronologique d'un enfant. Depuis, avec plus d'opportunités de côtoyer des enfants issus de différentes cultures et plus de maturité dans mon observation opérationnelle et objective d'enfants en développement, mes représentations ont évolué. Ainsi, le questionnement fondamental était de s'interroger sur le développement cognitif des enfants Libanais, étant donné que les études en la matière sont quasi-absentes auprès de cette population.

Plus spécifiquement, nous nous questionnions sur le développement des fonctions exécutives (FE) et l'influence de la culture sur ces fonctions dites « frontales ».

Nous avions décidé de nous focaliser sur les FE parce que les enjeux scientifiques et cliniques que représentent les FE sont multiples. D'abord, il est reconnu que les FE sont associées à la réussite scolaire d'un enfant, à sa qualité de vie voire à sa santé mentale ou physique (Diamond, 2013). L'importance du contrôle exécutif a même été discuté bien avant, en 1972, par le psychologue Walter Mischel avec la célèbre expérience du Stanford marshmallow experiment. A travers cette expérience, les auteurs ont démontré que les enfants capables de retarder une gratification (le plaisir que procurait un marshmallow ou un pretzel), montraient plus tard de meilleures performances scolaires, une meilleure forme physique et une meilleure qualité de vie (Mischel \& Ebbesen, 1970). La capacité d'un enfant à retarder une gratification est intrinsèquement liée à ses capacités d'inhibition et de contrôle.

Roukoz Cynthia | Développement des Fonctions Exécutives chez les Enfants 7 
Les FE se définissent comme un ensemble de fonctions de contrôle de haut niveau prenant en charge le comportement orienté vers un but (Miller \& Cohen, 2001). Diamond (2013) met ainsi les FE au cœur du développement psychologique, émotionnel, et cognitif d'un enfant. De plus, le statut développemental particulièrement prolongé des FE chez l'enfant (Roy et al., 2012), l'intrication du développement des FE avec le contexte d'un enfant (Roukoz et al., 2018), ainsi que la vulnérabilité précoce des régions préfrontales et de leurs réseaux (siège principal des FE dans le cerveau) (Roy et al., 2012), rend l'étude des FE chez l'enfant particulièrement importante. Les lésions des réseaux préfrontaux affecteraient souvent des fonctions encore émergentes, les rendant particulièrement vulnérables (Roy et al., 2012). Ainsi, l'étude des FE représente un enjeu scientifique important dans la compréhension de son développement et de son impact dans les autres acquisitions cognitives, dans les apprentissages, dans les acquisitions sociales, et dans le comportement de l'enfant.

De plus, compte tenu des nombreuses études récentes montrant une potentielle influence du contexte et de la culture sur le développement des FE (Chasiotis et al. 2006; Roukoz et al., 2018; Sabbagh et al. 2006), l'étude des FE dans différents contextes culturels semble particulièrement pertinente tant dans un intérêt clinique que théorique. Cliniquement, ce travail vise l'établissement d'outils de FE adaptés à la population libanaise ainsi que la description du syndrome dyséxecutif chez un enfant libanais. D'un autre côté, les apports théoriques de cette étude concernent une meilleure compréhension des dimensions de la cognition, qui devrait s'inscrire dans la perspective d'un relativisme culturel plutôt qu'universaliste (Bruner, 1966).

Dans cette perspective, le projet FEE (Fonctions Exécutives chez l'Enfant), proposé par un groupe de recherche multicentrique coordonné par les laboratoires de recherche des universités d'Angers et de Savoie Chambery (Roy, Fournet, Le Gall, \& Roulin), a été initié en 2009. Le protocole FEE a été conçu dans l'objectif de mettre à disposition des cliniciens français des outils d'évaluation des FE et de favoriser la reconnaissance du syndrome dysexécutif auprès de la population clinique. Ce projet s'est graduellement inscrit dans une perspective internationale débouchant sur une validation de l'outil dans différents pays, parmi lesquels la Tunisie, le Brésil, le Liban et le Maroc, en suivant une méthodologie commune. Ainsi, le protocole FEE a été adapté à langue Arabe et à 
la population libanaise et a rendu possible l'étude du développement des FE auprès de cette population. Ce travail de thèse s'est donc focalisé sur l'étude du développement des FE auprès de la population libanaise afin d'aboutir à une amélioration de nos connaissances sur le développement des FE et les influences sociodémographiques et intra-culturelles sur les performances exécutives des enfants Libanais.

Pourquoi le Liban ? Six millions de Libanais résident au Liban. La diaspora libanaise est estimée à près de 12.5 millions d'émigrés répartis sur les 5 continents (https://www.ministryinfo.gov.lb/). Cette diaspora entretient une relation étroite avec le Liban qui a connu plusieurs vagues de retour des émigrés après la guerre civile en 1990 (Makki, 2007), amenant avec eux des coutumes et modes de vie divers. Le peuple libanais est donc assez dispersé et, malgré cette dispersion, les Libanais partagent une culture, un héritage, et des coutumes qui, potentiellement, influencent le développement psychologique et, plus particulièrement, cognitif, des enfants.

Ma carrière en tant que Psychologue/Neuropsychologue a débuté au Liban, peu après mon retour de la France en 2013. Depuis le début de ma carrière, l'obstacle que je rencontre est l'absence de claires représentations de ce qui peut être considéré comme «normal » ou «pathologique » chez un enfant Libanais. Par exemple, ma première expérience avec le Test de l'Évaluation de l'Attention chez l'Enfant (TEA-CH) (version française) était assez problématique. La majorité des enfants auxquels j'administrais ce test montraient des résultats déficitaires, même en l'absence de symptômes ou de plaintes mentionnées par les parents ou les enseignants.

A ce jour, il n'y a aucune étude locale publiée qui s'intéresse à dresser un calendrier développemental des fonctions cognitives des enfants Libanais ce qui complique le métier de Neuropsychologue ou Psychologue de l'enfant au Liban. La majorité des tests neuropsychologiques à notre disposition ont été créés pour des populations occidentales, notamment Française, Américaine, Anglaise ou Canadienne. Ces outils sont utilisés par de très nombreux cliniciens Libanais avec la conviction que les informations qu'ils apportent sont fiables. Étant donné que la majorité des tests utilisés en Neuropsychologie sont à finalité diagnostique, les conséquences de l'utilisation de tests non-adaptés à cette population sont majeures, notamment, le risque de produire des faux positifs ou des faux négatifs en matière de difficultés cognitives. Par ailleurs, les études récentes montrant une influence du contexte culturel et Roukoz Cynthia | Développement des Fonctions Exécutives chez les Enfants 9 
sociodémographique sur le développement des FE (Roukoz et al., 2018) nous conduisent à nous interroger sur les limites des modélisations actuelles du développement des FE. En effet, aucune des modélisations des FE disponibles pour l'enfant, ne prend en compte les potentielles influences culturelles sur le développement des FE. Cette lacune ne permet pas de généraliser les données disponibles aux différents contextes culturels.

La détérioration de la qualité de vie des Libanais a conduit à un accroissement considérable des troubles de santé mentale chez les enfants et les adolescents Libanais (Baroud et al., 2019a; Baroud et al., 2019b; Chahine et al., 2020). Ces troubles sont d'ailleurs susceptibles d'affecter le développement cognitif et exécutif de ces enfants (Malarbi et al. 2017; McDermott \& Ebmeier 2009; Owens et al. 2012). De plus, la crise socio-économique et politique libanaise a été amplifiée par une explosion catastrophique au cœur de Beirut, laquelle a généré de nombreux traumatismes crâniens chez les enfants Libanais, traumatismes crâniens souvent responsables de troubles majeurs des FE (Levin \& Hanten, 2005; Sesma et al. 2008).

Ce travail de thèse revêt donc une importance particulière tant sur le plan théorique que clinique et pourra servir à tout clinicien travaillant auprès d'enfants libanais présentant ou susceptible de présenter des troubles des FE.

Dans la première partie de ce travail, nous présenterons quelques données démographiques et socio-culturelles afin de permettre une meilleure compréhension du contexte libanais et de ses enjeux. Nous y présenterons également certaines données relatives au développement de l'enfant et à la pratique de la psychologie et neuropsychologie au Liban. Ceci nous permettra d'illustrer les besoins et les enjeux que représente l'étude des FE au Liban. Nous poursuivrons par un deuxième chapitre théorique au sein duquel nous présenterons les modèles théoriques pertinents des FE chez l'enfant. Dans ce deuxième chapitre, un article publié dans le cadre de cette thèse sera présenté (Roukoz et al., 2018). L'article s'intitule « A Systematic Review of Cross-Cultural Studies on Executive Functions in Children » et a été publié dans 1'International Journal of Psychology and Neuroscience, revue à comité de lecture d'audience internationale. L'objectif était d'y dresser une revue systématique de la littérature en se focalisant plus particulièrement sur les différences transculturelles du développement des FE dans l'enfance. Dans le cadre de l'élaboration de ce chapitre de thèse, un article et un chapitre de livre ont également été publiés en collaboration avec 
d'autres chercheurs. Er Rafiqi, Roukoz, Le Gall, Roy, (2017) ont dressé une synthèse des connaissances actuelles sur les FE chez l'enfant et les enjeux de l'évaluation clinique des FE (Annexe 1). Enfin, un autre chapitre d'ouvrage a été publié en collaboration avec d'autres auteurs présentant une synthèse des connaissances actuelles sur les FE et les influences culturelles et sociodémographiques sur leur développement (Er-Rafiqi et al., 2017) (Annexe 2).

Le troisième chapitre rappelle la problématique et les hypothèses ainsi que la méthodologie. Dans un quatrième chapitre, nous présenterons un deuxième article soumis dans une autre revue internationale à comité de lecture (Developmental Neuropsychology) intitulé : «Development of Executive Functions in Lebanese Children ». Cet article présente les données développementales des FE chez des enfants Libanais d'âges scolaires. Le cinquième chapitre propose l'observation clinique d'un enfant avec une Epilepsie du Lobe Frontal (ELF) afin d'illustrer ce que pourrait être l'évaluation d'un enfant Libanais présentant un syndrome Dysexécutif à l'aide d'outils adapté à la langue Arabe et à la population Libanaise. Ce cas clinique est présenté dans un article intitulé «A Neuropsychological Clinical Case Study of Executive Function in a Child with Frontal Lobe Epilepsy», soumis dans la revue Epilepsy and Behavior Reports. Finalement, nous discuterons l'ensemble des résultats et des enjeux de cette thèse avant de présenter ses limites et perspectives.

Roukoz Cynthia $\mid$ Développement des Fonctions Exécutives chez les Enfants 11 


\section{CONTEXTE LibANAIS}

\subsection{Données démographiques}

Le Liban est un pays Méditerranéen du Proche-Orient qui partage ses frontières avec la Syrie et l'Israël et qui se trouve le long de la côte méditerranéenne avec Chypre à l'Ouest. La capitale du Liban est Beyrouth et la langue officielle est l'Arabe bien que le Français et l'Anglais demeurent les langues employées dans l'enseignement tant privé que public et gardent une place intégrale dans le monde du commerce et dans la société. Le Liban est un pays indépendant depuis 1943, quand il a pris son indépendance après une colonisation Française qui a duré 23 ans. La langue Française, bien qu'ayant perdu son statut officiel au Liban, reste dans la constitution. Le Liban est un pays pluriconfessionnel : les religions sont réparties en 18 confessions reconnues par l'État et représentées politiquement dans l'assemblée nationale libanaise vu qu'à ce jour, le système politique Libanais est fondé sur le confessionnalisme.

Les religions sont principalement musulmanes et chrétiennes mais également Druzes. Les religions musulmanes sont en majorité des chiites et sunnites et les chrétiens sont en majorité des maronites, suivis par des grecs orthodoxes et des grecs catholiques. Géographiquement, les Libanais sont souvent partagés sur le territoire en fonction de leurs religions tel qu'illustré dans la figure 1. Les sunnites sont concentrés au centre de Beyrouth et dans le nord du pays, les chiites dans la banlieue de Beyrouth, au sud du Mont-Liban et dans le nord de la plaine de la Bekaa. Les maronites et les grecs orthodoxes sont plutôt rassemblés en périphérie (Mont Liban) et dans Beyrouth, ainsi que dans la moitié nord du Liban. Les druzes, enfin, sont regroupés au Sud du Mont-Liban.

Roukoz Cynthia | Développement des Fonctions Exécutives chez les Enfants 12 Libanais @) $\Theta \Theta$ 


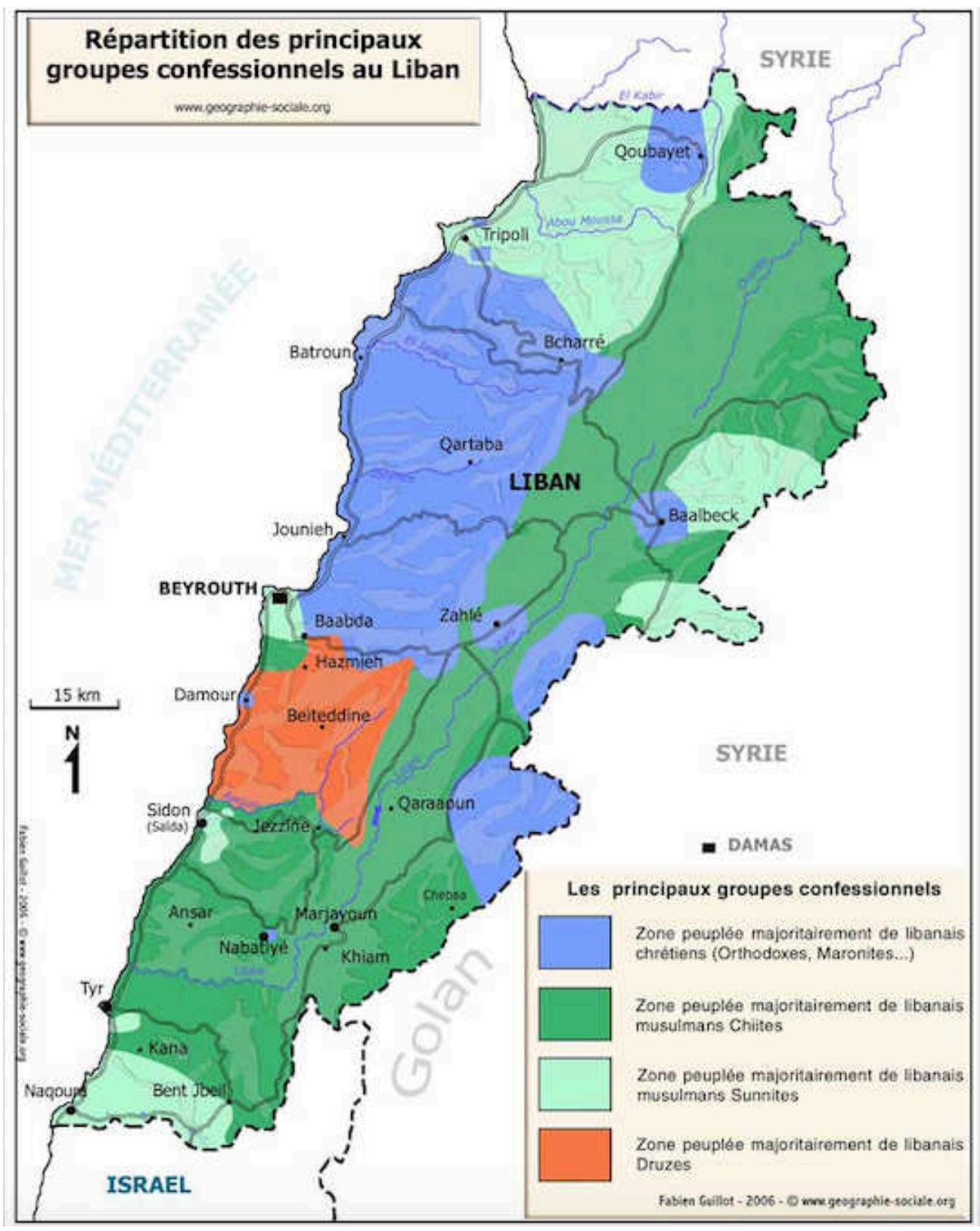

Fig.1 : Carte montrant la répartition, sur le terrain Libanais, des habitants selon leurs groupe confessionnel. Source : http://www.geographie-sociale.org/Carte-liban-religion.php

En 2019, la population était estimée à 6.8 millions de personnes vivant au Liban, avec une estimation de 1078388 refugiés selon United Nations High Comissioner Refugees (UNHCR)

Roukoz Cynthia | Développement des Fonctions Exécutives chez les Enfants 13 Libanais @(1) $\Theta \Theta$ 
(https://www.unhcr.org/lb/) en 2015. La majorité des réfugiés sont Palestiniens et Syriens (https://www.unhcr.org/lb/).

Selon le ministère de l'information de la République Libanaise (https://www.ministryinfo.gov.lb/), la diaspora libanaise est estimée à 12.5 millions de personnes. Ce nombre important est lié aux nombreuses guerres que le Liban a connues- La plus importante fût la Guerre Civile qui a duré entre 1975 et 1990. Ainsi, le Liban est un pays qui est actuellement en voie de reconstruction, 30 ans après la guerre civile.

La pluralité des religions donne naissance à plusieurs coutumes et habitudes de vie différentes. Certaines familles, de part leurs religions, disposent d'un mode de vie conservateur, alors que d'autres adoptent un mode de vie plutôt inspiré des pays occidentaux. Une grande partie des familles Libanaises a émigré pour quelques années, voire plus, pendant la guerre civile et plusieurs sont rentrés au Liban une fois la guerre terminée, apportant avec eux des modes de vie occidentaux mélangés à une éducation moyen-orientale. Par ailleurs, un nombre significatif de familles Libanaises est partagé entre le Liban et des pays étrangers, compte tenu du statut économique fragile du pays qui explique un taux de chômage élevé et donc un taux d'immigration important. Une autre particularité du Liban, probablement dû aux nombreux retours d'immigrés au cours des dernières années, est son contexte multilangagier.

\subsection{Le statut particulier des langues}

Le Liban est considéré comme un pays ayant un contexte multilangagier et multiculturel complexe (Bahous et al. 2011). La langue officielle nationale est l'Arabe et la majorité des Libanais utilisent le dialecte Libanais vernaculaire (derej ou دارج), qui fait partie de l'Arabe Levantin, comme mode de communication au quotidien. Les Libanais sont aussi exposés à l'Arabe Moderne Standard (فSA ou فصحى) comme langue officielle dans les journaux, nouvelles télévisées, ou autres modes de communication officiels. Il est important de mentionner que les deux dialectes, bien qu'ayant certaines similarités, présentent des différences majeures au niveau syntaxique, morphologique et lexical (Holes, 2005). Ainsi, l'Arabe libanais est un modèle classique d'une langue diglossique où deux variétés d'une même langue sont utilisées dans une même communauté (Ferguson, 1959). En plus d'être exposés à deux formes d'une même langue, les Libanais, dans leur grande majorité, sont bilingues ou trilingues. Le Français et l'Anglais gardent une place majeure dans l'éducation

Roukoz Cynthia | Développement des Fonctions Exécutives chez les Enfants 14 
et dans le monde du commerce au Liban. Vingt pour cent de la population Libanaise utilise une langue étrangère (Français ou Anglais) dans leur quotidien comme premier mode de communication et, avec le temps, on s'attend à un accroissement, auprès de la jeunesse Libanaise, de l'utilisation de langues étrangères et une diminution de l'utilisation du dialecte Libanais (Shawish, 2010).

\subsection{La scolarité au Liban}

En ce qui concerne la scolarité, l'école au Liban est obligatoire de 6 à 15 ans. Si les études après le Brevet sont facultatives, la majorité des jeunes Libanais continuent leurs études jusqu'à l'université. Le taux de scolarisation net du Liban, en 2012, était estimé à 97\%, ce qui correspond au taux des pays développés (https://www.crdp.org/). D'ailleurs (https://www.unicef.org/french/infobycountry/lebanon_statistics.html/), le Liban est perçu comme l'un des États du Moyen Orient où le taux de scolarisation figure parmi les plus élevés, avec un taux d'alphabétisation de $91 \%$ chez les adultes et $99 \%$ chez les jeunes.

Les statistiques du ministère de l'éducation et de l'éducation supérieure, au cours de l'année 2018, montrent que $51.4 \%$ des écoles libanaises offrent une éducation avec le Français comme première langue d'instruction contre $48.6 \%$ pour l'Anglais (Centre de Recherche et de Développement Pédagogique, 2018). Les enfants libanais commencent à apprendre le Français ou l'Anglais, et souvent les deux simultanément, en période préscolaire dans les écoles privées et dans la majorité des écoles publiques (Shaaban \& Ghaith, 1997). Les cours de Français et d'Anglais sont offerts en moyenne 8 heures par semaines dans les classes élémentaires et sont utilisés comme langue d'instruction pour l'éducation des mathématiques et des sciences, incluant tous types de sciences sociales (géographie, histoire, économie, philosophie, etc.).

Bien que la majorité des élèves Libanais reçoivent une éducation francophone, la proportion des élèves fréquentant les écoles francophones au Liban est en constante diminution, en faveur des établissements anglophones. Les examens officiels, soit le Brevet et Baccalauréat Libanais, peuvent se faire, au choix, en Français ou en Anglais, dépendamment de l'institution scolaire de l'enfant. Le Baccalauréat Français ainsi que le Baccalauréat International sont également reconnus par l'État comme équivalents au Baccalauréat Libanais. Certaines écoles privées (notamment les

Roukoz Cynthia $\mid$ Développement des Fonctions Exécutives chez les Enfants 15 
écoles homologuées Françaises) encouragent la passation des deux Baccalauréats, Libanais et Français.

Les écoles libanaises sont soit privées soit publiques. Les écoles publiques libanaises sont financées par le ministère de l'éducation et de l'éducation supérieure. Au Liban, la majorité de l'éducation est assurée par des établissements privés. En effet, selon le ministère de l'éducation et de l'éducation supérieure, $70 \%$ des enfants libanais sont inscrits dans le secteur privé, ce qui représente donc la majeure partie de la population (CRDP, 2018). Parmi les enfants inscrits dans le secteur privé, $52.6 \%$ suivent leur éducation dans des écoles privées payantes, $13.7 \%$ dans des écoles privées gratuites et 3.4\%, dans des écoles privées palestiniennes gratuites. Les écoles publiques sont relativement délaissées par l'État, ce qui fait qu'il existe un décalage important entre l'éducation privée et publique (Frayha, 2009). Cet écart contribue grandement aux inégalités, notamment face à l'afflux de réfugiés syriens qui fréquentent généralement les écoles publiques. De plus, les études nationales ont montré que les étudiants inscrits dans les écoles privées affichaient un taux de réussite nettement plus important aux examens officiels (83.1\%). Ce taux baisse à $64 \%$ pour les étudiants issus des écoles publiques. Les étudiants venant du secteur privé ont bénéficié d'enseignants plus qualifié, outre un risque moindre de redoublement, par comparaison aux enfants inscrits dans les écoles publiques (PNUD Report, 2009). En effet, en 2011, une étude a montré que l'État libanais n'investissait que 1.6\% du PIB national dans l'éducation publique alors que d'autres pays Arabes montraient des taux nettement plus élevés (Soueid et al., 2014).

Bien qu'il n'y ait pas d'études fiables rapportant les différences socio-économiques entre les enfants inscrits dans le secteur privé et ceux inscrits dans le secteur public, il semble que les familles libanaises de niveau socio-économique moyen ou plus inscrivent leurs enfants dans le secteur privé, alors que les plus démunies tendent à fréquenter les écoles publiques (Frayha, 2009). La religion occupe également une place importante dans l'éducation au Liban. Les établissements privés sont dans leurs majorités des écoles catholiques ou musulmanes bien que le Liban compte également des écoles privées laïques (Khalife, 2006). L'enseignement religieux dans les écoles privées se limite à une à deux heures par semaine. Cependant, dans les écoles religieuses privées chrétiennes et musulmanes, les journées commencent souvent par une prière et dans certaines écoles musulmanes, les enfants prient 5 fois par jour (Khalife, 2006).

Roukoz Cynthia $\mid$ Développement des Fonctions Exécutives chez les Enfants 16 


\subsection{Les valeurs libanaises}

Compte tenu de la pluralité des religions au Liban, de la diaspora libanaise assez importante, des nombreux émigrés qui sont revenus résider au Liban, et des systèmes éducatifs hétérogènes à influence occidentales, les Libanais sont considérés comme un peuple Arabe avec un mode de vie assez contemporain et occidental. Cependant, les normes sociales dépendent très largement de la religion et de la région de vie d'une personne. Les valeurs et normes Libanaises sont donc difficiles à spécifier et à généraliser. Pour autant, certaines valeurs sont généralisables et de toutes les valeurs que nous pouvons retrouver dans la société libanaise, c'est surtout le respect de la famille et des parents qui prime. Les valeurs familiales sont très importantes et, comme dans d'autres cultures Arabes, les Libanais vivent dans une collectivité bien plus que dans un individualisme (Buda \& El Sayed-El Khoury, 1998). Il est, par exemple, assez rare de voir un Libanais quitter le foyer familial si ce n'est pour se marier et fonder une famille.

Cette collectivité se retrouve également dans les relations « inter-citoyens ». Cette dernière année, le Liban a été grandement affaibli par une crise socio-économique et politique qui a conduit à la révolution du peuple Libanais contre la classe politique et à de nombreuses manifestations depuis Octobre 2019. Cette situation s'est aggravée par une déflagration, le 4 août 2020, au cœur d'une région densément peuplée de Beirut, qui a causé plus de 300 morts, 5000 blessés et plus de 300 000 sans abris. Cette déflagration a été causé par un incendie dans un entrepôt abritant 2700 tonnes de nitrate d'ammonium au port de Beyrouth, sans mesures de sécurité. Ceci est venu augmenter la colère et la haine du peuple libanais envers la classe politique. Le peuple libanais, connu comme étant "résilient" et "solidaire" s'est donc mobilisé, sans aucune aide financière ni humaine de l'état libanais, pour déblayer les rues, réparer les maisons, abriter des familles, récolter des fonds et des produits alimentaires pour les personnes dans le besoin, et offrir des services médicaux et psychologiques gratuits à l'ensemble de la population. Au Liban, c'est le peuple qui aide le peuple. La population libanaise a entièrement perdu confiance en la classe politique considérée corrompue et criminelle.

Ainsi, le Liban est un pays culturellement riche et hétérogène qui partage une histoire complexe et de nombreux traumas collectifs justifiant des besoins grandissants de services de santé mentale. 


\subsection{La psychologie de l'enfant au Liban}

La pratique de la psychologie au Liban est régie par le ministère de la santé depuis 2017. Le métier de psychologue au Liban exige un niveau d'étude équivalent au Master, ainsi qu'un minimum de 500 heures de stages complétées au cours du cursus de Master et centrées sur une approche clinique déterminée par le maître de stage affilié à l'université.

Au Liban, un psychologue peut recevoir une licence de pratique en Psychologie Clinique ou en Psychologie Scolaire. Étant donné qu'il n'existe pas, à ce jour, de Master spécialisé en Neuropsychologie au Liban, la Neuropsychologie ne fait pas encore partie des pratiques reconnues par l'état libanais. Les psychologues exerçant comme psychologue/neuropsychologues au Liban ont tous complété leurs Master et/ou Doctorat à l'étranger et pratiquent au Liban sous le titre de Psychologue Clinicien.

Les services de psychologie au Liban sont, pour la plupart, assuré par les secteurs privés. La sécurité sociale nationale ne rembourse pas les services psychologiques.

Les psychologues exercent majoritairement dans des centres hospitaliers privés (services de psychiatrie), dans des cliniques externes et au sein de différentes associations privées ou organisations non-gouvernementales (ONG). En effet, dans un pays où le gouvernement n'est pas en mesure d'assurer des services de soins psychologiques et psychiatriques à la population, plusieurs ONG proposent ces services en comptant sur des donations ou des activités de levée de fonds (par exemple, Médecins Sans Frontières, Sesobel, Skoun, Emm El Nour). Il est également très commun de retrouver, au sein même de services hospitaliers privés, des associations qui récoltent des fonds permettant d'assurer les soins psychologiques et psychiatriques aux patients défavorisés (par exemple, Focus Fund, Epsilone).

La réalisation de bilans neuropsychologiques est souvent assurée par des psychologues cliniciens ou des psychologues scolaires, les psychologues/neuropsychologues étant peu nombreux au Liban. Les évaluations cognitives se font souvent au sein de cabinets privés ou de services hospitaliers. Certaines assurances privées remboursent les bilans neuropsychologiques, mais dans la majorité des cas, ce service est autofinancé par le patient ou les familles. Dans le cas où un diagnostic de trouble neurodeveloppemental ou de trouble cognitif acquis est posé chez un enfant, ce dernier est amené à présenter un dossier au ministère des affaires sociales et bénéficiera ainsi d'aides sociales lui permettant d'accéder à certains services d'éducation et de rééducation gratuits 
dans certains centres agréés par l'état. Cependant, ces centres ayant des capacités limitées, les places sont difficiles à trouver, ce qui oblige les familles à rechercher des établissements de soin au sein du secteur privé.

La pratique de la psychologie et de la neuropsychologie de l'enfant au Liban a pris de l'ampleur au cours des dix dernières années. Les demandes d'évaluations neuropsychologiques pour les enfants sont en constante augmentation et viennent souvent du corps enseignant, des parents, des psychiatres ou des neurologues. Cette croissance du nombre de demandes provient d'une prise de conscience quant aux différents troubles d'apprentissages et neurodeveloppementaux dont peut souffrir un enfant. L'inclusion des enfants présentant des troubles neurodeveloppementaux a donc significativement augmenté au cours des dernières années, en particulier dans le secteur privé. Bien que le ministère de l'éducation ait fait des progrès en ce qui concerne l'inclusion d'enfants avec des troubles moteurs ou sensoriels dans les écoles publiques, les enfants présentant des troubles cognitifs ou psychosociaux restent marginalisés et ne reçoivent pas les aménagements nécessaires à leur scolarité au sein des écoles publiques. Cependant, depuis 2017, le droit aux modifications des examens officiels (par exemple, accès à un temps supplémentaire ou à une aide humaine) a été initié par le ministère de l'éducation et est offert à tout enfant portant un diagnostic de trouble neurodeveloppemental confirmé par une visite psychiatrique, ainsi qu'un bilan neuropsychologique administré dans l'un des centres agréés par l'état libanais.

En ce qui concerne l'utilisation de tests psychologiques, la pratique est règlementée par le ministère de la santé et demande à ce que le professionnel dispose d'un titre de psychologue. Les tests utilisés dans la pratique clinique sont pour la plupart des tests Français, Anglais, Américains ou Canadiens, vendus par Liban Test Edition qui a le droit de vente exclusif des éditions PEARSON, ECPA et d'autres maisons d'édition publiant des tests psychologiques. Le test du WISC-IV a été adapté à la langue Arabe et à la population libanaise en 2013 (Touma \& Moussallem, 2016). C'est actuellement le seul test cognitif, utilisé par les psychologues Libanais pour la pratique des bilans psychologiques, adapté chez l'enfant.

Il est également important de prendre en compte l'hétérogénéité des connaissances langagières des enfants libanais, ce qui complique la pratique et oblige souvent le psychologue à modifier la passation standardisée d'un test. Comme mentionné plus haut, bien que la majorité des Libanais soient fluents en Arabe parlé ou dialecte Libanais vernaculaire, ils ne sont pas tous nécessairement

Roukoz Cynthia $\mid$ Développement des Fonctions Exécutives chez les Enfants 19 
fluents en Arabe littéraire ou Arabe Moderne Standard qui est enseigné dans les écoles mais absent des conversations quotidiennes des Libanais. Ainsi, un test présentant des consignes et des items en Arabe Moderne Standard pourrait être difficilement accessible pour certains enfants Libanais ne maitrisant pas cette version de la langue Arabe. De plus, certains Libanais affichent une meilleure maîtrise du Français et/ou de l'Anglais, dans la mesure où ces langues sont majoritairement utilisées dans l'éducation et parfois favorisées par les parents comme mode de communication primaire à la maison. Ainsi, le choix des tests neuropsychologiques utilisés afin de tester un enfant dépend souvent de sa langue de préférence, qui est déterminée durant l'entretien préliminaire avec l'enfant et ses parents. Il est aussi assez commun d'accepter des réponses en différentes langues. Par exemple, à un test de dénomination, un enfant libanais aura tendance à dénommer certains mots en Arabe, d'autres en Français et d'autres encore en Anglais.

En ce qui concerne les normes utilisées, les enfants libanais sont très souvent, voire toujours, comparés à une norme d'enfants étrangers, indépendamment du test utilisé. Ceci est susceptible d'entrainer des biais culturels assez importants, qui sont d'ailleurs mentionnées dans le code d'éthique de l'American Psychological Association (APA), lequel précise que les psychologues se doivent d'interpréter minutieusement les résultats aux tests psychologiques administrés en tenant compte des caractéristiques culturels et linguistiques de la personne évaluée (APA, 2017).

Concernant la recherche, la psychologie de l'enfant étant relativement récente au Liban, les études émergentes dans ce domaine manquent encore dans plusieurs domaines du développement et de la santé mentale de l'enfant. Cependant, les études épidémiologiques montrent une prévalence importante de désordres psychiatriques et psychologiques dans la jeunesse libanaise (Maalouf et al., 2016). Selon une étude épidémiologique menée par Maalouf et al. (2016) auprès de 510 adolescents âgés de 11 à 17 ans, 26.1\% des adolescents souffriraient d'un trouble psychiatrique, les plus communs étant un trouble anxieux (13.1\%) et un trouble déficitaire de l'attention avec ou sans hyperactivité (TDA/H) (10.2\%). Cette prévalence de $26.1 \%$ se montre plus élevée que la prévalence mondiale, estimée à 21\% (Maalouf et al., 2016). Cependant, selon cette étude, seulement $6 \%$ reçoivent ou ont reçu un traitement psychologique et/ou psychiatrique. Vingt-quatre pour cent des parents ont rapporté qu'ils ne traitaient pas le trouble psychiatrique de leur enfant compte tenu des coûts élevés des services de santé mentale au Liban et $26.4 \%$ ont rapporté

Roukoz Cynthia | Développement des Fonctions Exécutives chez les Enfants 20 
l'absence de service de santé mentale à proximité de leur domicile. Cette étude montre ainsi le manque de ressources et de services psychologiques et psychiatriques accessibles à la population libanaise. De plus, des études plus récentes, publiées à la suite de la crise socio-économique et politique que connait le Liban depuis Octobre 2019, ont montré un accroissement considérable du taux d'enfants et d'adolescents souffrant de troubles psychologiques. En effet, selon Baroud et al. (2019), depuis le début de la crise, 6.2\% des enfants libanais souffriraient de symptômes dépressifs et $4.3 \%$ des adolescents montreraient des symptômes dépressifs sévères avec des idées suicidaires.

Les études émergentes dans ce domaine au Liban s'intéressent surtout à l'étude de certains troubles psychiatriques, psychosociaux ou psychopathologiques, avec une majorité des études se focalisant sur les effets des guerres sur la santé mentale des enfants (Itani et al., 2017; Karam et al., 2016). D’un autre côté, très peu d'études locales ont été menées sur le développement cognitif, normal ou pathologique, des enfants libanais, à l'exception de certaines études épidémiologiques étudiant la prévalence du TDA/H auprès des enfants libanais (Maalouf et al., 2016; Richa et al. 2014). Ainsi, parmi les études émergentes dans le domaine de la psychologie de l'enfant durant ces dix dernières années, aucune étude à notre connaissance ne s'est intéressée au développement cognitif et plus particulièrement au développement des FE des enfants libanais. Cependant, les potentielles influences culturelles et contextuelles sur le développement des FE (Chasiotis et al., 2006 ; Lan et al., 2011 ; Oh et al., 2008 ; Sabbagh et al, 2006) permettent de supposer que les données occidentales ne sont pas nécessairement généralisables auprès de la population libanaise. Les particularités contextuelles du Liban pourraient, en effet, influencer le développement des FE. Cependant, une recherche dans les principales bases de données utilisant les mots clefs en Français et Anglais «Libanais », « fonctions exécutives », « enfants » et « développement » n'a montré aucune étude publiée. Il n'existe pas, à ce jour, de calendrier développemental des FE pouvant être appliqué à la population pédiatrique libanaise afin d'affiner les connaissances sur le développement de ces enfants. Pourtant, une meilleure compréhension du développement typique est primordiale afin de mieux comprendre le développement atypique d'un enfant.

Roukoz Cynthia $\mid$ Développement des Fonctions Exécutives chez les Enfants 21 


\section{LES FONCTIONS EXECUTIVES}

\section{La publication suivante est presentée dans ce chapitre:}

Roukoz, C., Er-Rafiqi, M., Le Gall, D., Bellaj, T., \& Roy, A. (2018). A Systematic Review of Cross-cultural Studies on Executive Functions in Children. International Journal of Psychology and Neuroscience, 4(3), 1-31.

\section{En complément à ce chapitre, les publications suivantes ont été publiées en collaboration avec d'autres chercheurs:}

Er-Rafiqi, M., Roukoz, C., Le Gall, D., \& Roy, A. (2018). Fonctions exécutives, environnement et contexte chez l'enfant. In A. Roy, B. Guillery-Girard, G. Aubin \& C. Mayor (Eds.), Neuropsychologie de l'enfant (pp. 169-186). Paris: De Boeck superieur. (Annexe 1)

Er-Rafiqi, M., Roukoz, C., Le Gall, D., \& Roy, A. (2017). Les fonctions exécutives chez l'enfant: développement, influences culturelles et perspectives cliniques. Revue de Neuropsychologie, neurosciences cognitives et cliniques. 9(1), 27-34. (Annexe 2) 


\subsection{Définitions}

Les FE sont définies par Diamond (2013) comme un ensemble de fonctions top-down qui permettent de réaliser des tâches non-routinières quand une réponse automatique ne permet pas d'entreprendre une tâche nouvelle.

Selon les études factorielles menées auprès des adultes (Miyake et al., 2000) et auprès des enfants (Lehto et al., 2003), l'hypothèse de FE plurielles mais interdépendantes prévaut dans la littérature et ces études distinguent généralement la mémoire de travail (MDT), l'inhibition, et la flexibilité mentale comme principales FE. Selon le modèle de développement des FE proposé par Diamond (2013), ces FE permettraient le développement de fonctions de plus haut niveau tel que la planification.

Il est devenu classique de fractionner le processus d'inhibition en plusieurs modalités. Dans son modèle, Diamond (2013) distingue l'inhibition comportementale de l'inhibition cognitive. L'inhibition comportementale permettrait à l'enfant de contrôler ses comportements impulsifs et autoréguler ses réactions émotionnelles et comportementales. D'un autre côté, l'inhibition cognitive permettrait à l'enfant de contrôler voire de supprimer les distracteurs externes ou les représentations mentales intérieures lui permettant de se focaliser sur une tâche scolaire et soutenant ainsi une meilleure attention. Elle permettrait également à l'enfant de supprimer de la MDT les informations inutiles et de permettre un meilleur maintien et manipulation d'informations cibles, rendant les processus d'inhibition et de MDT interdépendants.

La MDT permet le maintien et la manipulation à court terme d'un nombre limité d'informations, le temps d'en permettre le traitement (Baddeley \& Hitch, 1994). La MDT est particulièrement engagée dans la vie quotidienne afin de maintenir une conversation, répondre à des questions, compléter une tâche de calcul mental ou maintenir les informations le temps de résoudre un problème. Selon le modèle de Baddeley \& Hitch, (1994), une composante de la MDT permettrait le maintien et la manipulation des informations verbales, une autre, des informations visuospatiales, et une troisième composante, l'administrateur central, permettrait l'engagement d'autres FE quand cela est nécessaire.

La flexibilité mentale représente une autre composante classique des FE. Elle permet le Roukoz Cynthia | Développement des Fonctions Exécutives chez les Enfants 23 
changement de perspective ou de point de vue, la modification d'une stratégie de résolution de problème quand cette dernière ne permet pas la complétion d'une tâche, ou de « switcher » d'une tâche à une autre et d'éviter des erreurs persévératives. Comme décrit chez l'adulte, Lorena et al. (2013) distinguent, chez l'enfant, la flexibilité réactive de la flexibilité spontanée. La première s'exprime lorsque l'environnement change et exige un changement de réponse afin que cette dernière soit plus adaptée alors que la flexibilité spontanée concerne la production d'un flux d'idées ou de réponses. Selon le modèle de Diamond (2013), la flexibilité mentale se développe grâce à l'évolution des capacités d'inhibition et de MDT, étant donné que trouver de nouvelles stratégies de résolution de problèmes sollicite nos capacités à maintenir en mémoire les stratégies non-fonctionnelles et les inhiber afin de ne pas les reproduire.

Finalement, la planification constitue l'une des FE de haut niveau dont le développement dépend des FE de plus bas niveau: l'inhibition, la MDT, et la flexibilité mentale. La planification permettrait à l'enfant de formuler des hypothèses de résolution de problèmes, de planifier différentes étapes nécessaires à l'atteinte d'un but, d'organiser ses pensées vers un objectif donné, de contrôler l'efficience des procédures engagées, etc.

Ces différentes composantes des FE seraient interdépendantes et ne se développeraient pas de manière synchrone (Davidson et al., 2006 ; Diamond, 2013 ; Garon et al., 2008).

\subsection{Développement des FE}

Le développement des FE dépend de la maturation physiologique du cortex préfrontal et de ses réseaux, incluant la myélinisation. Les FE montrent un développement prolongé en lien avec la maturation étendue des réseaux corticaux qui les sous-tendent. Le développement des FE, bien que prolongé, émerge rapidement, dès les premiers mois de vie, tel que cela a été démontré par Piaget (Piaget, 1964) à travers le paradigme A non B, typiquement réussi par les nourrissons âgés entre 7.5 et 12 mois (Diamond, 1985). Ces mêmes observations ont été notées par Diamond (Diamond et al., 1989) à travers le paradigme du “object retrieval task" dans lequel l'enfant doit atteindre un jouet placé à l'intérieur d'une boîte transparente mais en passant par un côté, droit ou gauche. Ces pics de développement coïncident avec un développement marqué du cortex préfrontal dorsolateral (Koenderink \& Uylings, 1996) et des lésions précoces à ce niveau Roukoz Cynthia | Développement des Fonctions Exécutives chez les Enfants 24 
mèneraient à un échec à ces taches et un ralentissement du développement exécutif ultérieur (Diamond \& Goldman-Rakic, 1989). Les déficits exécutifs observés à long terme ont mené à la notion d'une vulnérabilité précoce des FE chez l'enfant. Ainsi, ces paradigmes ont permis d'observer les premiers signes de développement des FE chez les nourrissons. Le développement des FE serait également particulièrement marqué pendant la période préscolaire (Röthlisberger et al., 2013) et les études montrent une amélioration particulière dans les tâches d'inhibition et de MDT (Diamond, 2013).

Le développement des FE a la particularité d'être précoce mais prolongé jusqu'à l'adolescence voire l'âge adulte (Diamond, 2013). La performance d'enfants aux tâches de MDT verbale et visuospatiale montre une nette amélioration jusqu'à l'adolescence (Best et al., 2009; Gathercole et al. 2004; Luciana et al., 2005). Par exemple, selon Gathercole et al. (2004), les principales composantes de la MDT seraient présentes vers l'âge de 6 ans et une progression des performances sur l'ensemble des tâches de MDT serait notée entre 4 et 15 ans. Une autre étude menée par Egami et al. (2015), impliquant 144 enfants âgés entre 7 et 12 ans et 24 adultes, montre une amélioration rapide et continue des capacités de MDT entre 7 et 10 ans et une amélioration plus lente mais graduelle jusqu'à l'âge de 12 ans.

En ce qui concerne l'inhibition, certaines études supportent l'idée que les capacités d'inhibition se stabiliseraient en début d'âge scolaire (Klenberg et al., 2001; Lehto et al., 2003). Par exemple, Klenberg et al. (2001) ont observé une amélioration jusqu'à l'âge de 6 ans aux tâches de « Statues » et « Knock and Tap game», avec une stablisation à ces épreuves entre 6 et 12 ans. D'un autre côté, d'autres études ont utilisé des tâches d'inhibition plus complexes et ont montré une amélioration plus prolongée des capacités d'inhibition. Par exemple, Brocki et Bohlin (2004) ont observé, à travers une version informatisée du Go No Go test et d'un test d'attention soutenue, une réduction continue du nombre d'erreurs impulsives entre 7, 9 et 11 ans, supportant une amélioration des capacités d'inhibition. D'autres études ont également montré une diminution continue du nombre d'erreurs impulsives à un test informatisé d'attention soutenue après l'âge de 9 ans jusqu'à la fin de l'adolescence (Casey et al., 1997; Jonkman et al., 2003).

Concernant la flexibilité mentale, l'amélioration des capacités de shifting chez l'enfant serait intrinsèquement liée au développement des capacités d'inhibition et de MDT (Best \& Miller,

Roukoz Cynthia $\mid$ Développement des Fonctions Exécutives chez les Enfants 25 
2010). En effet, pour qu'un enfant évite des erreurs persévératives, il lui est nécessaire d'inhiber la réponse automatique non-fonctionnelle et de la garder en mémoire pour quelques secondes, afin de « switcher » vers une réponse plus appropriée. Dans leur étude, Huizinga et al. (2006), à travers 3 tâches informatisées, ont montré un temps de réponse significativement plus rapide chez les enfants âgés de 15 ans par comparaison aux enfants âgés entre 7 et 11 ans. De même, Davidson et al. (2006) ont montré une amélioration continue des capacités de flexibilité mentale entre 4 et 13 ans à des tâches informatisées similaires au Wiscondin Card Sorting Test (WCST). Les capacités de shifting évolueraient graduellement pour atteindre un fonctionnement optimal vers le milieu de l'adolescence (Best \& Miller, 2010).

Enfin, s'agissant de la planification, Luciana et Nelson (1998) ont montré, à travers la tâche de la Tour de Londres impliquant uniquement 2 mouvements, des performances stables entre l'âge de 4 et 8 ans suggérant que la capacité de planifier des séries de 2 à 3 étapes serait présente chez les jeunes enfants en début d'âge scolaire. D'un autre côté, l'utilisation de paradigmes plus complexes de 4 et 5 mouvements a montré des performances stables entre 4 et 8 ans mais significativement meilleures vers la fin de l'adolescence et à l'âge adulte. Ces observations suggèrent que la capacité de planifier des plans complexes de 4 ou 5 étapes émergerait vers l'adolescence. Huizinga et al. (2006) ont également utilisé le test de la Tour de Londres pour montrer des performances émergentes en période scolaire. Celles-ci se développent graduellement pour arriver à un plafond vers l'âge de 15 ans et à une stabilisation à l'âge adulte.

Ainsi, les différentes études mentionnées montrent une progression relativement claire des FE pendant la période scolaire. Cependant, les différentes FE ne se développeraient pas de manière synchrone mais seraient interdépendantes et certaines arriveraient à maturité avant d'autres, soutenant par ailleurs la mise en place des FE de plus haut niveau (Best \& Miller, 2010; Brocki \& Bohlin, 2004; Diamond, 2013 ; Zelazo et al., 2003).

Roukoz Cynthia | Développement des Fonctions Exécutives chez les Enfants 26 


\subsection{Modélisation des FE chez l'enfant}

Il existe à ce jour plusieurs études qui ont débouché sur des modèles de FE ayant ainsi permis une meilleure compréhension des facteurs influençant leur développement.

Parmi les modèles théoriques des FE chez l'enfant, Dennis (2006) propose une modélisation du développement du cortex préfrontal en lien avec les FE. Le cortex préfrontal permettrait, sur un mode top-down, la formation de représentations liées entre elles, permettant l'élaboration d'un plan d'action. Les ressources de traitement rendant possible l'établissement de ces représentations seraient la MDT et le contrôle inhibiteur, sous dépendance des régions frontales dorsolatérales. Le contenu de ces représentations renverrait à des structures de savoir permettant d'assurer un lien temporel, un lien de la pensée et un lien émotionnel. Ainsi, à partir de ces représentations, Dennis (2006) modélise le développement du cortex préfrontal et alloue à ce dernier plusieurs fonctions :

- La planification, la mémoire autobiographique et la mémoire prospective, rattachées au lien temporel.

- La métacognition, la théorie de l'esprit et la résolution de problèmes sociaux, rattachées au lien de la pensée.

- La prise de décision affective, la régulation émotionnelle et la communication des émotions, rattachées au lien émotionnel.

Un autre modèle théorique relativement récent est illustré dans la figure 2 . Il a été proposé par Diamond (2013). C'est un modèle intégratif hiérarchisé qui illustre la dynamique de développement et les interrelations entre plusieurs FE, à savoir la MDT, l'inhibition, la flexibilité mentale et les fonctions de plus haut niveau telles que la planification, la résolution de problème et les aptitudes de raisonnement. Selon ce modèle, les capacités d'inhibition et de MDT émergeraient précocement, dès la période préscolaire, alors que la flexibilité mentale se différencierait des processus précédents plus tardivement, au décours de l'enfance voire pendant l'adolescence. La planification, elle-même tributaire des processus précédents, s'individualiserait encore plus tard. Ainsi, le socle du développement des FE serait constitué des processus d'inhibition et de MDT qui se développeraient relativement tôt dans l'enfance et seraient interdépendants.

Roukoz Cynthia | Développement des Fonctions Exécutives chez les Enfants 27 
Le modèle de Dennis, inspiré de l'adulte, positionne donc le contrôle inhibiteur et la MDT au centre du développement exécutif. Ces processus permettraient d'assurer divers types de liens (lien temporel, lien de la pensée, lien émotionel). Cependant, le modèle de Diamond (2013) est davantage centré sur les quatre processus exécutifs classiquement identifiés chez l'enfant, structuré à travers un développement hiérarchisé et différencié avec l'âge, et des interrelations entre les composantes exécutives. Pour cette raison, le modèle de Diamond (2013) a donc été retenu comme modèle de référence dans ce travail de thèse.

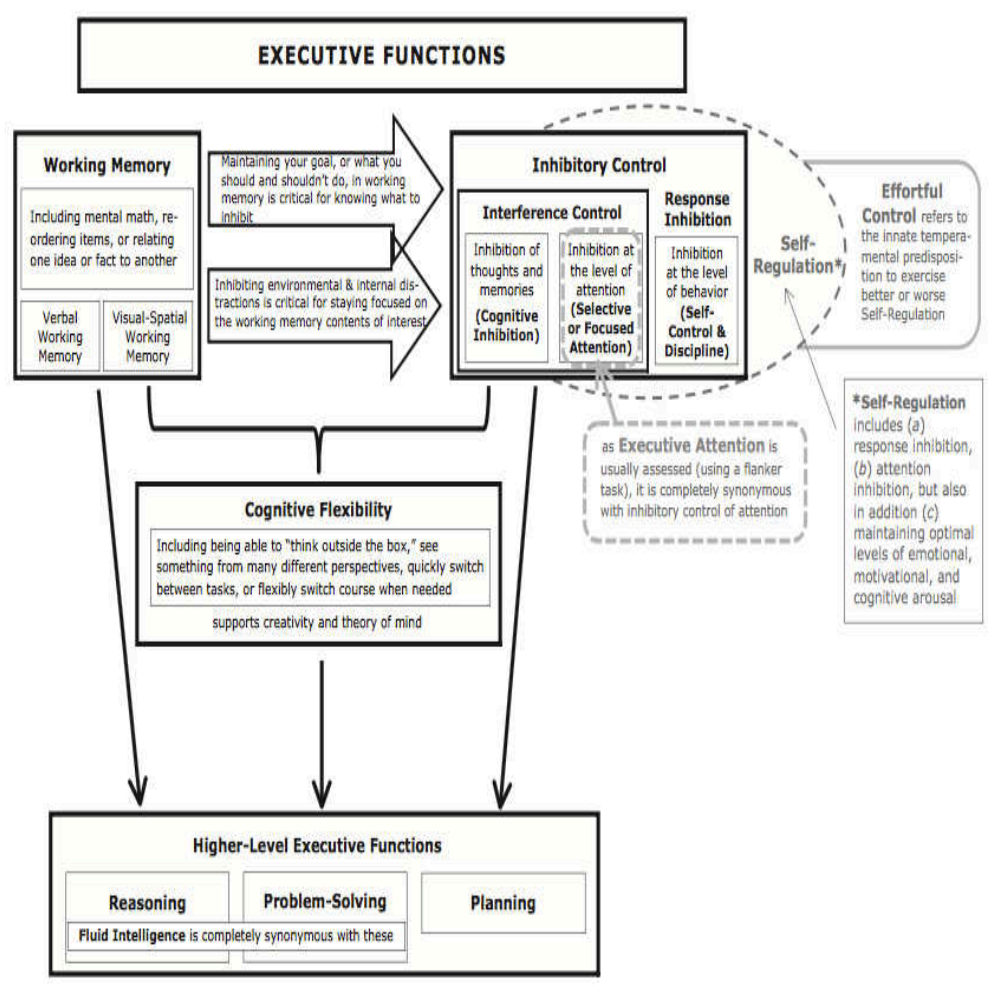

Fig.2 : Modèle de développement des FE de Diamond (2013) montrant une différentiation progressive des processus de MDT, inhibition, flexibilité et FE de haut niveau. Source : Diamond (2013).

D'autres modèles se basant sur des études factorielles ayant comme objectif de dissocier plusieurs FE unitaires ont également été proposés chez l'enfant. Par exemple, Lehto et al. (2003) ont confirmé, chez les enfants âgés de 8 à 13 ans, le modèle initialement proposé par Miyake et al. (2000) chez l'adulte. Ainsi, cette analyse factorielle débouche sur les postulats selon lesquels la Roukoz Cynthia | Développement des Fonctions Exécutives chez les Enfants 28 Libanais @) (1) @ 
flexibilité, la MDT et l'inhibition seraient, chez l'enfant, des composantes exécutives interdépendantes. D’autres études factorielles rejoignent les propositions théoriques de Diamond (2013), suggérant une différentiation graduelle des FE durant la période préscolaire et jusqu'à la période scolaire. Par exemple, les analyses factorielles de Lee et al. (2013) montrent des modèles de FE unitaires avant l'âge de 5 ans, et une émergence de modèles à trois facteurs interdépendants au décours de la période scolaire. Les études factorielles permettent un fractionnement des FE et offrent un angle d'analyse de la structure des FE qui complète l'approche théorique. Cependant, les structures factorielles montrées chez l'enfant diffèrent d'une étude à une autre (par exemple: Brocki \& Bohlin, 2004; Klenberg et al., 2001; Lehto et al., 2003) et ne permettent pas d'aboutir à une structure factorielle consensuelle chez l'enfant. Ceci pourrait s'expliquer par la grande hétérogénéité méthodologique entre les études. Par exemple, l’hétérogénéité au niveau des outils utilisés ou des étendues d'âge dans chaque étude rend la comparaison des facteurs obtenus problématique. De plus, l'effet de l'âge et du niveau socioculturel n'est pas systematiquement contrôlé dans les analyses factorielles. D'ailleurs, une des principales limites des modèles de développement des FE est d'être unidimensionnelle vu qu'elle considère exclusivement la variable âge. En effet, l'âge n'est pas le seul facteur susceptible d'influencer les performances aux tâches exécutives dans le cadre du développement typique. Plusieurs autres facteurs sociodémographiques, tels que le sexe, le niveau socio-économique, le type d'éducation, le bilinguisme ou encore le niveau d'éducation des parents (Ardila et al., 2005; Bellaj et al., 2016; Bialystok \& Viswanathan, 2009) influenceraient le développement des FE.

Quelques études interculturelles montrent une influence importante de la culture des peuples sur le développement des FE chez l'enfant (Bialystok \&Viswanathan, 2009; Sabbagh et al., 2006), même lorsqu'il s'agit de tâches n'impliquant pas de composante verbale de manière prépondérante (Rosselli \& Ardila, 2003). Dans une revue systématique de la littérature, publiée dans le cadre de ce travail de thèse (Roukoz et al., 2018), nous présentons plusieurs études ayant montré des différences significatives au niveau des principales FE (inhibition, MDT et flexibilité mentale) entre les enfants issus de différentes cultures.

Roukoz Cynthia $\mid$ Développement des Fonctions Exécutives chez les Enfants 29 


\title{
3.4. Influences culturelles et sociodémographiques sur le développement des FE
}

\section{La publication suivante est presentée dans ce chapitre:}

Roukoz, C., Er-Rafiqi, M., Le Gall, D., Bellaj, T., \& Roy, A. (2018). A Systematic Review of Cross-cultural Studies on Executive Functions in Children. International Journal of Psychology and Neuroscience, 4(3), 1-31.

\section{A Systematic Review of Cross-cultural Studies on Executive Functions in Children}

\author{
Roukoz, $C^{1}$., Er Rafiqi, $\mathrm{M}^{2}$., Le Gall, D³ ., Bellaj, T., \& Roy, $\mathrm{A}^{2}$. \\ 1. American University of Beirut Medical Center, Lebanon \\ 2. Department of Psychology and Neurology, University Hospital of Angers, France \\ 3. Qatar University, Doha.
}

Correspondent Author: Roukoz Cynthia E-Mail Address: cr21@aub.edu.lb

\begin{abstract}
Background: There is a growing body of literature investigating cross-cultural differences of executive functions in children, most of which suggests potential differences across cultures. This paper systematically reviews the existing literature comparing performance on tasks of executive functions in children emerging from different cultures. Method: PubMed, SAGE, Science Direct, Jstor, Oxford University Press, Psychology \& Behavioral Sciences, Persée, Web of Science, Hypotheses.org, Revues.org, Cairn, and Psycarticles databases were searched to identify articles reporting on crosscultural differences of executive functions in children. Collected data pertinent to the comparison of different cultural groups on one or several tasks of EF in reference to Diamond's model (inhibition, working memory, flexibility, and/or planning) were included. 13 studies were identified. Results: Our review suggests that $84 \%$ of studies conducted on executive functions in children and across cultures show EF differences in one or more EF (inhibition, flexibility, working memory, and planning).

Conclusions: Although the present study is the first study to give an overview of data published on cross-cultural studies on EF in children, there are many limitations to it as we used independent studies using independent tools that are not comparable due to diverse methodological biases. Executive function development in children appears to be heterogeneous across cultures and across subgroups within a given culture. Further cross-cultural studies using comparable tools will lead to a better understanding of the differential and normative developmental trends of executive functions.
\end{abstract}

Keywords: cross-cultural, children, development, executive functions, mental flexibility, working memory, inhibition, planning

Roukoz Cynthia | Développement des Fonctions Exécutives chez les Enfants 30 


\section{Introduction}

EFs (executive functions) can be defined as a set of higher-level cognitive skills that underlie goal-directed behavior (Luria, 1966). They are central processes that play a major role in behavioral self- regulation as well as decision-making. EFs are evoked when a cognitive task requires overriding a response that would have been automatically elicited by the stimulus (Seron, Van der Linden, \& Andrès, 1999). Several factorial studies examined the separation of three often-postulated executive functions (i.e., inhibition control, working memory or information updating and monitoring, and cognitive flexibility), and recognized both the unity and diversity of executive functions (Myake et. al., 2000; Brocki \& Bohlin, 2004). The prefrontal cortex is considered the seat of EFs in the brain. Therefore, EFs continue to develop as the prefrontal cortex continues to mature and develop more connections. Synaptic pruning and myelination of the prefrontal cortex occur at a later stage compared to other areas in the brain and extend into early adulthood. However, despite empirical evidence that shows a late ontogenetic development of EFs in humans, these functions begin to emerge in newborns as young as 1 month old. Several authors discussed a non-linear and non- synchronous development of core EFs in children (e.g., Dennis, 2006; Diamond, 2013). Inhibitory control and working memory emerge in infancy whereas cognitive flexibility would emerge later if working memory and inhibitory control are operant. When inhibitory control, working memory and cognitive flexibility become efficient, higher-level EFs such as reasoning, problem solving, and planning, would start to emerge.

Nonetheless, there exist variations in the development of EFs as several cultural and individual-dependent factors could interfere in the development of EFs in humans. Studies this past decade have questioned cross-cultural differences in EFs development as well as individual- dependent factors that can interfere with EFs. According to Rabbit (1997), the first and most important characteristic of EFs is dealing with novelty. Rabbit (1997) postulated that executive control is necessary to deal with novel tasks and is not engaged when automatic and known tasks are performed. Taking into consideration this definition, EFs is best conceptualized as an experience-dependent function since it relies on personal experiences. In fact, in the past decade, various studies on EFs emphasized on defining the environmental and cultural factors that could determine EFs development. A child's interactions with his peers and parents, his or her language proficiency, the educational setting, or even the number of siblings in a family could potentially impact the development of EFs in children. Several studies showed a potential impact of individual sociodemographic factors on the development of EFs. Among the investigated factors are gender (Becker, Isaac, \& Hynd, 1987; Berlin \& Bohlin, 2002), language proficiency (Pena, Bedore, \& Zlatic-Giunta, 2002), type of school attended (private or public) (Ardila, Rosselli, Matute, \& Guajardo, 2005), or socio-economic status (ArànFilippetti \& Richaud De Minzi, 2012; Ardila, Rosselli, Matute, \& Guajardo, 2005; Hoff et al., 2003; Kohen et al., 2002).

For instance, the effect of gender on cognitive development is largely investigated but findings remain inconclusive and no consensus is reached regarding whether one gender shows

Roukoz Cynthia | Développement des Fonctions Exécutives chez les Enfants 31 
better cognitive performance than the other. Several authors report findings of more efficient cognitive development in girls (Ardila et al., 2005) whereas others report better cognitive functions in boys (Halpern, 2000). In addition, some studies showed a significant interaction between gender and culture. For instance, one study showed that Russian girls performed better than Russian boys on a task of visuo-spatial working memory whereas boys from Kirghizstan in Central Asia performed better than girls on the same task (Ismatullina et. al., 2014). The authors suggested that the deferential influence of gender on working memory performance could be culture-dependent.

Another related factor is bilingualism. Bilingualism is defined as the use of two languages by an individual and was also shown to play a role in the development of EFs. For example, a study showed that American bilingual children perform better than monolingual children on tasks of inhibition (Carlson \& Meltzoff, 2008). Another study was conducted on Indian and Canadian bilingual school aged children and showed that bilingualism affected the development of inhibitory control and cognitive flexibility (Bialystok \& Viswanathan, 2009). The study showed that bilinguals performed better on those tasks compared to monolinguals.

Similarly to bilingualism, the type of school attended (private or public) and the level of parental education also showed to have a significant influence on the development of EFs on children. A study conducted on American school aged children show a variable effect of parental level of education on children's performance on problem solving tasks and tasks requiring cognitive flexibility, and a strong effect of the type of school attended (Ardila et al., 2005). However, those findings were partially contradicted by Bellaj, Salhi, Le Gall and Roy (2015) as the authors did not report a relationship between parental level of education on children's EFs. However, they found one particular interaction between paternal level of education and certain specific measures such as time to complete a task of inhibition and digit span backward.

In addition to socio-demographic variables, studies showed that parent-child relationship also plays a significant role in the development of self-control in children. A study by Bernier, Carlson, and Whipple (2010) showed that promoting autonomy in children was the strongest predictor of EFs performance at every age, independently of intellectual functioning of the child and maternal level of education. Also, in one study, Rhodes et al. (2011) found that parenting styles, including the type of interaction between a mother and her child can affect significantly the performance of EFs in children as young as 36 months old.

Despite the growing body of literature on the significant effect of sociodemographic factors and cultural environment on the development of a child's abilities, the impact of the environment on EFs in children remains understudied and the body of literature available to date is insufficient to understand how such factors interact with EFs. Moreover, the theoretical models available to date do not take into consideration the predictive effect of the environment and culture on EFs, which allows us to question the validity of these models and consequently raise concerns regarding their generalizability across different contexts. Until today, several environmental contexts remain unexplored and cross-cultural studies are of primary

Roukoz Cynthia | Développement des Fonctions Exécutives chez les Enfants 32 
importance to understand the development of EFs in children and highlight cross- cultural differences and invariance of EFs across cultures.

The first purpose of the current study is to review previous research conducted on crosscultural differences of EFs in pre-school and school aged children emerging from different cultural backgrounds. The review of literature will highlight the importance of culture and sociodemographic individual factors, in the development of EFs. The second purpose of the study is to evaluate the use of assessment instruments across different cultural settings. Differences in performance on tasks measuring cognitive abilities across populations of different cultures raises concerns over the validity of the evaluation and questions the universal aspect of neuropsychological evaluations (Bellaj \& Seron, 2014). This review aims to emphasize the importance of adapting instruments for different cultures. In fact, a study conducted across 10 different countries on individuals between the ages of 15 and 83 showed that an individual's scores could indicate impaired abilities if the scores are being compared to an established norm of a neighboring country (Fernandez \& Marcopulos, 2008). For example, on the Trail Making Test (TMT) Part B, Canadians of ages 20-29 years complete the task in, on average, 85.7 seconds, whereas Chinese individuals of the same age complete it in 44.7 seconds. The authors showed that norms of different cultures for such a simple task are not interchangeable despite the fact that some cultures share common habits and customs. Byrne et al. (2009) also emphasize on the importance of psychological construct in several cultures. When a psychological construct is measured in a cultural group, the meaning of the construct might be different in another culture. The instruments must therefore be adapted to the relevant culture by taking into consideration the equivalence of construct.

In this review, we will consider the core EFs of Diamond's model of EFs (Diamond, 2013), which are inhibitory control, working memory, cognitive flexibility and planning. In the first section, we will detail the methodology used to search for relevant articles. Next, findings are presented and then discussed.

\section{Method}

Studies related to cross-cultural studies of EFs in children were reviewed. Several scientific databases (PubMed, SAGE, Science Direct, Jstor, Oxford University Press, Psychology $\&$ Behavioral Sciences, Persée, Web of Science, Hypotheses.org, Revues.org, Cairn and Psycarticles) were searched for relevant literature relating to cross-cultural comparison of EFs among children. Three sets of search words were entered. At first, the keywords « cross-cultural », «EF», and « children » were used together. Two authors of the current study (M.E and C.R) conducted the initial search and each of them reviewed six of the mentioned databases. This narrows the room for error by having two independent searches by two different researchers. After examining the retrieved studies, a second search was conducted by one of the authors (M.E). The second search included the words in English and French " working memory », " inhibition », « flexibility », « planning », « inhibitory control », « response suppression», « switching », « shifting », « attentional control », « self-monitoring », « organization », « updating », « monitoring», « problem solving », « interference control », « cognitive control », and « self-

Roukoz Cynthia | Développement des Fonctions Exécutives chez les Enfants 33 
control », each associated to the words « cross-cultural » and " children». A total of 496,460 studies were found by our databases. Since our databases targeted all inserted words individually, a very large number of studies, which were not relevant to the current study, were found. Therefore, the first 200 articles of each database were reviewed by evaluating their titles and abstracts. First two authors (M.E and C.R) reviewed the abstracts of the studies, and included the articles depending on their relevance to our study. Studies were included if they were related to cross- cultural comparison of EF between different countries or subcultural comparison among different populations from a same country. Only studies that collected data pertinent to the comparison of different cultural groups on one or several tasks of EFs (inhibition, working memory, flexibility, and/or planning) were included. Studies related to cross-cultural validation of a tool in different languages were excluded since they did not directly compare different cultures on psychological test measures. Studies related to cross-cultural differences of theory of mind or other functions different than the mentioned above were excluded as well. Finally, studies that conducted indirect comparison of EFs (e.g. comparing the relationship between EF and academic achievement to understand whether this association is universal or not) were excluded as well. Consequently, 16 studies were included and read by both authors (M.E and C.R) and 13 were selected based on their content. Reference lists of the 13 articles were then reviewed to find additional researches relevant to our study. No additional studies were included after reviewing references. The 13 selected articles were read for review and analysis and the first author (C.R.) classified the relevant results of each study in tables that were reviewed by the second author (M.E). The main relevant information was included in Table 1 with an emphasis on the cross-cultural differences established between groups. Table 1 include the following variables: age and gender of the children, sample size, cultures compared, variables, EF tools used, and relevant results. 


\section{Results}

\section{Table 1: An overview of studies on cross-cultural comparison of EF in children}

\begin{tabular}{|c|c|c|c|c|c|c|c|c|}
\hline Reference & Sample & $\begin{array}{l}\text { Cultures } \\
\text { included }\end{array}$ & $\begin{array}{l}\text { Variables } \\
\text { studied }\end{array}$ & $\begin{array}{l}\text { Sociodemograp } \\
\text { hic variables }\end{array}$ & $\begin{array}{l}\text { Tools used to } \\
\text { assess EF }\end{array}$ & $\begin{array}{l}\text { Test } \\
\text { adaptati } \\
\text { on } \\
\text { yes/no }\end{array}$ & $\begin{array}{l}\text { Relevant } \\
\text { results }\end{array}$ & $\begin{array}{l}\text { Cross } \\
\text { cultur } \\
\text { al } \\
\text { differ } \\
\text { ences }\end{array}$ \\
\hline $\begin{array}{l}\text { 1. Sabbagh, } \\
\text { M. A., Xu, } \\
\text { F., Carlson, } \\
\text { S. M., } \\
\text { Moses, L. } \\
\text { J., \& Lee, } \\
\text { K. (2006) }\end{array}$ & $\begin{array}{l}\text { Preschoolers } \\
\text { 109 Chinese: } \\
\text { Age: } 36 \text { to } 59 \\
\text { months } \\
\text { Gender: } 50 \\
\text { girls } \\
107 \text { US: } \\
\text { Age: } 36 \text { to } 59 \\
\text { months } \\
\text { Gender: } 56 \\
\text { girls }\end{array}$ & $\begin{array}{l}\text { Chinese } \\
\text { Americans }\end{array}$ & $\begin{array}{l}\text { Theory of } \\
\text { mind } \\
\text { Inhibition } \\
\text { Flexibility } \\
\text { Impulsivity } \\
\text { Culture } \\
\text { Age }\end{array}$ & $\begin{array}{l}\text { Age studied } \\
\text { Gender } \\
\text { controlled } \\
\text { Considered all } \\
\text { middle-class but } \\
\text { no systematic } \\
\text { demographic } \\
\text { data was } \\
\text { collected. }\end{array}$ & $\begin{array}{l}\text { Inhibition: } \\
\text { Day/Night Stroop } \\
\text { Task } \\
\text { Grass/Snow Stroop } \\
\text { Task } \\
\text { Bear/Dragon Task } \\
\text { Tower-Building } \\
\text { Task } \\
\text { Whisper Task } \\
\text { Impulsivity: } \\
\text { Kansas Reflection- } \\
\text { Impulsivity Scale } \\
\text { for Preschoolers } \\
\\
\text { Flexibility: } \\
\text { Dimensional- } \\
\text { Change Card } \\
\text { Sorting test }\end{array}$ & yes & $\begin{array}{l}\text { Chinese }> \\
\text { Americans on } \\
\text { all measures of } \\
\text { executive } \\
\text { functioning }\end{array}$ & Yes \\
\hline $\begin{array}{l}2 . \\
\text { Chasiotis, } \\
\text { A. (2006) }\end{array}$ & $\begin{array}{l}\text { Preschoolers } \\
\text {-116 German: } \\
\text { Age: } 39 \text { to } 58 \\
\text { months. } \\
\text { Gender: } 63 \\
\text { girls } \\
\text { - } 82 \text { Costa } \\
\text { Rican: } \\
\text { Age: } 39 \text { to } 57 \\
\text { months } \\
\text { Gender: } 36 \\
\text { girls } \\
\text {-116 } \\
\text { Cameroonian: } \\
\text { Age: } 36 \text { to } 60 \\
\text { months } \\
\text { Gender: } 55 \\
\text { girls }\end{array}$ & $\begin{array}{l}\text { German } \\
\text { Costa } \\
\text { Rican } \\
\text { Cameroon } \\
\text { ian }\end{array}$ & $\begin{array}{l}\text { Theory of } \\
\text { mind } \\
\text { Inhibitory } \\
\text { control } \\
\text { Culture }\end{array}$ & $\begin{array}{l}\text { Age controlled } \\
\text { Gender } \\
\text { controlled } \\
\text { Number of } \\
\text { siblings } \\
\text { controlled } \\
\text { language } \\
\text { understanding } \\
\text { controlled } \\
\text { mother's } \\
\text { education } \\
\text { controlled }\end{array}$ & $\begin{array}{l}\text { Conflict tasks: } \\
\text { Bear \& Dragon } \\
\text { Hand game } \\
\text { Day \& night task } \\
\text { Delay tasks: } \\
\text { Snack delay } \\
\text { Gift delay }\end{array}$ & no & $\begin{array}{l}\text { German }= \\
\text { Costa Rican } \\
\text { children on all } \\
\text { tasks } \\
\text { German and } \\
\text { Costa Rican > } \\
\text { Cameroonian } \\
\text { in conflict } \\
\text { inhibition } \\
\text { Cameroonian } \\
> \\
\text { German and } \\
\text { Costa Rican in } \\
\text { delay } \\
\text { inhibition. }\end{array}$ & Yes \\
\hline
\end{tabular}




\begin{tabular}{|c|c|c|c|c|c|c|c|c|}
\hline $\begin{array}{l}\text { 3. Rubin, } \\
\text { K. H. } \\
\text { (2006) }\end{array}$ & 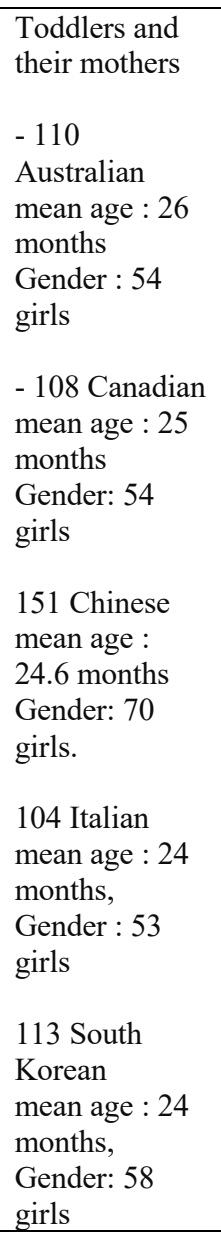 & $\begin{array}{l}\text { Australian } \\
\text { Canadian } \\
\text { Chinese } \\
\text { Italian } \\
\text { South } \\
\text { Korean }\end{array}$ & $\begin{array}{l}\text { Behavioral } \\
\text { inhibition. } \\
\text { Culture } \\
\text { Gender }\end{array}$ & $\begin{array}{l}\text { Gender studied } \\
\text { Age controlled }\end{array}$ & $\begin{array}{l}\text { observation during a } \\
\text { structured } \\
\text { observational } \\
\text { laboratory session }\end{array}$ & no & $\begin{array}{l}\text { Italian and } \\
\text { Australian }< \\
\text { Chinese and } \\
\text { South Korean }\end{array}$ & Yes \\
\hline $\begin{array}{l}\text { 4. Oh, S., } \\
\text { \& Lewis, } \\
\text { C. (2008) }\end{array}$ & $\begin{array}{l}\text { Preschoolers } \\
\text { Study 1: } 40 \\
\text { Korean, } \\
3.5-4 \text { years old } \\
22 \text { girls } \\
\text { Study 2: } \\
76 \text { Korean, } \\
37 \text { girls versus } \\
64 \text { English, } 35 \\
\text { girls } \\
\\
\text { Study } 2: 4 \\
\text { groups : } \\
-3 \text { years old: } 20 \\
\text { Korean, } 14 \\
\text { English. } \\
-3.5 \text { years old: } \\
17 \text { Korean, } 19 \\
\text { English. } \\
-4 \text { years old: } 22 \\
\text { Korean, } 15 \\
\text { English. } \\
-4.5 \text { years old: } \\
17 \text { Korean, } 16 \\
\text { English. }\end{array}$ & $\begin{array}{l}\text { Korean } \\
\text { British }\end{array}$ & $\begin{array}{l}\text { Inhibition } \\
\text { Switching } \\
\text { Working } \\
\text { memory } \\
\text { Mental state } \\
\text { Culture } \\
\text { Age }\end{array}$ & Age studied & $\begin{array}{l}\text { Conflict inhibition: } \\
\text { Day/night task } \\
\text { Luria's hand game } \\
\\
\text { Delay inhibition: } \\
\text { Tower-building task } \\
\text { Self-control task } \\
\text { Working memory: } \\
\text { Finger tapping and } \\
\text { labeling trials } \\
\text { Eight boxes } \\
\text { scrambled test } \\
\text { Backward word } \\
\text { span task. } \\
\text { Switching: } \\
\text { Dimensional- } \\
\text { Change Card } \\
\text { Sorting test }\end{array}$ & no & $\begin{array}{l}\text { Korean }> \\
\text { British on tasks } \\
\text { of inhibitory } \\
\text { control, } \\
\text { working } \\
\text { memory, and } \\
\text { switching. } \\
\text { Associations } \\
\text { between } \\
\text { individual } \\
\text { measures of } \\
\text { inhibition, } \\
\text { working } \\
\text { memory and } \\
\text { switching were } \\
\text { different across } \\
\text { both cultures. } \\
\text { British }> \\
\text { Korean on the } \\
\text { association } \\
\text { between EF } \\
\text { and mental } \\
\text { state } \\
\text { understanding. }\end{array}$ & Yes \\
\hline
\end{tabular}




\begin{tabular}{|c|c|c|c|c|c|c|c|c|}
\hline $\begin{array}{l}5 . \\
\text { Bialystok, } \\
\text { E., \& } \\
\text { Viswanatha } \\
\text { n, M. } \\
(2009)\end{array}$ & $\begin{array}{l}\begin{array}{l}\text { School-aged } \\
\text { children }\end{array} \\
30 \text { Canadian } \\
\text { monolinguals, } \\
15 \text { girls } \\
30 \text { Canadian } \\
\text { bilinguals, } 15 \\
\text { girls } \\
30 \text { Indian } \\
\text { bilinguals, } 18 \\
\text { girls. } \\
\text { Mean age : } 8.5\end{array}$ & $\begin{array}{l}\text { Canadian } \\
\text { Indian }\end{array}$ & $\begin{array}{l}\text { Response } \\
\text { Suppression } \\
\text { Inhibitory } \\
\text { Control } \\
\text { Cognitive } \\
\text { Flexibility } \\
\text { Culture } \\
\text { Language } \\
\text { Proficiency }\end{array}$ & $\begin{array}{l}\text { Language } \\
\text { proficiency } \\
\text { (bilingual, } \\
\text { monolingual) } \\
\text { studied } \\
\text { Age controlled } \\
\text { Gender } \\
\text { controlled }\end{array}$ & $\begin{array}{l}\text { flexibility, } \\
\text { inhibition, and } \\
\text { response } \\
\text { suppression: } \\
\text { Face Task } \\
\text { Background } \\
\text { measures : } \\
\text { *Short-term verbal } \\
\text { memory : } \\
\text { Animal span task } \\
\text { *Working } \\
\text { Memory: } \\
\text { Sequencing span } \\
\text { task } \\
\text { *Spatial Memory : } \\
\text { Corsi blocks } \\
\text { *Flexibility : } \\
\text { Trail-making task }\end{array}$ & no & $\begin{array}{l}\text { Canadian and } \\
\text { Indian } \\
\text { bilinguals > } \\
\text { Canadian and } \\
\text { Indian } \\
\text { monolingual } \\
\text { on tasks of } \\
\text { inhibitory } \\
\text { control and } \\
\text { cognitive } \\
\text { flexibility. } \\
\text { Canadian and } \\
\text { Indian } \\
\text { bilinguals = } \\
\text { Canadian and } \\
\text { Indian } \\
\text { monolingual in } \\
\text { response } \\
\text { suppression } \\
\text { and on a } \\
\text { control } \\
\text { condition that } \\
\text { did not involve } \\
\text { executive } \\
\text { control. } \\
\text { Canadian } \\
\text { bilinguals = } \\
\text { Indian } \\
\text { bilinguals. } \\
\text { Canadian } \\
\text { monolingual = } \\
\text { Indian } \\
\text { monolingual } \\
\text { on all } \\
\text { measures. }\end{array}$ & No \\
\hline $\begin{array}{l}\text { 6. Lahat, } \\
\text { A., Todd, } \\
\text { R. M., } \\
\text { Mahy, C. } \\
\text { E. M., Lau, } \\
\text { K., Zelazo, } \\
\text { P. D. } \\
\text { (2010). }\end{array}$ & $\begin{array}{l}\text { Pre-schoolers } \\
\\
37 \text { English- } \\
\text { speaking } \\
\text { (Mean age = } \\
5.28 \text { years, (11 } \\
\text { girls) from a } \\
\text { European- } \\
\text { Canadian } \\
\text { background } \\
17 \text { children (12 } \\
\text { girls) from a } \\
\text { Chinese- } \\
\text { Canadian } \\
\text { background } \\
\text { (Mean age = } \\
5.18 \text { years) }\end{array}$ & $\begin{array}{l}\text { ChineseCa } \\
\text { nadian } \\
\text { European- } \\
\text { Canadian }\end{array}$ & Inhibition & $\begin{array}{l}\text { Groups did not } \\
\text { differ in age } \\
\text { Groups did not } \\
\text { differ in gender } \\
\text { Both groups } \\
\text { were second- } \\
\text { generation } \\
\text { immigrants. } \\
\text { No significant } \\
\text { differences were } \\
\text { found between } \\
\text { groups on a } \\
\text { collectivism and } \\
\text { individualism } \\
\text { questionnaire }\end{array}$ & $\begin{array}{l}\text { Inhibition: } \\
\text { Go/no-go task, } \\
\text { during which high- } \\
\text { density } \\
\text { electroencephalogra } \\
\text { phic (EEG) data } \\
\text { were recorded. }\end{array}$ & Yes & $\begin{array}{l}\text { Chinese- } \\
\text { canadian = } \\
\text { Europeam- } \\
\text { canadian in } \\
\text { children's } \\
\text { behavioral } \\
\text { performance } \\
\text { on the task } \\
\\
\text { Chinese- } \\
\text { Canadian } \\
\text { children } \\
\text { showed more } \\
\text { activation in } \\
\text { dorsomedial, } \\
\text { ventromedial, } \\
\text { and (bilateral) } \\
\text { ventrolateral } \\
\text { prefrontal } \\
\text { cortex. }\end{array}$ & Yes \\
\hline
\end{tabular}




\begin{tabular}{|c|c|c|c|c|c|c|c|c|}
\hline $\begin{array}{l}\text { 7. Lan, X., } \\
\text { Legare, C. } \\
\text { H., Ponitz, } \\
\text { C. C., Li, } \\
\text { S., \& } \\
\text { Morrison, } \\
\text { F. J. } \\
\text { (2011). }\end{array}$ & 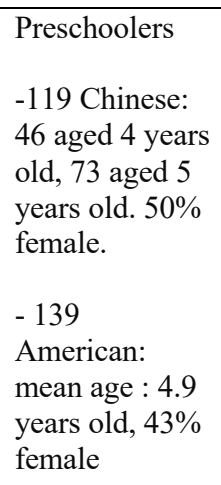 & $\begin{array}{l}\text { Chinese } \\
\text { Americans }\end{array}$ & $\begin{array}{l}\text { Inhibition } \\
\text { Working } \\
\text { Memory } \\
\text { Attentional } \\
\text { Control } \\
\text { Academic } \\
\text { Achievemen } \\
\text { ts } \\
\text { Culture }\end{array}$ & $\begin{array}{l}\text { Gender } \\
\text { controlled } \\
\text { Age controlled }\end{array}$ & $\begin{array}{l}\text { Inhibition: } \\
\text { Head-Toes-Knees- } \\
\text { Shoulders (HTKS) } \\
\text { task } \\
\text { Working memory: } \\
\text { the Sentence } \\
\text { Completion task } \\
\text { Attentional } \\
\text { control task: } \\
\text { The Woodcock- } \\
\text { Johnson Pair } \\
\text { Cancellation task }\end{array}$ & yes & $\begin{array}{l}\text { Chinese }> \\
\text { American on } \\
\text { inhibition and } \\
\text { attentional } \\
\text { control tasks. }\end{array}$ & Yes \\
\hline $\begin{array}{l}8 . \\
\text { Moriguchi, } \\
\text { Y., Evans, } \\
\text { A. D., } \\
\text { Hiraki, K., } \\
\text { Itakura, S., } \\
\text { \& Lee, K. } \\
\text { (2012a) }\end{array}$ & $\begin{array}{l}\text { Canadian } \\
\text { preschoolers: } \\
38 \text { children: } 3 \\
\text { years old (25 } \\
\text { boys, } 13 \text { girls), } \\
32 \text { children : } 4 \\
\text { year old (12 } \\
\text { boys, } 20 \text { girls). } \\
\text { Japanese } \\
\text { preschoolers : } \\
34 \text { children : } 3 \\
\text { years old (12 } \\
\text { boys, } 22 \text { girls), } \\
27 \text { children : } 4 \\
\text { years old (13 } \\
\text { boys, } 14 \text { girls). }\end{array}$ & $\begin{array}{l}\text { Canadian } \\
\text { Japanese }\end{array}$ & $\begin{array}{l}\text { Culture } \\
\text { Cognitive } \\
\text { shifting } \\
\text { Age }\end{array}$ & $\begin{array}{l}\text { Age studied } \\
\text { Gender } \\
\text { controlled }\end{array}$ & $\begin{array}{l}\text { Shifting: } \\
\text { Standard } \\
\text { Dimensional- } \\
\text { Change Card } \\
\text { Sorting test } \\
\text { Social Dimensional- } \\
\text { Change Card } \\
\text { Sorting test }\end{array}$ & no & $\begin{array}{l}\text { Canadian = } \\
\text { Japanese on } \\
\text { Standard } \\
\text { DCCS } \\
\text { Canadian > } \\
\text { Japanese on } \\
\text { social DCCS }\end{array}$ & No \\
\hline $\begin{array}{l}\text { 9. Imada, } \\
\text { T., Carlson, } \\
\text { S. M., \& } \\
\text { Itakura, S. } \\
\text { (2013) }\end{array}$ & $\begin{array}{l}89 \text { caucasian } \\
\text { american } \\
\\
86 \text { japanese } \\
\text { typically } \\
\text { developing } \\
\text { children } \\
\text { Age range : 4-9 } \\
\mathrm{N}=175 \\
3 \text { groups : } \\
\text { 4-5 years old: } \\
\text { 30 American } \\
\text { (13 girls) and } \\
\text { 30 Japanese } \\
\text { (14 girls). } \\
\text { 6-7 years old: } \\
\text { 30 American } \\
\text { (13 girls) and } \\
\text { 28 Japanese } \\
\text { (13 girls). } \\
\text { 8-9 years old: } \\
\text { 29 American } \\
\text { (17 girls) and } \\
\text { 28 Japanese } \\
\text { (15 girls). }\end{array}$ & $\begin{array}{l}\text { Americans } \\
\text { Japanese }\end{array}$ & $\begin{array}{l}\text { Culture } \\
\text { Context } \\
\text { sensitivity } \\
\text { Set shifting } \\
\text { Age }\end{array}$ & Age studied & $\begin{array}{l}\text { Shifting: } \\
\text { Dimensional- } \\
\text { Change Card } \\
\text { Sorting test } \\
\text { Delay task: } \\
\text { Gift Delay }\end{array}$ & no & $\begin{array}{l}\text { Japanese }> \\
\text { Americans on } \\
\text { set-shifting } \\
\text { executive } \\
\text { function task } \\
\text { Japanese > } \\
\text { American on } \\
\text { measure of } \\
\text { context- } \\
\text { sensitivity }\end{array}$ & Yes \\
\hline
\end{tabular}




\begin{tabular}{|c|c|c|c|c|c|c|c|c|}
\hline $\begin{array}{l}\text { 10. Thorell, } \\
\text { L. B., } \\
\text { Veleiro, A., } \\
\text { Siu, A. F. } \\
\text { Y., \& } \\
\text { Mohamma } \\
\text { di, H. } \\
\text { (2013a) }\end{array}$ & $\begin{array}{l}\text { Children from } \\
4 \text { different } \\
\text { countries: } \\
\text { Sweden: } \\
\text { n=141, mean } \\
\text { age: } 102 \\
\text { months, } 71 \\
\text { girls. } \\
\text {-Spain: } \mathrm{n}=219 \text {, } \\
\text { mean age : } 99 \\
\text { months, } 113 \\
\text { girls. } \\
\text { China, } \mathrm{n}=72 \text {, } \\
\text { mean age: } 106 \\
\text { months, } 34 \\
\text { girls. } \\
\text {-and Iran, } \\
\mathrm{n}=49 \text {, mean } \\
\text { age: } 104 \\
\text { months, } 25 \\
\text { girls. } \\
\text { Age range : 6- } \\
11\end{array}$ & $\begin{array}{l}\text { Swedish } \\
\text { Spanish } \\
\text { Chinese } \\
\text { Iranian }\end{array}$ & $\begin{array}{l}\text { Culture } \\
\text { working } \\
\text { memory } \\
\text { inhibition } \\
\text { gender }\end{array}$ & $\begin{array}{l}\text { Age controlled } \\
\text { Gender studied }\end{array}$ & $\begin{array}{l}\text { Inhibition and } \\
\text { Working memory: } \\
\text { Childhood } \\
\text { Executive } \\
\text { Functioning } \\
\text { Inventory (CHEXI) }\end{array}$ & yes & $\begin{array}{l}\text { Iranian }> \\
\text { Chinese on } \\
\text { symptom } \\
\text { ratings of } \\
\text { working } \\
\text { memory } \\
\text { impairments. } \\
\text { Chinese < } \\
\text { Swedish, } \\
\text { Spanish, } \\
\text { Iranians on } \\
\text { teacher ratings } \\
\text { of the CHEXI. } \\
\text { Swedish > } \\
\text { Spanish, } \\
\text { Chinese, } \\
\text { Iranian on } \\
\text { parent ratings } \\
\text { of the CHEXI. } \\
\text { Swedish, } \\
\text { Spanish, and } \\
\text { Chinese boys < } \\
\text { Swedish, } \\
\text { Spanish, and } \\
\text { Chinese girls } \\
\text { on most EF } \\
\text { measures. } \\
\text { Iranian boys }> \\
\text { Iranian girls on } \\
\text { measures of } \\
\text { the parent } \\
\text { version of the } \\
\text { CHEXI. }\end{array}$ & Yes \\
\hline $\begin{array}{l}11 . \\
\text { Ismatullina, } \\
\text { V., } \\
\text { Voronin, I., } \\
\text { Shelemetie } \\
\text { va, A., \& } \\
\text { Malykh, S. } \\
(2014)\end{array}$ & $\begin{array}{l}289 \\
\text { adolescents : } \\
172 \text { from } \\
\text { Kyrgyzstan } \\
\text { and } 117 \text { from } \\
\text { Russia } \\
\text { Mean age } 12.9\end{array}$ & $\begin{array}{l}\text { Kyrgyz } \\
\text { Russian }\end{array}$ & $\begin{array}{l}\text { Culture } \\
\text { Working } \\
\text { memory } \\
\text { Age } \\
\text { Gender }\end{array}$ & $\begin{array}{l}\text { Age studied } \\
\text { Gender studied }\end{array}$ & $\begin{array}{l}\text { Spatial Working } \\
\text { memory: } \\
\text { Spatial Working } \\
\text { Memory task from } \\
\text { the CANTAB } \\
\text { battery }\end{array}$ & No & $\begin{array}{l}\text { Kyrgiz }= \\
\text { Russian } \\
\text { on working } \\
\text { memory } \\
\text { measures. } \\
\text { Significant } \\
\text { gender-by- } \\
\text { country } \\
\text { interaction : } \\
\text { *Kyrgyz males } \\
>\text { Kyrgiz } \\
\text { females in the } \\
\text { spatial working } \\
\text { memory task } \\
\text { *Russian } \\
\text { males }< \\
\text { Russian } \\
\text { females in the } \\
\text { spatial working } \\
\text { memory task }\end{array}$ & Yes \\
\hline
\end{tabular}




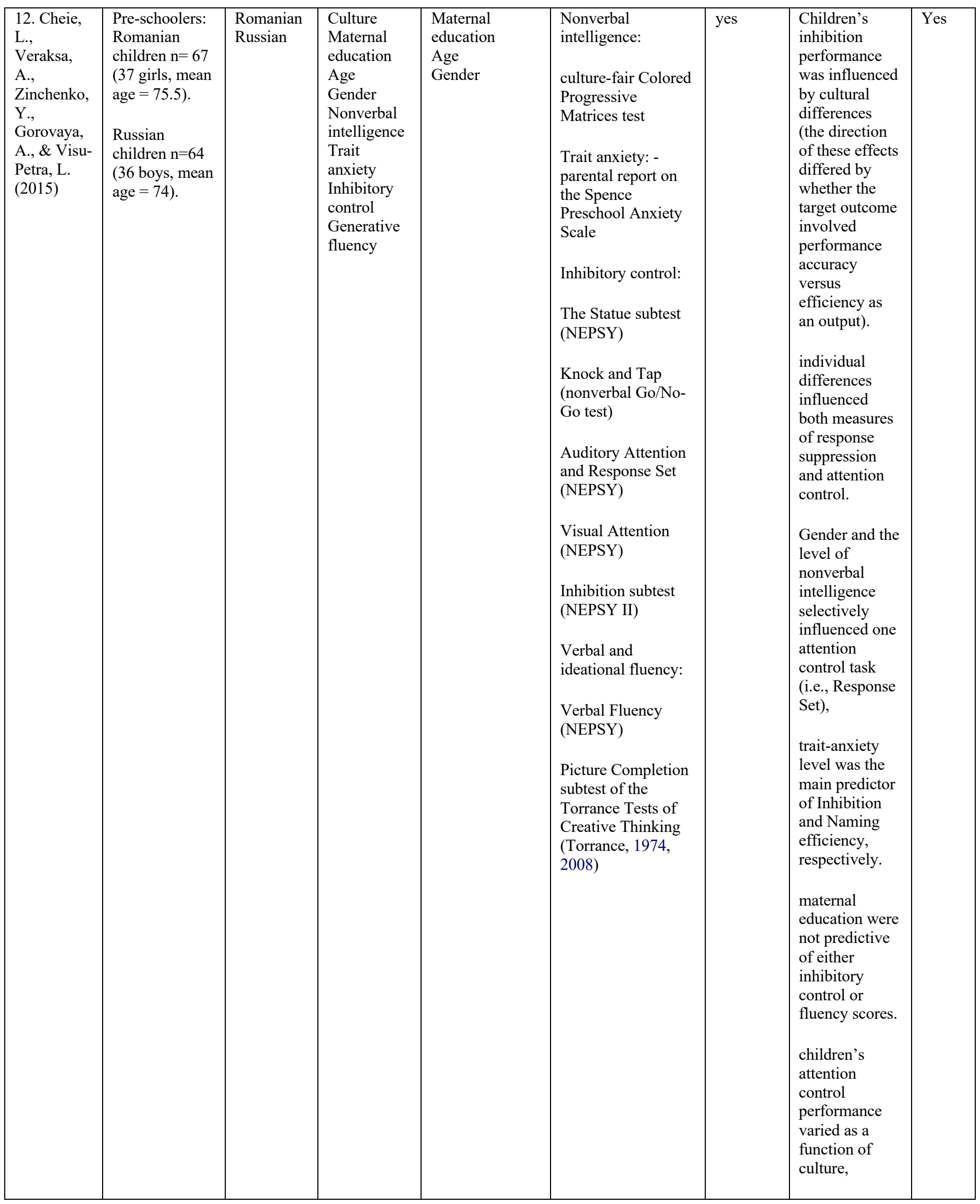




\begin{tabular}{|c|c|c|c|c|c|c|c|c|}
\hline & & & & & & & $\begin{array}{l}\text { Findings also } \\
\text { confirmed the } \\
\text { previously } \\
\text { documented } \\
\text { intensive } \\
\text { developmental } \\
\text { improvement } \\
\text { in } \\
\text { preschoolers' } \\
\text { inhibitory } \\
\text { control during } \\
\text { this period, } \\
\text { influencing } \\
\text { measures of } \\
\text { response } \\
\text { suppression } \\
\text { and } \\
\text { particularly } \\
\text { attention } \\
\text { control. } \\
\text { Finally, the } \\
\text { results further } \\
\text { stress the } \\
\text { importance of } \\
\text { individual } \\
\text { differences } \\
\text { effects in trait } \\
\text { anxiety on } \\
\text { attention } \\
\text { control } \\
\text { efficiency } \\
\text { across cultures. }\end{array}$ & \\
\hline $\begin{array}{l}\text { 13. Wang, } \\
\text { Z., Devine, } \\
\text { R. T., } \\
\text { Wong, K. } \\
\text { K., \& } \\
\text { Hughes, C. } \\
\text { (2015) }\end{array}$ & $\begin{array}{l}\text { sample 1: } \\
78 \text { children } \\
\text { from Hong } \\
\text { Kong and } 39 \\
\text { children from } \\
\text { UK. } \\
\text { Mean age : } \\
12.4 \text { years. } \\
-52 \% \text { girls. } \\
\text {-Recruited } \\
\text { from english } \\
\text { speaking } \\
\text { international } \\
\text { schools in } \\
\text { honk kong and } \\
\text { six state } \\
\text { primary and } \\
\text { secondary } \\
\text { school in the } \\
\text { UK. } \\
\\
\text { Sample 2: } \\
137 \text { children } \\
\text { from United } \\
\text { Kingdom } \\
\text { and125 } \\
\text { children from } \\
\text { Hong Kong } \\
\text { Mean age : } \\
10.8\end{array}$ & $\begin{array}{l}\text { British } \\
\text { Chinese } \\
\text { (Hong } \\
\text { Kong) }\end{array}$ & $\begin{array}{l}\text { Culture } \\
\text { Pedagogical } \\
\text { experience } \\
\text { (type of } \\
\text { school) } \\
\text { Theory of } \\
\text { mind } \\
\text { Inhibitory } \\
\text { control } \\
\text { working } \\
\text { memory } \\
\text { shifting/men } \\
\text { tal } \\
\text { flexibility }\end{array}$ & $\begin{array}{l}\text { Age controlled } \\
\text { Type of school } \\
\text { studied } \\
\text { Number of } \\
\text { siblings } \\
\text { controlled } \\
\text { Parental } \\
\text { education level } \\
\text { controlled } \\
\text { Affluence } \\
\text { controlled } \\
\text { Samples } \\
\text { matched for } \\
\text { gender }\end{array}$ & $\begin{array}{l}\text { Inhibition and set } \\
\text { shifting: } \\
\text { Bead Memory task } \\
\text { Switching and } \\
\text { visual attention : } \\
\text { Trail Making test } \\
\text { Inhibition : } \\
\text { Arrows Task } \\
\text { Flexibility : } \\
\text { Smiling Face task } \\
\text { Working memory : } \\
\text { Digit Span } \\
\text { Backward }\end{array}$ & no & $\begin{array}{l}\text { Hong Kongese } \\
>\text { British on } \\
\text { executive } \\
\text { function tasks. }\end{array}$ & Yes \\
\hline
\end{tabular}




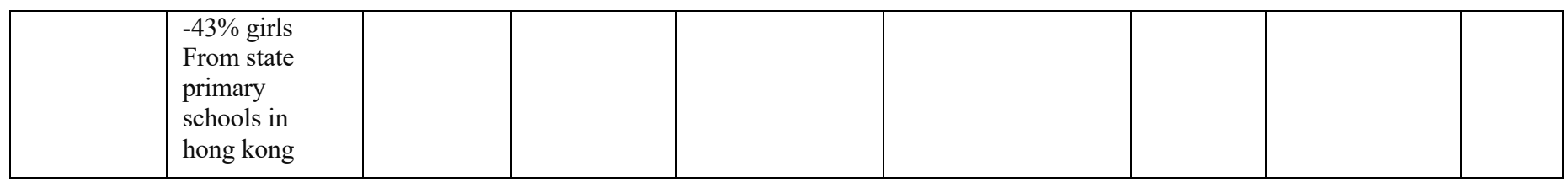

$>$ : better than; <: worse than; $=$ : same as

13 articles on cross-cultural differences of executive functions were found. 84\% (11/13) of the studies showed cross-cultural differences while 16\% (2/13) did not find cross-cultural differences across cultures.

\section{Demographic variables}

Thirteen out of 13 studies (100\%) either controlled or studied age, 11 out of 13 studies (84\%) either controlled or studied the variable 'gender', 1 out of 13 studies studied type of school while the other studies did not control this variable, 2 out of 13 controlled for parent's education level, 2 out of 13 controlled or studied 'language proficiency' (bilinguals versus monolinguals), 2 out of 13 controlled for number of siblings, and 1 out of 13 controlled for affluence.

Eight out of 13 studies (61\%) were conducted on preschoolers (2-7 years old), 4 out of 13 studies (30\%) were conducted on school-aged children (6-12 years old), and 1 study was conducted on groups ranging from pre-school to school-aged (4- 9 years old).

Two/13 studies included a sample size below 100,3/13 studies included samples ranging from 100 to 200 children, $3 / 13$ studies included samples ranging from 200 to 300 children, $2 / 13$ studies included samples of 300 to 400 children, and 2/13 studies included samples of more than 400 children.

\section{Geographic variables}

Twelve out of 13 studies (92\%) compared 2 cultures whereas 1 study compared more than 2 cultures. 5/13 (38\%) included Chinese groups, 4/13 (30\%) included American samples, 2/13 (15\%) included Korean samples, 2/13 (15\%) included British samples, 2/13 (15\%) included Japanese samples, 3/13 (23\%) included Canadian samples, 2/13 included Russian samples (15\%), 1/13 included an Indian sample, 1/13 included an Australian sample, 1/13 included an Italian sample, 1/13 included an Iranian sample, 1/13 included a German sample, 1/13 included a Costa Rican sample, 1/13 included a Cameroonian sample, 1/13 included a Kyrgyz sample, and 1/13 included a Romanian sample. Five/13 studies (38\%) compared an Asian Country to a North American country, 2/13 (15\%) studies compared an Asian country to a European country, 2/13 (15\%) studies compared two European cultures, 1 study compared two Asian countries, 1 study compared a European population to a North American population to an African population, and 1 study compared an Asian population to a European population to an Australian population, and 1 study compared subgroups of Canadian immigrants. 


\begin{tabular}{|c|c|c|c|c|}
\hline & $\begin{array}{l}\text { Studies that found } \\
\text { cross-cultural } \\
\text { differences }\end{array}$ & Main findings & $\begin{array}{l}\text { Studies that did } \\
\text { not find cross- } \\
\text { cultural } \\
\text { differences }\end{array}$ & $\begin{array}{c}\text { Main } \\
\text { findings }\end{array}$ \\
\hline Inhibition & $\begin{array}{c}\text { Lan et al., } 2011 \\
\text { Sabbagh et al., } 2006 \\
\text { Oh et al., } 2008 \\
\text { Chasiotis et al., } 2006 \\
\text { Rubin et al., } 2006 \\
\text { Thorell et al., } 2013 \\
\text { Cheie, L., et al. } 2014 \\
\text { Lahat et al. } 2010\end{array}$ & $\begin{array}{c}\text { Chinese }>\text { Americans } \\
\text { Chinese }>\text { Americans } \\
\text { Korean }>\text { British } \\
\text { Cameroonian }>\text { German } \\
\text { and Costa Rican in } \\
\text { delayed inhibition } \\
\text { German and Costa Rican } \\
>\text { Cameroonian in conflict } \\
\text { inhibition } \\
\text { Chinese and Korean }> \\
\text { Italian and Australian } \\
\text { Iranian }>\text { Chinese } \\
\text { Romanian and Russian } \\
\text { differed on tasks of } \\
\text { inhibition } \\
\text { - Chinese-canadian }= \\
\text { Europeam-canadian in } \\
\text { children's behavioral } \\
\text { performance on the task / } \\
\text { Chinese-Canadian } \\
\text { children showed more } \\
\text { activation in dorsomedial, } \\
\text { ventromedial, and } \\
\text { (bilateral) ventrolateral } \\
\text { prefrontal cortex. }\end{array}$ & $\begin{array}{l}\text { Bialystok et al., } \\
2009\end{array}$ & $\begin{array}{l}\text { Indian }= \\
\text { Canadian }\end{array}$ \\
\hline $\begin{array}{l}\text { Working } \\
\text { memory }\end{array}$ & $\begin{array}{l}\text { Thorell et al., } 2013 \\
\text { Oh et al., } 2008 \\
\text { Ismatullina et al., } \\
2014\end{array}$ & $\begin{array}{l}\text { Iranian }>\text { Chinese } \\
\text { Korean }>\text { British } \\
\text { Significant gender-by- } \\
\text { country interaction }\end{array}$ & & \\
\hline Flexibility & $\begin{array}{l}\text { Sabbagh et al., } 2006 \\
\text { Oh et al., } 2008 \\
\text { Imada et al., } 2013\end{array}$ & $\begin{array}{ll}\text { - } & \text { Chinese }>\text { Americans } \\
\text { - } & \text { Korean }>\text { British } \\
\text { - } & \text { Japanese }>\text { Americans }\end{array}$ & $\begin{array}{ll}- & \text { Bialystok et } \\
& \text { al., } 2009 \\
\text { - } & \text { Moriguchi et } \\
& \text { al., } 2012\end{array}$ & $\begin{array}{cc}- & \text { Canadian } \\
= & \text { Indian } \\
-\quad & \text { Canadian } \\
= \\
\text { Japanese }\end{array}$ \\
\hline Planning & -- & -- & -- & -- \\
\hline General & $\begin{array}{l}\text { Wang et al., } 2015 \\
\text { Thorell et al., } 2013\end{array}$ & $\begin{array}{c}\text { Chinese }>\text { British } \\
\text { Swedish, Spanish and } \\
\text { Iranian }>\text { Chinese }\end{array}$ & & \\
\hline
\end{tabular}




\section{Cognitive variables}

Eleven out of the 13 studies (84\%) used performance-based tests while the 2 others $(16 \%)$ used scales assessing symptoms related to executive dysfunctions in daily life (Thorell et al., 2013), and structured observation of toddlers (Rubin, 2006).

Four out of 13 studies $(30 \%)$ used tools that were translated and adapted to the children's culture. Nine out of 13 studies (69\%) assessed inhibition across included groups, 3 out of $13(23 \%)$ assessed working memory, and 5 out of $13(38 \%)$ assessed mental flexibility. None of the studies included measures on Planning. Nine out of $13(69 \%)$ studies included at least 2 executive functions whereas 4 out of $13(31 \%)$ included one executive function.

Regarding tests used, 21 different measures of inhibition were used across studies. The most widely used measure for inhibition was the Day/Night Stroop task that was used in 3 different studies. Working memory was assessed using 10 different tools and all of the measures used to assess working memory were used only once. Finally, mental flexibility or set-shifting was assessed using 4 different tools across studies, with the Dimensional-Change Card Sort being the most widely used as 4 different studies used this measure to assess mental flexibility.

\section{Table 3: Executive Function measures used accross studies}

\begin{tabular}{|c|c|c|}
\hline Function assessed & Measures used & $\begin{array}{l}\text { Number of times used } \\
\text { across studies }\end{array}$ \\
\hline \multirow[t]{21}{*}{ Inhibition } & Day/Night Stroop Task & 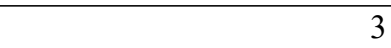 \\
\hline & Grass/Snow Stroop Task & 1 \\
\hline & Bear/Dragon Task (2) & 2 \\
\hline & Tower-Building Task (2) & 2 \\
\hline & Whisper Task & 1 \\
\hline & Hand game (2) & 2 \\
\hline & Self-control task & 1 \\
\hline & Snack delay & 1 \\
\hline & Gift delay (2) & 2 \\
\hline & Kansas Reflection-Impulsivity Scale for Preschoolers & 1 \\
\hline & Face task & 1 \\
\hline & Head-Toes-Knees-Shoulders (HTKS) task & 1 \\
\hline & Chexi & 1 \\
\hline & Arrows Task & 1 \\
\hline & Bead Memory task & 1 \\
\hline & Go No Go & 1 \\
\hline & The Statue subtest (NEPSY) & 1 \\
\hline & Knock and Tap (nonverbal Go/No-Go test) & 1 \\
\hline & Auditory Attention and Response Set (NEPSY) & 1 \\
\hline & Visual Attention (NEPSY) & 1 \\
\hline & Inhibition subtest (NEPSY II) & 1 \\
\hline
\end{tabular}

Roukoz Cynthia | Développement des Fonctions Exécutives chez les Enfants 44 
Backward word span task

Animal span task

Sequencing span task

Corsi blocks

The Sentence Completion task

Spatial Working Memory task from the CANTAB

battery

Chexi

Digit Span Backward

Flexibility/set shifting

Dimensional-Change Card Sort (4)

Table 4: Studies that found cross-cultural differences

\begin{tabular}{|c|c|c|c|c|c|c|}
\hline Study & $\begin{array}{l}\text { Cultures } \\
\text { compared }\end{array}$ & $\begin{array}{l}\text { Results } \\
\text { per } \\
\text { geogra } \\
\text { phic } \\
\text { contine } \\
\text { nts }\end{array}$ & $\begin{array}{l}\text { Type of } \\
\text { material }\end{array}$ & EF studied & $\begin{array}{l}\text { Sociodemographic } \\
\text { variable controlled } \\
\text { or studied }\end{array}$ & Sample \\
\hline $\begin{array}{l}\text { Chasiotis et } \\
\text { al. (2006) }\end{array}$ & $\begin{array}{l}\text { German Costa } \\
\text { Rican } \\
\text { Cameroonian }\end{array}$ & Variable & $\begin{array}{l}\text { Performance- } \\
\text { based }\end{array}$ & $\begin{array}{l}\text { Inhibition } \\
\text { Theory of } \\
\text { mind }\end{array}$ & $\begin{array}{l}\text { Age } \\
\text { Gender } \\
\text { Number of siblings } \\
\text { language understanding } \\
\text { mother's education }\end{array}$ & $\begin{array}{l}\mathrm{N}=314 \\
3-5 \text { years }\end{array}$ \\
\hline $\begin{array}{l}\text { Sabbagh et } \\
\text { al. (2006) }\end{array}$ & $\begin{array}{l}\text { Chinese } \\
\text { Americans }\end{array}$ & $\begin{array}{l}\text { East Asian > } \\
\text { North American }\end{array}$ & $\begin{array}{l}\text { Performance- } \\
\text { based and } \\
\text { scale }\end{array}$ & $\begin{array}{l}\text { Flexibility } \\
\text { Inhibition } \\
\text { Impulsivity }\end{array}$ & $\begin{array}{l}\text { Age } \\
\text { Gender }\end{array}$ & $\begin{array}{l}\mathrm{N}=216 \\
3.5- \\
4.5 \\
\text { years }\end{array}$ \\
\hline $\begin{array}{l}\text { Rubin et al. } \\
(2006)\end{array}$ & $\begin{array}{l}\text { Chinese } \\
\text { Korean } \\
\text { Italian } \\
\text { Australian }\end{array}$ & $\begin{array}{l}\text { East Asian }> \\
\text { European and } \\
\text { Australian }\end{array}$ & $\begin{array}{l}\text { Performance- } \\
\text { based }\end{array}$ & Inhibition & $\begin{array}{l}\text { Age } \\
\text { Gender }\end{array}$ & $\begin{array}{l}\mathrm{N}=586 \\
24- \\
26 \\
\text { months }\end{array}$ \\
\hline $\begin{array}{l}\text { Oh et al. } \\
(2008)\end{array}$ & $\begin{array}{l}\text { Korean } \\
\text { British }\end{array}$ & $\begin{array}{l}\text { East Asian > } \\
\text { European }\end{array}$ & $\begin{array}{l}\text { Laboratory } \\
\text { observation } \\
\text { of behavior }\end{array}$ & $\begin{array}{l}\text { Inhibition } \\
\text { Working } \\
\text { memory } \\
\text { Flexibility }\end{array}$ & Age & $\begin{array}{l}\mathrm{N}=180 \\
3.5-4 \text { years }\end{array}$ \\
\hline $\begin{array}{l}\text { Lan et al. } \\
(2011)\end{array}$ & $\begin{array}{l}\text { Chinese } \\
\text { Americans }\end{array}$ & $\begin{array}{l}\text { East Asian > } \\
\text { North American }\end{array}$ & $\begin{array}{l}\text { Performance- } \\
\text { based }\end{array}$ & $\begin{array}{l}\text { Inhibition } \\
\text { Attentional control } \\
\text { Working memory }\end{array}$ & $\begin{array}{l}\text { Age } \\
\text { Gender }\end{array}$ & $\begin{array}{l}\mathrm{N}=258 \\
3.1-6 \text { years }\end{array}$ \\
\hline
\end{tabular}




\begin{tabular}{|c|c|c|c|c|c|c|}
\hline $\begin{array}{l}\text { Thorell et al. } \\
\text { (2013) }\end{array}$ & $\begin{array}{l}\text { Iranian } \\
\text { Chinese } \\
\text { Swedish } \\
\text { Spanish }\end{array}$ & Variable & Scale & $\begin{array}{l}\text { Working memory } \\
\text { Inhibition }\end{array}$ & $\begin{array}{l}\text { Age } \\
\text { Gender }\end{array}$ & $\begin{array}{l}\mathrm{N}=481 \\
6-11 \text { years }\end{array}$ \\
\hline $\begin{array}{l}\text { Imada et al. } \\
(2013)\end{array}$ & $\begin{array}{l}\text { Japanese } \\
\text { Americans }\end{array}$ & $\begin{array}{l}\text { East Asian > } \\
\text { North American }\end{array}$ & $\begin{array}{l}\text { Performance- } \\
\text { based }\end{array}$ & Shifting & Age & $\begin{array}{l}N=175 \\
4-9 \text { years }\end{array}$ \\
\hline $\begin{array}{l}\text { Wang et al. } \\
(2015)\end{array}$ & $\begin{array}{l}\text { Chinese } \\
\text { British }\end{array}$ & $\begin{array}{l}\text { East Asian > } \\
\text { European }\end{array}$ & $\begin{array}{l}\text { Performance- } \\
\text { based }\end{array}$ & $\begin{array}{l}\text { Inhibitory control, } \\
\text { working memory } \\
\text { shifting }\end{array}$ & $\begin{array}{l}\text { Age } \\
\text { Type of school } \\
\text { Number of siblings } \\
\text { Parental education level } \\
\text { Affluence } \\
\text { Gender }\end{array}$ & $\begin{array}{l}\mathrm{N}=379 \\
9-16 \text { years }\end{array}$ \\
\hline $\begin{array}{l}\text { Cheie et al. } \\
\text { (2014) }\end{array}$ & $\begin{array}{l}\text { Romanian } \\
\text { Russian }\end{array}$ & $\begin{array}{l}\text { Children's } \\
\text { inhibition } \\
\text { performance } \\
\text { was influenced } \\
\text { by cultural } \\
\text { differences (the } \\
\text { direction of } \\
\text { these effects } \\
\text { differed by } \\
\text { whether the } \\
\text { target outcome } \\
\text { involved } \\
\text { performance } \\
\text { accuracy versus } \\
\text { efficiency as an } \\
\text { output). } \\
\text { Sionificant }\end{array}$ & $\begin{array}{l}\text { Performance- } \\
\text { based }\end{array}$ & $\begin{array}{l}\text { Inhibitory } \\
\text { control } \\
\text { Generative } \\
\text { fluency }\end{array}$ & $\begin{array}{l}\text { Maternal education } \\
\text { Age } \\
\text { Gender } \\
\text { Nonverbal intelligence } \\
\text { Trait anxiety }\end{array}$ & $\begin{array}{l}N=131 \\
5-7 \text { years }\end{array}$ \\
\hline $\begin{array}{l}\text { Ismatullina } \\
\text { et al. } \\
\text { (2014) }\end{array}$ & $\begin{array}{l}\text { Kyrgiz } \\
\text { Russian. }\end{array}$ & $\begin{array}{l}\text { Significant } \\
\text { gender- by- } \\
\text { country } \\
\text { interaction. } \\
\text { Chinese- } \\
\text { canadian = } \\
\text { Europeam- } \\
\text { canadian in } \\
\text { children's } \\
\text { behavioral }\end{array}$ & $\begin{array}{l}\text { Performance- } \\
\text { based }\end{array}$ & $\begin{array}{l}\text { Working } \\
\text { memory }\end{array}$ & $\begin{array}{l}\text { Age } \\
\text { Gender }\end{array}$ & $\begin{array}{l}\mathrm{N}=289 \\
10-17 \\
\text { years }\end{array}$ \\
\hline $\begin{array}{l}\text { Lahat et al. } \\
\text { (2010) }\end{array}$ & $\begin{array}{l}\text { Canadian } \\
\text { European- } \\
\text { Canadian }\end{array}$ & $\begin{array}{l}\text { performance on } \\
\text { the task- } \\
\text { Chinese- } \\
\text { Canadian } \\
\text { differed from } \\
\text { European- } \\
\text { canadian on } \\
\text { EEG recordings } \\
\text { during tasks }\end{array}$ & $\begin{array}{l}\text { Performance- } \\
\text { based EEG } \\
\text { recordings }\end{array}$ & Inhibition & $\begin{array}{l}\text { Age } \\
\text { Gender }\end{array}$ & $\begin{array}{l}\mathrm{N}=54 \\
5-7 \text { years }\end{array}$ \\
\hline
\end{tabular}




\section{Discussion}

This study reviewed published research in English and French on pediatric cross-cultural differences of inhibition, working memory, flexibility, and planning in reference to Diamond's theoretical model (Diamond, 2013). However, while Diamond accounts mainly for age when theorizing the developmental curve of EFs, she does not consider cultural and individual demographic variables as having a potential effect on EFs. Culture prescribes what should be learned at what age and by which gender therefore children emerging from different cultural backgrounds will have different patterns of abilities (Ardilla, 2005). Also, gender, language proficiency, type of school, parent's education level, and socio-economic level are known to have a potential effect on EFs development in children (Becker, Isaac, \& Hynd, 1987; Berlin \& Bohlin, 2002; Pena, Bedore, \& Zlatic-Giunta, 2002; Ardila et al., 2005; Aràn-Filippetti \& Richaud De Minzi, 2012; Hoff, 2003; Kohen et al., 2002). EFs develops in interaction with a child's environment and is potentially influenced by a child's social background. The present review examined studies targeting cross-cultural differences across cultures to understand if and how executive functions are culturally determined.

Our review suggests that $84 \%$ of studies conducted on executive functions in children and across cultures show EFs differences in one or more EFs in reference to Diamond's model (inhibition, flexibility, working memory, and planning). Chinese and Americans were the cultures most widely compared and results generally indicated better EFs performance among Chinese children. On a larger scale, children from East Asia (Japanese, Chinese, and Korean) were generally found to be more competent in terms of EFs than Western children (Europeans, Americans, Australian), (Sabbagh et al., 2006; Rubin et al., 2006; Oh \& Lewis, 2008; Lan et al., 2011; Imada, Carlson, \& Itakura, 2013; Wang et al., 2016). African children were only represented in one study (Chasiotis et al., 2006) and results were variable since Cameroonian children performed less well than German and Costa Rican on a task using conflict inhibition but significantly better on a task using delayed inhibition. Australian children were also represented in only one study and were considered less efficient than Asian children on tasks of EFs (Rubin et al., 2006).

Taken together, results show better EF performance in East Asian children when compared to European, American, and Australian children. Differences were inconsistently observed on tasks of inhibition, working memory, and mental flexibility. Inhibition was the most assessed function and was broadly considered more developed in Asian children. For example, according to Sabbagh et al. (2006), Chinese children outperformed their American counterparts in measures of inhibition and mental flexibility. Wang et al. (2016) showed better performance on tasks of inhibitory control, working memory, and shifting in Chinese children from private and public schools when compared to British counterparts. Taking into account Diamond's model of EFs, inhibitory control underlies the development of all executive components supporting the fact that better inhibitory control at an early age will lead to better executive functions later. Therefore, we can presume that East Asian children will develop better executive skills than children emerging from other countries, since they are starting off with better inhibitory control. While East Asian children were generally considered more advanced than their American, European, 
and Australian counterparts on EFs related processes, several hypotheses were suggested to understand those differences. Differences in EFs across cultures were attributed to both sociocultural and genetic factors (Lan et al., 2011; Sabbagh et al., 2006; Rubin et al., 2006). One of the socio-cultural explanations was that Chinese parents and teachers value impulse control since early childhood. Cultural psychologists have noted that Chinese parents expect 2-year- old children to master impulse control, whereas this skill is not as valued and encouraged in U.S. toddlers (Sabbagh et al., 2006). Therefore, it was emphasized that Chinese children may have more opportunities to practice inhibition and impulse control, resulting in better EFs at a later stage. A second explanation emerges from the field of genetic studies: Chang et al. (1996) suggested that since the 7-repeat allele, associated with ADHD - therefore executive dysfunction - is very rare in East and South Asia (including China), especially when compared to US, and it can possibly contribute to better EFs in Chinese or more generally East Asians (Chang et al., 1996). For these reasons, Chinese children may have an advantage in executive functioning (Sabbagh et al., 2006). Also, according to Calkins, Fox, and Marshall (1996) physiological correlates can be accounted for better inhibition in children aged 9, 14, and 24 months. By recording brain electrical activity of toddlers, they found that infants who displayed a pattern of asymmetry right frontal EEG displayed more behavioral inhibition than other toddlers. Presumably, these physiological correlates are a product of genetic and environmental influences.

Even though these individual studies suggest that EFs will be influenced by culture, they share one same limitation being the sociodemographic variables controlled. Recent studies suggest that the developmental curve of EFs is subject to be influenced by sociodemographic variables. According to previous studies, sociodemographic variables such as gender, language proficiency, type of education, and parent's education level have a potential effect on the developmental curve of EFs (Ardila et al., 2005; Halpern, 2000; Carlson \& Meltzoff, 2008; Ratcliff et al., 1998), aside from a child's age. While all studies took into account the potential effect of gender and age on EFs, not all studies observed the potential effect of other sociodemographic variables such as parent's education level, type of school, and language proficiency. Bialystok and Viswanathan (2009) studied the interaction between language proficiency and culture and though they did not observe crosscultural differences on EFs performance, they showed a significant effect of bilingualism on EFs performance. Canadian and Indian bilinguals performed better than Canadian and Indian monolingual on tasks of inhibitory control and cognitive flexibility whereas Canadian and Indian bilinguals had similar performance on tasks of EFs. Also, significant gender-by-country interactions were observed in 2 studies (Thorell, et al., 2013; Imada, Carlson, \& Itakura, 2013). Imada, Carlson, and Itakura (2013) observed better EFs in Kyrgyz males when compared to Kyrgiz females on a spatial working memory task whereas the opposite was observed on Russians. Similar gender by country differences were observed by Thorell et al. (2013) who reported less EFs symptoms in daily life in Iranian boys when compared to girls, while the opposite - worse EFs in boys when compared to girls - was observed in Swedish children. Also, while comparing Russian to Romanian preschoolers, Cheie et al. (2015) observed that individual differences including gender, maternal level of education, level of nonverbal intelligence, and trait-anxiety influenced measures of inhibition and attention control. Therefore, sociodemographic variable can have a direct influence on EFs development within and across cultures and influences of 
these variables can be different depending on the culture studied. Consequently, in order to compare different cultures on EFs skills, authors should control different individual sociodemographic variables that might have influenced EFs development.

From a clinical point of view, despite the growing body of literature on the significant effect of cultural and sociodemographic factors that can potentially influence the development of EFs, the theoretical models available to date do not take into consideration the predictive effect of the environment and culture on EFs when drawing a developmental curve of EFs across childhood. Therefore, generalizing these EFs models across different contexts remains problematic. Studies should therefore be conducted in different countries to better understand how EFs develops in a given country. Ardila (2005) emphasizes that understanding the variables that can influence test performance and gathering normative data on culturally different groups is of primary importance to understand and assess cognitive functions in different cultural contexts. Given the heterogeneous development of core EF across culture, Bellaj and Le Gall (2016) highlight the importance of considering several aspects when studying the neuropsychological functioning of a given population. First, sociocognitive aspects such as what is considered as deviant or normal behavior in a given population should be acknowledged. For instance, the behavior usually tolerated in an American preschooler is not in a Chinese preschooler since impulse control is more valued and encouraged in Chinese preschool than in U.S. (Tobin, Wu, \& Davidson, 1989). Also, according to Byrne et al. (2009) should be considered whether the tools used to evaluate a given function require the same cognitive demands across cultures thus if the psychological constructs are the same across cultural groups. Also, should be considered if the content and psychometric properties of a test (i.e., validity and reliability) are similar across groups.

Unfortunately, very few studies are being conducted on populations from the Middle East and North Africa (MENA) region. Among the studies included in our review, no study used samples from Middle Eastern or North African countries. To date, no data on how EFs develop in these countries are available nor do we have tools to assess these children, even though these countries provide, among public and private institutions, neuropsychological services for children. The early vulnerability of EFs in early childhood and the multiple conditions that lead to executive dysfunctions makes it a priority in child neuropsychology. For example, impairments of planning, inhibition, mental flexibility, working memory, and attention control were described in several acquired and developmental disorders affecting the frontal lobes and frontal subcortical circuitry. Disorders such as traumatic brain injuries, epilepsy, brain tumors, vascular diseases, Attention Deficit/Hyperactivity Disorder, premature birth, learning disorders, Autism Spectrum Disorders, Neurofibromatosis type 1, or Phenylketonuria are typically considered to hinder executive functions progress in a developing brain (Roy et al., 2012). However, lack of tools adapted to the population, lack of understanding related to the developmental curve of EFs across these understudied cultural groups, and lack of understanding related to sociodemographic variables that might influence EFs development, are all an obstacle to the study of EFs in different cultures. Adaptation of tools in Arabic appears to be of primary importance to better understand how EFs develops across Arab cultures, if EFs as a construct is different across these cultures, and how EFs is influenced by sociodemographic variables. Developing tools adapted to Arab populations and understanding the developmental trend of EFs in those countries will help us better understand clinical populations 
and improve treatments accordingly.

Although the present study is the first study to give an overview of data published on cross-cultural studies on EFs in children, there are many limitations to it as we used independent studies using independent tools that are not comparable due to diverse methodological biases. According to Van De Vijver (2010), if scores are biased, their meaning varies across groups and constructs and scores are therefore not directly comparable across cultures. For example, tools used by the different researchers differ across studies with some using diverse performance-based tests and others using scales or clinical observation of toddlers. Diversity of tools used might explain many of the inconsistencies observed across studies comparing the same cultures. For example, Thorell et al. (2013) observed, among Chinese children, more EFs difficulties in daily life when compared to Iranians, Swedish, and Spanish children using parents and teachers rating scales (CHEXI). Their findings contradicts results of other studies showing better EFs in Chinese children when compared to North American, European, and Australian children (Sabbagh et al., 2006; Rubin et al., 2006; Oh \& Lewis, 2008; Lan et al., 2011; Imada, Carlson, \& Itakura, 2013; Wang et al., 2016). In other words, Thorell's results were probably affected by the tendency of Chinese parents and teachers to be more severe when assessing impulse control since it is a skill that is valued and highly encouraged in Chinese toddlers. Conversely, using a different scale assessing daily life symptoms related to impulse control (Kansas Reflection- Impulsivity Scale for Preschoolers), Sabbagh et al. (2006) showed less EFs deficits in Chinese children when compared to Americans. Therefore, scales and tests used among studies were different and led to contradictory results among studies. Van de Vijvre (2010) previously described these types of biases as response style bias. It is also important to consider whether the tasks used engaged the same executive demands across cultures (Sabbagh et al., 2006), especially that tools were, for the most, not adapted to the cultures studied which will lead to what van de Vijver refers to as construct bias. Psychological constructs that are not equivalent across countries lack a shared meaning, which precludes any cross-cultural comparison (Van de Vijvre, 2010).

To conclude, executive function development in children appears to be heterogeneous across cultures and across subgroups within a given culture. However, we cannot draw conclusions about the cultural invariance of EFs, because the studies reviewed used different methods and measures of EFs therefore precluding proper cross-cultural comparisons. Consequently, to facilitate crosscultural comparisons in EFs, it is important not only to adapt tools in a new language, but also to establish the equivalence of the new tools with known neuropsychological measures. More generally, it will lead to a better overview of EFs development across children coming from different cultures as it will allow to compare norms from different countries and have a better sense of the executive functions that are influenced by cultures, as well as the ones that might be invariant from one culture to another. This next step seems to be essential in understanding the ontogenetic development of EFs and consequently explain the differential and normative developmental trends. 


\section{References}

Arán-Filippetti, V., \& Richaud de Minzi, M. C. (2012). A Structural Analysis of Executive Functions and

Socioeconomic Status in School-Age Children: Cognitive Factors as Effect Mediators. The Journal of Genetic Psychology, 173(4), 393-416.

https://doi.org/10.1080/00221325.2011. 602374

Ardila1, A. (2005). Cultural Values Underlying Psychometric Cognitive Testing. Neuropsychology Review, 15(4), 185.

https://doi.org/10.1007/s11065-0059180-y

Ardila, A., Rosselli, M., Matute, E., \& Guajardo, S. (2005). The Influence of the Parents' Educational Level on the Development of Executive Functions. Developmental Neuropsychology, 28(1), 539-560.

https://doi.org/10.1207/s15326942dn28 01_5

Becker, M. G., Isaac, W., \& Hynd, G. W (1987). Neuropsychological development of nonverbal behaviors attributed to "frontal lobe" functioning. Developmental Neuropsychology, 3(34), 275-298.

https://doi.org/10.1080/8756564870954 0381
Bellaj, T., \& Le Gall, D. (2016). L'évaluation neuropsychologique dans le contexte du Maghreb. In Amieva H., Belin C., \& Maillet D., (Eds.), L'évaluation neuropsychologique: De la norme à l'exception (pp. 165-90). Bruxelles: De Boeck supérieur.

Bellaj, T., Salhi, I., Le Gall, D., \& Roy, A. (2016). Development of executive functioning in school-age Tunisian children. Child Neuropsychology, 22(8), 919-954.

https://doi.org/10.1080/09297049.2015. 1058349

Bellaj T., \& Seron X. (2014). Les facteurs culturels dans l'évaluation neuropsychologique. In Seron X, van der Linden, M. (Eds.), Traité de Neuropsychologie Clinique de l'Adulte, 2ème édition (pp. 641-658). Marseille : De Boeck-Solal.

Berlin, L., \& Bohlin, G. (2002). Response Inhibition, Hyperactivity, and Conduct Problems Among Preschool Children. Journal of Clinical Child \& Adolescent Psychology, 31(2), 242-251. https://doi.org/10.1207/S15374424JCC P3102_09

Bernier, A., Carlson, S. M., \& Whipple, N. (2010). From External Regulation to Self-Regulation: Early Parenting Precursors of Young Children's Executive Functioning. Child Development, 81(1), 326-339. https://doi.org/10.1111/j.14678624.2009.01397.x

Bialystok, E., \& Viswanathan, M. (2009). Components of executive control with advantages for bilingual children in two cultures. Cognition, 112(3), 494-500. 
https://doi.org/https://doi.org/10.1016/j. cognition.2009.06.014

Brocki, K. C., \& Bohlin, G. (2004).

Executive Functions in Children Aged 6 to 13: A Dimensional and Developmental Study. Developmental Neuropsychology, 26(2), 571-593. https://doi.org/10.1207/s15326942dn26 023

Byrne, B. M., Oakland, T., Leong, F. T. L., van de Vijver, F. J. R., Hambleton, R. K., Cheung, F. M., \& Bartram, D. (2009). A critical analysis of crosscultural research and testing practices: Implications for improved education and training in psychology. Training and Education in Professional Psychology, 3(2), 94. Retrieved from http://citeseerx.ist.psu.edu/viewdoc/do wnload?doi=10.1.1.986.9463\&rep=rep $1 \&$ type $=$ pdf

Cheie, L., Veraksa, A., Zinchenko, Y., Gorovaya, A., \& Visu-Petra, L. (2015). A cross-cultural investigation of inhibitory control, generative fluency, and anxiety symptoms in Romanian and Russian preschoolers. Child Neuropsychology, 21(2), 121-149. https://doi.org/10.1080/09297049.2013. 879111

Calkins, S. D., Fox, N. A., \& Marshall, T. R. (1996). Behavioral and Physiological Antecedents of Inhibited and Uninhibited Behavior. Child Development, 67(2), 523-540. https://doi.org/10.1111/j.14678624.1996.tb01749.x

Carlson, S. M., \& Meltzoff, A. N. (2008). Bilingual experience and executive functioning in young children. Developmental Science, 11(2), 282-
298. https://doi.org/10.1111/j.14677687.2008.00675.x

Chang, F.-M., Kidd, J. R., Livak, K. J., Pakstis, A. J., \& Kidd, K. K. (1996) The world-wide distribution of allele frequencies at the human dopamine D4 receptor locus. Human Genetics, 98(1), 91-101.

https://doi.org/10.1007/s004390050166

Chasiotis, A., Kiessling, F., Hofer, J., \& Campos, D. (2006). Theory of mind and inhibitory control in three cultures: Conflict inhibition predicts false belief understanding in Germany, Costa Rica and Cameroon. International Journal of Behavioral Development, 30(3), 249-260. https://doi.org/10.1177/0165025406066 759

Dennis, M. (2006). Prefrontal cortex:

Typical and atypical development. In J. Risberg \& J. Grafman (Eds.), The frontal lobes: Development, function and pathology (pp.128-162). New York: Cambridge University Press.

Diamond, A. (2013). Executive Functions. Annual Review of Psychology, 64(1), 135-168. https://doi.org/10.1146/annurev-psych113011-143750

Fernández, A. L., \& Marcopulos, B. A. (2008). A comparison of normative data for the Trail Making Test from several countries: Equivalence of norms and considerations for interpretation. Scandinavian Journal of Psychology, 49(3), 239-246. https://doi.org/10.1111/j.14679450.2008.00637.x 
Halpern, D.F. (2000). Sex differences in cognitive abilities ( $3 r d$ ed.). Mahwah : Lawrence Erlbaum Associates.

Hoff, E. (2003). The Specificity of Environmental Influence: Socioeconomic Status Affects Early Vocabulary Development Via Maternal Speech. Child Development, 74(5), 1368-1378.

https://doi.org/10.1111/14678624.00612

Imada, T., Carlson, S. M., \& Itakura, S. (2013). East-West cultural differences in context-sensitivity are evident in early childhood. Developmental Science, 16(2), 198-208. https://doi.org/10.1111/desc.12016

Ismatullina, V., Voronin, I., Shelemetieva, A., \& Malykh, S. (2014). Cross-cultural Study of Working Memory in Adolescents. Procedia - Social and Behavioral Sciences, 146, 353-357. https://doi.org/https://doi.org/10.1016/j. sbspro.2014.08.111

Kohen, D. E., Brooks-Gunn, J., Leventhal, T., \& Hertzman, C. (2002). Neighborhood Income and Physical and Social Disorder in Canada: Associations with Young Children's Competencies. Child Development, 73(6), 1844-1860. https://doi.org/10.1111/1467-8624.t01$1-00510$

Lan, X., Legare, C. H., Ponitz, C. C., Li, S., \& Morrison, F. J. (2011). Investigating the links between the subcomponents of executive function and academic achievement: A cross-cultural analysis of Chinese and American preschoolers. Journal of Experimental Child Psychology, 108(3), 677-692. https://doi.org/https://doi.org/10.1016/j. jecp.2010.11.001

Lahat, A., Todd, R., Mahy, C., Lau, K., \& Zelazo, P. (2010). Neurophysiological correlates of executive function: a comparison of european-canadian and chinese-canadian 5-year-olds .

Frontiers in Human Neuroscience.

Retrieved from

https://www.frontiersin.org/article/10.3 389/neuro.09.072.2009

Luria, A. R. (1966). Higher cortical functions in man. New York: Basic Books.

Miyake, A., Friedman, N. P., Emerson, M. J., Witzki, A. H., Howerter, A., \& Wager, T. D. (2000). The Unity and Diversity of Executive Functions and Their Contributions to Complex "Frontal Lobe" Tasks: A Latent Variable Analysis. Cognitive Psychology, 41(1), 49-100. https://doi.org/https://doi.org/10.1006/c ogp.1999.0734

Moriguchi, Y., Evans, A. D., Hiraki, K., Itakura, S., \& Lee, K. (2012). Cultural differences in the development of cognitive shifting: East-West comparison. Journal of Experimental Child Psychology, 111(2), 156-163. https://doi.org/https://doi.org/10.1016/j. jecp.2011.09.001

Nell, V. (2000). Cross-cultural neuropsychological assessment: Theory and practice. Mahwah, NJ: Lawrence Erlbaum Associates, Inc.

Oh, S., \& Lewis, C. (2008). Korean Preschoolers' Advanced Inhibitory Control and Its Relation to Other Executive Skills and Mental State 
Understanding. Child Development, 79(1), 80-99.

https://doi.org/10.1111/j.1467-

8624.2007.01112.x

Pena, E. D., Bedore, L. M., \& Zlatic-Giunta, R. (2002). Category-Generation Performance of Bilingual Children. Journal of Speech, Language, and Hearing Research, 45(5), 938-947. https://doi.org/10.1044/10924388(2002/076)

Rabbit, P. (1997). Methodology of frontal and executive function. Psychological Press, Hove.

Ratcliff, G., Ganguli, M., Chandra, V., Sharma, S., Belle, S., Seaberg, E., \& Pandav, R. (1998). Effects of Literacy and Education on Measures of Word Fluency. Brain and Language, 61(1), 115-122.

https://doi.org/https://doi.org/10.1006/b rln.1997.1858

Rhoades, B. L., Greenberg, M. T., Lanza, S. T., \& Blair, C. (2011). Demographic and familial predictors of early executive function development: Contribution of a person-centered perspective. Journal of Experimental Child Psychology, 108(3), 638-662. https://doi.org/https://doi.org/10.1016/j. jecp.2010.08.004

Roy, A., Le Gall, D., Roulin, J. \& Fournet, N. (2012). Les fonctions exécutives chez l'enfant : approche épistémologique et sémiologie clinique. Revue de neuropsychologie, volume 4(4), 287-297. doi:10.3917/rne.044.0287.

Rubin, K. H., Hemphill, S. A., Chen, X., Hastings, P., Sanson, A., Coco, A. Lo,
... Cui, L. (2006). A cross-cultural study of behavioral inhibition in toddlers: East-West-North-South. International Journal of Behavioral Development, 30(3), 219-226. https://doi.org/10.1177/0165025406066 723

Sabbagh, M. A., Xu, F., Carlson, S. M., Moses, L. J., \& Lee, K. (2006). The Development of Executive Functioning and Theory of Mind: A Comparison of Chinese and U.S. Preschoolers.

Psychological Science, 17(1), 74-81. https://doi.org/10.1111/j.14679280.2005.01667.x

Seron, X., van der Linden, M., \& Andrès, P. (1999). Le lobe frontal: à la recherche de ses spécificités fonctionnelles. In van der Linden, M., Seron, X., Le Gall, D., Andrès, P., (Eds.), Neuropsychologie des lobes frontaux (pp. 33-88).Marseille : Solal.

Thorell, L. B., Veleiro, A., Siu, A. F. Y., \& Mohammadi, H. (2013). Examining the relation between ratings of executive functioning and academic achievement: Findings from a cross-cultural study. Child Neuropsychology, 19(6), 630638. https://doi.org/10.1080/09297049.2012. 727792

Tobin, J., Wu, D., \& Davidson, D. (1989). Preschool in Three Cultures: Japan, China and the United States. New Haven, CT: Yale University Press.

Van de Vijver, F. J. R. (2011). Bias and real differences in cross-cultural differences. In F. J. R. van de Vijver, A. Chasiotis, \& S. M. Breugelmans (Eds). Fundamental questions in crosscultural psychology, (pp. 235-257). 
Ainsi, les résultats disponibles à ce jour semblent suggérer que les FE ne se développent pas de manière homogène chez les enfants issus de différentes cultures. Ces données empiriques viennent ainsi questionner l'universalité des modèles de développement de FE, tel que celui de Diamond (2013), qui dresse un calendrier développemental des principales FE. De ce fait, l'étude des FE dans différents contextes culturels est d'une importance capitale, tant sur le plan théorique que clinique. Malgré le besoin, peu d'études se sont intéressées à la question des FE dans le monde arabe. Bellaj et al. (2015) mentionnent quatre études auprès de populations arabophones, mais ces dernières présentent de nombreuses limites. Bellaj et al. (2015) ont publié un article dressant un calendrier développemental des FE chez les enfants tunisiens mais cette étude n'est pas forcément généralisable au contexte libanais compte tenu des vastes différences culturelles entre le Liban et la Tunisie. Par exemple, les différences socioéconomiques (https://fr.countryeconomy.com/pays/comparer/liban/tunisie), les différences au niveau des constitutions politiques, religieuses, et éducatives (Arieff \& Humud, 2014; Krafft \& Alawode, 2018), et enfin, les différences au niveau du mode de vie entre les deux pays rend difficile la généralisation des résultats.

L'un des principaux obstacles à l'établissement de telles études reste le manque d'outils d'évaluation adaptés aux différents contextes culturels.

\subsection{L'évaluation des FE chez l'enfant}

Il existe, désormais, de nombreux tests d'évaluation des FE chez l'enfant. Certaines batteries (i.e. NEPSY II, DKEFS, TEA-Ch) proposent des tests d'évaluation classiques permettant d'évaluer un ensemble de composantes exécutives et d'en présumer, ou inférer le cas échéant, les difficultés de l'enfant au quotidien. Cependant, ces épreuves pourraient manquer de sensibilité dans la mesure où elles ne reflèteraient pas suffisamment l'engagement des FE dans les situations de vie quotidienne (Roy et al., 2012 ; Roy et al., 2017). D’ailleurs, Bronfenbrenner (1977) illustre les limites de l'évaluation cognitive conventionelle chez l'enfant. Dù au caractère étrange et nouveau d'une évaluation dans un contexte similaire à une situation de « laboratoire », l'anxieté d'un enfant pourrait s'amplifier, impactant ainsi ses performances. De ce fait, différents types d'outils ont été proposés afin d'apprécier l'efficience des FE dans l'environnement naturel de l'enfant. Parmi ces outils, les questionnaires comportementaux tels que la BRIEF visent à appréhender les FE dans différents 
contextes de la vie quotidienne de l'enfant du point de vue de ses parents ou de l'enseignant (Gioia et al., 2000 ; Roy et al., 2013). La BRIEF propose plusieurs questions rapportant à différentes facettes des FE (par exemple, contrôle émotionnel, inhibition, MDT, planification/organisation etc.) permettant d'apprécier l'efficience de chaque domaine individuellement et dans differents contextes.

Cependant, l'une des limites principales à l'évaluation des FE chez l'enfant reste le manque d'étalonnages normatifs appropriés dans différents contextes culturels. L'absence d'outils d'évaluation adaptés à la langue et à la culture locale demeure le principal obstacle dans l'étude des FE au Liban ainsi que dans d'autres pays Arabes. Afin de compenser ce manque d'outils, il est coutume d'utiliser des outils étrangers, Français, Américain ou Anglais, afin d'évaluer le fonctionnement exécutif des enfants Libanais. Néanmoins, au vu des vastes différences interculturelles au niveau du développement des FE (Roukoz et. al., 2018), cette approche présente le risque de déboucher sur de probables résultats biaisés. En effet, Fernandez et Marcopulos (2008) ont conduit une étude dans dix pays différents auprès d'individus âgés de 15 à 83 ans et ont montré que les différences en matière de données normatives sont si grandes qu'un individu peut se retrouver déficitaire si ses performances sont analysées avec les données du pays voisin (Fernandez \& Marcopulos, 2008).

Toutefois, la traduction littérale d'un test ne suffit pas à assurer que l'outil ainsi traduit évalue le même construit psychologique que sa version originale (Byrne \& Van Devijver, 2010). Le travail d'adaptation d'un outil psychométrique inclut donc plusieurs étapes de traduction d'une langue d'origine à une langue cible, puis une adaptation spécifique de certains items à la culture cible et enfin, une vérification de la validité de cet outil dans la culture visée. Ce travail d'adaptation d'outils est le seul moyen de contrôler les biais culturels dans l'étude du développement normal et pathologique des FE chez les enfants libanais.

Dans cette perspective, le projet FEE (Fonctions Exécutives de l'Enfants), proposé par un groupe de recherche multicentrique coordonné par les laboratoires de recherche des universités d'Angers et de Savoie Chambery (Roy, Fournet, Le Gall, \& Roulin), a été initié en 2009. Le protocole FEE a été conçu dans l'objectif de mettre à disposition des cliniciens Français des outils d'évaluation des FE et de favoriser la reconnaissance du syndrome dysexécutif auprès de la population pédiatrique. Ce projet s'est graduellement inscrit dans une perspective internationale débouchant sur une validation de l'outil dans différents pays, parmi lesquels la Tunisie, le Brésil, le Liban et le Maroc, 
en suivant une méthodologie commune. L'un des objectifs du projet FEE était donc de favoriser l'évaluation des FE dans différents pays qui ne disposent pas, pour l'instant, d'outils d'évaluation fiables. Dans un deuxième temps, l'enjeu constituait à étudier le développement typique et perturbé des FE dans différents contextes culturels.

Le protocole FEE est constitué de 12 tests évaluant 4 dimensions des FE (inhibition, mémoire de travail, planification et flexibilité) et de 3 questionnaires évaluant les comportements associés aux dysfonctionnement exécutifs chez l'enfant. La figure 3 présente les différents tests du protocole FEE dans sa version originale. Afin de tenir compte des fonctions cognitives non-exécutives dans les performances d'un enfant, les subtests « Matrices » et « Vocabulaire » de la WISC-IV ont également été retenus dans le protocole.

Figure 3 : Tests du protocole FEE

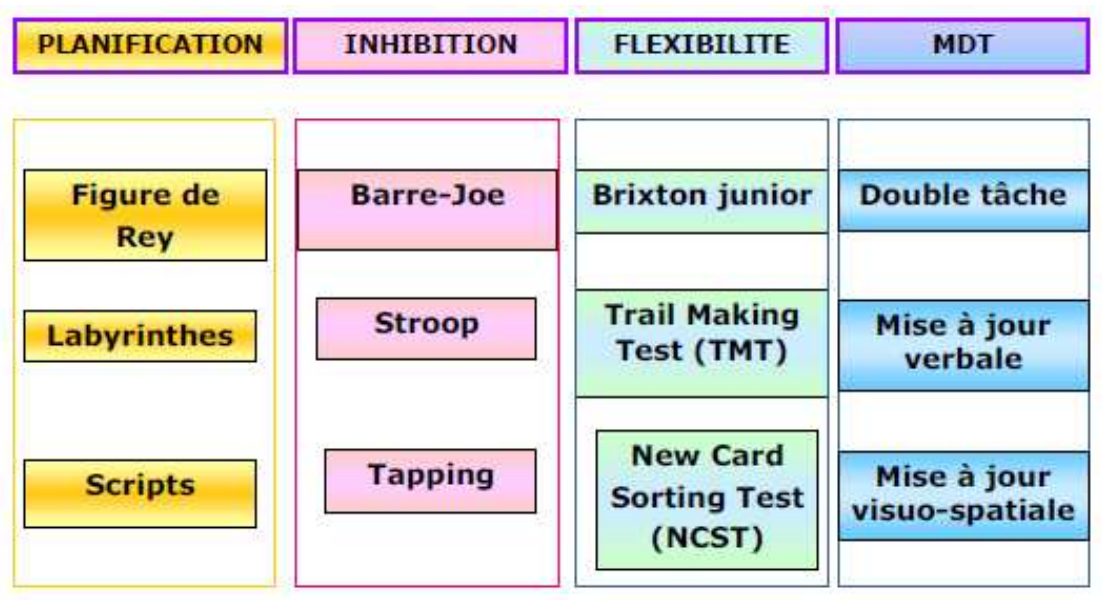

BRIEF 


\subsection{Clinique des troubles de FE chez l'enfant}

Le statut développemental particulièrement précoce mais prolongé des FE contribue à un risque de vulnérabilité précoce. En effet, des perturbations précoces des FE sont avérées ou suspectées dans diverses pathologies neurodéveloppementales et acquises tels que le TDA/H, le trouble du spectre autistique, la neurofibromatose de type 1, la drépanocytose, les troubles spécifiques du langage, les épilepsies, le traumatisme crânien, ou les tumeurs cérébrales (Roy et al., 2012). Cette fragilité est en lien avec la vulnérabilité précoce des réseaux fronto-sous-corticaux chez l'enfant, du fait du développement prolongé de ces réseaux tout au long de l'enfance (Tranel \& Eslinger, 2000).

L'ensemble des travaux s'étant intéressés au syndrome dysexécutif chez l'enfant indique une symptomatologie variable de troubles exécutifs cognitifs et comportementaux (Roy et al., 2012). Les symptômes comportementaux se présentent sous la forme d'une dichotomie semblable à celle retrouvée chez l'adulte, à savoir un versant pseudo-psychopathique et un versant pseudo-dépressif. Le versant pseudopsychopathique semble le plus fréquent chez l'enfant et se manifeste, de manière générale, par des comportements d'irritabilité et d'agressivité, une intolérance à la frustration, une impulsivité, une labilité émotionnelle ainsi que des accès incontrôlables de violence (Roy et al., 2012). Les troubles sont souvent durables jusqu'à l'âge adulte (Grattan \& Eslinger, 1992). En effet, Grattan et Eslinger (1992) décrivent le profil cognitif et comportemental d'une adulte de 33 ans, 26 ans après avoir subi des lésions frontales. Les comportements décrits se caracterisent par des déficits au niveau de la régulation comportementale et émotionelle ainsi que des comportements sociaux inappropriés et des troubles cognitifs « de haut niveau ». Les auteurs décrivent une apparition « retardée » de ces difficultés, compte tenu du développement prolongé des FE, ainsi qu'un arrêt de développement à l'adolescence. Plusieurs autres études ont également décrit des troubles de planification et de prise de décision, des difficultés de contrôle émotionel et comportemental et des comportements sociaux inappropriés chez des adultes ayant subi des lésions frontales durant l'enfance (Anderson et al., 2000; Grattan \& Eslinger, 1992; Price et al., 1990). 
D’un autre côté, les troubles cognitifs généralement décrits sont des difficultés de planification, de flexibilité mentale, d'inhibition, de MDT, de résolution de problème et d'attention qui affectent, à leur tour, l'ensemble des fonctions cognitives (Roy et al., 2012 ; Anderson et al., 2000). Une atteinte préférentielle de certaines FE cognitives malgré la préservation d'autres semble également possible (Roy et al., 2012). En ce sens, le syndrome dysexécutif apparaît donc variable et des troubles d'inhibition, de flexibilité mentale, de MDT et de planification peuvent apparaître de manière sélective ou plurielle chez un même enfant, ce qui témoigne d'ailleurs de la nature multifactorielle des FE.

Des dissociations peuvent également survenir entre les FE comportemetales et cognitives. En effet, un trouble majeur des FE cognitives chez l'enfant peut se présenter de manière isolée, en l'absence de perturbations du registre comportemental, et inversement, des troubles du registre comportemental peuvent exister sans dysfonctionnements cognitifs (Roy et al., 2012). Selon Chan et al. (2008), chacun de ces dysfonctionnements exécutifs serait associé à une partie du cortex préfrontal : les $\mathrm{FE}$ «cold» ou FE cognitives seraient associées à l'efficience du cortex préfrontal dorsolatéral alors que les FE « hot » (résponsables de la régulation émotionelle, la prise de décision, et la cognition sociale) dépendraient des régions ventromédiane et orbitofrontale.

Ces troubles exécutifs, comportementaux et cognitifs, seraient indépendants du niveau d'intelligence, des compétences verbales et perceptives, et des capacités mnésiques se montrant souvent preservées (Anderson et al., 2000 ; Bonnier et al., 2010). De plus, les troubles cognitifs et comportementaux décrits après des lésions frontales chez les enfants sont souvent durables (Chen et al., 2013). Cette vulnerabilité précoce chez les enfants a été attribuée à une inflammation cérébrale plus prolongée chez les enfants par comparaison aux adultes (Claus et al., 2010; Tsuru-Aoyagi et al., 2009) et au statut immature et « en développement» du cerveau de l'enfant. En effet, une lésion au niveau du lobe frontal en développement impacterait l'acquisition de compétences nouvelles et mènerait potentiellement à une apparition retardée des troubles (Anderson et al., 2012).

L'épilepsie est l'un de ces contextes étiologiques pour lequel plusieurs travaux ont montré un syndrome dysexécutif précoce (Charbonnier et al., 2011 ; Culhane- 
Shelburne et al., 2002 ; Hernandez et al., 2002 ; Riva et al., 2005). Cette pathologie est considérée comme l'un des désordres neurologiques les plus fréquents durant l'enfance et toucherait autour de $1 \%$ des enfants âgés de 0 à 15 ans (Cowan, 2002). Bhalla et al. (2016) notent une prévalence de 7.5/1000 basée sur 21 études qui se sont déroulées dans 9 pays Arabes différents, mais pas au Liban. Les études qui ont été réalisées auprès de populations épileptiques pédiatriques libanaises s'intéressent principalement aux données médicales en lien avec les traitements chirurgicaux d'enfants épileptiques (Mikati et al. 2013), sans étudier réellement l'impact sur le développement cognitif et plus spécifiquement exécutif des enfants.

Par exemple, Mikati et al. (2013) ont évalué un échantillon d'enfants 2.5 ans après des résections chirurgicales focales. Bien que les auteurs s'intéressaient principalement à l'effet du traitement sur la fréquence des crises, ils ont également investigué la qualité de vie et les conséquences cognitives, sociales et comportementales des enfants en période post-chirurgicale. Cependant, leurs outils de mesure ne comprenaient que des questionnaires de qualité de vie, de sévérité des crises, et d'effets secondaires des traitements épileptiques. Afin d'évaluer l'impact cognitif, Mikati et al. (2013) ont utilisé des entretiens auprès des parents plutôt que des outils neuropsychologiques (par exemple : “Que pouvez-vous nous dire concernant l'état de l'attention, de la mémoire, et du langage de votre enfant ?'). Nous n'avons trouvé aucune étude libanaise publiée incluant une évaluation approfondie étudiant les conséquences cognitives, et plus spécifiquement dysexécutives, des traitements chirurgicaux des épilepsies focales chez des enfants libanais. Pourtant, cette pathologie engendre des conséquences délétères indéniables sur le développement des FE, d'autant plus dans les épilepsies focales frontales (Culhane-Shelburne et al., 2002; Hernandez et al., 2002; Lassonde et al., 2000).

En effet, l'épilepsie frontale impacterait le développement exécutif et entraînerait chez les enfants des troubles de la planification, de la MDT, du contrôle impulsif et de l'attention (Hernandez et al., 2002). Ces enfants montrent également des troubles du comportement, se caractérisant par un tableau dysexécutif pseudopsychopathique, et donc, une hyperactivité, une irritabilité, une impulsivité et des difficultés à contrôler leurs réactions émotionnelles (Braaman et al., 2011; Campiglia et al., 2014). L’impact du syndrome dysexécutif sur le quotidien des enfants avec ELF a été décrit par 
Campiglia et al. (2014) à travers l'utilisation d'un questionnaire d'évaluation des FE dans la vie quotidienne (BRIEF) qui a montré un dysfonctionnement global impactant le quotidien de l'enfant à la maison et à l'école. Les troubles des FE chez l'enfant avec ELF sont souvent durables, malgré le traitement chirurgical de l'épilepsie focale. En effet, le traitement chirurgical de l'ELF peut mener à une amélioration de la fréquence des crises mais être aussi responsable de conséquences délétères sur le fonctionnement exécutif de l'enfant (Chieffo et al., 2011). 


\section{ProblemATIQUE, OBJECTIFS ET}

\section{HYPOTHESES}

\subsection{Objectif et Problématique}

Diamond (2013) propose un modèle intégratif hiérarchisé qui illustre la dynamique de développement des FE de l'enfance à l'adolescence et les inter-relations entre la MDT, l'inhibition, la flexibilité mentale et les fonctions de plus haut niveau, telle que la planification. Cependant, ce modèle ne prend pas en compte les influences culturelles et sociodémographiques susceptibles d'influencer le développement des FE. Plusieurs facteurs sociodémographiques tels que le genre, le niveau d'éducation parental, le niveau socio-économique, ou les compétences langagières, sont pourtant susceptibles d'influencer le développement des FE de la petite enfance à l'âge adulte (Ardila et al., 2005 ; Bellaj et al., 2015; Bialystok \& Viswanathan, 2009 ; Sabbagh et al., 2006). Malgré les données empiriques disponibles (Roukoz et al., 2018), peu d'études se sont intéressées à la question des FE dans le monde arabe (Bellaj et al. 2015).

En ce qui concerne le Liban, comme mentionné plus haut, on ne note aucune étude qui s'est intéressée au développement des FE au cours de la petite enfance ou de l'adolescence, ou à l'influence des facteurs culturels propres au pays. Pourtant, la question de l'influence des facteurs sociodémographiques au Liban semble primordiale dans la mesure où le Liban est un pays qui regroupe plus d'une dizaine de communautés religieuses associées chacune à des coutumes et modes de vie spécifiques. Cette hétérogénéité culturelle propre au Liban est susceptible d'entraîner des différences dans le développement des FE dans la population pédiatrique libanaise, compte tenu des constats relevés à travers certaines études conduites auprès de populations de groupes ethniques différents (Roukoz et al., 2018).

Ainsi, au regard des travaux empiriques (par exemple, Chasiotis et al., 2006 ; Lan et al., 2011 ; Lahat et al. 2010 ; Sabbagh et al., 2006), il apparaît aujourd'hui essentiel de poursuivre les recherches concernant l'influence des facteurs sociodémographiques et culturels sur le développement des FE. 
En outre, l'étude des FE en neuropsychologie clinique de l'enfant est récente mais représente actuellement un enjeu de santé déterminant, notamment parce que nombreux sont les cadres étiologiques concernés. Actuellement, au Liban, l'étude des FE auprès de la population clinique se base principalement sur des données normatives anglosaxonnes. La qualité, la sensibilité et la validité du bilan neuropsychologique tel qu'il est conduit par les professionnels libanais sont remises en question, dans la mesure où les épreuves ne sont ni adaptées à la culture, ni à la langue des patients (Ardila et al., 2005 ; Brickman et al., 2006 ; Boone, et al., 2007; Fernandez \& Marcopulos, 2008 ; Loewenstein et al., 1994). En effet, comme mentionné plus haut, plusieurs études (par exemple, Fernandez \& Marcopulos, 2008), ont montré le risque de "faux positifs" en comparant le score d'un individu à un test cognitif à des normes issues de pays avoisinants. Il semble donc primordial de disposer de données développementales normatives appropriées afin d'assurer un suivi adéquat de la population clinique pédiatrique au Liban.

Par ailleurs, comme nous avons pu le mentionner plus tôt, l'épilepsie est l'un de ces contextes étiologiques pour lequel plusieurs travaux ont montré un syndrome dysexécutif précoce (Charbonnier et al., 2011; Culhane-Shelburne et al. 2002; Hernandez et al., 2002 ; Riva et al., 2005). L'épilepsie représente de plus un désordre neurologique parmi les plus fréquents durant l'enfance, constituant un enjeu majeur de santé publique. Malgré la fréquence de cette pathologie chez les jeunes enfants et les conséquences développementales de l'épilepsie infantile, ce contexte étiologique reste très peu étudié au Liban, surtout dans une perspective développementale. Pourtant, cette pathologie engendre des conséquences délétères indéniables sur le développement des FE, d'autant plus dans les épilepsies focales frontales (Culhane-Shelburne et al., 2002; Hernandez et al., 2002; Lassonde et al., 2000), au vu du rôle central du cortex préfrontal pour la mise en jeu des FE. 
Plusieurs objectifs sont donc associés à cette thèse.

Objectif 1 :

Le premier objectif est de fournir des outils d'évaluation des FE adaptés à la population libanaise d'âge scolaire à travers l'adaptation du protocole FEE.

\section{Objectif 2 :}

Il s'agit également de préciser la dynamique développementale des FE, de 6 à 12 ans, chez les enfants libanais, au niveau de quatre domaines exécutifs tels que formalisés dans le modèle de Diamond (2013), à savoir l'inhibition, la MDT, la flexibilité mentale et la planification.

\section{Objectif 3 :}

Il s'agit, ensuite, de questionner l'influence des facteurs sociodémographiques (genre et niveau d'éducation parental) dans le contexte Libanais, sur le développement des FE, questionnement qui n'est pas intégré dans les modélisations actuelles mais qui est, pourtant, désormais largement débattu dans la littérature (Ardila et al., 2005 ; Bellaj et al., 2015 ; Bialystok, 1999 ; Sabbagh et al., 2006). Ces données nous permettront donc de réfléchir les modélisations actuelles, tel que le modèle de Diamond (2013), qui s'inscrit actuellement dans une perspective universaliste.

\section{Objectif 4 :}

Enfin, le dernier objectif est de mener une application clinique auprès d'un enfant avec une épilepsie focale à travers l'utilisation de la batterie FEE adaptée en langue Arabe. Cette application clinique permettra de récolter des données préliminaires quant à la sensibilité des tâches exécutives adaptées en langue Arabe, dans le contexte libanais, et apporter des informations permettant d'affiner la pratique clinique auprès de cette population. 


\subsection{Hypothèses}

Sur la base des données internationales disponibles, les hypothèses de travail sont les suivantes :

\section{Hypothèse 1 :}

Nous nous attendons à un effet de l'âge sur les quatre domaines des FE évalués (l'inhibition, la flexibilité mentale, la MDT et la planification) entre 6 et 12 ans chez les enfants libanais tel qu'ils sont proposés dans le modèle intégratif de Diamond (2013). Les enfants libanais montreront donc une amélioration de leurs performances aux tâches de FE entre 6 et 12 ans.

\section{Hypothèse 2 :}

Nous nous attendons à une influence significative du niveau d'étude de la mère et du niveau d'étude du père sur le développement des FE (Ardila el al. 2005; Last et al., 2018) et à un effet non-significatif du genre (Arán-Filippetti \& Allegri, 2011; Armengol, 2002; Brocki \& Bohlin, 2004; Welsh et al., 1991). En ce qui concerne le niveau d'éducation parental, nous nous attendons à une association positive du niveau d'éducation parental et des performances aux tests de FE: plus le niveau d'éducation maternel et paternel est élevé, plus les performances aux tests de FE seront élévées (Ardila et al., 2005; Last et al., 2018).

Hypothèse 3 :

Dans le contexte d'une étude préliminaire de validité et de sensibilité clinique du protocole FEE adapté au contexte libanais, nous faisons l'hypothèse que des troubles de planification, de MDT, d'inhibition et de flexibilité seront retrouvés chez un enfant présentant une pathologie impliquant le lobe frontal, dans ce cas, une ELF (CulhaneShelburne et al. 2002 ; Hernandez et al.,2002; Lassonde et al., 2000). 


\section{METHODOLOGIE}

\subsection{PARTICIPANTS}

La population ayant participé à cette étude était initialement composée de 110 enfants Libanais âgés entre 6 et 12 ans. Les enfants étaient inclus dans l'étude à condition qu'ils soient Libanais, qu'ils fréquentent une école privée libanaise, qu'ils aient une bonne maîtrise de la langue Arabe, et qu'ils ne présentent pas d'antécédents psychiatriques ou neurologiques, de troubles neurodéveloppementaux, de troubles sensoriels ou des troubles d'apprentissage. Les enfants étaient également inclus à condition que leurs parents consentent à leurs participations à cette étude en signant une notice d'information et un formulaire de consentement delivrée en Arabe (Annexe 3). Les critères d'inclusion et d'exclusion ainsi que les données sociodémographiques (genre, type d'école, niveau d'éducation maternel et paternel, métier des parents etc.) ont été recueillies à travers l'utilisation d'un questionnaire administré aux parents. Le questionnaire comportait des questions développementales au sujet par exemple $d u$ déroulement de la grossesse ou des antécédents médicaux de l'enfant, ainsi que des questions fermées au sujet des rendements scolaires de l'enfant ou de son comportement actuel (Annexe 4).

L'ensemble des enfants étaient droitiers et bilingues (fluents en Arabe et en Français ou en Arabe et en Anglais). Le bilinguisme a été vérifié à travers l'utilisation du questionnaire PaBiQ (Questionnaire pour parents d'enfants bilingues). Ce questionnaire est une traduction/adaptation du Questionnaire Parents of Bilingual Children (COST Action IS0804, 2011). Il est rempli par l'examinateur sur la base d'un entretien mené avec les parents. Les questions posées évaluent l'âge du premier contact à différents langages, la fréquence d'utilisation des différentes langues ainsi que les compétences langagières de l'enfant bilingue ou trilingue (Annexe 6). Les enfants étaient exclus de l'étude s'ils présentaient des difficultés scolaires (présence d'auxiliaire de vie scolaire ou de programme scolaire individualisé), des troubles neurodéveloppementaux, des antécédents de pathologies neurologiques ou psychiatriques, des troubles sensoriels, une maîtrise insuffisante de la langue Arabe, ou le non-consentement des parents pour la participation à l'étude. Les enfants étaient également exclus de l'étude s'ils présentaient un score standard inferieur à 6 aux 
épreuves de « Matrices » et «Vocabulaire » du test Wechsler Intelligence Scale for Children-Fourth Edition- version Arabe (WISC-IV - Arabe).

Dix enfants ont été exclus de l'étude. Trois ont été exclus en raison d'une grande agitation comportementale durant la passation, limitant leur participation et interrogeant la présence d'un TDA/H. Un enfant a été exclu de l'étude parce qu'il a refusé de compléter l'ensemble des tâches et un autre a été exclu parce que la famille a émigré du Liban avant la date prévue de la passation des tests. Enfin, 5 enfants ont été exclus parce qu'ils ont montré un score insuffisant aux tâches de «Matrices » et «Vocabulaire», questionnant des troubles dans les fonctions cognitives non exécutives.

La population restante était composée de 100 enfants libanais recrutés dans des écoles privées, lesquelles sont généralement fréquentées par des enfants issus de familles appartenant à un niveau socio-économique moyen. Les enfants ont été recrutés dans trois régions libanaises: Beyrouth $(\mathrm{N}=30)$, Mont Liban $(\mathrm{N}=40)$ et Sud du Liban $(\mathrm{N}=30)$. Les données socio-démographiques de la population sont présentées dans la Table 5.

Table 5: Répartition des enfants Libanais par catégories d'âges, genre, niveau d'éducation maternel et niveau d'éducation paternel.

\begin{tabular}{cccccc}
\hline $\begin{array}{c}\text { Catégories } \\
\text { d'âge }\end{array}$ & & 6-7 (N=22) & $8-9(\mathrm{~N}=38)$ & $\begin{array}{c}10-12 \\
(\mathrm{~N}=40)\end{array}$ & $\begin{array}{c}\text { Total } \\
(\mathrm{N}=100)\end{array}$ \\
\hline Genre & Filles & 11 & 17 & 26 & 54 \\
& Garçons & 11 & 21 & 14 & 46 \\
\hline Niveau & $<12$ & 4 & 8 & 16 & 28 \\
d'éducation & $>15$ & 18 & 30 & 24 & 72 \\
maternel & $<12$ & 7 & 13 & 22 & 42 \\
\hline $\begin{array}{c}\text { Niveau } \\
\text { d'éducationnel } \\
\text { paternel }\end{array}$ & $>15$ & 15 & 25 & 18 & 58 \\
\hline
\end{tabular}

\subsection{Matériel}

Les outils utilisés pour l'évaluation des FE étaient basés sur le protocole FEE (Fonctions Exécutives de l'Enfant) qui consiste en une batterie expérimentale évaluant l'inhibition, la flexibilité mentale, la planification, et la MDT sur le versant verbal et non-verbal tout en contrôlant les processus de supports (voir : «L'évaluation des FE chez l'enfant» p.55 pour une description du protocole FEE). Huit des 12 tests du 
protocole FEE ont été inclus dans cette étude. Quatre tests ont été exclus afin de raccourcir le protocole qui durait initialement 3 heures, tout en assurant une évaluation de chaque FE dans différentes modalités, verbale et non-verbale. La Table 6 présente les sous-tests de la batterie FEE qui ont été adaptés et administrés à la population Libanaise.

Table 6: Présentation et description des tests issus de la batterie FEE et inclus dans le protocole libanais

\begin{tabular}{|c|c|c|}
\hline $\mathrm{EF}$ & Test & Description \\
\hline \multirow[t]{2}{*}{ Inhibition } & Stroop & $\begin{array}{l}\text { Le test Stroop comporte } 3 \text { planches. La première planche est composée de rectangles } \\
\text { de couleur que l'enfant doit dénommer en Arabe. La deuxième planche est composée } \\
\text { de noms de couleur écrits à l'encre noire que l'enfant doit lire en Arabe. Enfin, dans la } \\
\text { troisième planche, il est demandé au sujet de nommer la couleur avec laquelle est écrit } \\
\text { un mot, mais le mot désigne une couleur qui n'est pas celle de l'impression. Par } \\
\text { exemple, le mot « vert » peut être écrit en bleu. }\end{array}$ \\
\hline & Tapping & $\begin{array}{l}\text { Ce test comporte } 3 \text { conditions. Dans la première partie du test, l'enfant doit taper sur } \\
\text { la table le même nombre de fois que l'examinateur. Dans la deuxième partie du test, } \\
\text { l'enfant doit taper une fois si l'examinateur tape deux fois et deux fois si l'examinateur } \\
\text { tape une fois. Dans la dernière partie du test, l'enfant doit suivre les instructions } \\
\text { précédentes et en parallèle, si l'examinateur tape avec les deux doigts, l'enfant ne doit } \\
\text { pas taper. }\end{array}$ \\
\hline \multirow[t]{2}{*}{$\begin{array}{l}\text { Mémoire de } \\
\text { Travail }\end{array}$} & $\begin{array}{l}\text { Mise à jour } \\
\text { Visuospatiale }\end{array}$ & $\begin{array}{l}\text { Il est demandé à l'enfant de rappeler les localisations des } 3 \text { ou } 4 \text { derniers cubes d'une } \\
\text { séquence. }\end{array}$ \\
\hline & $\begin{array}{l}\text { Mise à Jour } \\
\text { verbale }\end{array}$ & Il est demandé à l'enfant de rappeler les 3 ou 4 dernières lettres d'une séquence. \\
\hline \multirow[t]{2}{*}{ Flexibilité } & $\begin{array}{l}\text { Trail Making } \\
\text { Test (TMT) }\end{array}$ & $\begin{array}{l}\text { Il est demandé à l'enfant de compléter } 3 \text { conditions. D'abord, l'enfant doit relier les } \\
\text { cercles comprenant des chiffres, dans l'ordre croissant. Dans la deuxième condition du } \\
\text { test, il doit relier les lettres dans l'ordre alphabétique, ensuite, l'enfant doit relier les } \\
\text { cercles en switchant d'une lettre à un chiffre dans l'ordre croissant des chiffres et de } \\
\text { l'alphabet. Les chiffres et les lettres sont présentées en Français. }\end{array}$ \\
\hline & $\begin{array}{lr}\text { Kids } & \text { Card } \\
\text { Sorting } & \text { Test } \\
(\text { KCST }) & \\
\end{array}$ & $\begin{array}{l}\text { Dans ce test, l'enfant doit classer des cartes selon différents critères qui lui sont donnés } \\
\text { (couleur, nombre, forme) et switcher d'un critère à un autre selon le feedback de } \\
\text { l'examinateur. }\end{array}$ \\
\hline \multirow[t]{2}{*}{ Planification } & $\begin{array}{l}\text { Test de } 8 \\
\text { Labyrinthes }\end{array}$ & L'enfant doit compléter 8 labyrinthes de complexité croissante. \\
\hline & $\begin{array}{l}\text { Figure } \\
\text { Rey }\end{array}$ & $\begin{array}{l}\text { L'enfant doit copier la figure de Rey, d'abord spontanément, ensuite avec une aide à } \\
\text { la planification. }\end{array}$ \\
\hline
\end{tabular}

L'ensemble des tests a subi une procédure de Translation and Back translation afin de traduire et d'adapter les tests de la langue Française à la langue Arabe (Borsa et al., 2012; International Test Commission, 2017). La figure 4 présente les différentes étapes à suivre selon les recommandations de Borsa et al. (2012). Dans un premier temps, les épreuves ainsi que leurs consignes ont été traduites par des experts neuropsychologues et linguistes marocains fluents dans les deux langues. Par la suite, une traduction inverse par d'autres psychologues et linguistes a été réalisée afin de vérifier si la version 
traduite correspondait bien aux consignes de la langue source. Cette étape permet d'assurer la stabilité des consignes du test. Enfin, une étude pilote a été réalisée auprès de 10 enfants libanais permettant d'examiner la fiabilité de la traduction. Les résultats de l'étude pilote ont été analysés par deux experts orthophonistes libanais qui ont suggéré certaines modifications dans la consigne du KCST (le mot « catégories » ainsi que le mot « règle » en Arabe ont été modifiés). Par la suite, et basé sur l'étude pilote, un supplément du manuel de passation a été imprimé présentant les instructions en Dialecte Libanais plutôt qu'en Arabe Standard Moderne (version de l'Arabe souvent difficile à comprendre par les enfants libanais). Sur la base de cette étude pilote, certains mots des consignes ont parfois dû être couplés à leurs équivalents dans une autre langue, notamment le nom des formes dans l'épreuve KCST. Par la suite, 5 étudiantes inscrites en Master 2 de Psychologie Clinique de 1'Université Saint-Joseph de Beyrouth ont été recrutées et formées à la passation des 8 tests inclus dans le protocole. 


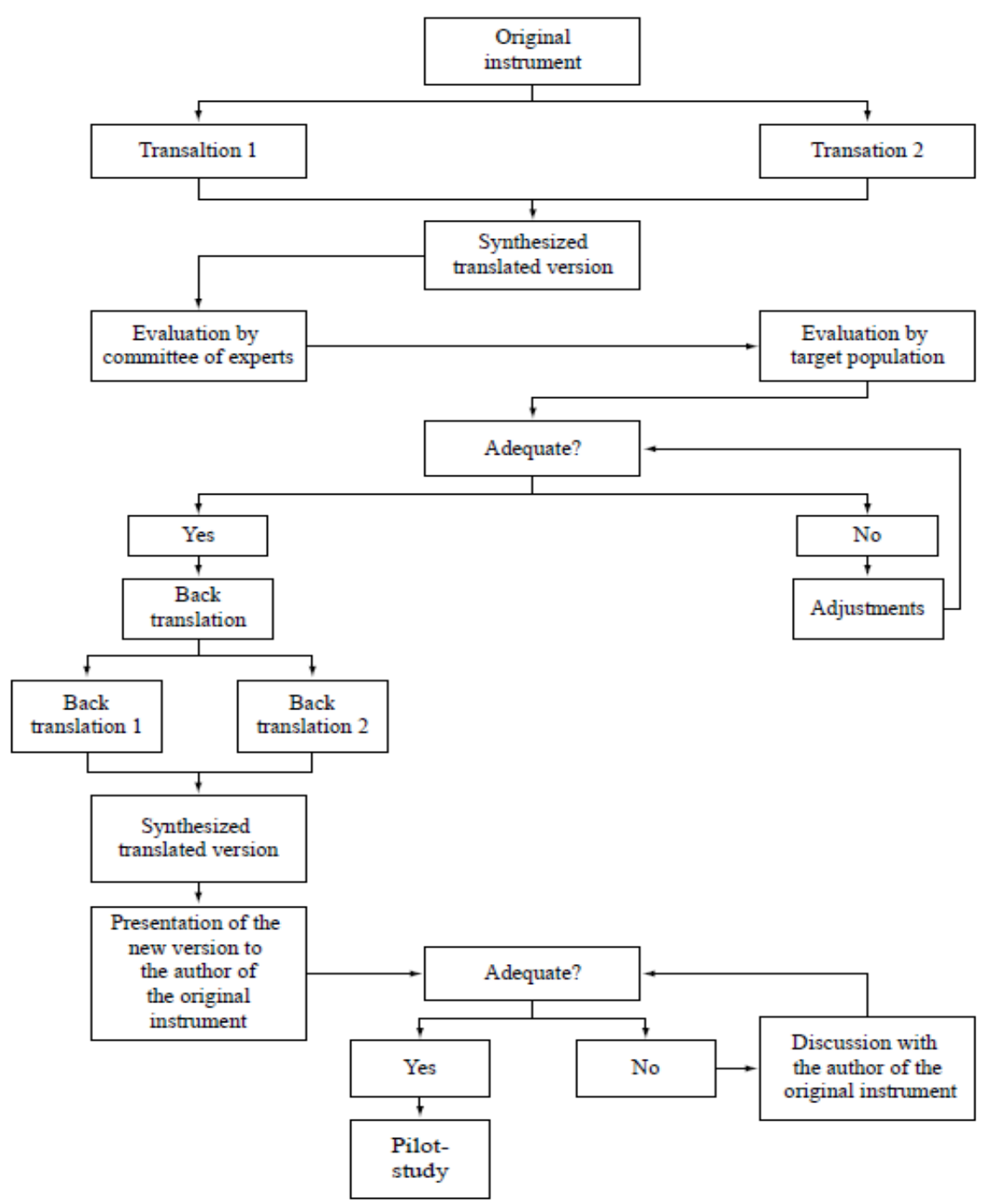

Fig.4 : Les différentes étapes nécessaires à l'adaptation d'un outil de sa langue d'origine à sa langue cible. Source : Borsa, Damásio, \& Bandeira (2012).

\subsection{Procédure}

Chaque enfant a été évalué à son domicile, un samedi ou dimanche, jours de congé scolaire au Liban. Une seule séance a été menée avec chaque enfant et cette dernière a duré entre $1 \mathrm{~h} 15$ minutes et $2 \mathrm{~h} 15$ minutes. Les enfants ont bénéficié d'une longue pause au milieu de la séance. L'ensemble des passations a suivi la même procédure et les tests ont été administrés dans le même ordre, fixé selon l'ordre de passation initialement proposé par le protocole FEE (Test de 8 Labyrinthes, Stroop, Mise à Jour Visuospatiale, Tapping, Figure de Rey, TMT, KCST, Mise à Jour Verbale).

Par la suite, 3 enfants avec ELF ont été évalués. Ces enfants ont été recrutés au sein d'un centre hospitalier privé à Beyrouth et ont été initialement référés au service de Neuropsychologie pour une évaluation post-chirurgicale. Les parents des enfants ainsi 
que le service hospitalier ont donné leur accord de poursuivre l'évaluation des enfants en y ajoutant les tests du protocole FEE. Cependant, deux des trois enfants montraient une déficience intellectuelle modérée à sévère et des difficultés majeures pour comprendre les consignes et compléter les épreuves du protocole. Un seul enfant a complété l'ensemble du protocole et a permis l'étude d'un cas clinique présenté dans le chapitre 7 de cette thèse.

Dans le chapitre 6 , nous présentons la première étude exposant les données du développement typique des FE chez les enfants libanais. Ensuite, dans le chapitre 7, nous présenterons l'analyse du cas clinique. 


\section{ETUde 1: DEVELOPPEMENT DES FE}

\section{AUPRES DE LA POPULATION LIBANAISE}

Ce chapitre présente le manuscrit suivant:

Roukoz, C., Guerra, A., Le Gall, D. \& Roy, A. Development of Executive Functions in Lebanese Children. Manuscript under review.

Soumis le 04 Septembre 2020 à la revue Developmental Neuropsychology 


\title{
Development of Executive Functions in Lebanese Children
}

Cynthia Roukoz ${ }^{\mathrm{a}}$, Amanda Guerra $^{\mathrm{b}}$, Didier Le Gallc ${ }^{\mathrm{c}}$, Maria Ghazi ${ }^{\mathrm{d}}$ and Arnaud Roy ${ }^{\mathrm{e}}$

${ }^{a}$ Psychiatry department, American University of Beirut Medical Center; ${ }^{b}$ Laboratoire de Psychologie des Pays de la Loire, Université d'Angers; 'Laboratoire de Psychologie des Pays de la Loire, Université d'Angers; 'Saint-Joseph University of Beirut, Department of Psychology; 'Laboratoire de Psychologie des Pays de la Loire, Université d'Angers.

\author{
ARTICLE HISTORY \\ Compiled October 1, 2020
}

\begin{abstract}
The current study focused on adapting EF tests for children to the Arabic language and examine the developmental trajectories of school-aged Lebanese children in four domains of EF (inhibition, flexibility, working memory, and planning). It also focused on examining the effects of gender and parent's education level on EF performance. The study population included 100 Lebanese children aged from 6 to 12 -years old who were grouped and matched for age, gender, and parental level of education. Results revealed a main effect of age and level of education of parents while the effect of gender was non-significant.
\end{abstract}

KEYWORDS: Executive functions, development, Culture.

CONTACT Cynthia Roukoz: Email: cr21@aub.edu.lb

Email: adlbguerra@hotmail.com (Amanda Guerra)

Email: didier.legall@univ-angers.fr (Didier Le Gall)

Email: mariagh119@gmail.com (Maria Ghazi)

Email: arnaud.roy@univ-angers.fr (Arnaud Roy) 


\section{INTRODUCTION}

Executive functions (EFs) can be defined as a set of higher-level cognitive skills that underlie goal-directed behavior (Luria, 1966). According to Diamond (2013), these functions are defined as a collection of top-down control processes used when an automatic or instinctive response is not sufficient to appropriately complete an ongoing task. There is a general agreement that there are three main-postulated core EFs: inhibition control, working memory, and cognitive flexibility (e.g., Lehto et al., 2003, Miyake et al., 2000). It is also well established that EF consists of independent but interrelated components (Miyake et al., 2000) and that the development of EFs in childhood and into adulthood is non-linear and non-synchronous (e.g., Dennis, 2006; Diamond, 2013).

Various studies showed signs of EF development from early childhood up to adulthood. Emerging signs of inhibition were observed in early infancy and preschool years (Klenberg et al., 2001; Lehto et al., 2003) with continuous development of some skills up to adolescence (Brocki \& Bohlin, 2004). Regarding working memory development, it has been shown to continuously develop until adolescence for both verbal and visuospatial components (Best et al., 2009; Gathercole et al., 2004; Luciana et al., 2005). Studies also suggested a prolonged development up to teenage of cognitive flexibility (Davidson et al., 2006; Huizinga et al., 2006) and planning abilities (Huizinga et al., 2006; Luciana \& Nelson, 1998).

Diamond (2013) suggests a progressive differentiation of EF components throughout preschoolers and school-aged children with a hierarchical development of different EF components. Diamond (2013) seems to suggest an earlier differentiation of inhibition and working memory when compared to other EF components and relying on those pillars, flexibility along with other higher-order EFs would gradually emerge. Factorial studies converge with the latter, showing unitary models of EF before the age of 5 with age-related differences and emerging of structures showing two and three well-separated yet interdependent factors throughout school years and up to adolescence (Lee et al., 2013).

While such models draw interesting theoretical illustration of EF development, they seem relatively reductionist as they account mainly for age to better understand developmental changes in EF, while many studies suggest cultural and sociodemographic influence in children's early development of cognitive control skills (Berlin \& Bohlin, 2002; Chasiotis et al., 2006; Lahat et al., 2010; Lan et al. 2011; Pena et al., 2002; Sabbagh et al., 2006). Indeed, culture and its link to cognitive growth has been a topic of interest for a long time and decontextualizing psychological and cognitive development raises a number of problems (Bruner, 1966). For instance, studies seem to suggest better EF development in East Asian children when compared to American and European children (Sabbagh et al., 2006; Rubin et al., 2006; Lan et al., 2011).

Even within a same culture, studies have been suggestive of many sociodemographic factors influencing the development of EF in children (Ardila et al., 2005; Armengol, 2002; Arán-Filippetti \& Allegri, 2011; Bellaj et al., 2015; Brocki \&

Roukoz Cynthia | Développement des Fonctions Exécutives chez les Enfants 
Bohlin, 2004; Hurks et al., 2010; Welsh et al., 1991). For instance, the effect of gender on executive development is largely investigated but findings remain inconclusive and no consensus is reached. Some authors report more efficient cognitive development in girls (Ardila, et al., 2005), others report better functioning in boys (Halpern, 2000), whereas most studies have found non-significant effect of gender (Filippetti \& Allegri, 2011; Armengol, 2002; Brocki \& Bohlin, 2004; Welsh et al., 1991). Similarly, parental level of education and socio-economic status have been suggested to be positively related to EF development (Ardila et al., 2005; Last et al., 2018).

Despite the growing body of literature showing evidence of an effect of cultural and demographic variables on the development of EF, several environmental contexts remain unexplored. There are no studies, except one from Bellaj et al. (2015), that looks at the development of EF in Arabic-speaking children. This one showed a significant effect of age and level of education of parents and a non-significant effect of gender on EF performance in Tunisian children aged 8 to 12 . At this point, no studies in the literature searching several databases (PubMed, SAGE, Science Direct, Jstor, Oxford University Press, Psychology \& Behavioral Sciences, Persée, Web of Science, Hypotheses.org, Revues.org, Cairn and Psycarticles) were found on Middle-eastern children. Lebanon is one of those contexts that lack such studies.

Lebanon is a country with a heterogeneous population, whether regarding language proficiency, religions, values, and socioeconomic status. Indeed, there are 18 registered religions in Lebanon and Lebanese citizens are typically distributed geographically depending on their religion. Each religion typically comes with different sociocultural habits and educational values. Some are more conservative while others value a more western way of living. Also, while Arabic is Lebanon's official language, English and French constitute the languages of instruction in most private and public schools. Some parents will therefore prioritize a foreign language (either French or English) as the child's first language whereas others will use Arabic as their primary means of communication leading to heterogeneity in children's language proficiencies. Lebanon is a country with an unfortunate history of wars and political and economic instabilities. Therefore, many Lebanese families have emigrated from Lebanon throughout the years and the current Lebanese diaspora is estimated to be around 13 million Lebanese living abroad while 4 million Lebanese reside in Lebanon (Tabar, 2009).

On the other hand, the lack of local studies on children's development leads to a significant impact on clinical services needed by Lebanese children. There are, to date, no tools adapted to the Arabic language and to the Lebanese population permitting the assessment of EF among Lebanese children. The lack of tools is currently being compensated for by using tests and norms intended for American or French children which poses a wide range of problems and questions the validity of the evaluation conducted (Ardila, 2005; Boone et al., 2007; Brickman et al., 2006; Fernandez \& Marcopulos, 2008; Loewenstein et al., 1994). 
Therefore, the main aim of this study was to examine the developmental trends of four components of EF, namely inhibition of prepotent responses, cognitive flexibility, working memory, and planning, among a sample of 6- to 12-year-old Lebanese children using performance-based neuropsychological tasks adapted to the Lebanese population. The second objective includes the assessment of the potential effects of three usual sociodemographic factors being gender, mother's level of education, and father's level of education on the development of EF.

\section{METHODS}

\section{Participants}

A total of 110 Lebanese children aged from 6 to 12 participated to the study. All of the children were right-handed. The entire sample was bilingual, fluent in both Arabic and a foreign language (either French or English) before the age of 5, assessed through a socio-demographic questionnaire intended to parents. The sample was collected through convenient sampling across Beirut, South Lebanon and Metn region in Lebanon. The children were selected as long as they were healthy and had no neurological or psychiatric history, sensory impairments, neurodevelopmental disorders or learning difficulties, were aged from 6 to 12, and had a sufficient knowledge of the Arabic language. The exclusion and inclusion criteria were verified through the use of a questionnaire filled out by parents prior to their selection. The recruitment of children was made in several private schools attended mostly by children belonging to a middle socio-economic class. Written parental consent and informed participant consent was obtained prior to test administration.

Among the 110 children recruited, 10 were excluded from the study: 3 were excluded due to severe behavioral dysregulation and hyperactivity throughout the testing sessions and therefore suspected undiagnosed Attention Deficit/Hyperactivity Disorder, 1 was excluded as he refused to engage in the tests, 1 was excluded because the family immigrated before the child was seen for testing and the remaining 5 were excluded due to a lack of understanding of instructions and major difficulties completing proposed tasks. The remaining sample was composed of 100 children aged from 6 to 12. Fifty-four were females and 46 were males. Groups were categorized in three age groups: 6-7, 8-9, 10-12. Level of education of mother and father were also categorized in two groups as followed: $<12$ (high school degree or less) or $>15$ (university degrees).

The age groups were equivalent in terms of mother's and father's education level (respectively: $\mathrm{F}(2,100)=2,084, \mathrm{p}=.130 ; \mathrm{F}(2,100)=2,269, \mathrm{p}=.099)$, and in terms of gender $(\mathrm{F}(2,100)=1.709, \mathrm{p}=.187)$. Also, gender groups were equivalent in terms of level of education of mother $(\mathrm{F}(1,100)=0.426, \mathrm{p}=.515)$, and level of education of father $(\mathrm{F}(1,100)=1.177, \mathrm{p}=.281)$. On the other hand, groups for level of education of mother were different from groups of level of education of father $(F(1,100)=19,148, p$ $=<.001)$.

Table 1 shows the demographic data for the study population. 
Table 1. Demographic Data

\begin{tabular}{cccccc}
\hline Age category & & $6-7(\mathrm{~N}=22)$ & $8-9(\mathrm{~N}=38)$ & $10-12(\mathrm{~N}=40)$ & Total (N=100) \\
\hline Gender & Girls & 11 & 17 & 26 & 54 \\
$\begin{array}{c}\text { Level of } \\
\text { education } \\
\text { mother }\end{array}$ & Boys & 11 & 21 & 14 & 46 \\
$\begin{array}{c}\text { Level of } \\
\text { education } \\
\text { father }\end{array}$ & $>12$ & 4 & 8 & 16 & 28 \\
\hline
\end{tabular}

\section{Materials}

The materials used for assessing EF was based on the Child Executive Functions Battery (CEF-B), which, established on a child-centered theoretical model, assesses the main executive processes: inhibition, flexibility, working memory and planning (Diamond, 2013). The CEF-B consists of a set of 12 tests for the neuropsychological evaluation of EF aimed at French children and adolescents between 6 and 16 years old (Roy, 2015). Some of the tests included in the CEF-B are new experimental tasks and others such as the Stroop test or the Trail Making Test already exist in the international literature but have been modified to better suit children. In this study, eight of the twelve tests of the CEF-B were adapted to the Arabic language and to the Lebanese population. Each two tests preferentially assess one of the four EF components. Table 2 presents the description of EF tests adapted to the Arabic language. Standardized instructions were given to children in the Lebanese dialect, on the basis of the instructions in Modern Standard Arabic resulting from the adaptation of the tool to the Arabic language.

The tools, initially in French, underwent a translation/back-translation procedure carried out by relevant experts following the recommendations of Borsa et al. (2012) and the International Test Commission (ITC, 2016). As recommended by Borsa et al. (2012), a first translation from French to Arabic was completed by two relevant experts who were fluent in both French and Arabic. The two versions were synthetized into one, evaluated by a committee of experts before moving to the back translation of the material, which was also conducted by two relevant experts and synthetized afterwards. The tests were then administered to a pilot group comprising 10 Lebanese children and some instructions were slightly modified accordingly. It should be noted that in the Stroop test, color names were required in Arabic. On the other hand, for the Trail Making Test and Verbal Updating tests, which involve letters/numbers, numbers and letters were presented in French or English, given the greater command, among bilingual Lebanese children, of the alphabet and numbers in French or English. 
Table 2. Description of tests included in the Arabic adaptation of the CEF-B

\begin{tabular}{ll} 
EF & Test \\
\hline Inhibition & Stroop test
\end{tabular}

\section{Description}

An Arabic adaptation of the Stroop Test was conducted. The test consists of three parts that the child must complete as quickly as possible. In Part A the child is required to name the color of each rectangle. In Part B, the child is required to read each word. In Part $\mathrm{C}$, color names are written in a different ink color than the written word and the child is required to name the color rather than read the word.

Child Tapping The test is divided into three parts. In Part A, the examiner taps on
test the table with his index finger either once or twice; the child is required to imitate the examiner in each case. In Part $\mathrm{B}(\mathrm{Go} / \mathrm{No}-$ Go), the child is required to tap once if the examiner taps once and refrain from tapping if the examiner taps twice. In Part $\mathrm{C}$ (Conflict Conditioning and Go/No-Go), the child should tap twice if the examiner taps once and, inversely, tap once if the examiner taps twice. In parallel, if the examiner taps with two fingers, whether once or twice, the child should refrain from responding.

\begin{tabular}{|c|c|c|}
\hline $\begin{array}{l}\text { Working } \\
\text { memory }\end{array}$ & $\begin{array}{l}\text { Visuospatial } \\
\text { Updating test }\end{array}$ & $\begin{array}{l}\text { Visual Updating Test consists of two parts in which the examiner } \\
\text { uses a board on which are placed ten cubes. Based on the child's } \\
\text { visual spatial span, the basal will be determined. In the second part } \\
\text { of the test (Updating), the examiner points at cubes sequentially; } \\
\text { the child is required to recall, in order, the location of the last } 3 \text { or } \\
4 \text { cubes (depending on his baseline score). The sequences may } \\
\text { require } 0 \text { updates (R0 sequences), } 2 \text { updates (R } 2 \text { sequences), or } 3 \\
\text { updates (R3 sequences). }\end{array}$ \\
\hline
\end{tabular}

Verbal Verbal Updating Test is similar to Visuospatial Updating Test but

Updating test assesses verbal working memory, using sequences of letters that are read to the child rather than block locations.

Flexibility Trail Making In this task, the child is asked to perform, as quickly as possible, Test (TMT) three test conditions. In Part Ac, the child is required to connect the circles by following an ascending order. In Part Al the child is required to connect the circles following the alphabetical order of letters. In Part B, the child is required to connect circles by alternating between numbers and letters in sequence.

Kids Card In this adaptation of the WCST, four reference cards are placed in Sorting Test front of the child. The examiner then shows 48 cards, one by one, (KCST) to the child. The child is required to associate each card presented to him with one of the four reference cards by matching the cards on the basis of shape, color or number. In the case of a correct classification, the examiner says "yes" and the child should continue classifying them in the same way; otherwise, the examiner says "no", and the child should then change his way of classifying the cards.

Planning 8 Mazes Test The test comprises eight mazes of increasing difficulty.

\section{Variable}

*Completion time of condition $\mathrm{C}$ - Completion time $\mathrm{A}$

*Numbers of errors $\mathrm{C}$ - Number of errors A.

The higher the scores, the greater the inhibition difficulties of the child.

*Completion time condition B - Completion time condition A

*Total numbers of errors in condition $\mathrm{B}$

*Completion time condition $\mathrm{C}$ - Completion time condition A

*Total number of errors in conditions B and C.

The higher the scores, the greater the inhibition difficulties.

*Total number of recalled locations on the baseline items *The cognitive charge score calculated using the following formula: (1-(score on items R $2+$ score on items $\mathrm{R} 3) /(2 *$ score on items R0) $) * 100$. The highest the score, the more impaired the working memory.

*The performance score which is calculated using the following formula: score on items R0 + score on items R2 + score on items R3. The lower the score the worse the working memory.

Same

*Flexibility index: completion time part B - (completion time condition A numbers + completion time condition A letters)/2)

The higher the score the more impaired the cognitive flexibility

*KCST completion time (in seconds)

* Number of perseverative errors

The higher the completion time and number of errors the greater the flexibility difficulties.
Rey Complex First part comprises a spontaneous copy of Rey's figure. Then, the Figure Test

child is required to copy the figure with a planning aid (Rey's figure is fragmented into different parts that are shown to the child successively, so that he completes the figure progressively).
*Number of successfully completed Mazes (the higher the score the better the planning performance)

* Mean of latency time for the 8 mazes (time difference between the presentation of the maze and starting the tracing the response)

* Completion time mean of the 8 mazes (the higher the scores the more the planning difficulties)

* Mean of number of mistakes for all completed mazes weighted by numbers of impasse mistakes (the closer the score is to 1 , the greater the child's difficulties).

*Rey copy Planning Index (IP): $(\mathrm{P} * 100) / \mathrm{C}$

$\mathrm{P}$ is the total score of on Planning subtest and is out of 36 and $\mathrm{C}$ is the total score on the spontaneous copy of the Rey figure and is out of 36

The higher the IP score the more the planning difficulties. 


\section{Procedure}

Prior to the inclusion of a child, the child's oral consent was obtained as well as the parents' signature on a consent form (which was attached to an information notice), and basic information (e.g., demographic) were collected. Children were assessed individually outside of school hours in a calm room in their home environment. Tests were administered in Arabic Lebanese Dialects by Psychology Master students trained on the standardized administration of the tests throughout several sessions. The session lasted between one hour-fifteen minutes and two hours-fifteen minutes depending on the child. Children were administered tests following standardized procedures and all children benefitted from a break towards the middle of the testing procedure. The battery of tests was administered to all children in the same sequence ( 8 Mazes test, Stroop test, Visuospatial updating test, Child Tapping test, Rey Complex Figure Test, TMT, KCST, Verbal updating test).

\section{Statistical Analysis}

The scores obtained in the various tests were subjected to statistical analysis using SPSS v.20.0. The Kolmogorov-Smirnov test revealed that the data was not normally distributed. We therefore carried out a data normalization process using parametric statistical tools. To test the effect of age and gender on EF performance, we used twoway analysis of variance (ANOVA) followed by an assessment of the weight of the effect by means of partial eta squared to study the effects of age and gender on EF performance. When the effects were significant, we used the Tukey HSD post hoc test to refine the results. We used t-tests to test the effect of level of education of mother and level of education of father on EF performance. For all analyses, the significance level for $p$ was set at .05. The descriptive data of the EF measures for each group age along with the $p$ values for age effect are presented in Table 3. The descriptive data for executive indices by gender and the p-values for gender effects are presented in Table 4. Finally, the descriptive data for executive indices by level of education of parents along with the $t$ values for the effects of mother and father's level of education are presented in Table 5.

\section{RESULTS}

\section{Inhibition}

Two-way analysis of variance (Age $\mathrm{x}$ gender) revealed a main effect of age on Tapping Conflicting Time and Tapping Conflicting Error. Post hoc analysis revealed, for Tapping Conflicting Time, a significant decrease of time between age groups 6-7 and 10-12 and for Tapping Conflicting Error, a decrease of numbers of errors was observed between the ages 6-7 and 8-9 and 6-7 and 10-12.

There was a significant effect of gender on the Tapping Go No Go completion time showing girls were faster than boys. No interaction was observed between gender and age on measures of inhibition.

Concerning the influence of parent's education, t-tests revealed a significant effect of mother's education level on Tapping conflicting errors showing that children

Roukoz Cynthia | Développement des Fonctions Exécutives chez les Enfants 
with mother's level of education $<12$ performed worse than those with mother's level of education $>15$. The other effects were non-significant.

Table 3. Descriptive Data for Executive Indices by Age and Age effects

\begin{tabular}{|c|c|c|c|c|c|c|c|c|c|c|}
\hline & \multicolumn{2}{|c|}{ Age group $6-7(\mathrm{~N}=22)$} & \multicolumn{2}{|c|}{ Age group 8 - $9(\mathrm{~N}=38)$} & \multicolumn{2}{|c|}{ Age group $10-12(\mathrm{~N}=40)$} & \multicolumn{3}{|c|}{ Analysis } & \multirow{2}{*}{$\begin{array}{c}\text { Post hoc } \\
\text { comparison }\end{array}$} \\
\hline & Mean & SD & Mean & SD & Mean & SD & $\mathrm{F}$ & $\mathrm{p}$ & $\eta 2$ & \\
\hline \multicolumn{11}{|l|}{ Inhibition } \\
\hline Stroop time & 61.32 & 75.92 & 86.42 & 39.98 & 76.30 & 32.22 & 2.949 & .057 & .059 & NS \\
\hline Stroop errors & 2.32 & 3.77 & 4.68 & 4.59 & 3.58 & 5.20 & 2.404 & .096 & .049 & NS \\
\hline $\begin{array}{c}\text { Tapping Go No Go } \\
\text { time }\end{array}$ & 7.68 & 9.86 & 6.26 & 16.15 & 6.40 & 9.78 & 1.334 & .268 & .028 & NS \\
\hline $\begin{array}{c}\text { Tapping Go No Go } \\
\text { errors }\end{array}$ & 0.91 & 1.15 & 0.76 & 0.91 & 0.53 & 0.72 & 1.674 & .193 &, 034 & NS \\
\hline $\begin{array}{c}\text { Tapping conflicting } \\
\text { time }\end{array}$ & 31.73 & 15.03 & 25.82 & 18.72 & 23.10 & 10.94 & 3.116 & $.049 *$ & .062 & $\begin{array}{l}6-7>10-12 \\
(p=0.017)\end{array}$ \\
\hline $\begin{array}{l}\text { Tapping conflicting } \\
\text { errors }\end{array}$ & 2.82 & 1.97 & 1.37 & 1.50 & 1.28 & 1.15 & 7.654 & $.001^{*}$ & .140 & $\begin{array}{c}6-7>8-9 \\
(p=0.001) \\
6-7>10-12 \\
(p=0.001)\end{array}$ \\
\hline \multicolumn{11}{|l|}{ Flexibility } \\
\hline $\begin{array}{l}\text { Trail Making Test } \\
\text { Flexibility Index }\end{array}$ & 53.05 & 98.56 & 37.66 & 44.96 & 22.36 & 28.81 & 2.598 & .080 & .052 & NS \\
\hline KCST Time & 362.41 & 90.48 & 333.33 & 93.33 & 245.14 & 55.70 & 20.422 & $<.001^{*}$ & .327 & $\begin{array}{l}6-7>10-12 \\
(p<0.001) \\
8-9>10-12 \\
(p<0.001)\end{array}$ \\
\hline KCST Perseverations & 4.23 & 4.12 & 2.70 & 4.94 & 2.59 & 2.51 & 1.887 & .158 & .043 & NS \\
\hline \multicolumn{11}{|l|}{ Working memory } \\
\hline $\begin{array}{c}\text { Verbal updating } \\
\text { baseline }\end{array}$ & 23.23 & 4.89 & 25.47 & 4.41 & 26.18 & 3.80 & 3.770 & $.027^{*}$ & .075 & $\begin{array}{l}6-7<10-12 \\
(p=0.009)\end{array}$ \\
\hline $\begin{array}{l}\text { Verbal updating } \\
\text { performance index }\end{array}$ & 38.63 & 12.75 & 44.20 & 11.84 & 44.92 & 11.11 & 1.337 & .268 & .030 & NS \\
\hline $\begin{array}{l}\text { Visual updating } \\
\text { baseline }\end{array}$ & 23.36 & 3.40 & 25.32 & 3.26 & 27.10 & 2.71 & 9.841 & $<.001^{*}$ & .175 & $\begin{array}{c}6-7<8-9 \\
(p=0.021) \\
6-7<10-12 \\
(p<0.001) \\
8-9<10-12 \\
(p=0.011)\end{array}$ \\
\hline $\begin{array}{c}\text { Visual updating } \\
\text { performance index }\end{array}$ & 19.36 & 11.24 & 26.61 & 9.28 & 29.10 & 9.27 & 6.414 & $.002^{*}$ & .122 & $\begin{array}{c}6-7<8-9 \\
(p=0.014) ; \\
6-7<10-12 \\
(p<0.001)\end{array}$ \\
\hline \multicolumn{11}{|l|}{ Planning } \\
\hline $\begin{array}{l}\text { Mazes completed } \\
\text { items }\end{array}$ & 7.00 & 1.72 & 7.84 & 0.49 & 7.88 & 0.33 & 5.207 & $.007^{*}$ & .100 & $\begin{array}{c}6-7<8-9 \\
(p=0.005) \\
6-7<10-12 \\
(p=0.006)\end{array}$ \\
\hline $\begin{array}{c}\text { Mazes completion } \\
\text { time }\end{array}$ & 147.65 & 59.78 & 110.68 & 36.48 & 85.40 & 32.90 & 10.580 & $<.001^{*}$ & .200 & $\begin{array}{c}6-7>10-12 \\
(p<0.001) \\
8-9>10-12 \\
(p=0.005)\end{array}$ \\
\hline $\begin{array}{l}\text { Mazes errors } \\
\text { (weight) }\end{array}$ & 0.38 & 0.32 & 0.24 & 0.21 & 0.18 & 0.11 & 5.443 & $.006^{*}$ & .100 & $\begin{array}{c}6-7>8-9 \\
(p=0.032) \\
6-7>10-12 \\
(p=0.002)\end{array}$ \\
\hline Planning Index Rey & 135.76 & 44.53 & 119.13 & 50.84 & 111.54 & 15.37 & 1.624 & .203 & .033 & NS \\
\hline
\end{tabular}




\section{Flexibility}

There was a significant main effect of age on KCST completion time. Post hoc analysis revealed that children aged 10-12 required significantly less time than children aged 8-9. Significant differences were also observed between group ages 6-7 and 1012.

Gender effect was non-significant and no interaction effects were observed between gender and age.

There was a significant effect of Level of Education of Mother on KCST number of perseverative errors showing better performance in children with higher maternal education. Similarly, Level of Education of Father had an effect on KCST number of perseverative errors. Children with father's level of education $<12$ showed more errors than children with father's level of education $>15$.

The other effects were non-significant.

\section{Working memory}

A main effect of age was observed on Verbal Updating Baseline, Visual Updating Baseline, and Visual Updating Performance score. Post hoc analysis revealed that scores on Verbal Updating Baseline were significantly higher in children aged 1012 when compared to children aged 6-7. On Visual Updating Baseline, children aged 6-7 scored significantly lower than children aged 8-9 and 10-12, and children aged 8-9 scored significantly less than children aged 10-12. On Visual Updating Performance, children aged 6-7 showed worse performance than children aged 8-9 and 10-12.

Gender effect was non-significant and no interactions between gender and age were observed on measures of working memory.

Concerning the influence of Level of Education of Mother on Visual Updating Performance, children with maternal level of education $>15$ showed significantly better performance than children with maternal level of education $<12$. Finally, regarding Father's level of education, a significant effect was observed on Verbal Updating baseline showing better performance in children with higher paternal level of education. There was also an effect of Level of Education of Father on Visual Updating Performance showing better performance in children with higher paternal education.

The other effects were non-significant.

\section{Planning}

There was a significant effect of age on Mazes number of completed items. Post hoc analysis showed that children aged 8-9 and 10-12 completed significantly more items than children aged 6-7. There was also a significant effect of age on Mazes completion time with post hoc analysis showing a significant reduction of time required to complete the task between ages 8-9 and 10-12 and 6-7 and 10-12. Similarly, a significant effect of age was observed on number of errors on Mazes task. Post hoc analysis showed that children aged 6-7 made significantly more errors than children aged 8-9 and children aged 10-12.

Regarding the influence of gender, there was a main effect of gender on Mazes completion time showing girls were slower than boys to complete that task. We

Roukoz Cynthia | Développement des Fonctions Exécutives chez les Enfants 
observed no interactions between age and gender.

Concerning mother's level of education, there was a significant effect of number of completed Mazes and number of errors showing better performance in children with higher maternal education on both measures. Finally, there was an effect of father's level of education on Mazes completion time showing that children with higher paternal education were slower than children with lower paternal education. The other effects were non-significant.

Table 3. Descriptive Data for Executive Indices by gender and gender effects

\begin{tabular}{|c|c|c|c|c|c|c|c|}
\hline & \multicolumn{2}{|c|}{ Girls (N=54) } & \multicolumn{3}{|c|}{ Boys ( $N=46$ ) } & \multicolumn{2}{|c|}{ Analysis } \\
\hline & Mean & SD & Mean & SD & $\mathrm{F}$ & $\mathrm{p}$ & $\eta 2$ \\
\hline \multicolumn{8}{|l|}{ Inhibition } \\
\hline Stroop time & 81.20 & 38.25 & 71.74 & 56.77 & 1.065 & .305 & .011 \\
\hline Stroop errors & 3.48 & 3.97 & 4.00 & 5.43 & .004 & .953 & $>.001$ \\
\hline Tapping Go No Go time & 4.26 & 8.84 & 9.41 & 15.16 & 5.415 & $.022 *$ & .054 \\
\hline Tapping Go No Go errors & 0.57 & 0.76 & 0.85 & 1.02 & 2.005 & .160 & .021 \\
\hline Tapping conflicting time & 24.74 & 10.48 & 27.54 & 19.40 & .008 & .930 & $>.001$ \\
\hline Tapping conflicting errors & 1.80 & 1.65 & 1.48 & 1.51 & .740 & .392 & .008 \\
\hline \multicolumn{8}{|l|}{ Flexibility } \\
\hline Trail Making Test Flexibility Index & 33.96 & 61.47 & 36.05 & 51.25 & 1.093 & .298 & .011 \\
\hline KCST Time & 295.32 & 95.52 & 316.12 & 88.35 & .140 & .709 & .002 \\
\hline KCST Perseverations & 2.56 & 2.91 & 3.57 & 4.78 & .603 & .440 & .007 \\
\hline \multicolumn{8}{|l|}{ Working memory } \\
\hline Verbal updating baseline & 25.52 & 3.93 & 24.96 & 4.82 & .241 & .625 & .003 \\
\hline Verbal updating performance index & 42.09 & 12.90 & 45.05 & 9.88 & .380 & .539 & .004 \\
\hline Visual updating baseline & 25.85 & 3.26 & 25.30 & 3.43 & .251 & .617 & .003 \\
\hline Visual updating performance index & 26.11 & 10.81 & 25.82 & 9.61 & .029 & .864 & $<.001$ \\
\hline \multicolumn{8}{|l|}{ Planning } \\
\hline Mazes completed items & 7.61 & 0.99 & 7.74 & 0.87 & .935 & .336 & .010 \\
\hline Mazes completion time & 117.78 & 50.81 & 99.44 & 40.65 & 4.517 & $.036^{*}$ & .051 \\
\hline Mazes errors (weight) & 0.22 & 0.16 & 0.27 & 0.27 & $<0.001$ & .985 & $<.001$ \\
\hline Planning Index Rey & 119.84 & 29.34 & 119.65 & 48.53 & .868 & .354 & .009 \\
\hline
\end{tabular}

*significant results

Table 4. Descriptive Data for Executive Indices by level of education of parents

\begin{tabular}{|c|c|c|c|c|c|c|c|c|c|c|c|c|}
\hline & \multicolumn{4}{|c|}{ mother's level of education } & \multicolumn{2}{|c|}{ Analysis } & \multicolumn{4}{|c|}{ father's level of education } & \multicolumn{2}{|c|}{ Analysis } \\
\hline & \multicolumn{2}{|c|}{$<12(n=31)$} & \multicolumn{2}{|c|}{$>15(n=69)$} & \multirow[b]{2}{*}{$\mathrm{F}$} & \multirow[b]{2}{*}{$\mathrm{p}$} & \multicolumn{2}{|c|}{$<12(n=42)$} & \multicolumn{2}{|c|}{$>15(n=58)$} & \multirow[b]{2}{*}{$\mathrm{F}$} & \multirow[b]{2}{*}{$\mathrm{p}$} \\
\hline & mean & sd & mean & sd & & & mean & sd & Mean & sd & & \\
\hline Years of education & 10.42 & 1.89 & 15.51 & 1.12 & & & 10.07 & 2.41 & 16.29 & 1.83 & & \\
\hline \multicolumn{13}{|l|}{ Inhibition } \\
\hline Stroop time & 75.94 & 46.74 & 77.26 & 49.10 & $<0.001$ & 0.915 & 78.45 & 45.49 & 75.69 & 50.34 & 0.850 & 0.521 \\
\hline Stroop errors & 4.26 & 4.11 & 3.48 & 4.99 & 0.864 & 0.203 & 3.31 & 4.53 & 4.02 & 4.88 & 0.290 & 0.637 \\
\hline Tapping GNG time & 4.81 & 5.68 & 7.45 & 14.52 & 18.419 & 0.729 & 8.43 & 15.10 & 5.33 & 10.14 & 3.785 & 0.136 \\
\hline Tapping GNG errors & 0.58 & 0.85 & 0.75 & 0.93 & 0.199 & 0.933 & 0.62 & 0.94 & 0.76 & 0.88 & 0.107 & 0.484 \\
\hline
\end{tabular}




\begin{tabular}{|c|c|c|c|c|c|c|c|c|c|c|c|c|}
\hline Tapping conflicting time & 24.48 & 12.75 & 26.72 & 16.47 & 3.759 & 0.824 & 27.69 & 18.00 & 24.83 & 13.21 & 0.006 & 0.411 \\
\hline Tapping Conflicting errors & 2.23 & 1.69 & 1.39 & 1.51 & 0.160 & $0.015^{*}$ & 1.79 & 1.70 & 1.55 & 1.54 & 0.872 & 0.462 \\
\hline \multicolumn{13}{|l|}{ Flexibility } \\
\hline TMT flexibility index & 35.73 & 52.96 & 34.57 & 59.51 & 0.211 & 0.744 & 29.11 & 62.99 & 39.14 & 52.96 & 0.020 & 0.422 \\
\hline KCST time & 289.73 & 80.42 & 312.11 & 98.86 & 0.108 & 0.380 & 288.78 & 82.07 & 315.60 & 99.59 & 0.616 & 0.152 \\
\hline KCST perseverative errors & 4.03 & 3.02 & 2.53 & 4.24 & 0.854 & $0.006 *$ & 3.92 & 2.86 & 2.42 & 4.43 & 0.482 & $0.02 *$ \\
\hline \multicolumn{13}{|l|}{ Working memory } \\
\hline verbal updating baseline & 24.77 & 4.40 & 25.48 & 4.40 & 0.261 & 0.279 & 24.10 & 4.16 & 26.10 & 4.40 & 0.369 & $0.019 *$ \\
\hline $\begin{array}{l}\text { verbal updating } \\
\text { performance }\end{array}$ & 40.00 & 10.72 & 44.82 & 12.10 & 2.021 & 0.074 & 40.08 & 11.80 & 45.64 & 11.45 & 0.281 & $0.014^{*}$ \\
\hline visual updating baseline & 26.10 & 2.87 & 25.38 & 3.57 & 1.114 & 0.268 & 25.95 & 3.08 & 25.34 & 3.57 & 1.668 & 0.384 \\
\hline $\begin{array}{l}\text { visual updating } \\
\text { performance } \\
\text { Planning }\end{array}$ & 22.03 & 9.57 & 27.78 & 10.24 & 1.217 & $0.025^{*}$ & 24.40 & 10.80 & 27.14 & 9.91 & 0.006 & 0.212 \\
\hline Mazes completed items & 7.71 & 0.86 & 7.65 & 0.98 & 26.397 & $0.003^{*}$ & 7.50 & 1.31 & 7.79 & 0.52 & 2.745 & 0.477 \\
\hline Mazes completion time & 110.99 & 42.17 & 108.33 & 50.00 & 1.608 & 0.555 & 104.56 & 55.65 & 112.49 & 40.77 & 0.245 & $0.004^{*}$ \\
\hline Mazes errors & 0.20 & 0.20 & 0.27 & 0.23 & 2.457 & $0.017^{*}$ & 0.26 & 0.28 & 0.24 & 0.16 & 0.989 & 0.411 \\
\hline Rey planning index & 119.47 & 29.81 & 119.88 & 43.41 & 0.138 & 0.138 & 115.21 & 22.71 & 123.04 & 48.15 & 0.068 & 0.790 \\
\hline
\end{tabular}

*significant results

\section{DISCUSSION}

The main aim of the current study was to adapt, to the Arabic language and the Lebanese context, tools of EF in children, and use them to examine the development of four EF domains (inhibition, working memory, planning, and flexibility) in Lebanese children and investigate their interactions with gender, level of education of mother and level of education of father.

We had hypothesized, on the basis of previous studies (Bellaj el al. 2015; Lehto et al., 2003; Sheppard \& Cheatham, 2017), a significant effect of age showing progression of EF components between ages 6 and 12 in Lebanese children, a significant effect of level of education of parents on EF performance of Lebanese children (Ardila el al. 2005; Last et al., 2018), and a non-significant effect of gender (Arán-Filippetti \& Allegri, 2011; Armengol, 2002; Brocki \& Bohlin, 2004; Welsh et al., 1991).

Regarding the effect of age on EF measures, overall, as expected based on Diamond's model (Diamond, 2013), we observed developmental changes on most tasks of EF between the ages of 6 and 12 and the improvement of Lebanese children on tasks of EF was not homogenous across age groups.

For inhibition, we found a gradual improvement of performance between ages 6 and 12 for both, time required to complete the Tapping test as well as number of conflicting errors committed. Those findings suggest a gradual improvement of inhibition of a motor response. The most striking developmental improvements were found between ages 6-7 and 8-9 with no significant improvement in the older age group, suggesting a peak of development on that task in early school-aged children. Similar findings were observed by others using comparable motor inhibition tasks (Brocki \& Bohlin, 2004; Klenberg et al., 2001). On the other hand, we did not observe the 
expected improvement on the Stroop test as reported in previous studies (Bellaj et al., 2015; Lehto \& Uusitalo, 2006; Sabbagh et al., 2006). On a Tunisian sample, Bellaj et al. (2015) observed that the interference score steadily improved with age (between 7 and 12 years old) however, when using the same Arabic adaptation on Lebanese children, the interference score was lower for the younger children, which suggests a false presumption that younger children show better inhibition than older children. This finding may be explained by the observed difficulties and lack of automaticity in young Lebanese children when naming and reading colors in Arabic. Indeed, the Stroop effect may be confounded by poor reading skills and may not properly assess inhibitory control in children who are not fluent readers in the language of assessment (MacLeod, 1991). Lebanese children, as described above, often show poor literacy skills in Arabic due to their particular school system advantaging literacy skills in the child's main language of instruction, being either French or English.

Regarding the development of flexibility, by using the KCST, which is a childhood adaptation of the WCST, we observed no significant changes with age on the number of perseverative errors yet we observed a gradual decrease of completion time between ages 8 and 12. Controversially, Davidson et al. (2006) observed an increase of time needed to complete a similar shifting task with an improvement of performance from ages four to adolescence. They attributed this «speed-accuracy trade-off» to the children's tendency, as they age, to slower their response rate in order to make sure they were responding accurately. Others such as Huizinga et al. (2006) similarly observed a decrease of completion time between ages 11 and 15 on a computerized version of WCST. While some developmental changes were observed using the KCST, we observed no significant improvement on the Trail Making Test, which contradicts findings of others (Lee et al., 2014). We may expect, based on various studies showing prolonged development of flexibility, a later improvement, after the age of 12, on tasks of flexibility among Lebanese children (Garon et al., 2008; Huizinga et al., 2006).

Concerning working memory, it seemed to improve steadily between the ages 6 and 12. On some working memory measures (visual updating baseline, visual updating performance index), we observed a peak in children's performance between ages 6 and 9 and a stabilization of performance after 9 while, on other measures (verbal updating baseline), Lebanese school-aged children showed a gradual and steady improvement between ages 6 and 12. Our findings therefore mirror what was described in the literature: a continuous and prolonged development of working memory until adolescence (Best et al., 2009; Gathercole, et al., 2004; Luciana et al., 2005).

Finally, planning also seemed to show the same progression throughout school-age as shown by steady improvement on tasks of Mazes between age groups 6-7, 8-9, and 10-12. Similar developmental trends on mazes tasks were observed by other studies (Sheppard \& Cheatham, 2017) showing a continuous decrease of errors between ages 7 and 12. On the other hand, the planning index of the Rey Complex Figure Test did not show significant changes with age which contradicts findings of others (Akshoomoff \& Stiles, 1995; Anderson et al., 2001; Martens et al., 2014). For instance, Anderson et al. (2001) showed considerable age-related variation in strategy formation occurring between the ages of 7 and 11 while the same was not observed among 
Lebanese children.

The second objective of the present study was to analyze the effects of gender and level of education of parents on Lebanese children's EF development. We found a main effect of gender on one measure of planning with boys showing better speed than girls when completing a series of Mazes. On the other hand, Lebanese girls were faster than Lebanese boys on an inhibition task (Go No Go). Based on our findings, the effect of gender on EF performance was not significant, except for two measures, and we do not have enough evidence to conclude that one gender shows better performance than the other on most tasks of EF. As observed by previous studies (Arán-Filippetti \& Allegri, 2011; Armengol, 2002; Bellaj et al., 2015), gender did not significantly influence Lebanese children's EF skills. Our findings may suggest that Lebanese families may be giving equal opportunities to boys and girls in their education allowing both genders to develop their EF skills simultaneously. Lebanon is a country that relatively recently, started fostering equality between genders, including encouraging parents to raise boys and girls equally and granting them equal life opportunities. While struggles with inequality have been prominent in Middle Eastern countries (Krafft \& Alawode, 2018) it does not seem to reflect as such in our results.

Regarding parent's education level, we found significant effects of both mother and father's education level on many EF measures. For example, on a flexibility measure, children whose maternal level of education was high school or less showed twice the number of perseverative errors when compared to children whose mothers were university graduates. Also, Lebanese children with lower mother's level of education showed worse performance on a task of visuospatial working memory (visuospatial updating test), motor inhibition task (child tapping test), flexibility (KCST) and on a planning task (8 Mazes test). Also, children with lower paternal education levels showed worse performance on tasks of flexibility (KCST), verbal working memory (verbal updating test), and planning (8 mazes test). Overall, our results suggest that children with more educated parents showed better performance on many EF tasks, mirroring findings of previous studies (Ardila et al., 2005; Bellaj et al., 2015; Last et al., 2018). In an attempt to potentially explain these influences, some authors have hypothesized that better EF in offspring may be related to heritability and genetic influences. We could hypothesize that children with higher level of parental education would inherit their higher cognitive functioning. In addition, parents with higher level of education would expose their children to cognitive stimulation and environmental conditions that would foster better cognitive development and would allow generalization of education-based recommendations (Wilson, 2018). They also suggested that the higher the level of education of a parent, the more his/her ability to "delay rewards", as parents with university degrees had to study more years than less educated parents before they were able to earn money and be compensated for their efforts. Those skills would be reflected in their parenting styles and inherited to their children. It is also important to stress on the fact that parental level of education is not an isolated variable and reflects many associated living conditions such as a family's socioeconomical status, the parent's system of values, parent's intellectual abilities, and parent's personal interest which in line play a major role in a child's EF and self-

Roukoz Cynthia | Développement des Fonctions Exécutives chez les Enfants 
regulation development (Ardila et al., 2005; Lipina \& Evers, 2017).

From a theoretical perspective, our results allow us to question the currently available theoretical models of EF development (for example, Diamond, 2013; Lee et al., 2013), which do not account for sociodemographic influences to explain the developmental trajectories of EF. From a local perspective, Lebanon has witnessed a particularly devestating year 2020 with socio-economic and political disturbances, and it is currently estimated that $55 \%$ of Lebanese families live under the threshold of poverty (http://www.unescwa.org/). Since level of education of parents is often an indicator of socio-economic status (Aarø et al., 2009), based on our findings, we may expect an impact of the current socio-economic crisis on the cognitive development of Lebanese children.

Despite being the first study to present such developmental data on EF development across Lebanese children, many limits should be considered. First, our limited sample size, which led to some subgroups showing large variations of scores across the sample, may have biased some of our findings. Also, our sample excluded children from public schools mainly due to the high number of Syrian and Palestinians refugees attending public schools, which complicated our recruitment among public schools. Nonetheless, since $70 \%$ of Lebanese children attend private schools (Centre de Recherche et de Developpement Pédagogique, 2017), they were estimated to serve as an appropriate representation of the Lebanese children. Also, as mentioned previously, multiple languages are spoken in Lebanon and while Arabic remains the official language, French and English are Lebanese school's primary languages of instructions. Some Lebanese families will prioritize speaking to their child in a foreign language (French or English), while others will use Arabic as a primary mean of communication. Therefore, the choice of language used when assessing a Lebanese child may affect test findings. Our experience with the Arabic Stroop test illustrates well the above and suggests that the Arabic Stroop may not be an effective measure of inhibition in young Lebanese children. This example illustrates one of our major challenges when conducting neuropsychological assessments in Lebanese children. As mentioned previously, Lebanon is a country with many cultural and educational heterogeneity and the language chosen for the assessment greatly influences a child's result.

From a prospective point of view, the current study should be expanded and include a larger sample of Lebanese children as well as include children from public schools and from various geographical areas and socioeconomical status in Lebanon since those factors are known to potentially influence EF development (Ardila et al, 2005; Noble et al., 2015; Shayer et al., 2015). It is particularly important to expand the current study allowing us to have normative data for the adapted measures of EF in Lebanon 


\section{References}

Akshoomoff, N. A., \& Stiles, J. (1995). Developmental Trends in Visuospatial Analysis and Planning: I. Copying a Complex Figure. Neuropsychology, 37(2), 16-27. https://doi.org/10.1037/0894-4105.9.3.364

Anderson, P., Anderson, V., \& Garth, J. (2001). Assessment and development of organizational ability: The Rey Complex Figure Organizational Strategy Score (RCF-OSS). Clinical Neuropsychologist, 15(1), 81-94. https://doi.org/10.1076/clin.15.1.81.1905

Ardila, A., Rosselli, M., Matute, E., \& Guajardo, S. (2005). The influence of the parents' educational level on the development of executive functions.

Developmental Neuropsychology, 28(1), 539-60. https://doi.org/10.1207/s15326942dn2801_5

Armengol, C.G. (2002). Stroop test in Spanish: Children's norms. Clin Neuropsychol. 16(1), 67-80. https://doi.org/10.1076/clin.16.1.67.8337.

Bellaj, T., Salhi, I., Le Gall, D., \& Roy, A. (2016a). Development of executive functioning in school-age Tunisian children. Child Neuropsychology, 22(8), 919-954. https://doi.org/10.1080/09297049.2015.1058349

Berlin, L., \& Bohlin, G. (2002). Response Inhibition, Hyperactivity, and Conduct Problems Among Preschool Children. Journal of Clinical Child and Adolescent Psychology. https://doi.org/10.1207/S15374424JCCP3102_09

Best, J. R., Miller, P. H., \& Jones, L. L. (2009). Executive functions after age 5. Developmental Review, 29, 180-200. https://doi.org/10.1016/j.dr.2009.05.002 T4

Brickman, A.M., Cabo, R., \& Manly, J.J. (2006). Ethical issues in cross-cultural neuropsychology. Appl Neuropsychol, 13(2), 91-100. https://doi.org/10.1207/s15324826an1302_4.

Bruner, J. S. (1966). Toward a theory of instruction, Cambridge, Mass.: Belkapp Press.

Brocki, K. C., \& Bohlin, G. (2004). Executive functions in children aged 6 to 13: A dimensional and developmental study. Developmental Neuropsychology, 26(2), 571-593. https://doi.org/10.1207/s15326942dn2602_3

Boone, K. B., Victor, T. L., Wen, J., Razani, J., \& Pónton, M. (2007). The association between neuropsychological scores and ethnicity, language, and acculturation variables in a large patient population. Archives of Clinical Neuropsychology. $22(3): 355-365$.

Roukoz Cynthia | Développement des Fonctions Exécutives chez les Enfants 
Chasiotis, A., Kiessling, F., Campos, D. \& Hofer, J. (2006). Theory of mind and inhibitory control in three cultures: Conflict inhibition predicts false belief understanding in Germany, Costa Rica and Cameroon. International Journal of Behavioral Development, 30(3), 249-260. https://doi.org/10.1177/0165025406066759

Davidson, M. C., Amso, D., Anderson, L. C. \& Diamond, A. (2006). Development of cognitive control and executive functions from 4 to 13 years: Evidence from manipulations of memory, inhibition, and task switching. Neuropsychologia, 44(1), 2037-2078. https://doi.org/10.1016/j.neuropsychologia.2006.02.006

Dennis, M. (2006). Prefrontal cortex: Typical and atypical development. In J. Risberg et J. Grafman (Eds.), The frontal lobes: Development, function and. pathology (p. 128-162). New York: Cambridge University Press.

Diamond, A. (2013). Executive functions. In Annual Review of Psychology, 66, 114142. https://doi.org/10.1146/annurev-psych-113011-143750

Filippetti, V. A. (2011). Executive Functions in School-aged Children: Age and Socio-economic Status Effect. Avances En Psicologia Latinoamericana, 29(1), 98-113.

Garon, N., Bryson, S. E., \& Smith, I. M. (2008). Executive Function in Preschoolers: A Review Using an Integrative Framework. Psychological Bulletin, 134(1): 3160. https://doi.org/10.1037/0033-2909.134.1.31

Gathercole, S. E., Pickering, S. J., Ambridge, B. \& Wearing, H. (2004). The Structure of Working Memory from 4 to 15 Years of Age. Developmental Psychology, 40(2), 277-190. https://doi.org/10.1037/0012-1649.40.2.177

Halpern, D. F., \& LaMay, M. L. (2000). The Smarter Sex: A Critical Review of Sex Differences in Intelligence. Educational Psychology Review. https://doi.org/10.1023/A:1009027516424

Huizinga, M., Dolan, C. V. \& Van Der Molen, M. W. (2006). Age-related change in executive function: Developmental trends and a latent variable analysis. Neuropsychologia, 44(11), 2017-36.

Hynd, G. W. (1987). Neuropsychological Development of Nonverbal Behaviors Attributed to "Frontal Lobe" Functioning. Developmental Neuropsychology. https://doi.org/10.1080/87565648709540381

Klenberg, L., Korkman, M., \& Lahti-Nuuttila, P. (2001). Differential development of attention and executive functions in 3- to 12-year-old Finnish children. Developmental Neuropsychology. https://doi.org/10.1207/S15326942DN2001_6 
Lahat, A., Todd, R. M., Mahy, C. E. V., Lau, K. \& Zelazo, P. D. (2010). Neurophysiological correlates of executive function: A comparison of europeancanadian and chinese-canadian 5-year-old children. Frontiers in Human Neuroscience. https://doi.org/10.3389/neuro.09.072.2009

Lan, X., Legare, C. H., Ponitz, C. C., Li, S., \& Morrison, F. J. (2011). Investigating the links between the subcomponents of executive function and academic achievement: A cross-cultural analysis of Chinese and American preschoolers. Journal of Experimental Child Psychology. https://doi.org/10.1016/j.jecp.2010.11.001

Last, B. S., Lawson, G. M., Breiner, K., Steinberg, L., \& Farah, M. J. (2018). Childhood socioeconomic status and executive function in childhood and beyond. PLoS ONE, 13(8). https://doi.org/10.1371/journal.pone.0202964

Lee, K., Bull, R., \& Ho, R. M. H. (2013). Developmental changes in executive functioning. Child Development, 84(6), 1933-53. https://doi.org/10.1111/cdev.12096

Lehto, J. E., Juujärvi, P., Kooistra, L. \& Pulkkinen, L. (2003). Dimensions of executive functioning: Evidence from children. British Journal of Developmental Psychology, 21(1), 59-80. https://doi.org/10.1348/026151003321164627

Lehto, J. E., \& Uusitalo, A.-K. (2006). Rule detection in preschool-aged children. European Journal of Developmental Psychology, 3(3), 209221. https://doi.org/10.1080/17405620500412374

Lipina, S. J. \& Evers, K. (2017). Neuroscience of childhood poverty: Evidence of impacts and mechanisms as vehicles of dialog with ethics. Frontiers in Psychology, 8,61. https://doi.org/10.3389/fpsyg.2017.00061

Luciana, M., Conklin, H. M., Hooper, C. J. \& Yarger, R. S. (2005). The development of nonverbal working memory processes in adolescence: different maturational trajectories for recall versus executive control. Child Development, 76(3), 697712. https://doi.org/10.1111/j.1467-8624.2005.00872.x

Loewenstein, D.A., Arguelles, T., Arguelles, S., \& Linn-Fuentes, P. (1994). Potential cultural bias in the neuropsychological assessment of the older adult. Journal of Clinical and Experimental Neuropsychology, 16, 623-629

Luria, A. R. (1995). Higher Cortical Functions in Man. In Higher Cortical Functions in Man. https://doi.org/10.1007/978-1-4684-7741-2

Martens, R., Hurks, P. P. \& Jolles, J. (2014). Organizational strategy use in children aged 5-7: standardization and validity of the Rey Complex Figure Organizational Strategy Score (RCF-OSS). The Clinical Neuropsychologist, 28(6), 1-20. 
https://doi.org/10.1080/13854046.2014.939228

Miyake, A., Friedman, N. P., Emerson, M. J., Witzki, A. H., Howerter, A. \& Wager, T. D. (2000). The Unity and Diversity of Executive Functions and their Contributions to Complex "Frontal Lobe" Tasks: A Latent Variable Analysis. Cognitive Psychology, 41(1), 49-100. https://doi.org/10.1006/cogp.1999.0734

Noble, K. G., Houston, S. M., Brito, N. H., Bartsch, H., Kan, E., Kuperman, J. M., Akshoomoff, N., Amaral, D. G., Bloss, C. S., Libiger, O., Schork, N. J., Murray, S. S., Casey, B. J., Chang, L., Ernst, T. M., Frazier, J. A., Gruen, J. R., Kennedy, D. N., Van Zijl, P., ... Sowell, E. R. (2015). Family income, parental education and brain structure in children and adolescents. Nature Neuroscience, 18(5), 773-778. https://doi.org/10.1038/nn.3983

Peña, E. D., Bedore, L. M., \& Zlatic-Giunta, R. (2002). Category-Generation Performance of Bilingual Children. Journal of Speech, Language, and Hearing Research. https://doi.org/10.1044/1092-4388(2002/076)

Roukoz, C., Er Rafiqi, M., Le Gall, D., Bellaj, T., \& Roy, A. (2018). A Systematic Review of Cross-cultural Studies on Executive Functions in Children. International Journal of Psychology and Neuroscience, 4(3), 1-31

Sabbagh, M. A., Xu, F., Carlson, S. M., Moses, L. J. \& Lee, K. (2006). The development of executive functioning and theory of mind: A comparison of Chinese and U.S. preschoolers. Psychological Science 17(1), 74-81. https://doi.org/10.1111/j.1467-9280.2005.01667.x

Shayer, B., Carvalho, C., Mota, M., Argollo, N., Abreu, N. \& Bueno, O. F. A. (2015). Desempenho de escolares em atenção e funções executivas no Nepsy e inteligência. Revista Psicologia-Teoria e Prática, 17(1), 120-135.

Sheppard, K. W. \& Cheatham, C. L. (2017). Validating the Electric Maze Task as a Measure of Planning. Journal of Cognition and Development, 18(2), 309-322. https://doi.org/10.1080/15248372.2016.1195387

Tabar, P. (2009). Immigration and Human Development: Evidence from Lebanon. Tabar Paul 2009 Immigration and Human Development Evidence from Lebanon Published in Human Development Research Paper HDRP Series Vol 35 No 2009.

Welsh, M., Pennington, B., \& Groisser, D. (1991) A normative-developmental study of executive function: A window on prefrontal function in children, Developmental Neuropsychology, 7(2), 131149, doi: $\underline{10.1080 / 87565649109540483}$ 
Yaacoub, N., \& Badre, L. (2012). Education in Lebanon. Central Administration of Statistics.

Roukoz Cynthia | Développement des Fonctions Exécutives chez les Enfants 


\section{ETUde 2 : CAS CLINIQUe : FonCTIONS \\ EXECUTIVES CHEZ UN ENFANT LIBANAIS}

AVEC UNE EPILEPSIE DU LOBE FRONTAL

Ce chapitre présente le manuscrit suivant:

Roukoz, C., Le Gall, D. \& Roy, A. A Neuropsychological Clinical Case Study of Executive Function in a Child with Frontal Lobe Epilepsy. Manuscript under review.

Soumis le 01 Octobre 2020 à la revue Epilepsy \& Behavior Case Reports. 
A Neuropsychological Clinical Case Study of Executive Function in a Child with Frontal Lobe Epilepsy

\author{
Cynthia Roukoz, MA a ; Didier Le Gall, $\mathrm{PhD}^{\mathrm{b}}$; Arnaud Roy, $\mathrm{PhD}^{\mathrm{b}}$ \\ aDepartment of Psychiatry, American University of Beirut Medical Center; \\ bLaboratoire de Psychologie des Pays de la Loire.
}

\title{
Corresponding author:
}

Cynthia Roukoz

Department of Psychiatry, American University of Beirut Medical Center Cairo Street, Hamra, Beirut, Lebanon

cr21@aub.edu.lb 


\title{
A Neuropsychological Clinical Case Study of Executive Function in a Child with \\ Frontal Lobe Epilepsy
}

Cynthia Roukoz, MA; Didier Le Gall, PhD; Arnaud Roy, PhD

\begin{abstract}
The cognitive profile of children with Frontal Lobe Epilepsy (FLE) shows main problems with EF. However, no neuropsychological studies have been conducted on Middle Easter Children evaluating the impact of FLE on their development and whether their profile is similar to what is typically described in the literature. The current study presents the case of an 8-year old Lebanese boy who underwent a right frontal craniotomy in the context of right frontal cortical dysplasia with refractory epilepsy, 12 months prior to the assessment. A comprehensive neuropsychological assessment was conducted. Among the tools used, Arabic adaptations of the CEF-B and the BRIEF were administered to the young boy to assess Executive Functions (EF). The CEF-B is an experimental battery of test of EF in children. Results: The young boy showed results suggesting borderline intellectual functioning along with a Language Disorder and major impairments in most EF skills. He showed EF impairments as assessed through performance-based measures (CEF-B) and through a scale completed by his parents (BRIEF - Parent form). He also showed Attention Deficit/Hyperactivity Disorder symptoms on the Vanderbilt ADHD rating scale.

Keywords: Frontal Lobe Epilepsy; Executive Functions; Attention Deficit/Hyperactivity Disorder; Language Disorder; Assessment.
\end{abstract}




\section{INTRODUCTION}

Frontal Lobe Epilepsy (FLE) is characterized by recurrent seizures arising from the frontal lobes and is the second most common type of focal epilepsies in children [1]. FLE has a significant impact on a child's behavioral and cognitive development [24]. Specifically, the development of Executive Functions (EF) is often compromised in FLE, leading to wide set of difficulties in children $[2,5,6]$.

EF is defined as a collection of top-down control processes used when an automatic or instinctive response is not sufficient to appropriately complete an ongoing task [7]. EF development is known to be influenced by cultural and sociodemographic context and it is therefore difficult to generalize western studies on EF development to other cultures [8-11]. EF is also correlated to a person's mental and physical health, educational and occupational attainment, and overall quality of life [7], making it a major area of concern in developing children with neurological disorders.

Assessing the neuropsychological functioning of children is an important step in the context of epilepsy $[12,13]$. Furthermore, EF impairments, being often associated with epilepsy [14], should be consistently evaluated. EF is typically assessed using performance-based tests targeting its various aspects as well as questionnaires assessing behavioral symptoms impacting the child's functioning in his daily life [15]. Unfortunately, tools of EF in children are lacking in many developing countries, and there are, to date, no tools adapted to the Lebanese population permitting the assessment of EF among Lebanese children. The lack of tools is currently being compensated for by using tests and norms intended for American or French children which poses a wide range of problems and questions the validity of the evaluation conducted [16,17]. Recently, the Arabic adaptation of the CEF-B, which is an 
assessment battery of EF in children, was conducted (Roukoz et al. 2020, under review). The CEF-B is a battery of tests of EF that was initially created in France and which is based on Diamond's model of EF [7]. It comprises tools evaluating the 4 main components of EF: Inhibition, Working Memory, Flexibility, and Planning. Tests included in the CEF-B assess the various components of EF through verbal and visual modalities. Eight of the 12 tests as well as the Behavior Rating Inventory of Executive Functions (Parent form) (BRIEF), which assesses, through a questionnaire completed by parents, problematic behaviors related to EF dysfunctions in daily life, were adapted to the Lebanese context using a translation/back-translation procedure as recommended by experts in test adaptations [18]. The protocol was administered to 100 healthy Lebanese children aged from 6 to 12 to observe the normal EF developmental trend in Lebanese children. This step served as a preliminary validation study of the CEF-B on Lebanese children (Roukoz et al., 2020, manuscript under review). Results revealed a main developmental effect of age on measures of inhibition, working memory and planning and to a lesser extent, flexibility, showing preliminary evidence of the validity of the tool. The effect of gender was nonsignificant whereas the effect of mother and father's level of education were significant for most measures, as expected based on the literature $[16,19]$.

Assessing EF in children with FLE is necessary since children with FLE show main problems in that area such as difficulties with planning abilities, working memory, impulse control, flexibility, switching, inhibition and attention $[5,20]$ as well as behavioral disturbances [2,21]. For instance, [22] compared groups with righttemporal, left-temporal, and frontal epilepsies and their study yielded significant differences between the left-temporal and frontal groups on the Wisconsin CardSorting Test (WCST) number of categories, with the frontal group demonstrating the 
greatest deficits. Also, although mean differences were not significant, the frequency of impaired performance by the frontal group on the Children Memory Scale Attention/Concentration Index was greater than that of the temporal groups. Furthermore, [23] used two measures of cognitive control, the Stroop test and the WCST, to assess EF in children with FLE, and showed that $20 \%$ of the children displayed significant low results on the Stroop Effect and $60 \%$ showed shifting problems on the WCST. Similarly, using different tools such as Digits Backward (WISC-IV), Trail Making Test, Stroop Test, Design Fluency subtest of the NEPSY and three tests from the Cambridge Neuropsychological Testing Automated Battery (CANTAB), [24] showed that children with FLE performed significantly lower that healthy controls on tasks of verbal working memory, mental flexibility, and design fluency and they were more sensitive to cognitive interference. On the other hand, they found no significative differences between children with FLE and healthy controls on tasks of spatial working memory, planning, set shifting and verbal fluency.

FLE has also been linked to behavioral impairments due to executive dysfunctions. For instance, [21] used the BRIEF questionnaire, both parental and teacher's ratings, to assess children with TLE and others with FLE on domains of EF. Results indicated executive dysfunctions in both group of patients as reported by parents and teachers, yet patients with FLE showed more severe symptoms related to a child's capacity to monitor his responses, self-correct his mistakes and ensure attainment to a preset goal. Furthermore, in a recent study assessing children's behavioral dysfunctions related to EF impairments through a newer version of the same questionnaire (BRIEF-2 ${ }^{\mathrm{ND}}$ edition), [25] showed significant differences between children with FLE and healthy 
controls on Task Monitor, Plan/Organize, Working Memory, and Shift scales and reported that younger age of epilepsy onset, chronic epilepsy, and right hemisphere seizure focus were associated with higher parent-reported EF concerns. Those risk factors were also reported by others stating that the severity of executive deficits, both cognitive and behavioral, were associated to the number of antiepileptic drugs, the age of onset, and the duration of the epilepsy, yet frequency of seizures did not correlate with executive impairments [4,21].

Despite the evidence showing major EF impairments in children with FLE, no study has been conducted to date describing the neuropsychological disturbances of Lebanese children with FLE. Lebanon is a country with an unfortunate history of wars and political and economic instabilities and the country recently went through a particularly disastrous year in 2020. The need for all types of psychological services in Lebanon has drastically increased this year and the country lacks appropriate tools and resources permitting proper establishment of such services. Also, since some differences in the development of EF in typically developed children have been described in the literature [11], we could presume differences in clinical samples as well. Besides, studies on the neuropsychological profile of children with FLE currently available in the literature are heterogeneous, with too many different sampling and methodological characteristics [4]. It is therefore difficult, at this point, to describe a unique profile or generalized clinical sample characterization of children with FLE. Generalizing findings issued from international studies to come up with evidence-based treatment plans to help Lebanese children with FLE could therefore be biased. 
Within that context, through a comprehensive clinical case study, we are aiming at better understanding the clinical semiology of dysexecutive syndromes in children with FLE and examine whether Lebanese children with FLE show a pattern of EF cognitive and behavioral dysfunctions as described in Western children with FLE $[4,5,24]$. In this study, the assessment of EF focused on specific EF domains based on the developmental model of Diamond [7] (inhibition, working memory, flexibility, and planning abilities) as well as a questionnaire assessing behavioral symptoms impacting the child's functioning in his daily life (BRIEF) as recommended in the literature $[15,26]$. The second objective of the present case study was to evaluate, through a preliminary single case study, the sensitivity of the CEF-B adapted to the Lebanese children, on a Lebanese child with FLE.

\section{MATERIAL AND METHODS}

\subsection{Participant:}

The patient's name was modified to respect his confidentiality.

Anthony is a right-handed Lebanese male who was referred for a neuropsychological assessment in a private outpatient clinic in Lebanon in 2018, 12 months following a right frontal craniotomy in the context of right frontal cortical dysplasia with refractory epilepsy. He was 8 years 4 months at the time of his evaluation. He presented with academic and behavioral difficulties. The young boy was fluent in Arabic and French with French being his preferred language and language of instruction at school. He lived in Mount Lebanon with his parents and two older siblings. His parents were both university Graduates. He attended a private school in Beirut and was enrolled in Grade 1. He benefitted from the presence of a full-time shadow teacher. The young boy was referred by his parents for a neuropsychological 
evaluation in order to clarify his current level of neurocognitive functioning and provide relevant recommendations for intervention.

\section{History of present concerns:}

Anthony's pre-natal, birth, and post-natal history was unremarkable as per his parents. He started having focal seizures at the age of 9 months. He was treated with several anti-epileptic drugs across the years, but his seizures were resistant to pharmacological treatments and he was having several weekly seizures.

Regarding his developmental history, Anthony was late to acquire language milestones. He started saying words after the age of 2 and construct 2-word sentences at the age of 4. Anthony's parents also reported he could not follow lengthy instructions. At the age of 4, Anthony started losing acquired language skills and had become less fluent. He was then using nonverbal gestures to express his needs or, at times, poorly structured 2-word sentences. On the other hand, gross motor skills were typically developed, and Anthony's parents reported no changes in his ability to walk, run, climb up and down the stairs, and engage in different physical activities. Nonetheless, he showed difficulties in the early development of his fine motor skills. Indeed, Anthony had difficulties holding his pencil appropriately, he was a clumsy eater, he required support when wearing his clothes and fastening his buttons, and required assistance in most activities needing precise movements. Socially, at the age of three, Anthony was withdrawn and did not initiate contact with others. Behaviorally, he was emotionally dysregulated and would throw tantrums when frustrated (i.e., he would break things and be extremely aggressive when frustrated). 
He was also hyperactive, impulsive, and violent and showed minimal empathy when his behaviors would cause pain to others.

At the age of 7, in March/2017, he underwent a right frontal craniotomy after which he was seizure-free. He was maintained on VIMPAT (brand name of lacosamid) after his surgery. Since his surgery, he steadily improved his expressive and receptive language skills but was still below what was expected at his age. Speech was poor with atypical articulation of most sounds. Academically, Anthony showed major difficulties acquiring academic skills appropriate for his age. For instance, when peers were able to read regular words and complete single-digit additions, he was able to identify 2-letter sounds and numbers from 1 to 10 . Behaviorally, since his surgery, he had become calmer, less hyperactive and distractible, less impulsive and aggressive, and was controlling his emotions better. Nonetheless, he continued to show some aggressive behaviors such as pinching or biting others when frustrated. He also continued to show poor understanding of other's point of view and showed little empathy and compassion towards other's pain.

\section{Current concerns (12 months post-surgery):}

While Anthony's behavior, emotional regulation, language and learning abilities have improved since his surgery, he continued to show impairments in those areas as reported by his parents on the day of his assessment.

Regarding his behaviors, Anthony's parents reported that he is overactive and moves around when he is supposed to remain seated, is defiant with authority, and is oppositional and stubborn. Parents also reported that he often daydreams (beyond staring spells associated with seizures), has poor organizational skills, gets easily distracted, does not go through tasks, requires constant redirections, does not pay 
attention to written and oral information, makes many inattentive mistakes, often loses his personal items, and is forgetful.

Regarding emotional problems, parents reported Anthony shows major difficulties controlling his emotions whether he is sad, irritated, or happy. He throws temper tantrums when his wishes are not met and can be physically aggressive towards parents, siblings, and peers, when irritated.

Socially, the young boy is reported to have difficulties making friends and maintaining friendships. He engages in group activities and games with peers yet gets irritated when peers do not abide by his rules when playing. He also shows difficulties following rules of games (i.e., football).

Concerning his language and expressive skills, parents reported the young boy shows difficulties finding his words and expressing himself. He is brief in his verbal responses and often needs repetitions and clarifications of lengthy instructions in order to follow them.

Anthony also shows major academic difficulties. He is currently enrolled in Grade 1 for the second consecutive year (he repeated Grade 1 last year due to multiple absenteeism and failing to meet the academic requirements allowing him to pass in Grade 2). At the time of the neuropsychological assessment, he benefitted from the full-time presence of a shadow teacher throughout the day. On reading skills, Anthony was able to recognize single letters and read familiar regular words. On the other hand, he showed difficulties acquiring writing skills. He wrote single letters with a large handwriting and had difficulties writing on a line. He also showed difficulties spelling familiar words. Calculation skills were also reported to be an area of weakness. While Anthony was able to count from 1 to 20, he was not able to perform one-digit additions. Anthony's shadow teacher implemented some accommodations 
such as providing additional time during tests, providing instructions and worksheets in large prints, and offering support throughout the day such as redirecting him to tasks, re-explaining materials, reading instructions aloud, etc.

Adaptively, Anthony relies on his parents for many daily skills and is not as independent in his daily life as other children of his age.

In view of the above concerns, Anthony has been engaged in speech/language therapy and psychomotor therapy since the age of 3 , at the rate of twice per week.

\subsection{Materials}

Parents underwent a 1-hour interview to gather relevant information regarding the child. That information was supplemented by detailed observations of behavior and performance on a variety of tests, which included in part or full, the following tests: Wechsler Intelligence Scale for Children, Fifth Edition (WISC-V); Expressive OneWord Picture Vocabulary Test, Fourth Edition (EOWPVT-4); NEPSY-II; BeeryBuktenica Developmental Test of Visual-Motor Integration, Sixth Edition (BeeryVMI-6); Grooved Pegboard (Grooved); Test of Everyday Attention for Children; Wechsler Individual Achievement Test, Second Edition (WIAT-II). Current testing was administered in French as it was the first language of Anthony yet specific changes in standardized methods were made at times. For example, some French instructions were sometimes coupled with Arabic instructions to improve comprehension of some commands.

As an addition to a comprehensive neuropsychological assessment, the Child Executive Functions Battery (CEF-B) was administered. The CEF-B is an experimental battery of tests of EF assessing the main executive processes: inhibition, flexibility, working memory and planning [7]. The CEF-B consists of a set of 12 tests 
for the neuropsychological evaluation of EF aimed at French children and adolescents between 6 and 16 years old. Eight of the twelve tests of the CEF-B were adapted to the Arabic language and to the Lebanese population. Each two tests preferentially assess one of the four EF components: inhibition, working memory, flexibility, and planning. Standardized instructions were given to the child in the Lebanese dialect, on the basis of the instructions in Modern Standard Arabic resulting from the adaptation of the tool to the Arabic language. BRIEF (parent form) was also administered to assess parental observations of behaviors associated with EF impairments in the child's home environment. Anthony's parents also completed the Vanderbilt ADHD Diagnostic Rating Scale to assess parental rating of symptoms of inattention and hyperactivity/impulsivity impacting his daily functioning.

Table 1 shows the list of tests administered as well as a brief description of each test.

Table 1: tests administered by function

\begin{tabular}{|c|c|c|c|}
\hline Domain & Test & Description & Variable \\
\hline $\begin{array}{l}\text { Intellectual } \\
\text { abilities }\end{array}$ & $\begin{array}{l}\text { Weschler Intelligence Scale for } \\
\text { Children, } 5^{\text {th }} \text { edition (WISC-V) }\end{array}$ & & \\
\hline & VCI & $\begin{array}{l}\text { Subtests of the VCI assess } \\
\text { vocabulary knowledge and verbal } \\
\text { reasoning skills. }\end{array}$ & $\begin{array}{l}\text { Index scores and scaled scores for } \\
\text { subtests. }\end{array}$ \\
\hline & VSI & $\begin{array}{l}\text { Subtests of the VSI assess visual } \\
\text { spatial analysis and visual spatial } \\
\text { construction skills. }\end{array}$ & Same \\
\hline & FRI & $\begin{array}{l}\text { Subtest of the FRI assess fluid } \\
\text { reasoning. }\end{array}$ & Same \\
\hline & WMI & $\begin{array}{l}\text { Subtest of the WMI assess visual } \\
\text { and auditory working memory. }\end{array}$ & Same \\
\hline & PSI & $\begin{array}{l}\text { Subtests of the PSI assess } \\
\text { components of attention, speed of } \\
\text { processing, and graphomotor } \\
\text { speed. }\end{array}$ & Same \\
\hline Attention & $\begin{array}{l}\text { Test of Everyday Attention in } \\
\text { Children (Tea-ch) }\end{array}$ & & \\
\hline & "Score!" subtest & $\begin{array}{l}\text { Child is required to count the } \\
\text { sounds on the recording presented } \\
\text { to him. The 'Score!' subtest } \\
\text { assesses auditory sustained } \\
\text { attention. }\end{array}$ & $\begin{array}{l}\text { Number of correct items converted } \\
\text { to percentiles }\end{array}$ \\
\hline & Sky Search & $\begin{array}{l}\text { Child is required to cancel specific } \\
\text { items from an A3 stimulus. Sky }\end{array}$ & $\begin{array}{l}\text { Number of correct items converted } \\
\text { to percentiles }\end{array}$ \\
\hline
\end{tabular}


search subtest assesses visual

selective attention.

\begin{tabular}{ll}
\hline $\begin{array}{l}\text { Visuomotor } \\
\text { integration }\end{array}$ & $\begin{array}{l}\text { Beery-Buktenica } \\
\text { Test of Visual-Motor Integration, } \\
\text { Sixth Edition }\end{array}$ \\
\hline
\end{tabular}

Beery VMI

Visual Perception

Motor Coordination

Language NEPSY-II
Comprehension of Instructions

Word generation Semantic Total

\begin{tabular}{l} 
Comprehension of Instructions \\
Word generation Semantic Total \\
\hline $\begin{array}{l}\text { Expressive One-Word Picture } \\
\text { Vocabulary Test, Fourth Edition } \\
\text { (EOWPVT-4) }\end{array}$ \\
\hline
\end{tabular}

Child is required to copy figures of increasing complexity, evaluating his visuomotor skills.

Child is required to match pictures and this subtest assesses nonmotor visual perception.

Child is required to retrace inside shapes, assessing his motor coordination and precision.
Number of correct items converted to Index score

Number of correct items converted to Index score

Number of correct items converted to Index score
Child is required to follow instructions of increasing complexity and lenght, assessing his verbal comprehension.

Child is required to recall words from a given category, assessing his verbal fluency and word retrieval.

Child is required to name pictures, Number of correct items converted assessing his vocabulary knowledge, word-retrieval, and naming abilities.

Child is required to insert small pegs inside holes using his right then his left hand, assessing his fine motor skills bilaterally.

\section{Scaled score for subtests}

Scaled score for subtests

Z-score of time required to complete all rows with the dominant and non-dominant hand. to Index score

\section{Academic Wechsler Individual Achievement achievement Test - Third Edition (WIAT-III)}

Word Reading

Child is required to read out loud letters and words.

Spelling

Child is required to spell sounds and words.

Child is required to continue Numerical Operations number sequences, count items, and complete operations of increasing complexity.

\begin{tabular}{ll}
\hline $\begin{array}{l}\text { Behavioral } \\
\text { scales }\end{array}$ & $\begin{array}{l}\text { Vanderbilt ADHD Diagnostic rating } \\
\text { scale (Parents) }\end{array}$
\end{tabular}

Parents are required to rate inattention,

hyperactivity/impulsivity, and oppositional symptoms as "never", "occasionally", “often", "very often"

Behavior Rating Inventory of Executive Function (BRIEF)

Parents are required to rate various behaviors pertaining to different aspects of EF. Each behavior is rated as occurring "never", "sometimes" and "often".
Grade and age-equivalence

Grade and age-equivalence

Grade and age-equivalence

Number of symptoms rated as "often" and "very often" in each category

Z-scores and percentiles for each clinical scale and Indexes. 


\begin{tabular}{ll}
\hline EF & CEF-B \\
\hline Inhibition & Stroop te
\end{tabular}

Child Tapping test
An Arabic adaptation of the Stroop Test was conducted. Child is expected to inhibit automatic verbal responses.

Child is expected to inhibit automatic motor responses.
*Completion time of condition $\mathrm{C}-$ Completion time A

*Numbers of errors C - Number of errors A.

*Completion time condition $\mathrm{B}$ Completion time condition A

*Total numbers of errors in condition B

*Completion time condition $\mathrm{C}$ Completion time condition A

*Total number of errors in conditions $\mathrm{B}$ and $\mathrm{C}$.

Working Visuospatial Updating test
memory

Child is expected to recall last 2 or 3 locations from a sequence.

*Total number of recalled locations on the baseline items

*The performance score which is calculated using the following formula: score on items $\mathrm{R} 0+$ score on items R2 + score on items R3. The lower the score the worse the working memory.

Verbal Updating test

Child is expected to recall last 2 or Same 3 letters from a sequence.

Flexibility Trail Making Test (TMT)

Planning 8 Mazes Test
Child is required to alternate between numbers and letters in sequence.

Kids Card Sorting Test (KCST)

The KCST is an adaptation of the WCST. Child is expected to switch from one category to another when categorizing cards.

The test comprises eight mazes of increasing difficulty which the child is expected to complete.

This test assesses the child's capacity to plan and organize the drawing of a complex figure.

*Flexibility index: completion time part B - (completion time condition A numbers + completion time condition A letters)/2)

*KCST completion time (in seconds)

*Number of perseverative errors

*Number of successfully completed Mazes (the higher the score the better the planning performance) *Completion time mean of the 8 mazes (the higher the scores the more the planning difficulties)

* Mean of number of mistakes for all completed mazes weighted by numbers of impasse mistakes (the closer the score is to 1 , the greater the child's difficulties).

Rey Complex Figure Test

* Rey copy Planning Index (IP): (P $* 100) / \mathrm{C}$

$\mathrm{P}$ is the total score of on Planning subtest and is out of 36 and $\mathrm{C}$ is the total score on the spontaneous copy of the Rey figure and is out of 36

VCI: Verbal Comprehension Index; FRI: Fluid Reasoning Index; VSI: Visual-Spatial Index; WMI: Working Memory Index; PSI: Processing Speed Index; VMI: Visuomotor Integration. 


\subsection{Procedure}

The young boy was initially referred for a neuropsychological evaluation that occurred throughout two outpatient visits at a private hospital in Beirut. Following the consent of his parents, the child's verbal consent, and the approval of the appropriate board of ethics, a third appointment was scheduled with the child to administer the CEF-B. Tests were administered at once, with one 15-minute break in the middle of the session. The battery of tests was administered to the child in that sequence: 8 Mazes test, Stroop test, Visuospatial updating test, Child Tapping test, Rey Complex Figure Test, TMT, KCST, Verbal updating test. The child's parents provided consent for publication of the following case.

\subsection{Statistical analysis}

Analysis of the patient's performance on the CEF-B was conducted using the Crawford-Howell (1998) t-test for case-control comparisons [27]. The patient's raw scores were compared to the normative scores of 42 typically developed Lebanese children matched for age. They were not matched for gender since, based on collected Lebanese data, gender did not have a significant influence on children's EF performance (Roukoz et al., 2020, manuscript under review). The same statistical procedure was used to analyze the parental ratings of Anthony's behavior on the BRIEF. Scores were considered in the impaired range when they were 1.64 standard deviation below the mean of the healthy controls. Regarding the other performancebased tests, scaled scores, Z-scores, index scores, and percentiles were generated by comparing the child with the normative data provided by the tests. Table 2 shows values of scores considered as impaired. 
Table 2: values of scores in the average and impaired range

\begin{tabular}{lll}
$\begin{array}{l}\text { Standardized } \\
\text { Scores }\end{array}$ & $\begin{array}{l}\text { Average Range of } \\
\text { Scores }\end{array}$ & Impaired range scores \\
\hline & & \\
Scaled Score (ScS) & 8 to 12 & below 5 \\
Standard Score (SS) & 90 to 109 & below 75 \\
Z-score (z) & -0.67 to +0.67 & below -1.64 \\
Percentile (\%ile) & 16 to 85 & below 5 \\
\hline
\end{tabular}

\section{RESULTS}

\subsection{Psychometric test results}

Table 3 shows Anthony's scores on neuropsychological test batteries administered.

Table 4 shows Anthony's scores on the CEF-B and table 5 shows his scores on the BRIEF (Parent form).

Table 3. Results on the neuropsychological test measures organized by tests $\underline{\text { administered }}$

\begin{tabular}{lccc}
\hline Wechsler Intelligence Scale for Children, Fifth Edition (WISC-V) & \\
\hline Scale & $\begin{array}{c}\text { Standard } \\
\text { Scores }\end{array}$ & Percentile & Range \\
\hline VCI & $\mathbf{6 9 * *}$ & $\mathbf{2}$ & Impaired \\
Similarities & $5^{*}$ & 5 & Borderline \\
Vocabulary & $4^{*}$ & 2 & Borderline \\
VSI & $\mathbf{8 1}$ & $\mathbf{1 0}$ & Low Average \\
Block Design & 8 & 25 & Average \\
Visual Puzzles & $5^{*}$ & 5 & Borderline \\
FRI & $\mathbf{8 5}$ & $\mathbf{1 6}$ & Low Average \\
Matrix Reasoning & $4^{*}$ & 2 & Borderline \\
Figure Weights & 11 & 63 & Average \\
WMI & $\mathbf{6 9 * *}$ & $\mathbf{2}$ & Impaired \\
Digit Span & $3^{* *}$ & 1 & Impaired
\end{tabular}




\begin{tabular}{|c|c|c|c|}
\hline Picture Span & 6 & 9 & Low Average \\
\hline PSI & $77 *$ & 6 & Borderline \\
\hline Coding & 6 & 9 & Low Average \\
\hline Symbol Search & 6 & 9 & Low Average \\
\hline Full Scale IQ & $73 *$ & 4 & Borderline \\
\hline \multicolumn{4}{|c|}{ Test of Everyday Attention in Children (Tea-ch) } \\
\hline Scale & & Percentile & Range \\
\hline Score! & & $<4 * *$ & Impaired \\
\hline Sky Search & & $2 * *$ & Impaired \\
\hline \multicolumn{4}{|c|}{ Beery-Buktenica Developmental Test of Visual-Motor Integration, Sixth Edition } \\
\hline Scale & $\begin{array}{c}\text { Standard } \\
\text { Scores }\end{array}$ & Percentile & Range \\
\hline Beery VMI & $64 * *$ & 0.8 & Impaired \\
\hline Visual Perception & 83 & 13 & Low Average \\
\hline Motor Coordination & $70 *$ & 2 & Borderline \\
\hline \multicolumn{4}{|l|}{ NEPSY-II } \\
\hline Scale & Scaled Scores & Percentile & Range \\
\hline Comprehension of Instructions & $1 * *$ & 0.1 & Impaired \\
\hline WG Semantic Total & 8 & 25 & Average \\
\hline
\end{tabular}

\begin{tabular}{lccc}
\hline \multicolumn{4}{l}{ Expressive One-Word Picture Vocabulary Test, Fourth Edition (EOWPVT-4) } \\
\hline Scale & Standard Score & Percentile & Range \\
\hline Total & $69^{* *}$ & 2 & Impaired \\
\hline Grooved Pegboard Test & & & \\
\hline Scale & Z-Score & Percentile & Range \\
\hline Dominant Hand* & -1 & 16 & Typical \\
Non-dominant Hand** & -1 & 16 & Typical \\
\hline
\end{tabular}

\section{Wechsler Individual Achievement Test - Third Edition (WIAT-III)}

Scale

Age- Grade-

Equivalence Equivalence

$\begin{array}{lccc}\text { Word Reading } & <6-0^{*} & <1.0 & \text { Impaired } \\ \text { Spelling } & <6-0^{*} & 1 & \text { Impaired }\end{array}$




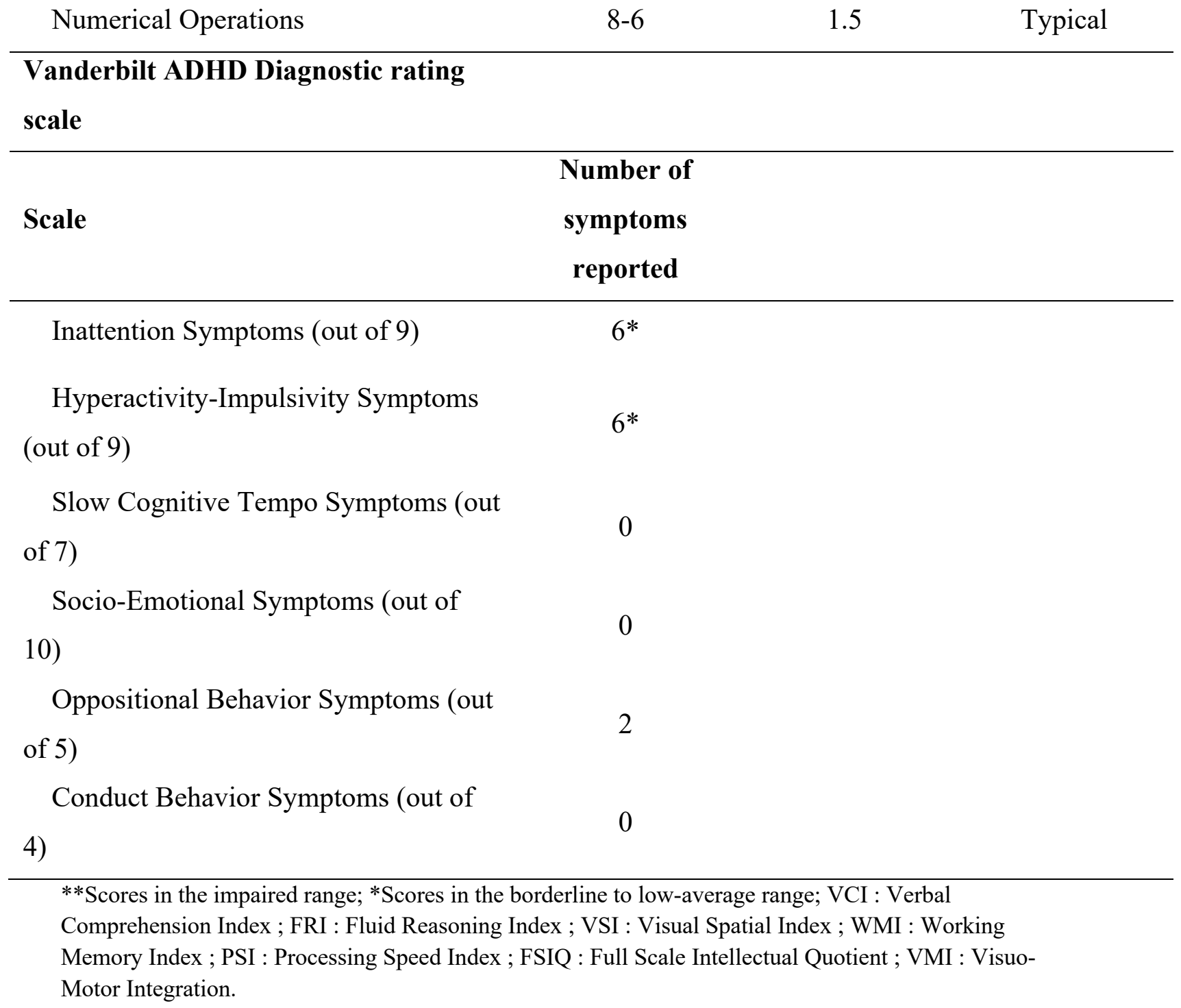

\subsection{Behavioral observation during testing:}

Anthony was extremely talkative, he had difficulties controlling his loud voice, and difficulties controlling his emotions. He interrupted adults while they were speaking, and he had difficulties controlling his urge to play with surrounding objects even when required not to. He needed constant repetitions of instructions and redirections to tasks. He sometimes completely lost focus and daydreamed. However, Anthony was cooperative and showed increased attention on tasks he judged motivating. He showed difficulties maintaining a back and forth conversation with the examiner. $\mathrm{He}$ 
also showed difficulties expressing himself fluently, exhibiting frequent word-finding difficulties.

\subsection{Language skills}

Anthony showed difficulties on most language tasks: on a task of naming pictures, he showed performance in the low range and showed word-finding difficulties even for familiar words. He also made semantic mistakes on familiar words. Anthony also showed impaired comprehension of sentences, receptive vocabulary knowledge and word reasoning. Those difficulties occurred in the context of observed difficulties expressing himself: Anthony made phonological mistakes in words (i.e. papillon $\rightarrow$

paillon; escalier $\rightarrow$ collier; aliment $\rightarrow$ animal) and responded to most questions with one-word or two-word sentences that were poorly constructed. He also showed difficulties finding his words and paused many times when talking. Finally, he displayed major difficulties understanding most questions and sustaining a back-andforth conversation with proper use of vocabulary words when using the French or Arabic language.

\subsection{Visual-spatial perception and motor skills}

Visual spatial processing tasks ranged from the borderline to the low-average range and were variable, mostly due to Anthony's behavioral dysregulation and inattention on most tasks. Motor dexterity was generally within the low-average range: Anthony showed low-average performance on a task of bilateral fine motor dexterity yet he showed impaired fine motor control (mainly due to his impulsive behaviors as he was rushing through most tasks requiring precision). He also showed low-average graphomotor speed. 


\subsection{Academic achievement}

On academic achievement measures, Anthony showed reading, writing, and calculation skills equivalent to skills of children in the beginning of Grade 1: he was not able to sound out all single letters and was able to read some familiar regular words yet made visual and inattentive mistakes (i.e. donc $\rightarrow$ done; blanc $\rightarrow$ balle). On tasks of spelling, Anthony was not able to write regular or irregular words (i.e., gros $\rightarrow$ go; main $\rightarrow$ me) and showed poor grapheme-phoneme associations as well as poor whole-words knowledge. In calculation skills, he was able to continue a number sequence and write numbers, yet he was not able to perform computations (additions, subtractions).

Table 4. Results on the Arabic version of the CEF-B subtests organized by EF

\begin{tabular}{lccc}
\hline Scale & t-score & Percentile & Range \\
\hline Inhibition & $1.3^{*}$ & & \\
Stroop time & $2.2^{* *}$ & $90.6 \% 0^{*}$ & Borderline \\
Stroop errors & $1.4^{*}$ & $98.1 \% * *$ & Impaired \\
Tapping GNG time & 0.9 & $91.4 \% *$ & Borderline \\
Tapping GNG errors & $3.1^{* *}$ & $91.7 \%$ & Typical \\
Tapping conflicting time & $4.1 * *$ & $99.7 \% * *$ & Impaired \\
Tapping Conflicting errors & & & Impaired \\
Flexibility & Interrupted & Interrupted & \\
TMT flexibility index & $2.222^{* *}$ & $98.13 \% * *$ & Impaired \\
NCST time & $1.844^{* *}$ & $96.04 \% * *$ & Impaired \\
NCST perseverative errors & & & \\
Working memory & 0.554 & $70.73 \%$ & Typical \\
Verbal updating baseline & -0.585 & $28.23 \%$ & Typical \\
Verbal updating score & -0.967 & $17.24 \%$ & Low-average \\
Visual updating baseline & -0.988 & $16.71 \%$ & Low-average \\
Visual updating score & & & \\
\hline & & & \\
\hline
\end{tabular}




\begin{tabular}{lccc}
\hline Planning & & & \\
Mazes completed items & 0.569 & $71.22 \%$ & Typical \\
Mazes completion time & 0.593 & $72.01 \%$ & Typical \\
Mazes weighted mean errors & $3.1 * *$ & $99.7 \% * *$ & Impaired \\
Rey copy planning Index & $4.156^{* *}$ & $99.98 \% * *$ & Impaired \\
\hline
\end{tabular}

**Scores in the impaired range; *Scores in the borderline range; NCST: New card Sorting Test ; TMT : Trail Making Test; GNG : Go No Go.

\subsection{Attention and EF (performance-based measures and rating scales)}

Anthony showed severe impairments on subtests from the TEA-Ch assessing visual and auditory sustained attention. He showed borderline scores on tasks assessing processing speed (WISC-V). On WISC-V subtests sensitive to EFs, Anthony showed impaired auditory working memory yet better performance, in the low-average range, on a task of visual working memory. Anthony's scores on the CEF-B also showed evidence of impaired performance across most measures. His performance ranged from the low to the low-average range across most measures: on tasks of inhibition, he showed superior Stroop time when compared to others his age showing a higher Stroop effect and therefore, greater difficulties when required to inhibit a prepotent verbal response. On the Tapping test assessing motor inhibition, Anthony showed impaired performance suggestive of impaired motor inhibition as well. On tasks of flexibility, he showed a significantly higher completion time on the KCST when compared to healthy controls. Number of perseverative errors on the KCST was in the high-average range (suggesting that Anthony made slightly more errors than typically expected at his age). The TMT was interrupted due to Anthony's inability to sequence numbers and letters.

On measures assessing working memory, Anthony's performance ranged from the typical to the low-average range on both tasks of visual and verbal updating. On subtests assessing his planning abilities, his performance was impaired on both 
measures: on the Mazes subtest, Anthony's completion time and number of errors was significantly higher than that of healthy controls. Finally, on the Rey Copy Planning task, Anthony significantly benefitted from the planning aid to improve his drawing suggesting planning difficulties.

On the BRIEF parental rating scale, Anthony's parents reported behavioral problems related to impairments on the following clinical scales: Inhibition, Emotional Control, Working Memory, Plan/Organize, and Monitor. He showed borderline-high problems in Organization of Materials clinical scale. Anthony also showed clinically significant scores on all the BRIEF Indexes: Behavioral Regulation Index, Metacognitive Index, and General Executive Composite.

On the Vanderbilt questionnaire, Anthony's parents reported symptoms of inattention (6/9), hyperactivity/impulsivity (6/9), and oppositional behaviors (2/5) that are impacting his performance at school and at home.

Table 5. Results on the Arabic version of the BRIEF (Parent form)

\section{BRIEF-Parents}

\begin{tabular}{lccc}
\hline Scale & t-score & Percentile & Range \\
\hline Inhibition & $2.681^{* *}$ & $99.43 \% * *$ & Problematic \\
Shift & 1.229 & $88.61 \%$ & Typical \\
Emotional control & $3.195 * *$ & $99.85 \% * *$ & Problematic \\
BRI & $2.885^{* *}$ & $99.66 \% * *$ & Problematic \\
Initiate & 1.342 & $90.57 \%$ & Typical \\
Working memory & $3.031^{* *}$ & $99.76 \% * *$ & Problematic \\
Plan/Organize & $2.609^{* *}$ & $99.32 \% *$ & Problematic \\
Org Materials & $1.509^{*}$ & $92.96 \% *$ & Problematic \\
Monitor & $1.751^{* *}$ & $95.54 \% * *$ & Problematic \\
MI & $2.475^{* *}$ & $99.07 \% * *$ & Problematic \\
GEC & $2.932^{* *}$ & $99.70 \% * *$ & Problematic \\
\hline
\end{tabular}

**Scores in the impaired range; *Scores in the borderline range; BRIEF: Behavior Rating Inventory of Executive Functions; BRI: Behavior Regulation Index; MI: Metacognitive Index. 


\subsection{Intellectual abilities}

Anthony's general intellectual abilities were in the borderline range of functioning. Nonetheless, his full-scale IQ was not an appropriate estimate of his true intellectual abilities as it was significantly impacted by his inattention and behavioral dysregulation and was heterogeneous across measures. Anthony showed better fluid reasoning and visual spatial perception (in the low-average range) when compared to his performance on tasks of verbal reasoning and on other tasks sensitive to attention and $\mathrm{EF}$ (which were in the impaired range).

\section{DISCUSSION}

This report describes the cognitive profile of a right-handed 8-year old boy with a history of refractory FLE who underwent a right frontal craniotomy in the context of right frontal cortical dysplasia 12 months prior to his assessment.

The objective of the present case study was to evaluate, through a preliminary single case study, the sensitivity of the CEF-B ant the BRIEF (Parent form) adapted to the Lebanese children, on a Lebanese child with FLE. The second objective was to examine whether or not the Lebanese child with FLE shows a pattern of EF cognitive and behavioral dysfunctions similar to the profile of children typically described in Western children with FLE $[4,5,24]$.

Anthony's neuropsychological assessment showed primary impairments on tasks assessing his language skills, attention and EF, and general intellectual abilities, Regarding language and verbal skills, he showed impaired naming abilities, verbal fluency, and comprehension of instructions on administered measures. He also showed impaired ability to define vocabulary words and find similarities between 
words. Anthony's difficulties on language tasks occurred in the context of clinically observed difficulties expressing himself and understanding instructions. He showed difficulties finding his words, constructing words appropriately, using vocabulary words in their proper context, and understanding questions and instructions. These difficulties occur in the context of a history of a delay in acquisition of most language milestones. Anthony's current language skills and history of delays in verbal milestones are suggestive of a DSM 5 diagnosis of Language Disorder. Our results were similar to others reporting comparable difficulties in children with FLE. For instance, [6] observed that children with FLE differed from healthy controls on verbal tasks. Also, our results corroborated those of others reporting that children who have undergone surgical resection in the context of FLE frequently show declines in verbal fluency,verbal IQ, and naming abilities [28].

Regarding Anthony's EF and attention skills, he showed impaired performance on most performance-based tasks as well as on the BRIEF parental rating scale and the ADHD screening questionnaire (Vanderbilt ADHD Diagnostic rating scale). Regarding performance-based measures, on the CEF-B flexibility measures, there was significant differences between our clinical case and the healthy controls on the completion time and on the number of perseverative errors of the KCST as observed by other studies $[5,22,23,29]$. For instance, [22] reported more perseverative errors in a group of children with FLE when compared to a normative sample and to other children with TLE. On the other hand, the TMT could not be completed by the young boy given his poor academic achievements leading to poor automaticity when sequencing the alphabet letters and numbers. This illustrates some of the obstacles faced when administering the TMT to young children with atypical academic 
achievement. Indeed, the performance of children with reading difficulties on TMT Part B is likely to be affected by their slowness on alphabetical series [30]. About inhibition, Anthony showed impaired performance on the Tapping task assessing motor inhibition and on the Stroop test assessing verbal inhibition. On the Stroop task, he showed longer completion time and more errors when compared to healthy controls. [23] also used the Stroop test to evaluate cognitive control deficits of children with FLE and showed that $1 / 3$ of their sample was significantly slower than healthy controls on the reading condition of the Stroop test, while $16 \%$ showed performance in the impaired range on the interference condition. According to [23] the performance on the Stroop test and on the WCST (task similar to the KCST) correlated with behavioral difficulties (assessed through the inhibition scale of the BRIEF).

On the other hand, Anthony showed intact performance on tasks of verbal and visual updating assessed through the CEF-B and impairments on the WISC-V digit span subtest. Other studies showed impaired performance on working memory tasks in children with FLE [31]. The observed disparities between our results and those of others may be due to different methodological choices of each study. Indeed, while some studies used tasks of digit or picture spans to assess working memory [29], we used tasks of visual and verbal updating, which may require different aspects of working memory. However, most studies seem to agree on problematic behaviors related to working memory in daily life, which converged with our observations [21]. On tasks of planning, Anthony showed major impairments when comparing his performance to those of healthy controls on the 8 Mazes test and the Rey copy figure test. Similarly, [32] used a Maze task when conducting a single case study with a child with FLE and showed a significantly higher numbers of errors in the child with 
FLE when compared to healthy controls. [24] also observed planning impairments in children with FLE using computerized tasks similar to the Tower of London (CANTAB).

Furthermore, Anthony showed impaired performance on tasks assessing sustained and selective attention (TEA-Ch). Reduced attention span was described in children with FLE [33] and impaired attention is one of the most common consequence of all types of childhood epilepsy [34,35]. According to [34], inattention could be due to subclinical seizures, undiagnosed learning disabilities, disturbed sleep, adverse effect of antiepileptic medication, or due to an attention deficit disorder.

Regarding behavioral rating scales completed by Anthony's mother, she reported major behavioral difficulties. She rated as clinically significant subscales pertaining to problems inhibiting automatic and impulsive behaviors, controlling one's emotions, keeping information in mind for a short-time enough to work with them (working memory), planning and organizing one's time and tasks, and monitoring one's performance. Parental ratings of the GEC, BRI, and MI Indexes of the BRIEF were also significantly higher than those of healthy controls. Maternal reporting of Anthony's behavioral symptoms was consistent with some of our observations during the testing process. Indeed, Anthony showed difficulties inhibiting his impulsive behaviors, self-correcting his mistakes, organizing his materials, and quickly forgot instructions. [25] also showed significant differences between children with FLE and healthy controls on Task Monitor, Plan/Organize, and Working Memory. They also observed major problems related to shifting whereas such difficulties were not reported by Anthony's mother. Similar to our findings, [21] observed on the BRIEF (Parent form) global executive impairment as indicated by a significantly high score 
on the GEC index. According to the same study, the onset of epilepsy at a younger age, the number of anti-epileptic drugs prescribed, and the duration of the epilepsy were correlated to a worse dysexecutive outcome as assessed by the BRIEF parental and teacher's ratings. Those risk factors may have worsened Anthony's dysexecutive behavioral presentation as he was reported to have started showing focal seizures early, at the age of 9 months, and his seizures were uncontrolled for approximately 7 years. Results obtained by Anthony on performance-based EF measures and the parental ratings on different clinical subscales of the BRIEF were not consistent across EF domains. Based on a performance-based assessment of working memory, Anthony showed intact performance whereas his parents rated major problems with working memory in daily life. Also, Anthony showed impaired performance on performance-based tests of flexibility and shifting whereas he was rated as typical in those areas by his mother. Regarding planning and inhibition, results on both performance-based tests and behavioral rating scales matched. Other studies showed significant associations between performance-based measures and parental ratings of EF impairments using the BRIEF yet each test result was not associated with its respective clinical scale on the BRIEF [36]. Therefore, [15] stresses on the importance of associating both performance-based tools and scales when assessing EF. Indeed, performance-based tests, being administered in an artificially structured environment, may not fully represent the child's performance in his natural setting. Interestingly, Anthony was reported by his parents to perform better in structured one-on-one settings with constant redirections provided (similar to the assessment situation) rather than in less structured class or home environments. 
Finally, based on the Vanderbilt ADHD Diagnostic rating scale completed by Anthony's parents, it was highly suggestive of ADHD, showing symptoms of inattention and hyperactivity/impulsivity impacting his functioning in the home and school settings. Anthony's mother also reported oppositional/conduct behaviors, impulsivity and major difficulties controlling his emotions. Behavioral observation during his assessment corroborated mother's reported symptoms on scales. Indeed, Anthony showed major behavioral disturbances, poor emotional control, irritability, oppositional behaviors, difficulties sustaining his attention and staying on task, major distractibility, and hyperactivity throughout his assessment. ADHD is a common clinical manifestation in children with FLE with some studies having observed an incidence of ADHD in $59 \%$ of children with FLE [37]. In fact, EF deficits have been associated with externalizing and internalizing behaviors [38,39]. Therefore, Anthony's symptoms of hyperactivity, impulsivity, dysregulated emotions, and oppositional behaviors may be secondary to his EF impairments and part of the same clinical presentation defined as a dysexecutive syndrome.

Dysexecutive syndromes are often described in children with FLE [21,22] and are generally not attributed to general intellectual impairments [3]. Symptoms are typically persistent over time and may worsen following resective surgery, despite improvement of seizure frequency [40].

Regarding Anthony's general intellectual abilities, they were in the borderline range of functioning. Nonetheless, his full-scale IQ was not an appropriate estimate of his true intellectual abilities as it was significantly impacted by his inattention and behavioral dysregulation and was heterogeneous across measures. Anthony showed better fluid reasoning and visual spatial perception (in the low-average range) when 
compared to his performance on tasks of verbal reasoning and on other tasks sensitive to attention and $\mathrm{EF}$ (which were in the impaired range).

Lastly, academic achievement measures revealed that Anthony's difficulties are resulting in major academic problems. Indeed, Anthony was showing below-age and grade performance on most academic measures. [41] showed strong correlations between EF and academic achievements on both math and literacy skills. They suggested that EF skills, involving the creation and implementation of a plan, selfmonitoring, and cognitive flexibility, are all important components of school success. Based on teacher's verbal reporting, Anthony was described as having difficulties planning ahead and finding strategies in problem solving tasks, changing strategies when unsuccessful in a problem-solving task, generalizing information learned to different contexts, retrieving learned information during tests, switching from one task to another, and finding out how to solve novel problems. In addition, he was reported to make many inattentive and impulsive mistakes when completing worksheets. Therefore, most of Anthony's academic impairments seem to be associated to his executive functioning problems. While Anthony's academic achievement measures were impaired across areas, he showed worse performance on literacy skills when compared to his math skills suggesting a possible additional DSM 5 diagnosis of Specific Learning Disorder (SLD) with impairments in reading and written expressions. Specific reading and writing impairments were described in children with FLE [42] and were attributed to impairments on phonological processing skills. Nonetheless, it is difficult, at this point, to confirm a diagnosis of SLD given Anthony's major cognitive and behavioral impairments preventing him to learn ageappropriate academic skills at an appropriate pace. 
The present single-case study showed a pattern of EF cognitive and behavioral EF dysfunctions as described in Western children with FLE $[4,5,24]$. This study also showed preliminary evidence suggesting that the CEF-B tests of inhibition, flexibility, and planning as well as the BRIEF (Parent form) were able to discriminate between the patient with FLE and the healthy controls. Indeed, Anthony showed evidence of impairment in inhibition, flexibility, and planning using the Stroop test, the Child Tapping test, the 8 Mazes test, the KCST, and the Rey figure test. However, he showed no impairments using the verbal and visual updating tests while working memory difficulties were described in children with FLE [31]. This may suggest that some aspects of working memory tests are a relative strength in the young boy's profile and may serve as compensatory mechanisms in his prospective treatment plan. In view of the above, the results were explained to the parents and the young boy and specific recommendations were provided to both. Anthony was recommended to continue speech therapy to improve his vocabulary knowledge, sentence structure, as well as pre-reading and pre-writing skills. He was also recommended to engage in behavioral therapy aiming at improving the young boy's emotional and behavioral dysregulation and provide parental tips for better behavioral management at home. For example, parents were recommended to ensure generalization of the skills learned in therapy by practicing them at home. They were also recommended to value structure in the home setting through, for example, structured schedules, organized closets, and encouraging Anthony to organize his backpack independently. Regarding his academic functioning, Anthony was suggested to enroll in an inclusive special education setting and benefit from an Individualized Educational Plan (IEP) tailored to meet his specific needs. The presence of a shadow teacher was also suggested to help achieve the IEP goals. The need for in-class accommodations was also discussed 
with his school counselor and it was recommended Anthony receives pullout reinforcement sessions in French and Arabic literacy skills. We also suggested Anthony should be seated near his instructor and preferably away from other potential distractions and have the opportunity to work in quiet work areas. Furthermore, due to his language and executive difficulties, it was recommended he benefits from a oneto-one setting when given instructions. We also recommended coupling all written instructions with oral directions provided by Anthony's teacher. We advised providing close monitoring and intermittent, discrete prompting to ensure that he stays on task and attends to relevant information. We also proposed allowing Anthony to complete evaluations with the help of a human reader and allowing him to provide spoken answers to test questions rather than written.

\section{CONCLUSION}

This is the first published study describing the neuropsychological profile of a Lebanese child with FLE using various neuropsychological measures. Most importantly, it is the first clinical application of the Arabic adaptation of the CEF-B on a Lebanese child. Through this preliminary single case study in which a Lebanese child with FLE was assessed using Arabic adaptations of the CEF-B and the BRIEF, the adapted tools seem to show promising preliminary results regarding their sensitivity to executive difficulties secondary to FLE. Future group studies will eventually be conducted to evaluate the sensitivity of this tool on executive dysfunctions accompanying FLE.

On the other hand, this case study allowed us to understand the specific cognitive profile potentially accompanying children with FLE and define their specific needs, 
taking us one step closer to improving neuropsychological services for Lebanese children with epilepsy.

\section{REFERENCES}

[1] Panayiotopoulos CP. Syndromes of idiopathic generalized epilepsies not recognized by the international league against epilepsy. Epilepsia 2005. https://doi.org/10.1111/j.1528-1167.2005.00314.x.

[2] Braakman HMH, Vaessen MJ, Hofman PAM, Debeij-Van Hall MHJA, Backes WH, Vles JSH, et al. Cognitive and behavioral complications of frontal lobe epilepsy in children: A review of the literature. Epilepsia 2011. https://doi.org/10.1111/j.1528-1167.2011.03057.x.

[3] Riva D, Avanzini G, Franceschetti S, Nichelli F, Saletti V, Vago C, et al. Unilateral frontal lobe epilepsy affects executive functions in children. Neurol Sci 2005. https://doi.org/10.1007/s10072-005-0469-7.

[4] Verche E, San Luis C, Hernández S. Neuropsychology of frontal lobe epilepsy in children and adults: Systematic review and meta-analysis. Epilepsy Behav 2018. https://doi.org/10.1016/j.yebeh.2018.08.008.

[5] Hernandez MT, Sauerwein HC, Jambaqué I, De Guise E, Lussier F, Lortie A, et al. Deficits in executive functions and motor coordination in children with frontal lobe epilepsy. Neuropsychologia 2002. https://doi.org/10.1016/S00283932(01)00130-0.

[6] Law N, Widjaja E, Smith M Lou. Unique and shared areas of cognitive function in children with intractable frontal or temporal lobe epilepsy. Epilepsy Behav 2018. https://doi.org/10.1016/j.yebeh.2017.12.035.

[7] Diamond A. Executive functions. Annu Rev Psychol 2013. 
https://doi.org/10.1146/annurev-psych-113011-143750.

[8] Berlin L, Bohlin G. Response Inhibition, Hyperactivity, and Conduct Problems Among Preschool Children. J Clin Child Adolesc Psychol 2002. https://doi.org/10.1207/S15374424JCCP3102_09.

[9] Chasiotis A, Kiessling F, Campos D, Hofer J. Theory of mind and inhibitory control in three cultures: Conflict inhibition predicts false belief understanding in Germany, Costa Rica and Cameroon. Int J Behav Dev 2006. https://doi.org/10.1177/0165025406066759.

[10] Lahat A, Todd RM, Mahy CEV, Lau K, Zelazo PD. Neurophysiological correlates of executive function: A comparison of european-canadian and chinese-canadian 5-year-old children. Front Hum Neurosci 2010. https://doi.org/10.3389/neuro.09.072.2009.

[11] Sabbagh MA, Xu F, Carlson SM, Moses LJ, Lee K. The development of executive functioning and theory of mind: A comparison of Chinese and U.S. preschoolers. Psychol Sci 2006. https://doi.org/10.1111/j.14679280.2005.01667.x.

[12] Wilson SJ, Baxendale S, Barr W, Hamed S, Langfitt J, Samson S, et al. Indications and expectations for neuropsychological assessment in routine epilepsy care: Report of the ILAE Neuropsychology Task Force, Diagnostic Methods Commission, 2013-2017. Epilepsia 2015. https://doi.org/10.1111/epi.12962.

[13] Vogt VL, Äikiä M, del Barrio A, Boon P, Borbély C, Bran E, et al. Current standards of neuropsychological assessment in epilepsy surgery centers across Europe. Epilepsia 2017. https://doi.org/10.1111/epi.13646.

[14] Modi AC, Gutierrez-Colina AM, Wagner JL, Smith G, Junger K, Huszti H, et 
al. Executive functioning phenotypes in youth with epilepsy. Epilepsy Behav 2019. https://doi.org/10.1016/j.yebeh.2018.11.026.

[15] Er-Rafiqi M, Roukoz C, Le Gall D, Roy A. Les fonctions exécutives chez l'enfant: Développement, influences culturelles et perspectives cliniques $=$ Executive functions in children: Development, cultural influences and clinical perspectives. Rev Neuropsychol Neurosci Cogn Clin 2017.

[16] Ardila A, Rosselli M, Matute E, Guajardo S. The influence of the parents' educational level on the development of executive functions. Dev Neuropsychol 2005. https://doi.org/10.1207/s15326942dn2801_5.

[17] Fernández AL, Marcopulos BA. A comparison of normative data for the Trail Making Test from several countries: Equivalence of norms and considerations for interpretation: Cognition and Neurosciences. Scand J Psychol 2008. https://doi.org/10.1111/j.1467-9450.2008.00637.x.

[18] Borsa JC, Damásio BF, Bandeira DR. Cross-cultural adaptation and validation of psychological instruments: Some considerations. Paideia 2012. https://doi.org/10.1590/1982-43272253201314.

[19] Last BS, Lawson GM, Breiner K, Steinberg L, Farah MJ. Childhood socioeconomic status and executive function in childhood and beyond. PLoS One 2018. https://doi.org/10.1371/journal.pone.0202964.

[20] Law N, Smith ML, Widjaja E. Thalamocortical connections and executive function in pediatric temporal and frontal lobe epilepsy. Am J Neuroradiol 2018. https://doi.org/10.3174/ajnr.A5691.

[21] Campiglia M, Seegmuller C, Le Gall D, Fournet N, Roulin JL, Roy A. Assessment of everyday executive functioning in children with frontal or temporal epilepsies. Epilepsy Behav 2014. 
https://doi.org/10.1016/j.yebeh.2014.07.023.

[22] Riccio CA, Pliego JA, Cohen MJ, Park Y. Executive Function Performance for Children With Epilepsy Localized to the Frontal or Temporal Lobes. Appl Neuropsychol Child 2015. https://doi.org/10.1080/21622965.2014.923774.

[23] van den Berg L, de Weerd A, Reuvekamp M, van der Meere J. Cognitive control deficits in pediatric frontal lobe epilepsy. Epilepsy Behav 2020. https://doi.org/10.1016/j.yebeh.2019.106645.

[24] Verche E, Cairos M, Marrero-Abrante R, Hernndez S. Neuropsychological assessment of executive functions in children and adolescents with frontal lobe epilepsy. Epilepsia 2011. https://doi.org/http://dx.doi.org/10.1111/j.15281167.2011.03207.x.

[25] Black CL, Shih SW, Sepeta LN, Facella-Ervolini JM, Isquith PK, Berl MM. Everyday executive function in focal onset pediatric epilepsy on the parentreport BRIEF2. Child Neuropsychol 2019. https://doi.org/10.1080/09297049.2018.1424326.

[26] Roy A, Le Gall D, Roulin J-L, Fournet N. Les fonctions exécutives chez l'enfant: approche épistémologique et sémiologie clinique. Rev Neuropsychol Neurosci Cogn Clin 2012. https://doi.org/10.1684/nrp.2012.0242.

[27] Crawford JR, Garthwaite PH. Investigation of the single case in neuropsychology: Confidence limits on the abnormality of test scores and test score differences. Neuropsychologia 2002. https://doi.org/10.1016/S00283932(01)00224-X.

[28] Risse GL. Cognitive outcomes in patients with frontal lobe epilepsy. Epilepsia 2006. https://doi.org/10.1111/j.1528-1167.2006.00699.x.

[29] Longo CA, Kerr EN, Smith M Lou. Executive functioning in children with 
intractable frontal lobe or temporal lobe epilepsy. Epilepsy Behav 2013. https://doi.org/10.1016/j.yebeh.2012.11.003.

[30] Närhi V, Räsänen P, Metsäpelto RL, Ahonen T. Trail making test in assessing children with reading disabilities: A test of executive functions or content information. Percept Mot Skills 1997. https://doi.org/10.2466/pms.1997.84.3c.1355.

[31] Owen AM, Morris RG, Sahakian BJ, Polkey CE, Robbins TW. Double dissociations of memory and executive functions in working memory tasks following frontal lobe excisions, temporal lobe excisions or amygdalohippocampectomy in man. Brain 1996. https://doi.org/10.1093/brain/119.5.1597.

[32] Charbonnier V, Roy A, Seegmuller C, Gautier A, Le Gall D. Étude d'un cas de syndrome dysexécutif à prédominance cognitive chez un enfant présentant une épilepsie frontale symptomatique. Rev Neuropsychol Neurosci Cogn Clin 2011. https://doi.org/10.1684/nrp.2011.0161.

[33] Patrikelis P, Angelakis E, Gatzonis S. Neurocognitive and behavioral functioning in frontal lobe epilepsy: A review. Epilepsy Behav 2009. https://doi.org/10.1016/j.yebeh.2008.09.013.

[34] Schubert R. Attention deficit disorder and epilepsy. Pediatr Neurol 2005. https://doi.org/10.1016/j.pediatrneurol.2004.06.007.

[35] Dunn DW, Kronenberger WG. Childhood Epilepsy, Attention Problems, and ADHD: Review and Practical Considerations. Semin Pediatr Neurol 2005. https://doi.org/10.1016/j.spen.2005.12.004.

[36] Toplak ME, West RF, Stanovich KE. Practitioner Review: Do performancebased measures and ratings of executive function assess the same construct? J 
Child Psychol Psychiatry Allied Discip 2013.

https://doi.org/10.1111/jcpp.12001.

[37] Zhang DQ, Li FH, Zhu XB, Sun RP. Clinical observations on Attention-Deficit Hyperactivity Disorder (ADHD) in children with frontal lobe epilepsy. J Child Neurol 2014. https://doi.org/10.1177/0883073812470004.

[38] Roth RM, Isquith PK, Gioia GA. Assessment of executive functioning using the behavior rating inventory of executive function (BRIEF). Handb. Exec. Funct., 2014. https://doi.org/10.1007/978-1-4614-8106-5_18.

[39] van den Berg L, de Weerd A, Reuvekamp M, Hagebeuk E, van der Meere J. Executive and behavioral functioning in pediatric frontal lobe epilepsy. Epilepsy Behav 2018. https://doi.org/10.1016/j.yebeh.2018.07.022.

[40] Chieffo D, Lettori D, Contaldo I, Perrino F, Graziano A, Palermo C, et al. Surgery of children with frontal lobe lesional epilepsy: Neuropsychological study. Brain Dev 2011. https://doi.org/10.1016/j.braindev.2010.06.006.

[41] Best JR, Miller PH, Naglieri JA. Relations between executive function and academic achievement from ages 5 to 17 in a large, representative national sample. Learn Individ Differ 2011. https://doi.org/10.1016/j.lindif.2011.01.007.

[42] Vanasse CM, Béland R, Carmant L, Lassonde M. Impact of childhood epilepsy on reading and phonological processing abilities. Epilepsy Behav 2005. https://doi.org/10.1016/j.yebeh.2005.05.008. 


\section{DISCUSSION GENERALE}

Les objectifs principaux de cette thèse consistaient d'abord à adapter des outils d'évaluation des FE auprès de la population libanaise sur la base des recommandations proposées par Borsa et al. (2012). Ensuite, il s'agissait d'étudier le développement des 4 principales FE, telles que définies par Diamond (2013), chez les enfants libanais âgés entre 6 et 12 ans. Le troisième objectif était d'analyser les potentielles influences du genre et du niveau d'éducation des parents sur la progression des FE. Enfin, le dernier objectif était de mener une application clinique auprès d'un enfant avec une épilepsie focale du lobe frontal à travers l'utilisation de la batterie FEE, afin de récolter des données préliminaires quant à la sensibilité des tâches exécutives adaptées en langue Arabe.

\subsection{L'adaptation méthodologique du protocole FEE}

La première étape ayant rendu possible l'étude de nos hypothèses était l'adaptation méthodologique du protocole FEE à la population libanaise.

Cette adaptation a été menée en suivant les recommandations proposées par Borsa et al. (2012). Une première traduction a été réalisée par des experts neuropsychologues et linguistes fluents dans les deux langues. Par la suite, une traduction inverse par d'autres experts, suivie d'une étude pilote auprès de 10 enfants libanais ont été entreprises. Le travail de translation/back-translation, ayant été réalisé par des experts marocains, a abouti à un document présentant les consignes en Arabe Moderne Standard. L'adaptation dans cette forme de la langue Arabe présente l'avantage de pouvoir être utilisée dans plusieurs pays Arabes (à condition d'avoir mené un travail d'adaptation de l'outils dans le pays ciblé). Cependant, cette forme de la langue Arabe reste peu utilisée dans le quotidien, surtout chez les enfants libanais. En effet, la majorité des Libanais utilisent le dialecte libanais vernaculaire, faisant partie de l'Arabe Levantin, comme mode de communication au quotidien. L'Arabe Moderne Standard est souvent limité aux journaux, nouvelles télévisées, ou autres modes de communication officielle. Étant donné que les deux langues présentent des différences majeures au niveau syntaxique, morphologique et lexical (Holes, 2005), cette forme de l'Arabe reste peu accessible pour les enfants libanais. C'est pour cette raison que l'ensemble des instructions a dû être "réadapté" dans le dialecte local afin de simplifier et d'unifier les 
consignes. Ceci est souvent un problème propre à l'adaptation de tests neuropsychologiques dans les populations arabophones (Zeinoun et al., 2020). Afin de contrer ce problème, certains tests neuropsychologiques libanais, tel que le Verbal Memory Arabic Test (VMAT), ont été créés en utilisant le dialecte Libanais plutôt que l'Arabe Moderne Standard (Zeinoun et al. 2020). Ceci permet donc de limiter différents biais tels que des biais d'administration qui ont été décrits par Van de Vijver (1997).

Notre expérience avec la passation des épreuves du protocole FEE adapté en langue Arabe a démontré que cet outil présente de nombreuses qualités et trouve parfaitement sa place dans l'évaluation exécutive des enfants libanais. Cependant, certaines difficultés ont été notées dans la passation du Stroop en langue Arabe. Ce dernier était difficile pour certains enfants étant donné que la dénomination des couleurs et la lecture des planches était parfois mieux automatisées dans une autre langue. En effet, certains des enfants contrôles libanais nommaient parfois certaines couleurs en Français ou en Anglais avant de s'autocorriger et de nommer les couleurs en Arabe. Le Stroop test serait d'ailleurs plus coûteux cognitivement chez les enfants bilingues étant donné qu'ils seraient amenés à suppresser les activations de mots dans leur deuxième langue (Levy et al., 2007) lors de la dénomination des couleurs. L'interférence entre différents systèmes langagiers est d'ailleurs un problème inhérent à l'ensemble des tests neuropsychologiques administrés aux enfants bilingues (Rivera Mindt et al., 2008). Pour le reste du protocole, les enfants libanais ont montré une bonne compréhension des consignes et n'ont rapporté aucune ambiguïté majeure. Cependant, certains mots des consignes ont parfois dû être couplés à leurs équivalents dans une autre langue, notamment le nom des formes dans l'épreuve KCST. D'ailleurs, coupler les instructions en deux langues différentes est une pratique souvent utilisée dans l'évaluation neuropsychologique des enfants libanais afin d'assurer une compréhension adéquate (El Hassan, 2006).

\subsection{Le développement typique des FE chez les enfants libanais}

En se basant sur le modèle de développement des FE proposé par Diamond (2013), nous nous attendions à un développement des quatre domaines de FE évalués (l'inhibition, la flexibilité mentale, la MDT et la planification) entre 6 et 12 ans chez les enfants libanais. Nous nous attendions donc à une amélioration des performances réalisées par les enfants pour les variables d'inhibition, de flexibilité mentale, de planification et de MDT entre 6 et 12 ans.

Roukoz Cynthia | Développement des Fonctions Exécutives chez les Enfants 
Les données relatives à la population libanaise ont montré un effet principal de l'âge sur des mesures relatives aux différentes composantes exécutives validant ainsi notre première hypothèse.

Pour l'inhibition, nous avons observé une amélioration conséquente du temps de réalisation et du nombre d'erreurs sur le test de Tapping entre 6 et 12 ans. Le temps de réalisation de la tâche ainsi que le nombre d'erreurs conflictuelles étaient significativement différents entre les groupes d'âges 6-7 et 8-9. Les résultats se sont montrés stables entre les groupes d'âge 8-9 and 10-12. Nous observons ainsi une amélioration de l'inhibition motrice chez les jeunes enfants d'âge scolaire tel que cela a été observé par d'autres études utilisant des tâches similaires d'inhibition motrice (Brocki \& Bohlin, 2004; Klenberg et al., 2001). D’un autre côté, nous n'avons pas observé d'amélioration des performances entre 6 et 12 ans au test de Stroop alors qu'une amélioration a été clairement montrée par d'autres études réalisées auprès d'enfants d'âges scolaires (Bellaj et al., 2016; Lehto et al., 2003). Ces résultats sont probablement dùs à des biais résultant du manque d'automaticité des enfants libanais dans la dénomination et la lecture des couleurs en Arabe Moderne Standard. En effet, la sensibilité à l'interférence dans la tâche de Stroop peut être biaisée si la personne testée ne montre pas une bonne maîtrise de la lecture de la langue du test (MacLeod, 1992). Les enfants libanais, par leur éducation particulière favorisant l'apprentissage de la lecture et de l'écriture en Français ou en Anglais, tardent à automatiser leurs capacités de lecture et de dénomination en langue Arabe. Il est également important de rappeler que l'Arabe étant une langue diglossique, elle comporte deux versions différentes. Le Stroop-Arabe exige pour l'enfant de dénommer et lire les couleurs en Arabe Moderne Standard bien que cette version de l'Arabe reste très peu utilisée dans la vie quotidienne au Liban. Ces facteurs pourraient donc expliquer l'absence d'amélioration au test de Stroop et questionne donc l'utilisation de cet outil dans sa forme actuelle pour l'évaluation des capacités d'inhibition d'une réponse prépondérante.

En ce qui concerne la flexibilité mentale, les données relatives à la population libanaise ont montré une réduction du temps de réalisation au KCST, sans différences significatives dans le nombre d'erreurs commises. Nos résultats contredisent les résultats observés par Davidson et al. (2006) qui montrent une amélioration des 
performances (plus de catégories complétées et moins d'erreurs) sur une tâche similaire, entre l'âge de 4 et 15 ans malgré une augmentation graduelle du temps de complétion de la tâche. Selon Davidson et al. (2006), les enfants plus âgés auraient tendance à prendre plus de temps afin d'assurer de meilleures performances à la tâche. Le contraire a été observé auprès des enfants libanais : un temps de réalisation plus court avec l'âge malgré une non-amélioration des performances. Nous n'avons également pas observé d'amélioration entre 6 et 12 ans au TMT, contrairement aux résultats rapportés par d'autres études (Lee et al., 2014). Au vu des données de la littérature montrant un développement prolongé des capacités de flexibilité (Garon et al., 2008; Huizinga et al., 2006), nous pouvons supposer une amélioration plus tardive à ces tâches, possiblement après l'âge de 12 ans.

La MDT, évaluée à travers des tâches de mise à jour verbale et visuospatiale, a montré un développement précoce et prolongé des performances des enfants libanais. Nous avons observé une amélioration significative de leurs performances entre 6 et 12 ans. Aux tâches de mise à jour visuospatiale, nous avons noté une augmentation rapide des performances des enfants entre 6 et 9 ans et une stabilisation après 9 ans au vu de l'absence de différences significatives entre 9 et 12 ans. Aux tâches de mise à jour verbale, les enfants ont montré une amélioration continue de l'empan de lettres entre 6 et 12 ans ce qui rejoint la littérature montrant un développement continu et prolongé de la MDT jusqu'à l'adolescence (Best et al., 2009; Gathercole et al., 2004). Par exemple, Luna et al. (2004) ont observé le développement de la MDT parmi d'autres fonctions chez des enfants et adultes âgés de 8 à 30 ans et ont noté un développement progressif des performances aux tâches et une stabilisation à l'âge de 19 ans. Les différences observées entre l'amélioration des enfants aux tâches de MDT visuelle et verbale entre 6 et 12 ans rejoignent le postulat d'une MDT domaine-spécifique et d'une séparabilité de la MDT visuelle et verbale (Alloway et al., 2006).

Des résultats similaires ont été observés sur une tâche de planification (Labyrinthes). A travers ce paradigme, nous avons observé une nette amélioration entre nos 3 groupes d'âges, 6-7, 8-9, et 10-12 sur le temps de réalisation à cette épreuve et une amélioration continue entre 6 et 12 ans du nombre d'erreurs et du nombre de labyrinthes réussis. Ces résultats sont similaires aux observations de Sheppard et Cheatham (2017) qui ont également noté une diminution graduelle du nombre d'erreurs d'impasses entre 7 et 11 
ans. D'un autre côté, à la tâche de la copie de la figure de Rey, l'indice de planification n'a pas montré de différences significatives entre nos groupes d'âges contrairement aux résultats notés par d'autres études (Akshoomoff \& Stiles, 1995; Anderson et al., 2001; Martens et al., 2014).

Les enfants libanais ont donc montré un développement chronologique des FE entre 6 et 12 ans. L'amélioration de leurs performances à une tâche d'inhibition motrice était plus marquée chez les plus jeunes alors qu'aux tâches de MDT verbale, l'amélioration était continue entre 6 et 12 ans. De même, l'amélioration à une tâche de planification était continue entre 6 et 12 ans alors que la flexibilité mentale n'a montré qu'une amélioration du temps de réalisation d'un test sans progrès aux autres mesures. Ainsi, notre hypothèse postulant une amélioration aux tâches de FE entre 6 et 12 ans est vérifiée. Cependant, les différences développementales étaient non-synchrones, spécifiques à certaines tâches et variables selon la composante des FE évaluées.

\subsection{L'influence des facteurs sociodémographiques sur le développement des FE}

Le deuxième objectif de ce travail était d'analyser les influences sociodémographiques sur le développement des FE. A l'instar des données empiriques, nous avions supposé l'absence d'influence du genre sur le développement des FE (Arán-Filippetti \& Allegri, 2011; Armengol, 2002; Brocki \& Bohlin, 2004) et une influence positive du niveau d'éducation parental (Ardila et al., 2005; Last et al., 2018). Initialement, il était également prévu d'analyser l'influence du bilinguisme sur le développement des FE chez les enfants libanais. Ceci n'a pas été possible étant donné que, par le statut particulier des langues au Liban, les enfants libanais sont, pour la majorité, bilingues. En effet, l'école au Liban débute à 3 ans et les cursus scolaires sont enseignés soit en Français, soit en Anglais, encourageant les parents à exposer à minima leurs enfants à une deuxième langue afin de favoriser leur adaptation à la garderie et à l'école. Ainsi, le groupe d'enfants ayant participé à cette étude était homogène en termes de compétences langagières rendant impossible l'étude du bilinguisme sur le développement des FE.

En ce qui concerne l'influence du genre sur les performances aux tests de FE, nous avons observé, sur une tâche de planification (Labyrinthes), un temps de réalisation 
plus court chez les garçons. Inversement, les filles étaient plus rapides que les garçons sur une tâche d'inhibition motrice (Tapping). Nous n'avons observé aucune différence significative du genre sur les autres mesures. Ainsi, chez les enfants libanais, à l'instar des observations menées auprès des enfants Tunisiens (Bellaj et al. 2015), Argentins (Filippetti, 2011) et Mexicains (Armengol, 2002 ; Ardila et al., 2011), le genre de l'enfant ne semble pas globalement influencer de manière significative les performances exécutives. Ces résultats permettent de supposer que les garçons et les filles libanais auraient donc accès à des stimulations et des opportunités similaires, permettant un développement homogène entre les deux sexes. Ainsi, malgré les perpétuels problèmes liés aux inégalités envers les femmes dans les pays MoyenOrientaux (Krafft \& Alawode, 2018), au Liban, nous ne retrouvons pas de résultats reflétant ces inégalités, contrairement aux observations de Thorell et al. (2013) auprès des enfants Iraniens.

Notre deuxième hypothèse supposait une influence significative et positive du niveau d'éducation maternel et paternel sur le développement des FE des enfants libanais. Nous avons retrouvé un effet significatif du niveau d'éducation parental sur l'efficience exécutive des enfants libanais à travers plusieurs mesures, comme le synthétise la table 13.

Table 13. Effet du niveau d'éducation parental sur les tests de FE

\begin{tabular}{cc}
\hline $\begin{array}{c}\text { Variables montrant un effet significatif du niveau } \\
\text { d'éducation maternel }\end{array}$ & $\begin{array}{c}\text { Variables montrant un effet significatif du } \\
\text { niveau d'éducation paternel }\end{array}$ \\
\hline $\begin{array}{c}\text { Inhibition: Tapping erreurs conflictuelles } \\
\text { Flexibilité: KCST erreurs perseveratives }\end{array}$ & $\begin{array}{c}\text { Flexibilité: KCST erreurs perseveratives } \\
\text { MDT: mise à jour verbal ligne de base }\end{array}$ \\
MDT: mise à jour visuospatiale score & MDT: mise à jour verbal score performance \\
performance & \\
Planification: labyrinthes complétés & Planification: labyrinthes temps total \\
Planification: labyrinthes erreurs &
\end{tabular}

Par exemple, sur la tâche du KCST, le niveau d'éducation de la mère et le niveau d'éducation du père étaient corrélés à plus d'erreurs perséveratives chez les enfants : les enfants de mères avec un niveau d'éducation plus bas ont montré significativement plus d'erreurs perséveratives que les enfants de mère avec un niveau d'éducation universitaire. Les mêmes résultats ont été observés pour le niveau d'éducation du père. 
Nous avons également observé un effet du niveau d'éducation de la mère et du père sur les performances de MDT visuelle et verbale : les enfants de mères moins éduquées ont montré des performances moindres sur une tâche de Mise à jour visuospatiale par comparaison aux enfants de mères avec un niveau d'education plus élevé. De plus, les enfants de pères moins éduqués ont montré des performances significativement plus faibles aux tâches de Mise à jour verbale et Mise à jour visuospatiale que les enfants de pères ayant un niveau d'éducation plus élevé. Ces résultats rappellent les résultats de Bellaj et al. (2015) qui ont observé, chez les enfants tunisiens, un effet du niveau d'éducation du père sur les performances aux tâches de MDT visuospatiale. Ardila et al. (2005) ont également observé un effet du niveau d'éducation parental sur l'efficience exécutive des enfants sur des tâches de fluence verbale et non-verbale, de flexibilité et sur des tâches d'abstraction chez les enfants âgés de 5 ans à 14 ans.

L'effet positif du niveau d'éducation parental sur le développement des FE a été discuté par plusieurs auteurs. Par exemple, Ardila et al. (2005) et Wilson et al. (2018) ont associé le niveau d'éducation parental élevé à un niveau intellectuel plus élevé permettant aux parents de promouvoir des activités stimulantes chez leurs enfants et favoriser ainsi leur développement cognitif. Ils ont également associé le niveau d'éducation plus élevé à un meilleur niveau socio-économique familial, facteur qui serait indépendamment associé à de meilleures performances exécutives chez les enfants (Ardila et al., 2005; Lipina \& Evers, 2017; Noble et al., 2015).

Ainsi, les résultats sont en faveur d'une validation de notre deuxième hypothèse supposant une influence positive du niveau d'éducation maternel et paternel sur le développement des FE et une influence non-significative du genre.

A l'échelle internationale et d'un point de vue interculturel, ces résultats viennent questionner les modélisations théoriques actuelles qui ne tiennent pas compte de la culture et du contexte (Dennis, 2006 ; Diamond, 2013 ; Lee et al., 2013) dans leurs conceptions du développement des FE. Nos observations nous mènent donc à nous interroger sur la généralisation de ces modèles dans différents contextes culturels et sociodémographiques. A l'échelle locale, ces résultats révèlent des données inquiétantes au vu du contexte libanais. Le niveau d'éducation parental est typiquement considéré comme étant un indicateur de statut socio-économique (Aarø et al., 2009). Actuellement, le Liban connait une crise socio-économique sans précédent qui a 
conduit à un appauvrissement significatif de la population libanaise. Il est estimé que $55 \%$ des familles libanaises vivent actuellement au seuil de la pauvreté. La Commission Economique et Sociale des Nations Unies pour l'Asie Occidentale rapporte qu'en un an seulement, un accroissement de la pauvreté extrême a été notée avec un passage de 8 à $23 \%$ de la population libanaise vivant en-dessous du seuil de la pauvreté (http://www.unescwa.org/). Ainsi, étant donné que le niveau socio-économique des familles libanaises influence le développement des FE des enfants, cet accroissement rapide de la pauvreté au Liban est susceptible d'entraîner des conséquences néfastes sur le développement exécutif des enfants libanais. Ceci s'inscrit dans un contexte de multiple crises, d'instabilité, et de traumas continuels auxquels font face les Libanais. Par exemple, l'explosion cataclysmique qu'a vécu le Liban le 4 août 2020 a entraîné une augmentation significative des états de stress post-traumatique chez les enfants et adolescents libanais déjà fragiles. Les études publiées après le début de la crise économique ont montré une prévalence de $6.2 \%$ de symptômes de dépression et d'anxiété chez les enfants libanais âgés de 8 ans et plus (Baroud et al., 2019) et une augmentation significative des idées suicidaires chez les adolescents libanais de 15 à 18 ans (Chahine et al., 2020). Ces troubles de santé mentale, associés à la crise socioéconomique libanaise, sont également susceptibles d'entraver le développement exécutif des enfants libanais (Beers \& De Bellis, 2002; Flaks et al., 2014; McDermott \& Ebmeier, 2009; Owens et al., 2012). En effet, les troubles exécutifs seraient associés à la severité des symptômes dépréssifs et post-traumatiques (Olff et al., 2014). Ces troubles exécutifs seraient conséquents aux altérations de structures du cortex préfrontal dorsolateral et ventromedian, secondaire à l'état de stress post-traumatique (Scott et al., 2015).

Ainsi, le contexte libanais, montrant un appauvrissement continu qui s'associe à un accroissement des troubles de santé mentale, est susceptible de montrer des conséquences à long-terme sur le développement des FE des enfants libanais. Ces risques devraient donc être étudiés et, dans la mesure du possible, prévenus, en ayant recours à des programmes de remédiation construits sur la base d'une analyse fine des observations réalisées dans des études locales, théoriquement construites et correctement conduites. 


\subsection{L'évaluation des FE chez un enfant libanais avec ELF}

L'intérêt clinique de cette thèse était d'aboutir à des outils de FE adaptés à la population Libanaise et pouvant être, à terme, utilisés dans différents contextes cliniques pédiatriques.

Dans le contexte d'une étude préliminaire de validité et de sensibilité clinique du protocole FEE adapté au contexte libanais, nous faisions l'hypothèse que des troubles de planification, de MDT, d'inhibition et de flexibilité seraient retrouvés chez un enfant avec une ELF (Culhane-Shelburne et al., 2002; Hernandez et al., 2002; Lassonde et al., 2000).

Le cas clinique inclus dans cette étude, que nous avons nommé Anthony, a révélé, dans l'évaluation neuropsychologique, des difficultés dans toutes les composantes langagières et une efficience intellectuelle en zone limite. Cependant le score de QI est difficilement interprétable, compte tenu des troubles du comportement, des déficits exécutifs, ainsi que des troubles du langage d'Anthony qui ont limité sa participation à certaines tâches. En effet, Anthony a montré des performances hétérogènes entre chaque indice du test d'efficience intellectuelle globale, rendant le score de QI global ininterprétable.

Anthony a également montré des difficultés exécutives pour la majorité des tâches de notre protocole FEE. Nous avons observé des déficits aux tests d'inhibition (Stroop et Tapping), de flexibilité (TMT et KCST) et de planification (Labyrinthe et figure de Rey) alors que les performances aux tâches de MDT étaient similaires aux performances des enfants contrôles. Sur le questionnaire BRIEF-parent visant une évaluation en vie quotidienne des FE, les parents d'Anthony ont rapporté des difficultés aux échelles cliniques évaluant l'inhibition, le contrôle émotionnel, la MDT, les capacités d'organisation et de planification, d'organisation de matériel, et le contrôle de soi. Les scores d'Anthony aux indices de régulation comportementale, de métacognition ainsi qu'à l'indice exécutif global étaient également significativement plus élevés que les scores des enfants du groupe contrôle. Anthony a également montré de nombreux symptômes d'inattention, d'hyperactivité/impulsivité et des comportements oppositionnels à un questionnaire complété par ses parents et évaluant les symptômes de TDA/H. De plus, l'observation comportementale d'Anthony durant 
l'évaluation ainsi que les plaintes rapportées par ses parents confirment les difficultés exécutives observées. En effet, tout au long des séances d'évaluation, Anthony s'est montré impulsif et hyperactif, il était opposant aux demandes de l'examinateur, avait du mal à se concentrer sur une même tâche, se montrait désorganisé dans son discours, et avait des propos inappropriés.

Ainsi, à l'instar de ce qui a été décrit dans la littérature, Anthony a montré des difficultés exécutives tant aux outils basés sur sa performance que sur les questionnaires d'évaluation des FE (Braakman et al., 2011; Campiglia et al., 2014 ; Hernandez et al., 2002 ; Riccio et al., 2015). Les déficits montrés par le biais des épreuves basées sur la performance ainsi qu'à travers une évaluation plus «écologique» des FE (BRIEF) étaient concordants pour certaines mesures mais pas pour d'autres. En effet, Anthony a montré des difficultés d'inhibition et de planification à travers les tests de performance et a également montré, selon le point de vue parental, des plaintes quotidiennes liées à ces domaines exécutifs. Cependant, les difficultés de flexibilité observées à travers le KCST ne concordaient pas avec les plaintes parentales rapportées au questionnaire BRIEF. De plus, Anthony a présenté des performances normales aux épreuves de MDT alors que ses parents ont rapporté des difficultés comportementales majeures à l'échelle de MDT de la BRIEF. D'ailleurs, plusieurs études ont, de même, trouver des divergences entre les résultats aux tests standardisés évaluant les FE et les échelles d'évaluation comportementale (Miranda et al., 2015 ; Toplak et al, 2013). D'ailleurs, les tests basés sur la performance et les échelles d'évaluation remplies par un informant et évaluant les capacités d'un enfant à compléter certaines tâches de la vie quotidienne ne viseraient pas nécessairement les même construits psychologiques (Toplak et al, 2013). En effet, si ces deux types d'outils évaluaient les mêmes construits, on s'attendrait à retrouver des corrélations entre les deux mesures. Par exemple, l'échelle d'inhibition de la BRIEF devrait être associée à des tests d'inhibition tel que le STROOP, ce qui n'est souvent pas le cas dans les études publiés (Saunders et al., 2018 ; Toplak et al., 2013) et n'était pas le cas dans notre étude. D’ailleurs, Toplak et al. (2013) ont analysé les résultats de 286 études ayant comme objectif d'observer les corrélations entre les outils évaluant la performance et les échelles de comportement dans la vie quotidienne. L'échelle la plus utilisée dans les études était la BRIEF. Selon leur étude, $24 \%$ des travaux seulement ont montré des corrélations entre les deux types de mesures, et les effets observés étaient assez réduits. Ils en ont donc conclu, compte tenu de la 
faible validité de convergence entre les deux types de mesures, que les échelles et les tests standardisés n'évalueraient pas nécessairement les même construits psychologiques. Ils ont émis l'hypothèse que les tests de performance permettraient d'évaluer le processus cognitif en tant que tel mais n'évalueraient pas la capacité de l'enfant à recruter ce processus cognitif quand nécessaire dans la vie quotidienne, afin de poursuivre un but déterminé. Ceci témoigne de l'importance d'une complémentarité entre les tests neuropsychologiques classiques basés sur la performance et les outils plus « écologiques » évaluant le comportement de l'enfant dans son quotidien. Cette complémentarité permettrait, en effet, de mieux comprendre l'impact du dysfonctionnement exécutif dans le quotidien de l'enfant et améliorer les plans de prise en charge proposés (Er Rafiqi et al., 2018).

Les difficultés cognitives et comportementales d'Anthony apparaissent donc au centre du tableau clinique d'Anthony et rappellent le versant pseudopsychopathique du tableau dysexécutif se caractérisant par des comportements d'irritabilité et d'agressivité, une intolérance à la frustration, une impulsivité, une labilité émotionnelle ainsi que des accès incontrôlables de violence (Roy et al., 2012).

Certains troubles comportementaux d'Anthony pourraient relever d'une interaction cognitivo-comportemental des deficits. Par exemple, certains symptômes d'impulsivité ou « rapid-response impulsivity» tel que defini par certains auteurs (Dawe et al., 2004 ; Mac Killop et al., 2016 ; Swann, 2010) ont été associés aux performances à des tests d'inhibition tels que le test Go No Go (Jauregi et al., 2018). D'un autre côté, d'autres formes d'impulsivité tel que la capacité de l'enfant à retarder une gratification ou «reward-delay impulsivity» ne corrélaient pas avec les performances aux tâches d'inhibition et seraient donc indépendants.

Les troubles de FE, autant sur le registre cognitif que comportemental ont été décrits par plusieurs auteurs comme relevant des lésions du lobe frontal (Chow, 2000; Floden et al., 2008; Grafman et al., 1996; Risse, 2006) et des perturbations affectives et comportementales se manifestent souvent au premier plan chez les enfants avec une ELF (Boon et al., 1988 ; Jambaqué \& Dulac, 1989), dépendamment des régions affectées. Le profil d'Anthony, montrant des difficultés diffuse affectant les deux registres, affectif et cognitif, laisse penser à des dysfonctionnements frontaux diffus, affectant les régions médiales, orbitaire et dorso-latérale du cortex préfrontal. 
Le profil cognitif d'Anthony a également montré des résultats suggérant la présence de déficits langagiers et d'un fonctionnement intellectuel en zone limite. Ces difficultés cognitives ont souvent été decrites chez les enfants avec ELF (Chieffo et al., 2011; Law, et al., 2018) et viennent compliquer l'expression clinique du syndrome dysexécutif de l'enfant.

Ainsi, on a principalement observé des résultats globalement inférieurs à la majorité des tests de FE, ce qui démontre une certaine sensibilité de la batterie à la pathologie chez un enfant libanais. Ces résultats nous permettent donc de vérifier un dysfonctionnement exécutif au niveau des quatre FE évaluées auprès d'un cas clinique libanais. Ce cas clinique est le premier cas publié décrivant un enfant libanais, évalué à l'aide d'outils de FE adaptés à la population libanaise, et décrivant son profil neuropsychologique et plus particulièrement, dysexécutif.

A travers cette vignette clinique, nous montrons des résultats préliminaires prometteurs quant à la qualité psychométrique des tests de FE adaptés à la langue Arabe.

Prospectivement, des échantillons plus larges et plus diversifiés, incluant des populations de malades, permettraient de mener des études afin d'aboutir à des normes pour les tests de FE propres à la population libanaise mais aussi de démontrer la sensibilité et la fidélité des mesures réalisées. 


\section{LIMITES ET PERSPECTIVES}

9.1. Limites

Ce travail de thèse est le premier de ce genre à s'intéresser au développement des FE chez les enfants libanais. Cependant, il présente plusieurs limites et ne représente, à ce stade, qu'un premier pas vers de futures études nécessaires tant sur le plan clinique que théorique.

Parmi les limites, notons l'échantillon restreint de notre étude ayant engendré une disparité importante des performances au sein de chaque sous-groupe. Cette disparité a possiblement biaisé certains résultats statistiques. Par ailleurs, nous avons suivi une méthode d'échantillonnage par convenance étant donné que chaque étudiant responsable de la passation des tests a recruté des enfants de son entourage communautaire. Cette méthode d'échantillonnage a été choisie en raison du manque de financement nous permettant d'élargir le recrutement en y intégrant des enfants de toutes les régions libanaises. En effet, les étudiants recrutés n'ont pas été rémunérés pour cette activité et ont donc dû limiter leurs passations, soit à leur région résidentielle, soit à leur village d'origine (Sud du Liban par exemple). Ceci pourrait limiter la représentativité de la population libanaise au sein de notre échantillon. En effet, compte tenu de l'hétérogénéité de la population libanaise, limiter l'échantillon à certaines régions de Beirut, Mont-Liban et du Sud du Liban exclut une partie conséquente de la population libanaise qui présente des particularités culturelles susceptibles d'influencer le développement des FE. De plus, notre échantillon n'a compté que des enfants issus d'écoles privés ce qui limite également la diversité au sein de notre échantillon, d'autant plus que le type d'école est un facteur susceptible d'influencer le développement des FE (Ardila et al., 2005; Jacobsen et al., 2017). Il est aussi important de prendre en compte les limites liées aux indicateurs du niveau socioéconomique des familles libanaises. Nous avions décidé, dans cette étude, d'évaluer le niveau socioéconomique à partir du niveau d'éducation parental. Cependant, compte tenu de la situation économique fragile du Liban et du taux de chômage important, plusieurs parents libanais présentent un niveau d'éducation universitaire, malgré une situation financière très précaire. De ce fait, d'autres indicateurs de niveau socio-économique, tels que les catégories salariales, auraient potentiellement montré des résultats différents, d'autant 
plus que plusieurs études ont montré une influence des échelles de salaires d'une famille sur le développement des FE des enfants (Filippetti, 2011; Kohen et al., 2002).

Une autre limite de cette étude est la disparité des compétences langagières des enfants constitutifs de notre échantillon. Étant donné que l'ensemble de notre échantillon est bilingue, nous n'avons pas pu étudier l'influence de ce facteur sur le développement des FE. Cependant, les enfants libanais restent différents dans leurs bilinguismes. Comme mentionné plus haut, les enfants libanais sont amenés à suivre un cursus scolaire en Français ou en Anglais alors que leur langue officielle est l'Arabe. De plus, l'Arabe est une langue diglossique et présente donc deux formes: une version enseignée dans les écoles et peu utilisée dans le quotidien, et une autre, utilisée dans la vie quotidienne mais absente des apprentissages scolaires. Ces particularités langagières mènent à certaines hétérogénéités dans les compétences langagières des enfants libanais et peuvent causer des biais dans les évaluations neuropsychologiques, comme illustré par notre expérience avec le test de Stroop.

\subsection{Perspectives}

Ce travail ne représente qu'un premier pas pour de futures études indispensables à une meilleure compréhension du développement des FE dans différents contextes culturels. Pour commencer, ce travail devrait être développé afin de permettre l'élaboration de normes locales libanaises pour les tests de FE adaptés au contexte local. Dans un deuxième temps, il serait également intéressant d'observer les effets d'autres facteurs sociodémographiques tels que l'effet du type d'école ou les catégories salariales des familles, qui ont également montré une influence sur le développement des FE chez l'enfant (Ardila et al. 2005; Hoff et al., 2003; Kohen et al., 2002). De plus, compte tenu de la situation économique fragile des familles Libanaises, plusieurs pères de familles sont amenés à émigrer et travailler dans des pays voisins, afin de subvenir aux besoins de leurs familles résidant au Liban. Il serait ainsi intéressant de questionner cette situation de vie sur le développement exécutif des enfants libanais. Des études ont montré une influence des familles monoparentales sur le développement exécutif (Sarsour et al., 2011) cependant, cette situation familiale singulière reste non-explorée.

Ce travail devrait également être complété par l'administration de questionnaires évaluant l'impact comportemental des troubles de FE dans différents contextes et permettant une représentation plus concrète des difficultés exécutives d'un enfant. En 
effet, les tests neuropsychologiques basés sur la performance pourraient manquer de sensibilité dans la mesure où ils ne reflèteraient pas nécessairement l'engagement des FE dans la vie quotidienne d'un enfant (Roy et al., 2012). A travers le projet FEE, le questionnaire BRIEF a été adapté à la langue Arabe et à la population libanaise et 100 passations du BRIEF-Parent ainsi que 70 passations du BRIEF-Enseignant ont été collectés jusque-là. Prospectivement, un étalonnage de la BRIEF-Arabe devrait être fait ainsi que des études supplémentaires permettant d'évaluer l'équivalence des construits évalués et vérifier que ce questionnaire évalue bien les même construits dans la langue cible que dans sa langue originale (ITC, 2018).

Finalement, à travers l'utilisation d'outils d'évaluation de FE adaptés à la population libanaise, l'évaluation des FE dans plusieurs contextes étiologiques sera donc possible. Prospectivement, l'évaluation du syndrome dysexécutif dans plusieurs contextes étiologiques permettrait d'abord de vérifier la sensibilité et la spécificité des outils adaptés en langue Arabe et au contexte libanais et permettrait éventuellement de mieux comprendre la sémiologie dysexécutive chez les enfants libanais et d'améliorer ainsi les prises en charge proposées. En effet, compte-tenu des influences sociodémographiques retrouvées auprès de la culture libanaise et des particularités culturelles de ce pays, il n'est pas interdit de penser que l'expression des troubles exécutifs sera différente d'autres pays de la région, ou d'autres régions du monde.

Enfin, dans la même lignée, il serait également intéressant, sur le plan théorique, de mener des études interculturelles afin de mieux comprendre les différences culturelles dans le développement des FE ainsi que les invariants des FE d'une culture à une autre. Comme mentionné par Roukoz et al. (2018), peu de travaux se sont intéressées aux différences interculturelles du développement des FE et les études s'étant attardées sur le sujet montrent plusieurs limites. Parmi les limites, plusieurs études n'ont pas contrôlé d'importantes variables sociodémographiques de la population étudiée (par exemple : Lahat et al., 2010 ; Imada et al., 2013). De même, certains travaux n'ont pas utilisé des tests adaptés à la population cible. Aussi, les différences méthodologiques entre les études ainsi que la multitude de tests utilisés ne permettaient pas d'aboutir à des conclusions claires (Roukoz et al., 2018). Afin de pallier à ce manque, le projet FEE a permis l'étude du développement des FE auprès de plusieurs cultures, sur la base d'une méthodologie commune, autorisant à l'avenir des comparaisons interculturelles. Ces 
comparaisons interculturelles permettront d'améliorer la compréhension et les modélisations actuelles du développement des FE en déterminant les différences ainsi que les invariants dysexécutifs entre une culture et une autre. 


\section{CONCLUSION}

Ce travail de thèse est le premier du genre à s'intéresser au développement des FE chez les enfants libanais. Il a ainsi permis de recueillir des informations préliminaires permettant de mieux comprendre comment les FE se développent avec l'avancée de l'âge chez les enfants libanais et quels sont les facteurs sociodémographiques susceptibles d'influencer leur développement. Cette étude a également abouti au développement d'outils d'évaluation des FE, adaptés en langue Arabe et à la population libanaise en particulier, en suivant une méthodologie rigoureuse permettant, à priori, de conserver les qualités psychométriques des tests adaptés. L'établissement de ces outils d'évaluation s'inscrit dans une phase critique pour le Liban. Comme mentionné plus haut, dans la situation dramatique politique, économique et sociale dans laquelle se trouve le pays, nous avons observé une augmentation conséquente des troubles de santé mentale chez les enfants et adolescents libanais (Baroud et al., 2019; Baroud et al., 2019; Chahine et al., 2020). Les enfants libanais d'âge scolaire rencontrent donc de nombreux obstacles, susceptibles d'entraver leur développement psychologique, d'autant plus que, comme nous l'avons démontré dans cette étude, le développement des FE chez les enfants libanais est particulièrement vulnérable au contexte socioéconomique des parents. De plus, les récents évènements au Liban sont venus accroître les besoins de services neuropsychologiques auprès de la population pédiatrique libanaise. Cette étude ayant aboutit à l'adaptation du protocole FEE auprès de la population libanaise permet ainsi une amélioration des services psychologiques au service des enfants libanais actuellement particulièrement vulnérables. 


\section{BIBLIOGRAPHIE}

Aarø, L. E., Flisher, A. J., Kaaya, S., Onya, H., Namisi, F. S., \& Wubs, A. (2009).

Parental education as an indicator of socioeconomic status: Improving quality of data by requiring consistency across measurement occasions. Scandinavian Journal of Public Health, 37 Suppl (2), 16-27.

https://doi.org/10.1177/1403494808086917

Akshoomoff, N. A., \& Stiles, J. (1995). Developmental Trends in Visuospatial Analysis and Planning: I. Copying a Complex Figure. Neuropsychology, 9(3), 378-389. https://doi.org/10.1037/0894-4105.9.3.364

Alloway, T. P., Gathercole, S. E., \& Pickering, S. J. (2006). Verbal and visuospatial short-term and working memory in children: Are they separable? Child Development, 77(6), 1698-1716. https://doi.org/10.1111/j.14678624.2006.00968.x

Anderson, S.W., Damasio, H., Tranel, D., \& Damasio, A.R. (2000). Long-term sequelae of prefrontal cortex damage acquired in early childhood. Dev Neuropsychol. 18, 281-296. doi:10.1207/S1532694202Anderson

Anderson, P., Anderson, V., \& Garth, J. (2001). Assessment and development of organizational ability: The Rey Complex Figure Organizational Strategy Score (RCF-OSS). Clinical Neuropsychologist, 15(1), 81-94.

https://doi.org/10.1076/clin.15.1.81.1905

APA. (2017). American Psychological Association. Ethical Principles of Psychologists and Code of Conduct. American Psychologist. https://doi.org/10.1037/0003-066X.57.12.1060 
Ardila, A., Rosselli, M., Matute, E., \& Guajardo, S. (2005). The influence of the parents' educational level on the development of executive functions.

Developmental Neuropsychology, 28(1), 539-60.

https://doi.org/10.1207/s15326942dn2801_5

Arieff, A. \& Humud, C.E. (2014). Political transition in Tunisia. In: The Rise of Political Islam in North Africa. New York: Patricia Fulke Editor.

Armengol, C.G. (2002). Stroop test in Spanish: Children's norms. Clin Neuropsychol. 16(1), 67-80. https://doi.org/10.1076/clin.16.1.67.8337.

Baddeley, A. D. \& Hitch, G. J. (1994). Developments in the Concept of Working Memory. Neuropsychology, 8(4), 485-493. https://doi.org/10.1037/08944105.8.4.485

Bahous, R., Bacha, N. N. \& Nabhani, M. (2011). Multilingual educational trends and practices in Lebanon: A case study. International Review of Education, 57(5-6), 737-749. https://doi.org/10.1007/s11159-011-9250-8

Baroud, E., Alrojolah, L., Ghandour, L., Shamseddeen, W., Dirani, L. A. \& Maalouf, F. (2019a). Prevalence And Correlates Of Childhood Depression In Lebanon: Results From A National Survey. Journal of the American Academy of Child \& Adolescent Psychiatry, 58(10), 242. https://doi.org/10.1016/j.jaac.2019.08.121

Baroud, E., Ghandour, L. A., Alrojolah, L., Zeinoun, P. \& Maalouf, F. T. (2019b). Suicidality among Lebanese adolescents: Prevalence, predictors and service utilization. Psychiatry Research, 275, 338-344. https://doi.org/10.1016/j.psychres.2019.03.033

Beers, S. R. \& De Bellis, M. D. (2002). Neuropsychological function in children with maltreatment-related posttraumatic stress disorder. American Journal of Psychiatry, 159(3), 483-486. https://doi.org/10.1176/appi.ajp.159.3.483 
Bellaj, T., Salhi, I., Le Gall, D., \& Roy, A. (2016a). Development of executive functioning in school-age Tunisian children. Child Neuropsychology, 22(8), 919-954. https://doi.org/10.1080/09297049.2015.1058349

Best, J. R. \& Miller, P. H. (2010). A Developmental Perspective on Executive Function. In Child Development, 81(6), 1641-60.. https://doi.org/10.1111/j.14678624.2010.01499.x

Best, J. R., Miller, P. H., \& Jones, L. L. (2009). Executive functions after age 5. Developmental Review, 29, 180-200. https://doi.org/10.1016/j.dr.2009.05.002 T4

Bialystok, E., \& Viswanathan, M. (2009). Components of executive control with advantages for bilingual children in two cultures. Cognition, 112(3), 494-500. https://doi.org/10.1016/j.cognition.2009.06.014

Boone, K.B., Miller, B.L., Rosenberg, L., Durazo, A., McIntyre, H. \& Weil, M. (1988). Neuropsychological and behavioral abnormalities in an adolescent with frontal lobe seizures. Neurology, 38, 583-586. https://doi.org/10.1212/wnl.38.4.583

Boone, K. B., Victor, T. L., Wen, J., Razani, J., \& Pónton, M. (2007). The association between neuropsychological scores and ethnicity, language, and acculturation variables in a large patient population. Archives of Clinical Neuropsychology. $22(3): 355-365$.

Bonnier, C., Costet, A., Hmaimess, G., Catale, C., Maillart, C. \& Marique, P. (2010). Early bifrontal brain injury: Disturbances in cognitive function development. Neurol Res Int. https://doi.org/10.1155/2010/765780. 
Borsa, J. C., Damásio, B. F., \& Bandeira, D. R. (2012). Cross-cultural adaptation and validation of psychological instruments: Some considerations. Paideia, 22(53), 423-432. https://doi.org/10.1590/1982-43272253201314

Braakman, H. M. H., Vaessen, M. J., Hofman, P. A. M., Debeij-Van Hall, M. H. J. A., Backes, W. H., Vles, J. S. H., \& Aldenkamp, A. P. (2011). Cognitive and behavioral complications of frontal lobe epilepsy in children: A review of the literature. In Epilepsia, 52(5). https://doi.org/10.1111/j.1528-1167.2011.03057.x

Brickman, A.M., Cabo, R., \& Manly, J.J. (2006). Ethical issues in cross-cultural neuropsychology. Appl Neuropsychol, 13(2), 91-100. https://doi.org/10.1207/s15324826an1302_4.

Brocki, K. C., \& Bohlin, G. (2004). Executive functions in children aged 6 to 13: A dimensional and developmental study. Developmental Neuropsychology, 26(2), 571-593. https://doi.org/10.1207/s15326942dn2602_3

Buda, R. \& El Sayed-El Khouly, S. (1998). Cultural Differences Between Arabs and Americans: Individualism-Collectivism Revisited. J Cross Cult Psychol, 29(3), 487-92. doi:10.1177/0022022198293006

Byrne, B.M. \& Van de Vijver, F.J.R. (2010). Testing for measurement and structural equivalence in large-scale cross-cultural studies: Addressing the issue of nonequivalence. Int $J$ Test,10(2), 107-132. https://doi.org/10.1080/15305051003637306.

Campiglia, M., Seegmuller, C., Le Gall, D., Fournet, N., Roulin, J. L. \& Roy, A. (2014). Assessment of everyday executive functioning in children with frontal or temporal epilepsies. Epilepsy and Behavior. https://doi.org/10.1016/j.yebeh.2014.07.023 
Casey, B. J., Trainor, R. J., Orendi, J. L., Schubert, A. B., Nystrom, L. E., Giedd, J. N., Castellanos, F. X., Haxby, J. V., Noll, D. C., Cohen, J. D., Forman, S. D., Dahl, R. E. \& Rapoport, J. L. (1997). A developmental functional MRI study of prefrontal activation during performance of a Go-No-Go task. Journal of Cognitive Neuroscience, 9(6), 835-847.

https://doi.org/10.1162/jocn.1997.9.6.835

Center for Educational Research and Development. (2018). Retrieved from https://www.crdp.org/stat-details?id=26000\&la $=$ en

Chahine, M., Salameh, P., Haddad, C., Sacre, H., Soufia, M., Akel, M., Obeid, S., Hallit, R. \& Hallit, S. (2020). Suicidal ideation among Lebanese adolescents: Scale validation, prevalence and correlates. BMC Psychiatry, 20, 304. https://doi.org/10.1186/s12888-020-02726-6

Chan, R. C., Shum, D., Toulopoulou, T. \& Chen, E. Y. (2008). Assessment of executive functions: review of instruments and identification of critical issues. Arch. Clin. Neuropsychol. 23, 201-216. doi: 10.1016/j.acn.2007.08.010

Charbonnier, V., Roy, A., Seegmuller, C., Gautier, A., \& Le Gall, D. (2011). Étude d'un cas de syndrome dysexécutif à prédominance cognitive chez un enfant présentant une épilepsie frontale symptomatique. Rev Neuropsychol Neurosci Cogn Clin, 3, 11-22 . https://doi.org/10.1684/nrp.2011.0161.

Chasiotis, A., Kiessling, F., Campos, D. \& Hofer, J. (2006). Theory of mind and inhibitory control in three cultures: Conflict inhibition predicts false belief understanding in Germany, Costa Rica and Cameroon. International Journal of Behavioral Development, 30(3), 249-260. https://doi.org/10.1177/0165025406066759 
Chen, C.Y., Noble-Haeusslein, L.J., Ferriero, D. \& Semple, B.D. (2013). Traumatic injury to the immature frontal lobe: A new murine model of long-term motor impairment in the absence of psychosocial or cognitive deficits. Dev Neurosci. Published online 2013. doi:10.1159/000355874

Chieffo, D., Lettori, D., Contaldo, I., Perrino, F., Graziano, A., Palermo, C., Mittica, A., Tamburrini, G., Battaglia, D., Di Rocco, C., \& Guzzetta, F. (2011). Surgery of children with frontal lobe lesional epilepsy: Neuropsychological study. Brain and Development, 33(4), 310-315. https://doi.org/10.1016/j.braindev.2010.06.006

Chow, T. W. (2000). Personality in frontal lobe disorders. In Current psychiatry reports, 2, 446-451. https://doi.org/10.1007/s11920-000-0031-5

Claus, C.P., Tsuru-Aoyagi, K., Adwanikar, H., Walker, B., Whetstone, W., \& NobleHaeusslein, L.J. (2010). Age is a determinant of leukocyte infiltration and loss of cortical volume after traumatic brain injury. Dev Neurosci, 32, 454-465. https://doi.org/10.1159/000316805.

Culhane-Shelburne, K., Chapieski, L., Hiscock, M., \& Glaze, D. (2002). Executive functions in children with frontal and temporal lobe epilepsy. Journal of the International Neuropsychological Society, 8, 623-632.

Davidson, M. C., Amso, D., Anderson, L. C. \& Diamond, A. (2006). Development of cognitive control and executive functions from 4 to 13 years: Evidence from manipulations of memory, inhibition, and task switching. Neuropsychologia, 44(1), 2037-2078. https://doi.org/10.1016/j.neuropsychologia.2006.02.006

Dawe, S., Gullo, M. J. \& Loxton, N. J. (2004). Reward drive and rash impulsiveness as dimensions of impulsivity: implications for substance misuse. Addict. Behav. 29, 1389-1405. https://doi.org/10.1016/j.addbeh.2004.06.004 
Dennis, M. (2006). Prefrontal cortex: typical and atypical development. In: Risberg, J., Grafman, J., éds. The frontal lobes: development, function and pathology (p.128-162). New York: Cambridge University Press.

Diamond, A. (1985). Development of the ability to use recall to guide action, as indicated by infants' performance on AB. Child Development, 56(4), 868-83. https://doi.org/10.1111/j.1467-8624.1985.tb00160.x

Diamond, A. \& Goldman-Rakic, P. S. (1989). Comparison of human infants and rhesus monkeys on Piaget's AB task: evidence for dependence on dorsolateral prefrontal cortex. Experimental Brain Research, 74, 24-40. https://doi.org/10.1007/BF00248277

Diamond, A. (2013). Executive functions. In Annual Review of Psychology, 66, 114142. https://doi.org/10.1146/annurev-psych-113011-143750

Diamond, A., Zola-Morgan, S. \& Squire, L. R. (1989). Successful Performance by Monkeys With Lesions of the Hippocampal Formation on AB and Object Retrieval, Two Tasks That Mark Developmental Changes in Human Infants. Behavioral Neuroscience, 103(3), 526-537. https://doi.org/10.1037/07357044.103.3.526

El Hassan, K. (2006). Validation of the Harter Pictorial Scale of Perceived Competence and Social Acceptance with Lebanese Children. Social Behavior and Personality: An International Journal, 27(4), 339-354. https://doi.org/10.2224/sbp.1999.27.4.339

Er-Rafiqi, M., Roukoz, C., Le Gall, D., \& Roy, A. (2017b). Les fonctions exécutives chez l'enfant : développement, influences culturelles et perspectives cliniques. Revue de Neuropsychologie, 8(9), 27-34. https://doi.org/10.3917/rne.091.0027 Ferguson, C.A. (1959). Diglossia. Word, 15(2), 325-340. 
Fernández, A. L., \& Marcopulos, B. A. (2008). A comparison of normative data for the Trail Making Test from several countries: Equivalence of norms and considerations for interpretation. Scandinavian Journal of Psychology, 49, 23946.

Filippetti, V. A. (2011). Executive Functions in School-aged Children: Age and Socio-economic Status Effect. Avances En Psicologia Latinoamericana, 29(1), 98-113.

Flaks, M. K., Malta, S. M., Almeida, P. P., Bueno, O. F. A., Pupo, M. C., Andreoli, S. B., Mello, M. F., Lacerda, A. L. T., Mari, J. J., \& Bressan, R. A. (2014). Attentional and executive functions are differentially affected by post-traumatic stress disorder and trauma. Journal of Psychiatric Research, 48(1), 32-39. https://doi.org/10.1016/j.jpsychires.2013.10.009

Floden, D., Alexander, M. P., Kubu, C. S., Katz, D. \& Stuss, D. T. (2008). Impulsivity and risk-taking behavior in focal frontal lobe lesions. Neuropsychologia, 46(1), 213-223. https://doi.org/10.1016/j.neuropsychologia.2007.07.020

Frayha, N. (2009). The Negative Face of the Lebanese Education System. PDF Online. Retrieved from http://www.lebanonrenaissance.org/assets/Uploads/0The-negative-face-of-the-Lebanese-education-system-by-Nmer-Frayha-2009.pdf

Garon, N., Bryson, S. E., \& Smith, I. M. (2008). Executive Function in Preschoolers: A Review Using an Integrative Framework. Psychological Bulletin, 134(1): 3160. https://doi.org/10.1037/0033-2909.134.1.31

Gathercole, S. E., Pickering, S. J., Ambridge, B. \& Wearing, H. (2004). The Structure of Working Memory from 4 to 15 Years of Age. Developmental Psychology, 40(2), 277-190. https://doi.org/10.1037/0012-1649.40.2.177 
Grafman, J., Schwab, K., Warden, D., Pridgen, A., Brown, H. R. \& Salazar, A. M. (1996). Frontal lobe injuries, violence, and aggression: A report of the Vietnam head injury study. Neurology, 46(5), 1231-8. https://doi.org/10.1212/wnl.46.5.1231

Grattan, L.M. \& Eslinger, P.J. (1992). Long-term psychological consequences of childhood frontal lobe lesion in patient DT. Brain Cogn, 20(1), 185-195. Published online 1992. doi:10.1016/0278-2626(92)90068-W

Hernandez, M. T., Sauerwein, H. C., Jambaqué, I., De Guise, E., Lussier, F., Lortie, A., Dulac, O., \& Lassonde, M. (2002). Deficits in executive functions and motor coordination in children with frontal lobe epilepsy. Neuropsychologia, 40(4), 384-400. https://doi.org/10.1016/S0028-3932(01)00130-0

Hoff E. (2003b). The specificity of environmental influence: Socioeconomic status affects early vocabulary development via maternal speech. Child Development, 74, 1368-1378. doi: 10.1111/1467-8624.00612.

Holes, C. (2005). Dialect and national identity: The cultural politics of selfrepresentation in Bahrain musalsalaat" in Dresch, P. and Piscatori, J. (eds.) Monarchies and Nations: Globalization and Identity in the Arab States of the Gulf, Reading, I.B. Tauris, p. 52-72.

Huizinga, M., Dolan, C. V. \& Van Der Molen, M. W. (2006). Age-related change in executive function: Developmental trends and a latent variable analysis. Neuropsychologia, 44(11), 2017-36. https://doi.org/10.1016/j.neuropsychologia.2006.01.010

Imada, T., Carlson, S.M., \& Itakura, S. (2013). East-West cultural differences in context-sensitivity are evident in early childhood. Dev Sci, 16(2), 198-208. https://doi.org/10.1111/desc.12016. 
International Test Commission. (2017). ITC Guidelines for translating and adapting tests. In ITC Guidelines for Translating and Adapting Tests (Second Edition).

Itani, L., Jaalouk, D., Fayyad, J., Garcia, J. T., Chidiac, F. \& Karam, E. (2017). Mental health outcomes for war exposed children and adolescents in the Arab world. Arab Journal of Psychiatry, 28(1), 1-25. https://doi.org/10.12816/0036878

Kohen, D.E., Brooks-Gunn, J., Leventhal, T., \& Hertzman, C. (2002). Neighborhood income and physical and social disorder in Canada: Associations with young children's competencies. Child Dev., 73(6), 1844-1860. https://doi.org/10.1111/1467-8624.t01-1-00510.

Krafft, C. \& Alawode, H. (2018). Inequality of opportunity in higher education in the Middle East and North Africa. International Journal of Educucational Development, 62, 234-244. doi:10.1016/j.ijedudev.2018.05.005

Jacobsen, G. M., Prando, M. L., Moraes, A. L., Pureza, J. da R., Gonçalves, H. A., Siqueira, L. de S., Joanette, Y. \& Fonseca, R. P. (2017). Effects of age and school type on unconstrained, phonemic, and semantic verbal fluency in children. Applied Neuropsychology: Child, 6(1), 41-54.

https://doi.org/10.1080/21622965.2015.1072535

Jambaque, I. \& Dulac, O. (1989). Reversible frontal lobe syndrome and epilepsy in an 8 year-old child. Arch Fr Pediatr, 46, 525-529.

Jauregi, A., Kessler, K. \& Hassel, S. (2018). Linking cognitive measures of response inhibition and reward sensitivity to trait impulsivity. Front Psychol , 9, 2306. https://doi.org/10.3389/fpsyg.2018.02306. 
Jonkman, L. M., Lansbergen, M., \& Stauder, J. E. A. (2003). Developmental differences in behavioral and event-related brain responses associated with response preparation and inhibition in a go/nogo task. Psychophysiology, 40(5), 752-61. https://doi.org/10.1111/1469-8986.00075

Karam, E., Fayyad, J., Farhat, C., Itani, L., Mneimneh, Z., Karam, A., \& Karam, G. (2016). War and the mental health of civilians. In Disasters: Mental health context and responses.

Khalife (2006). La place de la religion à l'école. Confluences Méditerranée, 56,145160.

Klenberg, L., Korkman, M. \& Lahti-Nuuttila, P. (2001). Differential development of attention and executive functions in 3- to 12-year-old Finnish children. Developmental Neuropsychology, 20(1), 407-28. https://doi.org/10.1207/S15326942DN2001_6

Koenderink, M. J. T. \& Uylings, H. B. M. (1996). Morphometric dendritic field analysis of pyramidal neurons in the human prefrontal cortex: Relation to section thickness. Journal of Neuroscience Methods, 64, 115-122. https://doi.org/10.1016/0165-0270(95)00117-4

Lahat, A., Todd, R. M., Mahy, C. E. V., Lau, K. \& Zelazo, P. D. (2010). Neurophysiological correlates of executive function: A comparison of europeancanadian and chinese-canadian 5-year-old children. Frontiers in Human Neuroscience. https://doi.org/10.3389/neuro.09.072.2009

Lassonde, M., Sauerwein, H.C., Jambaqué, I., Smith, M., \& Helmstaedter, C. (2000). Neuropsychology of childhood epilepsy: Pre- and postsurgical assessment. Epileptic Disord. 2(1), 3-13. 
Last, B. S., Lawson, G. M., Breiner, K., Steinberg, L., \& Farah, M. J. (2018). Childhood socioeconomic status and executive function in childhood and beyond. PLoS ONE, 13(8). https://doi.org/10.1371/journal.pone.0202964

Law, N., Smith, M. L. \& Widjaja, E. (2018). Thalamocortical connections and executive function in pediatric temporal and frontal lobe epilepsy. American Journal of Neuroradiology, 39(8), 1523-1529. https://doi.org/10.3174/ajnr.A5691

Lee, K., Bull, R., \& Ho, R. M. H. (2013). Developmental changes in executive functioning. Child Development, 84(6), 1933-53. https://doi.org/10.1111/cdev.12096

Lee, N. R., Wallace, G. L., Raznahan, A., Clasen, L. S. \& Giedd, J. N. (2014). Trail making test performance in youth varies as a function of anatomical coupling between the prefrontal cortex and distributed cortical regions. Frontiers in Psychology, 5, 496. https://doi.org/10.3389/fpsyg.2014.00496

Lehto, J. E., Juujärvi, P., Kooistra, L. \& Pulkkinen, L. (2003). Dimensions of executive functioning: Evidence from children. British Journal of Developmental Psychology, 21(1), 59-80. https://doi.org/10.1348/026151003321164627

Levin, H. S. \& Hanten, G. (2005). Executive functions after traumatic brain injury in children. In Pediatric Neurology, 33(2), 79-93.. https://doi.org/10.1016/j.pediatrneurol.2005.02.002

Levy, B.J., McVeigh, N.D., Marful, A., \& Anderson, M.C. (2007). Inhibiting Your Native Language. Psychol Sci., 18(1), 29-34. https://doi.org/10.1111/j.14679280.2007.01844.x.

Lipina, S. J. \& Evers, K. (2017). Neuroscience of childhood poverty: Evidence of impacts and mechanisms as vehicles of dialog with ethics. Frontiers in 
Psychology, 8,61. https://doi.org/10.3389/fpsyg.2017.00061

Loewenstein, D.A., Arguelles, T., Arguelles, S., \& Linn-Fuentes, P. (1994). Potential cultural bias in the neuropsychological assessment of the older adult. Journal of Clinical and Experimental Neuropsychology, 16, 623-629

Lorena, J., Richard, M., Andres, M. \& Introzzi, I. (2013). Development Patterns of Executive Functions in Children. The Spanish Journal of Psychology, 16(41).

Luciana, M., Conklin, H. M., Hooper, C. J. \& Yarger, R. S. (2005). The development of nonverbal working memory processes in adolescence: different maturational trajectories for recall versus executive control. Child Development, 76(3), 697712. https://doi.org/10.1111/j.1467-8624.2005.00872.x

Luciana, M. \& Nelson, C. A. (1998). The functional emergence of prefrontally-guided working memory systems in four- to eight-year-old children. Neuropsychologia, 36(3), 273-93. https://doi.org/10.1016/S0028-3932(97)00109-7

Luna, B., Garver, K. E., Urban, T. A., Lazar, N. A. \& Sweeney, J. A. (2004). Maturation of cognitive processes from late childhood to adulthood. Child Development, 75(5), 1357-72.. https://doi.org/10.1111/j.1467-8624.2004.00745.x

Maalouf, F. T., Ghandour, L. A., Halabi, F., Zeinoun, P., Shehab, A. A. S. \& Tavitian, L. (2016). Psychiatric disorders among adolescents from Lebanon: prevalence, correlates, and treatment gap. Social Psychiatry and Psychiatric Epidemiology, 51(8), 1105-1116. https://doi.org/10.1007/s00127-016-1241-4

MacKillop, J., Weafer, J., Gray, J. C., Oshri, A., Palmer, A. \& De Wit, H. (2016). The latent structure of impulsivity: impulsive choice, impulsive action, and impulsive personality traits. Psychopharmacology, 233, 3361-3370. 10.1007/s00213-016$4372-0$. 
MacLeod, C. M. (1992). The Stroop task: The "gold standard" of attentional measures. Journal of Experimental Psychology: General, 121(1). https://doi.org/10.1037/0096-3445.121.1.12

Makki, M. (2007). The French Language in Lebanon: Language of Division or Consensus? Herodote, 126(3), 161-167.

Malarbi, S., Abu-Rayya, H. M., Muscara, F. \& Stargatt, R. (2017). Neuropsychological functioning of childhood trauma and post-traumatic stress disorder: A meta-analysis. In Neuroscience and Biobehavioral Reviews, 72, 6886. https://doi.org/10.1016/j.neubiorev.2016.11.004

Martens, R., Hurks, P. P. \& Jolles, J. (2014). Organizational strategy use in children aged 5-7: standardization and validity of the Rey Complex Figure Organizational Strategy Score (RCF-OSS). The Clinical Neuropsychologist, 28(6), 1-20. https://doi.org/10.1080/13854046.2014.939228

Matar Touma, V. \& Moussallem, Y. (2016). La nécessité de l'adaptation d'un test cognitif à la culture arabe-le cas du WISC-IV. Pratiques Psychologiques, 22(1), 75-85. https://doi.org/10.1016/j.prps.2015.09.001

McDermott, L. M. \& Ebmeier, K. P. (2009). A meta-analysis of depression severity and cognitive function. In Journal of Affective Disorders, 119(1-3), 1-8. . https://doi.org/10.1016/j.jad.2009.04.022

Miller, E. K. \& Cohen, J. D. (2001). An integrative theory of prefrontal cortex function. In Annual Review of Neuroscience, 24, 167-202. https://doi.org/10.1146/annurev.neuro.24.1.167

Mikati, A.G., Abu Gheida, I., Shamseddine, A., Mikati, M.A., \& Karam P.E. (2013). Epileptic and electroencephalographic manifestations of guanidinoacetatemethyltransferase deficiency. Epileptic Disord,15, 407-416. 
Miranda, A., Colomer, C., Mercader, J., Fernandez, I. \& Presentacion, J. (2015). Performance-based tests versus behavioral ratings in the assessment of executive functioning in preschoolers: associations with ADHD symptoms and reading achievement. Front. Psychol.,6, 545. doi: 10.3389/fpsyg.2015.00545.

Mischel, W. \& Ebbesen, E. B. (1970). Attention in delay of gratification. Journal of Personality and Social Psychology, 16(2), 329-337. https://doi.org/10.1037/h0029815

Miyake, A., Friedman, N. P., Emerson, M. J., Witzki, A. H., Howerter, A. \& Wager, T. D. (2000). The Unity and Diversity of Executive Functions and their Contributions to Complex "Frontal Lobe" Tasks: A Latent Variable Analysis. Cognitive Psychology, 41(1), 49-100. https://doi.org/10.1006/cogp.1999.0734

Noble, K. G., Houston, S. M., Brito, N. H., Bartsch, H., Kan, E., Kuperman, J. M., Akshoomoff, N., Amaral, D. G., Bloss, C. S., Libiger, O., Schork, N. J., Murray, S. S., Casey, B. J., Chang, L., Ernst, T. M., Frazier, J. A., Gruen, J. R., Kennedy, D. N., Van Zijl, P., ... Sowell, E. R. (2015). Family income, parental education and brain structure in children and adolescents. Nature Neuroscience, 18(5), 773-778. https://doi.org/10.1038/nn.3983

Olff, M., Polak, A.R., Witteveen, A.B. \& Denys D. (2014). Executive function in posttraumatic stress disorder (PTSD) and the influence of comorbid depression. Neurobiol Learn Mem, 112, 114-121. https://doi.org/10.1016/j.nlm.2014.01.003.

Owens, M., Stevenson, J., Hadwin, J. A. \& Norgate, R. (2012). Anxiety and depression in academic performance: An exploration of the mediating factors of worry and working memory. School Psychology International, 33(4), 433-449. https://doi.org/10.1177/0143034311427433 
Piaget, J. (1964). Part I: Cognitive development in children: Piaget development and learning. Journal of Research in Science Teaching, 2(3), 176-186. https://doi.org/10.1002/tea.3660020306

PNUD report (2009). Lebanon toward a citizen state, p. 132.

Price, B.H., Daffner, K.R., Stowe, R.M. \& Mesulam, M.M. (1990). The comportmental learning disabilities of early frontal lobe damage. Brain, 113(5), 1383-1393. doi:10.1093/brain/113.5.1383

Riccio, C. A., Pliego, J. A., Cohen, M. J., \& Park, Y. (2015). Executive Function Performance for Children With Epilepsy Localized to the Frontal or Temporal Lobes. Applied Neuropsychology: Child, 4(4), 277-284. https://doi.org/10.1080/21622965.2014.923774

Richa, S., Rohayem, J., Chammai, R., Kazour, F., Haddad, R., Hleis, S., Alameddine, A. \& Gerbaka, B. (2014). ADHD Prevalence in Lebanese School-Age Population. Journal of Attention Disorders 18(3), 242-6. https://doi.org/10.1177/1087054712445065

Risse, G. L. (2006). Cognitive outcomes in patients with frontal lobe epilepsy. Epilepsia, 47(2), 87-89. https://doi.org/10.1111/j.1528-1167.2006.00699.x

Riva, D., Avanzini, G., Franceschetti, S., Nichelli, F., Saletti, V., Vago, C., Pantaleoni, C., D’Arrigo, S., Andreucci, E., Aggio, F., Paruta, N., \& Bulgheroni, S. (2005). Unilateral frontal lobe epilepsy affects executive functions in children. Neurological Sciences, 26, 263-270. https://doi.org/10.1007/s10072-005-0469-7

Rivera Mindt, M., Arentoft, A., Kubo Germano, K., D’Aquila, E., Scheiner, D., Pizzirusso, M., Sandoval, T. C., \& Gollan, T. H. (2008). Neuropsychological, cognitive, and theoretical considerations for evaluation of bilingual individuals. In Neuropsychology Review, 18(3), 255-68. https://doi.org/10.1007/s11065-008- 
9069-7

Rosselli, M. \& Ardila, A. (2003). The impact of culture and education on non-verbal neuropsychological measurements: A critical review. Brain and Cognition, 52(3), 326-33. https://doi.org/10.1016/S0278-2626(03)00170-2

Röthlisberger, M., Neuenschwander, R., Cimeli, P. \& Roebers, C. M. (2013). Executive Functions in 5- to 8-Year Olds: Developmental Changes and Relationship to Academic Achievement. Journal of Educational and Developmental Psychology, 3(2). https://doi.org/10.5539/jedp.v3n2p153

Roukoz, C., Er Rafiqi, M., Le Gall, D., Bellaj, T. \& Roy, A. (2018). A Systematic Review of Cross-cultural Studies on Executive Functions in Children. International Journal of Psychology and Neuroscience, 4(3), 1-31,

Roy, A., Le Gall, D., Roulin, J-L. \& Fournet, N. (2012). Les fonctions exécutives chez l'enfant: approche épistémologique et sémiologie clinique. Revue de Neuropsychologie, Neurosciences Cognitives et Cliniques, 4, 287-297. https://doi.org/10.1684/nrp.2012.0242

Roy, A., Fournet, N., Le Gall, D. \& Roulin, J.-L. (2013). Adaptation et validation en français de l'inventaire comportemental d'évaluation des fonctions exécutives (BRIEF: Behavior Rating Inventory of Executive Function). Paris : Hogrefe.

Sabbagh, M. A., Xu, F., Carlson, S. M., Moses, L. J. \& Lee, K. (2006). The development of executive functioning and theory of mind: A comparison of Chinese and U.S. preschoolers. Psychological Science 17(1), 74-81. https://doi.org/10.1111/j.1467-9280.2005.01667.x

Sarsour, K., Sheridan, M., Jutte, D., Nuru-Jeter, A., Hinshaw, S. \& Boyce, W. T. (2011). Family socioeconomic status and child executive functions: The roles of language, home environment, and single parenthood. Journal of the International 
Neuropsychological Society, 17, 120-132.

https://doi.org/10.1017/S1355617710001335

Saunders, B., Milyavskaya, M., Etz, A., Randles, T. \& Inzlich. M. (2018). Reported Self-control is not Meaningfully Associated with Inhibition-related Executive Function: A Bayesian Analysis. Collabra: Psychology, 4(1), 39. doi: https://doi.org/10.1525/collabra.134

Scott, J.C., Matt, G.E., Wrocklage, K.M., Crnich, C., Jordan, J., Southwick, S.M., Krystal, J.H. \& Schweinsburg, B.C. (2015) Quantitative meta-analysis of neurocognitive functioning in posttraumatic stress disorder. Psychol Bull 141(1), 105-140. https://doi.org/10.1037/a0038039.

Sesma, H. W., Slomine, B. S., Ding, R., \& McCarthy, M. L. (2008). Executive functioning in the first year after pediatric traumatic brain injury. Pediatrics, 121(6), 1686-95. https://doi.org/10.1542/peds.2007-2461

Shaaban, K. \& Ghaith, G. (1997). An integrated approach to foreign language learning in lebanon. Language, Culture and Curriculum, 10(3), 200-207. https://doi.org/10.1080/07908319709525252

Shawish, H. (2010, June 24). Campaign to save the Arabic language in Lebanon. BBC News. Retrieved from http://www.bbc.com/news/10316914.

Sheppard, K. W. \& Cheatham, C. L. (2017). Validating the Electric Maze Task as a Measure of Planning. Journal of Cognition and Development, 18(2), 309-322. https://doi.org/10.1080/15248372.2016.1195387

Soueid, M., Ghanem, S., Hariri, Z., Yamout, N., \& Nehme, R. (2014). Analysis of Lebanon's Education Sector. BankMed Market \& Economic Research Division. [updated Nov 10; cited 2015 Apr 6]. Available from:

http://www.bankmed.com.lb/ 
Swann, A. C. (2010). Mechanisms of impulsivity in bipolar disorder and related illness. Epidemiol. Psichiatr. Soc., 19, 120-130.

Thorell, L. B., Veleiro, A., Siu, A. F. Y., \& Mohammadi, H. (2013). Examining the relation between ratings of executive functioning and academic achievement: Findings from a cross-cultural study.Child Neuropsychology, 19(6), 630-638. https://doi.org/10.1080/09297049.2012. 727792

Toplak, E., West, R. \& Stanovich, K. (2013). Practitioner Review: Do performancebased_measures and ratings of executive function assess the same construct? Journal of Child Psychology and Psychiatry, 54(2), 131-143. doi:10.1111/jcpp.12001

Tranel, D. \& Eslinger, P.J. (2000). Effects of early onset brain injury on the development of cognition and behavior: Introduction to the special issue. Dev Neuropsychol 18(3), 273-280. https://doi.org/10.1207/S1532694201Tranel. Tsuru-Aoyagi, K., Potts, M.B., Trivedi, A., Pfankuch, T., Raber, J., Wendland, M., Claus, C.P., Koh, S.E., Ferriero, D., \& Noble-Haeusslein, L.J. (2009):

Glutathione peroxidase activity modulates recovery in the injured immature brain. Ann Neurol, 65, 540-549.

Van de Vijver, F. J. R., \& Leung, K. (1997). Cross-cultural psychology series, Vol. 1.Methods and data analysis for cross-cultural research. Sage Publications, Inc. Welsh, M., Pennington, B., \& Groisser, D. (1991) A normative-developmental study of executive function: A window on prefrontal function in children, Developmental Neuropsychology, 7(2), 131149, doi: $\underline{10.1080 / 87565649109540483}$ 
Wilson, D.M. \& Gross, D. (2018). Parents' Executive Functioning and Involvement in Their Child's Education: An Integrated Literature Review. J Sch Health, 88(4). https://doi.org/10.1111/josh.12612.

Zeinoun, P., Farran, N., Khoury, S. J. \& Darwish, H. (2020). Development, Psychometric Properties and Pilot Norms of the First Arabic Indigenous Memory Test: The Verbal Memory Arabic Test (VMAT). Journal of Clinical and Experimental Neuropsychology, 42(5), 505-515.

https://doi.org/10.1080/13803395.2020.1773408

Zelazo, P. D., Muller, U., Frye, D. \& Marcovitch, S. (2003). VI. The Development of Executive Function: Cognitive Complexity and Control-Revised. Monographs of the Society for Research in Child Development, 68(3), 93-119.

https://doi.org/10.1111/j.0037-976x.2003.00266.x 


\section{ANNEXES}




\section{ANNEXE 1}

Roukoz Cynthia | Développement des Fonctions Exécutives chez les Enfants 


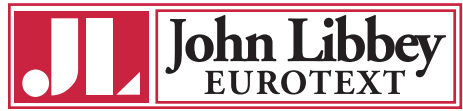

L'essentiel de l'information scientifique et médicale

$\underline{\text { www.jle.com }}$

\section{Le sommaire de ce numéro}

http://www.john-libbey-eurotext.fr/fr/ revues $/$ medecine/nrp/sommaire.md?type $=$ text.html

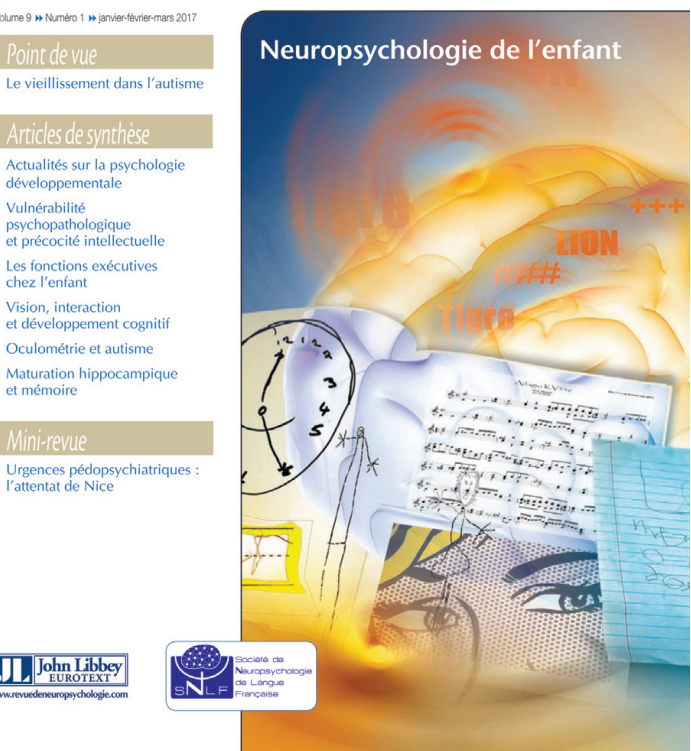

\section{Montrouge, le 09-03-2017}

Marie Er-Rafiqi

Vous trouverez ci-après le tiré à part de votre article au format électronique (pdf) :

Les fonctions exécutives chez l'enfant : développement, influences culturelles et perspectives cliniques

\section{paru dans}

Revue de neuropsychologie, 2017, Volume 9, Numéro 1

\section{John Libbey Eurotext}

Ce tiré à part numérique vous est délivré pour votre propre usage et ne peut être transmis à des tiers qu'à des fins de recherches personnelles ou scientifiques. En aucun cas, il ne doit faire l'objet d'une distribution ou d'une utilisation promotionnelle, commerciale ou publicitaire. Tous droits de reproduction, d'adaptation, de traduction et de diffusion réservés pour tous pays. 
Article de synthèse

Rev Neuropsychol

$2017 ; 9$ (1) : 27-34

\section{Les fonctions exécutives chez l'enfant: développement, influences culturelles et perspectives cliniques}

\section{Executive functions in children: development, cultural influences and clinical perspectives}

Marie Er-Rafiqi ${ }^{1}$, Cynthia Roukoz ${ }^{2}$, Didier Le Gall ${ }^{3}$, Arnaud Roy ${ }^{4}$

${ }^{1}$ Laboratoire de psychologie des Pays de la Loire, Université Bretagne-Loire,

Université d'Angers, 11, boulevard Lavoisier, 49045 Angers, France

<marie.errafiqi@gmail.com>

2 Psychological Assessment Center,

Psychiatry Department,

American University of Beirut Medical Center Hamra, Beirut, Liban

${ }^{3} \mathrm{CHU}$ d'Angers, Département de Neurologie, Unité de neuropsychologie,

49100 Angers, France

${ }^{4} \mathrm{CHU}$ de Nantes, Hôpital Femme-EnfantAdolescent, Centre référent des troubles d'apprentissage et Centre de compétence nantais de neurofibromatose, 44000 Nantes, France

Pour citer cet article : Er-Rafiqi $M$, Roukoz C, Le Gall D, Roy A. Les fonction exécutives chez l'enfant: développement, influences culturelles et perspectives cliniques. Rev Neuropsychol 2017 ; 9 (1) : 27 34 doi:10.1684/nrp.2017.0405

\section{Résumé} nières années, leur étude a suscité un intérêt majeur dans le champ de la neuropsychologie de l'enfant, plus particulièrement depuis l'accumulation d'arguments empiriques suggérant un lien potentiel entre les perturbations exécutives et les difficultés d'ordre cognitif, scolaire et psychosocial. Aujourd'hui, nombreuses sont les données qui montrent que les habiletés exécutives se développent précocement et de façon prolongée. Cette idée est reprise dans une proposition théorique récente formulée par Diamond (2013), qui détaille les principales FE à travers un modèle intégratif à composantes multiples. Néanmoins, ce type de modèle ne prévoit pas l'effet de l'environnement et de la culture sur le développement des FE, alors que plusieurs arguments existent désormais et sont en faveur d'une influence potentielle de ces dimensions. Dans cet article, une synthèse des principales données empiriques accumulées dans ce domaine est proposée, ainsi qu'une réflexion sur les enjeux cliniques liés à la prise en compte indispensable de la culture en cas de perturbation du développement cérébral. Plusieurs éléments de prospective sont proposés, en particulier d'ordre méthodologique, afin de favoriser l'émergence d'outils d'évaluation neuropsychologique des FE adaptés à l'enfant, qui prennent en compte a minima l'effet de l'environnement et du contexte culturel.

Mots clés : fonctions exécutives • développement $\cdot$ culture $\cdot$ variables sociodémographiques

Abstract

Since the emerging evidence of the role of Executive Functions (EFS) on children's cognitive, academic and psychosocial functioning, EFs have generated growing interest in the field of child neuropsychology. Studies of EF among children are relatively new and limited theoretical frameworks of EF in children are available to date. Diamond (2013) presents a competing model supporting a multicomponent structure of EF in the first years of life. Diamond (2013) supports a non-linear non-synchronous progression of core EF. However, neither Diamond's model, nor other models available to date, take into consideration the potential influence of one's environment on EF development, even though recent studies suggest that the developmental curve of EF is subject to be influenced by culture and sociodemographic variables. Lack of appropriate cultural norms poses a challenge to the assessment of EFs across cultures and increases the likelihood of diagnostic errors due to cultural biases. This paper will elaborate on recent knowledge on the development of EF in children. In a second section, an overview of existing studies discussing potential influences 
of cultural and sociodemographic variables such as gender, language proficiency, type of education, parent's education level, and culture, will be presented. In a third and last part, guidelines on how to improve clinical evaluation of EF among children from different cultures will be discussed.

Key words: executive functions $\cdot$ development $\cdot$ culture $\cdot$ sociodemographic variables

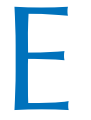
n neuropsychologie, il est communément admis que les fonctions exécutives (FE) regroupent un ensemble $\mathrm{d}^{\prime}$ habiletés de haut niveau nécessaires à la réalisation d'un comportement dirigé vers un but [1,2]. Elles ont pour fonction de faciliter l'adaptation aux situations nouvelles. Ces processus interviennent notamment dans la régulation du comportement ou dans la prise de décision. Les FE sont sollicitées lorsque les routines d'action ou les habiletés cognitives automatiques ne sont pas suffisantes et que I'usage de processus contrôlés, dits top-down, est requis [3]. En outre, plusieurs arguments empiriques accumulés ces dernières années favorisent l'idée selon laquelle les FE entretiennent des liens étroits avec la santé mentale et physique, la réussite scolaire et professionnelle, et plus globalement avec le développement social, cognitif et psychologique [4].

Chez l'enfant, il y a désormais de nombreuses données qui démontrent que les processus exécutifs se développent de manière à la fois très précoce et prolongée, ce qui illustre une dynamique développementale coïncidant avec le rythme particulier de maturation du cortex préfrontal [5]. En revanche, l'effet de l'environnement sur l'émergence des FE a jusqu'à présent été moins étudié, alors que le contexte sociodémographique et culturel dans lequel I'enfant vient au monde et grandit, influence potentiellement de manière déterminante la mise en place de ces habiletés. En conséquence, les FE - par définition - contribuent au maintien de I'homéostasie en regard du contexte. De ce fait, elles engagent la question de leur hétérogénéité en lien avec l'expérience personnelle et la culture. Paradoxalement, les modèles théoriques proposés dans le domaine des FE chez l'enfant ne prévoient pas l'effet de I'environnement et de la culture, ce qui interroge la valence universelle de ces modèles et par conséquent, leur généralisation d'un contexte à l'autre.

Dans cet article de synthèse, nous revenons dans une première partie sur les grandes caractéristiques des principales FE classiquement distinguées dans les modélisations théoriques actuelles en neuropsychologie de l'enfant, à travers le modèle intégratif récemment proposé par Diamond [4]. Nous insistons en particulier sur l'ordre chronologique d'apparition des processus exécutifs chez l'enfant, tel que proposé par Diamond, incluant l'inhibition, la mémoire de travail, la flexibilité et la planification. Dans une seconde partie, nous présentons plusieurs données empiriques supportant l'idée qu'il est essentiel de considérer la culture au cœur du développement des FE. Par ailleurs, nous exposons la façon dont les variables sociodémographiques, telles que le genre ou le niveau d'éducation des parents, sont susceptibles de jouer un rôle déterminant dans le développement cognitif. Dans une troisième et dernière partie, nous verrons que si les modèles théoriques ne prévoient pas l'effet de l'environnement, les outils disponibles dans le cadre de l'évaluation des FE sont aussi utilisés sans prendre en considération la culture, ce qui n'est pas sans interroger la pertinence de la démarche clinique. Dans ce contexte et à travers cette revue de la littérature, nous mettons en avant la nécessité de faire évoluer les outils psychométriques existants par des adaptations spécifiques à l'environnement, afin que l'évaluation et les stratégies d'examen des dysfonctionnements exécutifs - et donc leur prise en charge - soit plus fiable et adaptée aux particularités de l'environnement dans lequel l'enfant grandit.

\section{Les fonctions exécutives, modèles actuels et développement}

Tant chez l'adulte que chez l'enfant, I'hypothèse de FE plurielles mais interdépendantes prévaut dans la littérature, à l'instar des études factorielles qui distinguent généralement le contrôle inhibiteur, la mémoire de travail ou la mise à jour, et la flexibilité cognitive [6,7]. Ces processus sont caractérisés par un développement prolongé en lien avec la maturation particulièrement longue du cortex préfrontal, principal siège biologique des FE. En raison du développement caudo-rostral du cerveau, l'élimination synaptique et la myélinisation des régions préfrontales sont plus tardives par rapport aux autres régions cérébrales et se prolongent ainsi jusqu'au début de l'âge adulte. Aujourd'hui, plusieurs données empiriques soutiennent ainsi l'idée d'une maturité ontogénétique tardive des FE. Les performances au test classique de Stroop illustrent bien cette idée pour le contrôle inhibiteur, avec des courbes développementales très prolongées dans le temps [8]. Pour autant, ce développement prolongé ne doit pas masquer l'émergence précoce et essentielle des FE dès les premiers mois de vie du bébé. L'accomplissement du paradigme A-non-B de Piaget [9] est aujourd'hui interprété comme étant l'une des premières manifestations de l'émergence des FE chez le nourrisson. Pour que le bébé puisse réussir l'épreuve A-non-B, il doit pouvoir maintenir en mémoire l'endroit où est cachée la récompense tout en inhibant la réponse précédemment donnée. À l'appui de cette idée, Diamond [10] a montré des corrélations anatomofonctionnelles entre la réussite de 


\section{Article de synthèse}

l'épreuve par les bébés et l'activation précoce des régions dorsolatérales du cortex préfrontal.

Chez l'enfant, Diamond [4] a récemment établi un modèle théorique intégratif du développement des FE, incluant les trois principaux processus cités ci-dessus, ainsi que les habiletés de planification et de résolution de problèmes, considérées par l'auteure comme des «fonctions exécutives de plus haut niveau ». Le contrôle inhibiteur est la capacité à contrôler son attention, son comportement, ses pensées et/ou ses émotions, afin de surmonter les tentations internes et externes. Sont ainsi distinguées l'inhibition comportementale de l'inhibition cognitive. Toutes deux permettent progressivement à l'enfant d'ajuster son comportement, afin qu'il soit adapté aux différentes situations de la vie courante. Par opposition, l'impulsivité correspond à I'incapacité de l'enfant à autoréguler et/ou à différer ses réactions. Sur le plan scolaire, les capacités d'inhibition permettent à l'enfant de se focaliser sur son travail ou encore d'ignorer les distractions. L'inhibition cognitive permet de supprimer les représentations mentales inadéquates, afin, par exemple, d'ignorer ou d'effacer certains souvenirs ou des pensées non désirées. Enfin, l'inhibition permet également de soulager la mémoire de travail en supprimant les stimuli superflus.

La mémoire de travail est définie comme étant la capacité à mémoriser et manipuler des informations sur une période de temps limitée [11]. De nature verbale et non verbale, elle permet à l'enfant de maintenir temporairement en mémoire un ensemble d'informations et de coordonner plusieurs tâches. Elle est nécessaire pour faire le lien entre plusieurs éléments dans le but de les assembler en un tout global ou au contraire pour permettre de les dissocier afin de les organiser de manière différente. La mémoire de travail apparaît comme un processus indispensable à l'organisation spatiale et temporelle. Elle favorise le développement cognitif et les apprentissages tels que le langage oral (e.g., développement du lexique et compréhension), la lecture et l'écriture (notamment l'adressage et l'assemblage), le calcul et les résolutions de problème, ou encore la mémoire à long terme (e.g., effet de récence). D'après Diamond [4], sans le soutien de la mémoire de travail, les capacités de raisonnement cognitif seraient perturbées. Enfin, plusieurs données s'appuyant sur l'évaluation de la boucle phonologique et du calepin visuospatial montrent d'importants progrès en mémoire de travail pendant I'enfance $[12,13]$.

$\mathrm{S}^{\prime}$ il est désormais relativement bien établi que les capacités de mémoire de travail et d'inhibition observent toutes deux un développement à la fois précoce et prolongé, aucun consensus n'a été trouvé quant à l'ordre d'apparition de ces deux FE [4, 14]. Elles sont supposées entretenir une relation $d^{\prime}$ interdépendance; par exemple, maintenir des informations en mémoire est essentiel pour identifier les éléments superflus à inhiber. Réciproquement, inhiber les distractions en provenance de l'environnement et/ou les pensées incongrues est déterminant pour rester concentré sur les éléments stockés en mémoire de travail [4]. Si
I'un de ces deux processus est défaillant, le second le sera potentiellement.

La flexibilité cognitive se construit à partir du socle formé par l'inhibition cognitive et la mémoire de travail : elle serait ainsi tributaire du développement de ces deux processus et émergerait donc plus tardivement au cours de I'enfance [4]. La flexibilité cognitive se définit comme la capacité de changer rapidement de tâches (alterner entre différentes tâches ou différentes consignes) ou de stratégie et d'analyser l'environnement selon différentes perspectives. Pour que la flexibilité cognitive puisse émerger, I'enfant doit être capable d'inhiber certains stimuli internes ou externes afin d'orienter son attention vers $d^{\prime}$ autres perspectives stockées en mémoire de travail. Par exemple, lors d'un exercice de mathématique, si la première hypothèse formulée pour résoudre un problème s'avère fausse, il faut être capable de l'inhiber et d'en formuler une autre. Diamond suggère également que la flexibilité mentale est le support de la créativité et de la théorie de l'esprit [4]. D'un point de vue empirique, certains travaux ont montré l'émergence précoce d'une certaine flexibilité, puisqu'à partir de deux ans et demi, les enfants sont capables de réussir des tâches dans lesquelles ils doivent inverser des consignes simples [15]. De la même façon, Frye et al. ont proposé une épreuve plus complexe (le Dimensional Change Card Sort Test - DCCST) et ont observé une transition en termes de performance entre l'âge de 3 ans, où l'enfant est en échec parce qu'il commet des erreurs de persévération, et l'âge de 4 ans, où il réussit l'épreuve [16]. La progression des capacités de flexibilité se poursuit pendant l'enfance, comme l'ont montré par exemple des travaux chez des enfants plus âgés à l'aide de tâches de fluence verbale [17].

La planification, le raisonnement et la résolution de problème sont considérés par Diamond comme des processus exécutifs de plus haut niveau [4]. Ils incluent la capacité à formuler des hypothèses à partir d'éléments abstraits ou concrets, ou encore la capacité à organiser ses pensées. Ils permettent à l'enfant d'établir et d'initier des plans d'actions, de formuler des stratégies ou encore d'organiser les étapes nécessaires pour atteindre un objectif précis. Une atteinte de ces habiletés est susceptible d'entraîner des perturbations sévères du fonctionnement cognitif, et d'affecter potentiellement l'ensemble des fonctions supérieures. Sur le plan scolaire, les aptitudes de planification permettent d'anticiper et de structurer le travail ou les jeux, de ranger son matériel, par exemple son espace de travail ou son cartable, et plus généralement, d'organiser ses apprentissages. La tour de Hanoï est une épreuve classiquement utilisée pour évaluer les performances en planification; elle a notamment été employée dans les premières études empiriques consacrées au développement exécutif. À partir d'une version simplifiée de l'épreuve, il a ainsi été montré que les performances augmentaient avec l'âge, avec des pics développementaux entre 5 et 6 ans [18]. Le développement de ces processus de planification serait tributaire du socle formé par la mémoire de travail, l'inhibition et la flexibilité mentale, expliquant par conséquent leur émergence 
plus tardive [4]. Cette hypothèse coïncide avec les observations neurophysiologiques étayant l'idée d'une maturation cérébrale prolongée jusqu'à l'âge adulte.

Le modèle intégratif de Diamond propose ainsi une structure hiérarchisée spécifique au développement des habiletés exécutives [4]. II offre une large conceptualisation des FE, structurée en modules interdépendants et interactifs, sur la base des données empiriques accumulées ces dernières années et des principes néo-piagétiens. Le développement des FE est considéré comme un processus précoce, prolongé et différencié selon l'âge des enfants, donnant lieu à différents calendriers développementaux. Dans ce contexte, l'effet potentiel des facteurs sociodémographiques - et plus largement de la culture - sur le développement exécutif constitue une réflexion centrale, puisqu'elle interroge la valence universelle de ce type de modélisation théorique et, de fait, sa généralisation d'un contexte à l'autre. Paradoxalement, l'étude de ces variables reste à ce jour limitée et n'est même pas envisagée dans le cadre des propositions théoriques actuelles, à l'instar du modèle de Diamond [4].

\section{Influence des variables culturelles et sociodémographiques}

Durant ces dix dernières années, plusieurs études ont été consacrées à l'effet du contexte sur le développement des FE. À partir de comparaisons inter et intra culturelles, certaines d'entre-elles ont mis en évidence une influence des facteurs sociodémographiques tels que le genre ou le bilinguisme, et plus largement, un effet de la culture, sur le développement des FE. Cette partie propose donc de détailler certaines de ces études, afin de mieux comprendre comment se développent les FE en interaction avec l'appartenance culturelle et les caractéristiques sociodémographiques d'un enfant.

S'agissant des variables sociodémographiques, plusieurs études ont montré l'influence de telles variables sur le développement des FE. En d'autres termes, des enfants appartenant à une même culture présenteraient des différences de fonctionnement exécutif, selon le genre, le niveau d'éducation des parents, les compétences langagières ou plus globalement le statut socioéconomique de la famille. Ces facteurs sont également susceptibles d'interagir avec la culture dans la mesure où l'influence des variables sociodémographiques sur les FE serait différente en fonction de la culture de l'individu.

Le genre de l'enfant a été étudié à plusieurs reprises comme une variable susceptible d'avoir un rôle sur le développement des FE. Certaines études ont ainsi relevé des différences significatives en faveur des filles [e.g., 19], d'autres en faveur des garçons [e.g., 20], et d'autres encore n'ont pas trouvé d'effet statistiquement significatif de ce facteur [e.g., 7]. Récemment, Bellaj et al. [17] ont par exemple constaté de meilleures performances chez les garçons tunisiens d'âge scolaire dans une mesure de mémoire de travail visuo-spatiale, mais aucune autre différence significative n'a été retrouvée pour les diverses autres mesures des FE. Selon certains travaux, l'effet du genre pourrait interagir avec la culture. Ismatullina et al. [21] ont par exemple observé que les garçons kirghizes d'Asie centrale obtenaient de meilleures performances que les filles à une tâche de mémoire de travail visuo-spatiale, tandis que le contraire était observé chez des enfants russes. Les chercheurs en ont conclu que l'influence du genre sur les capacités de mémoire de travail pourrait être culture-dépendante, dans la mesure où cette influence serait différente en fonction de la culture de l'enfant. En revanche, les auteurs n'ont pas proposé d'hypothèse pour tenter d'expliquer - d'un point de vue culturel ou sociologique - ces résultats. Ce type d'interaction a été retrouvé dans d'autres cultures, comme I'illustre une étude récente de Thorell et al. [22]. Dans leur recherche, les auteurs ont observé un effet significatif du genre en faveur des garçons iraniens (par comparaison avec les filles), à partir d'un questionnaire (à destination des parents) évaluant les FE dans la vie quotidienne ; l'effet inverse, cette fois en défaveur des garçons, était constaté chez les enfants suédois, espagnols et chinois. L'effet $d^{\prime}$ interaction entre genre et culture dans cette dernière étude était interprété comme susceptible de refléter le statut - différent - de la femme dans ces cultures. L'hypothèse explicative envisagée spécifiait que le statut particulier de la femme en Iran, considéré comme «inférieur » à celui de I'homme, tend à amener les parents iraniens à sousestimer les capacités de leurs filles, en leur attribuant plus de difficultés exécutives au quotidien [22].

Le bilinguisme aurait également une influence sur le développement des FE. Les études présentées dans ce paragraphe utilisent la même définition du bilinguisme, à savoir l'exposition à deux langues dès la naissance. Bialystok et Viswanathan [23] ont ainsi par exemple évalué les capacités $d^{\prime}$ inhibition et de flexibilité mentale auprès d'enfants canadiens et indiens d'âge scolaire, monolingues et bilingues, et ont montré un effet significatif du bilinguisme, indépendamment de la culture, sur le développement des FE : les enfants bilingues canadiens et indiens montraient de meilleures performances au niveau des tâches d'inhibition et de flexibilité mentale que leurs homologues monolingues. De même, Carlson et Meltzoff [24] ont comparé trois groupes d'enfants américains en s'intéressant à différentes compétences langagières : le premier groupe était bilingue et exposé à deux langues dès la naissance, le deuxième groupe était monolingue, et le troisième groupe était monolingue mais intégré dans une école qui enseignait une deuxième langue. Les enfants bilingues avaient de meilleures performances aux tâches de FE que les deux autres groupes. Crivello et al. [25] ont aussi conclu à un effet positif du bilinguisme sur le développement exécutif en comparant des enfants canadiens bilingues, exposés au français et à l'anglais depuis la naissance, à des enfants américains monolingues, exposés uniquement à l'anglais. Ils ont pu démontrer un lien significatif entre le 
vocabulaire connu dans les deux langues et les compétences exécutives : le nombre de mots qu'un enfant connaît dans deux langues différentes affecterait positivement ses aptitudes exécutives, et plus spécifiquement dans cette étude, ses capacités d'inhibition. Ce bénéfice pourrait être dû au fait que lorsqu'un individu bilingue fournit un mot dans une langue donnée, le mot équivalent dans I'autre langue serait systématiquement activé puis inhibé, favorisant ainsi le développement du contrôle inhibiteur.

D'autres variables sociodémographiques, telles que le niveau d'éducation des parents ou le type d'école fréquentée par l'enfant, auraient également un effet sur le développement des FE, même si aucun consensus n'est encore établi à ce jour. Par exemple, il n'a pas été retrouvé, chez les enfants tunisiens d'âge scolaire, d'effet du niveau d'éducation des parents sur le fonctionnement exécutif des enfants, à l'exception d'un effet du niveau d'éducation du père sur certaines mesures, comme le temps d'exécution d'une tâche d'inhibition ou l'empan de chiffres envers [17]. En revanche, une autre étude réalisée auprès d'un groupe d'enfants américains d'âge scolaire a démontré un effet robuste du type d'école fréquentée (privée versus publique) et un effet variable du niveau d'éducation des parents sur les performances à des tâches censées évaluer différents aspects des FE tels que la génération d'idées et la conceptualisation verbale et non verbale, la flexibilité mentale ou encore la résolution de problèmes [19].

S'agissant de l'effet de la culture sur le développement des FE, plusieurs travaux empiriques ont également été réalisés. Les cultures les plus étudiées sont les cultures chinoises et américaines. Par exemple, Sabbagh et al. [26] ont comparé des enfants chinois et américains et ont mis en évidence de «meilleures » performances des enfants chinois aux tâches évaluant l'inhibition, la flexibilité mentale et l'impulsivité. De manière similaire, Lan et al. [27] ont comparé des enfants chinois et américains en utilisant des tâches mesurant leurs performances en mémoire de travail, inhibition et contrôle attentionnel. Ils ont observé de meilleures performances chez les enfants chinois aux tâches d'inhibition et de contrôle attentionnel. Ces différences de performances s'expliqueraient - selon les auteurs - à la fois par des facteurs socioculturels, et par une prédisposition génétique $[26,27]$. L'une des hypothèses proposée pour expliquer ces différences de performances tiendrait au fait que les parents et les enseignants chinois valoriseraient le contrôle inhibiteur chez les enfants dès le plus jeune âge, correspondant à la période préscolaire. Ainsi, la discipline de l'enfant, sa capacité à suivre les instructions et à se concentrer sur une période prolongée (sur un même support) seraient toutes des exigences précoces dans la culture chinoise [27]. Ces différences de performances ont également été attribuées à des facteurs génétiques, au sens où la répétition du gène $D R D 4$ de l'allèle 7 (associé à un risqué plus élevé de trouble déficitaire de l'attention avec ou sans hyperactivité - TDA/H - et donc à un dysfonctionnement exécutif) serait plus commune dans les populations américaines [28].
S'il est vrai que la culture est susceptible d'influencer le développement exécutif, une variabilité entre les études est à signaler. Un des facteurs proposé pour l'expliquer est la différence dans le choix des outils d'évaluation des FE, qui peuvent conduire à des résultats partiellement contradictoires. Par exemple, Thorell et al. [22] ont trouvé des différences au niveau du fonctionnement exécutif chez des enfants issus de différentes cultures, en défaveur des enfants chinois (i.e., comparés avec des enfants de Suède, d'Iran ou d'Espagne), par contraste avec plusieurs travaux présentés précédemment $[26,27]$. Cette apparente contradiction avec les études précédentes peut néanmoins s'expliquer par les stratégies d'évaluation respectivement engagées: Thorell et al. ont utilisé des questionnaires comportementaux visant à apprécier les FE dans la vie quotidienne, plutôt que des tests évaluant la performance des enfants. Ce choix d'outils pourrait être à l'origine de biais culturels expliquant les résultats observés. En effet, les capacités d'autorégulation étant plus valorisées par les parents chinois, ces derniers auront tendance à juger et évaluer plus sévèrement leurs enfants sur cette dimension.

En l'état actuel des données disponibles dans la littérature, il apparaît donc que les FE sont probablement en étroite interaction avec le contexte culturel et sociodémographique dans lequel un enfant naît et grandit. L'influence complexe du contexte explique sans doute au moins en partie pourquoi il est difficile, à ce jour, de dresser un calendrier développemental précis des FE au cours de l'enfance. Si les travaux transculturels demeurent encore limités, le fait que la majorité d'entre eux soient en faveur d'un effet significatif de la culture sur le développement exécutif justifie d'approfondir les connaissances dans ce domaine. Ces seules données pourraient contribuer à expliquer la variabilité de l'expression développementale ainsi que la difficulté - et le manque de pertinence - à penser une modélisation universelle des FE.

\section{Préconisations et perspectives cliniques}

Au regard des travaux empiriques qui viennent d'être évoqués, il apparaît aujourd'hui essentiel de poursuivre les recherches concernant l'influence des variables culturelles et sociodémographiques sur le développement des FE chez l'enfant, compte tenu des enjeux théoriques et cliniques associés à une telle démarche. Les chercheurs et les cliniciens doivent donc redoubler de prudence s'ils envisagent d'étudier ces dimensions, en particulier s'ils utilisent des épreuves a priori similaires d'un pays à l'autre. Bien qu'un test soit employé dans une même langue, par exemple en France et en Belgique, il n'en reste pas moins qu'il existe deux cultures sous-jacentes bien différentes et donc deux populations disposant de leurs propres particularités biopsychosociales. C'est ce qu'ont dévoilé Fernandez et Marcopulos [29] dans une étude réalisée avec des sujets âgés de 15 à 83 ans dans dix pays différents. Les auteurs ont montré que les différences constatées en termes de 


\section{Article de synthèse}

données normatives sont si importantes, qu'un même individu peut obtenir des performances déficitaires si ses résultats sont analysés avec les normes d'un pays voisin. Ils ont ainsi mis en évidence le danger que représente l'utilisation d'un même test (associée à une norme unique) d'un pays à l'autre. D'après Bellaj et Le Gall [30], cette différence de performance doit absolument être évaluée sous un angle culturel, autrement dit en tenant compte de I'ensemble des facteurs explicatifs liés au contexte.

Un des enjeux cliniques de cette synthèse vise à montrer comment la validité d'un outil utilisé à travers le monde dépend de la culture dans laquelle il s'inscrit. Prenons l'exemple du test classique de Stroop, qui consiste à inhiber le processus automatique de la lecture. Dans cette tâche, on présente à l'enfant des noms de couleur écrits avec une encre dont la couleur ne correspond pas, le sujet ayant pour consigne de nommer la couleur de l'encre. Il lui faut donc inhiber la lecture du mot. Par exemple, si le mot vert est écrit en rouge, le sujet doit inhiber le mot «vert » et répondre «rouge». Le calcul du nombre d'erreurs et la mesure du temps de réalisation de cette tâche sont censés refléter les performances en inhibition. Admettons maintenant que nous voulions utiliser cette épreuve dans une autre culture que la nôtre. Pour ce type d'épreuve, nous pouvons penser qu'il n'y a pas grande différence entre, par exemple, la population française et la population marocaine. Or la langue est différente et elle constitue une source majeure de biais. En effet, pour le mot « rouge», un Marocain dira «al-ahmar » qui correspond à un temps de prononciation plus long que celui attendu pour le même mot en français. Cette différence de temps peut paraître minime de prime abord (et elle l'est dans l'absolu), mais elle apparaîtra potentiellement significative lorsque nous voudrons comparer la vitesse globale de l'enfant marocain par rapport à l'enfant français à l'issue de cette épreuve (qui dure généralement plusieurs minutes). Une conclusion hâtive pourrait nous faire dire que les performances de l'enfant français sont meilleures que celles de son homologue marocain alors qu'elles sont en réalité la conséquence probable d'un biais culturel, qui n'a rien à voir avec l'aptitude exécutive recherchée à travers la tâche psychométrique elle-même. Hormis cette différence de performance liée au langage, nous pouvons aussi admettre que la version française de l'épreuve serait inadaptée à la population marocaine si nous voulions I'utiliser telle quelle. En effet, le sens de lecture doit être orienté de la droite vers la gauche pour que le test puisse être proposé dans les pays arabophones. Ces différences culturelles en apparence anodines peuvent être la cause de nombreux biais susceptibles d'être retrouvés dans certaines études.

Par ailleurs, il faut également être prudent quant à l'usage d'épreuves non verbales dont on pourrait penser qu'elles peuvent s'utiliser d'un pays à l'autre sans adaptation particulière, sous prétexte que le test s'affranchit a priori du langage. Une épreuve, qu'elle soit verbale ou non verbale, sera nécessairement imprégnée de la culture dans laquelle elle a été créée. Nous pouvons prendre
I'exemple de la figure de Rey. La croyance veut qu'elle soit adaptée à toutes les cultures dans la mesure où elle est « uniquement » composée d'éléments géométriques juxtaposés. Or, si l'on examine plus attentivement cette figure, on s'aperçoit qu'elle est pour la majeure partie constituée d'angles droits, de lignes droites et de figures géométriques simples. Si cette figure paraît convenir à la culture occidentale, elle ne l'est en revanche pas forcément pour le monde oriental, qui fait intrinsèquement appel à des motifs beaucoup plus ondulants et arqués. Nous pouvons alors imaginer qu'un enfant libanais, par exemple, rencontrera plus de difficultés à planifier la copie de la figure de Rey par rapport à un enfant suisse, dans la mesure où il est moins habitué, dans son bain culturel, à des motifs de ce type.

Ces éléments tendent à interroger notre propre pratique clinique de l'évaluation neuropsychologique. En effet, quel matériel pouvons-nous employer lorsque se présente un patient d'origine étrangère? Quelles normes utiliser pour l'évaluation d'un enfant issu de plusieurs cultures différentes ou «simplement» bilingue? Comment distinguer la réelle pathologie des performances amoindries par les contraintes culturelles? Bellaj et Seron [31] proposent cinq solutions pratiques pour répondre à ces questions. Les deux premières consistent soit à (1) utiliser les mêmes tests et normes quelle que soit la culture, soit à (2) utiliser les mêmes tests mais à partir de normes adaptées à la culture. Ces deux premières propositions sont les moins fiables et présentent des risques de biais importants. En conséquence, elles sont à employer en dernier recours, d'autant plus chez I'enfant compte tenu de la dynamique développementale complexe qui caractérise cette population. Les solutions les plus élaborées consistent à réaliser (3) une traduction et une normalisation du test ou d'en proposer (4) une adaptation. Enfin, la cinquième et meilleure solution reste (5) la création d'un test original propre à la culture évaluée.

Dans le sillon du projet $\mathrm{FEE}^{1}$, plusieurs études sont actuellement engagées de manière conjointe en Tunisie, au Liban, au Maroc et au Brésil, avec pour objectif d'évaluer le développement des FE des enfants dans une perspective transculturelle. Ces recherches affichent plusieurs objectifs théoriques et cliniques complémentaires. Le premier consiste à développer et disposer d'outils standards comparables d'une culture à l'autre (donc adaptés d'une culture à l'autre, avec des normes appropriées) afin d'améliorer la fiabilité des stratégies d'examen. Pour ce faire, la traduction et I'adaptation des épreuves et des questionnaires du protocole FEE ont été appliquées en respectant les procédures conseillées par Bellaj et Seron [31]. Ces dernières ont suivi une méthode nommée Translation and back-translation composée de deux étapes principales. La première consiste en une traduction des épreuves et de leurs consignes par des experts chercheurs, neuropsychologues et/ou linguistes [31]. Une analyse du matériel par, au minimum, deux

1 Fonctions exécutives de l'enfant ; Roy, Fournet, Le Gall, Roulin, en cours ; voir Roy, 2015, pour une description. 
experts ainsi que des études pilotes sont ensuite pratiquées constituant des étapes indispensables pour évaluer la fiabilité de la traduction. La seconde étape, effectuée par deux autres experts, consiste à réaliser une traduction inverse, dont le résultat final doit correspondre aux consignes initiales de la langue source, assurant ainsi l'invariabilité du test. Ce premier objectif vise donc à obtenir une meilleure sensibilité et spécificité des outils d'évaluation neuropsychologique en adaptant culturellement chaque instrument. Comme cela a été mentionné plus haut, évaluer un enfant sans prendre en compte ses particularités culturelles et sociodémographiques pourrait mener à des biais importants. Par exemple, la notion du temps peut constituer un biais sociocognitif dans l'évaluation neuropsychologique. Un grand nombre de tests évalue la performance en fonction du temps de complétion de la tâche alors qu'il a été démontré que l'attitude d'un individu vis-à-vis des tests de vitesse serait culturellement déterminé [31]. De plus, la notion même d'un déficit neurocognitif serait culturellement déterminée étant donné qu'elle dépend des attentes que la société place en chaque individu [31]. Ainsi, afin d'éviter des résultats biaisés, menant, par exemple, à passer à côté d'un trouble (faux négatif) ou au contraire, à considérer comme déficitaire une fonction qui ne l'est pas (faux positif), il est primordial de prendre en compte le contexte culturel de l'enfant qui est évalué et d'adapter les outils en conséquence.

Le second objectif des études transculturelles engagées autour du projet FEE est de favoriser une meilleure compréhension des déterminants développementaux des FE en repositionnant la culture au centre de la recherche et en interrogeant ainsi les modélisations théoriques actuelles. Chez l'enfant, le modèle intégratif à composants multiples proposé par Adèle Diamond ne prévoit pas explicitement, en effet, le rôle joué par l'environnement et la culture dans le développement des différentes facettes des FE. II s'agit donc d'examiner de manière plus systématique, et à travers différentes cultures dans le monde, les arguments empiriques susceptibles d'apporter une réponse plus précise à cette question. Cette problématique est d'autant plus importante que plusieurs travaux montrent l'existence potentielle $d^{\prime}$ un lien entre développement des FE et cognition sociale, intelligence, ou encore réussite scolaire et professionnelle [5].

Enfin, ces travaux ont pour troisième objectif fondamental de rechercher les invariants cliniques du syndrome dysexécutif d'une culture à l'autre, autrement dit les caractéristiques «universelles» des troubles des FE dans la population pédiatrique. Le caractère précoce et prolongé du développement des FE est un facteur de risque pour des perturbations exécutives persistantes jusqu'à l'âge adulte [32], d'autant plus que les FE sont en lien étroit avec la mise en place des aptitudes académiques [22], de la théorie de l'esprit [26], et plus globalement le comportement [27]. Les dysfonctionnements exécutifs chez l'enfant vont par conséquent potentiellement induire des difficultés durables et susceptibles de s'aggraver avec le temps (apparition « différée » des troubles), compte tenu de l'augmentation avec l'âge des exigences d'indépendance et de développement des compétences sociales et académiques. De ce fait, s'il est important d'adapter des outils visant l'ensemble des fonctions cognitives des enfants dans une culture donnée, l'évaluation des FE reste une priorité en neuropsychologie, d'autant plus que de très nombreux contextes cliniques sont concernés. En effet, des perturbations précoces des FE sont avérées ou suspectées dans diverses pathologies neurodéveloppementales et acquises tels que le TDA/H, le trouble du spectre autistique, les maladies génétiques, les troubles spécifiques d'apprentissage, l'épilepsie, le traumatisme crânien, ou encore les tumeurs cérébrales. Cette fragilité est en lien avec la vulnérabilité précoce des réseaux frontosous-corticaux chez l'enfant, de par leur développement prolongé durant l'enfance [32].

\section{Conclusion}

S'il est désormais largement admis que les FE occupent une place centrale dans le développement psychologique et qu'elles sont particulièrement vulnérables en cas d'anomalie cérébrale chez l'enfant, I'influence précise du contexte sociodémographique et culturel reste paradoxalement méconnue. Les données empiriques accumulées ces dernières années tendent à favoriser l'idée que ces variables inhérentes à l'individu et à la société dans laquelle il naît et grandit, telles que le genre, le niveau d'éducation parentale, le bilinguisme, ou encore la culture, sont probablement déterminantes dans la mise en place et la structuration des FE dès le plus jeune âge. Bien que l'effet de ces variables nécessite d'être consolidé et précisé de manière à la fois plus large, plus nuancée et plus systématique à travers le monde, les résultats préliminaires dans ce domaine incitent à favoriser une vision davantage cosmopolite des déterminants du développement et de la structure des FE chez I'enfant. Les implications cliniques d'une telle démarche sont fondamentales pour la neuropsychologie de l'enfant et I'accompagnement des jeunes patients, puisqu'il s'agit également d'interroger la manière dont les dysfonctionnements exécutifs surviennent et se manifestent, dépendamment et indépendamment du contexte dans lequel ils surviennent.

\section{Liens d'intérêts}

les auteurs déclarent ne pas avoir de lien d'intérêt en rapport avec cet article. 


\section{Références}

1. Luria AR. Higher cortical functions in man. New York: Basic Books, 1966.

2. Stuss DT, Benson DF. The frontal lobes. New York: Raven Press, 1986.

3. Seron $X$, van der Linden $M$, Andrès $P$. Le lobe frontal : à la recherche de ses spécificités fonctionnelles. In : van der Linden M, Seron X, Le Gall D, Andrès P, éds. Neuropsychologie des lobes frontaux. Marseille: Solal, 1999, p. 33-88.

4. Diamond A. Executive functions. Annu Rev Psychol 2013;64: 135-68.

5. Roy A. Les fonctions exécutives chez l'enfant : des considérations développementales et cliniques à la réalité scolaire. Dev 2015; 7 : 13-40.

6. Miyake A, Friedman NP, Emerson MJ, et al. The unity and diversity of executive functions and their contributions to complex "frontal lobe" tasks: a latent variable analysis. Cognit Psychol 2000;41:49-100.

7. Brocki KC, Bohlin G. Executive functions in children aged 6 to 13: a dimensional and developmental study. Dev Neuropsychol $2004 ; 26: 571-93$.

8. Roy A, Kefi MZ, Bellaj T, et al. The Stroop test: a developmental study in a french children sample aged 7 to 12 years. Psychol Fr 2016 (Version on line : http://dx.doi.org/10.1016/j.psfr.2016.08.001).

9. Piaget J. La naissance de l'intelligence chez l'enfant. Neuchâtel: Delachaux \& Niestlé, 1936.

10. Diamond A. De l'intention à l'action: le cortex préfrontal et le développement cognitif précoce. In : Metz-Lutz MN, Demont E, Seegmuller C, et al, éds. Développement cognitif et troubles des apprentissages. Marseille: Solal, 2004, p. 13-35.

11. Baddeley A. Working memory: theories, models, and controversies. Annu Rev Psychol $2012 ; 63: 1-29$.

12. Baddeley A. Working memory. Oxford: Clarendon Press, 1986. 13. Alloway TP, Gathercole SE, Pickering SJ. Verbal and visuospatial short-term and working memory in children: are they separable? Child Dev $2006 ; 77: 1698-716$.

14. Dennis M. Prefrontal cortex: typical and atypical development. In : Risberg J, Grafman J, éds. The frontal lobes: development, function and pathology. New York: Cambridge University Press, 2006, p. 128-62. 15. Brooks P, Hanauer JB, Padowska B, et al. The role of selective attention in preschoolers' rule use in a novel dimensional card sort. Cognit Dev $2003 ; 117: 1-21$.

16. Frye D, Zelazo PD, Pafai T. Theory of mind and rule-based reasoning. Cognit Dev 1995; 10:483-527.

17. Bellaj T, Salhi I, Le Gall D, et al. Development of executive functioning in school-age Tunisian children. Child Neuropsychol $2015 ; 22: 919-54$.
18. Welsh MC. Rule-guided behavior and self-monitoring on the Tower of Hanoi disk-transfer task. Cognit Dev 1991; 6:59-76.

19. Ardila A, Rosselli $M$, Matute $E$, et al. The influence of the parents'educational level on the development of executive functions. Dev Neuropsychol $2005 ; 28: 539-60$.

20. Halpern DF. Sex differences in cognitive abilities, 3rd ed.. Mahwah: Lawrence Erlbaum Associates, 2000.

21. Ismatullina V, Voronin I, Shelemetieva A, et al. Cross-cultural study of working memory in adolescents. Proc Soc Behav Sci $2014 ; 146: 353-7$.

22. Thorell LB, Veleiro A, Siu AF, et al. Examining the relation between ratings of executive functioning and academic achievement: findings from a cross-cultural study. Child Neuropsychol $2013 ; 19: 630-8$.

23. Bialystok $E$, Viswanathan $M$. Components of executive control with advantages for bilingual children in two cultures. Cogn $2009 ; 112: 494-500$.

24. Carlson SM, Meltzoff A. Bilingual experience and executive functioning in young children. Dev Sci 2008; 11 : 282-98.

25. Crivello C, Kuzyk O, Rodrigues M, et al. The effects of bilingual growth on toddlers' executive function. I Exp Child Psychol $2016 ; 141: 121-32$.

26. Sabbagh MA, Xu F, Carlson SM, et al. The development of executive functioning and theory of mind. A comparison of Chinese and U.S. preschoolers. Psychol Sci 2006; 17 : 74-81.

27. Lan X, Legare $\mathrm{CH}$, Ponitz CC, et al. Investigating the links between the subcomponents of executive function and academic achievement: A cross- cultural analysis of Chinese and American preschoolers. J Exp Child Psychol 2011; 108:677-92.

28. Chang F-M, Kidd JR, Kivak KJ, et al. The world-wide distribution of allele frequencies at the human dopamine D4 receptor locus. Hum Genet 1996;98:91-101.

29. Fernández AL, Marcopulos BA. A comparison of normative data for the trail making test from several countries: equivalence of norms and considerations for interpretation. Scand J Psychol 2008; 49 : 239-46.

30. Bellaj T, Le Gall D. L'évaluation neuropsychologique dans le contexte du Maghreb. In : Amieva $\mathrm{H}$, Belin C, Maillet D, éds. L'évaluation neuropsychologique De la norme à l'exception. Bruxelles: De Boeck supérieur, 2016, p. 165-90.

31. Bellaj T, Seron X. Les facteurs culturels dans l'évaluation neuropsychologique. In : Seron $X$, van der Linden $M$, éds. Traité de neuropsychologie clinique de l'adulte, 2ème édition. Marseille: De Boeck-Solal, 2014, p. 641-58.

32. Roy A, Le Gall D, Roulin JL, et al. Les fonctions exécutives chez l'enfant : approche épistémologique et sémiologie clinique. Neuropsychol Rev 2012; 4 : 287-97. 


\section{ANNEXE 2}

Roukoz Cynthia | Développement des Fonctions Exécutives chez les Enfants 


\title{
Chapitre 13 Fonctions exécutives, environnement et contexte chez l'enfant
}

\author{
Marie Er Rafiqi ${ }^{1,2,3}$, Cynthia Roukoz ${ }^{1,4}$, \\ Didier Le Gall ${ }^{1,5}$ et Arnaud Roy ${ }^{1,6}$ \\ ${ }^{1}$ Laboratoire de psychologie des Pays de la Loire, \\ EA4638, université d'Angers, France \\ ${ }^{2}$ Service d'éducation spéciale et de soins à domicile "Mille Sabords", \\ Centre hospitalier Guillaume-Régnier Rennes, France \\ ${ }^{3}$ Pôle de compétences et de prestations externalisées, \\ Adapei 53, Laval, France \\ ${ }^{4}$ American university of Beirut medical center, \\ Psychiatry department, Liban \\ ${ }^{5}$ Unité de neuropsychologie, Département de neurologie, \\ CHU d'Angers, France \\ ${ }^{6}$ Centre référent des troubles d'apprentissage \\ et Centre de compétence nantais de neurofibromatose, \\ Hôpital Femme-Enfant-Adolescent, CHU de Nantes, France
}

\section{Introduction}

Depuis une trentaine d'années, les connaissances relatives au développement typique et perturbé des fonctions exécutives (FE) chez l'enfant ont connu un essor considérable, qui a contribué à favoriser un intérêt croissant des professionnels de l'éducation et de la santé pour ce champ thématique. Il est désormais largement admis que les habiletés regroupées derrière ce terme jouent un rôle déterminant dans le développement psychologique de l'enfant, que ce soit pour la mise en place des apprentissages, l'autorégulation 
du comportement ou encore l'acquisition des compétences sociales (Diamond, 2013). Processus de contrôle dits « de haut niveau », les FE permettent à l'individu de s'adapter aux différents contextes de vie quotidienne et d'organiser ses actions en fonction d'un objectif précis (Luria, 1966 ; Miyake et al., 2000).

Par contraste avec l'adulte, ces capacités d'adaptation sont immatures et en plein développement chez l'enfant, en lien avec la maturation physiologique précoce mais prolongée des circuits fronto-sous-corticaux du cerveau. Cette particularité développementale a conduit ces dernières années à envisager plusieurs modélisations théoriques susceptibles de rendre compte de la mise en place des FE au décours de l'enfance. De par leur positionnement central dans l'architecture cognitive, la sollicitation des processus exécutifs est engagée dès lors que l'enfant doit apprendre à adapter son comportement en fonction des différents contextes environnementaux auxquels il est confronté. La prise en compte de cette dimension contextuelle conduit inévitablement à interroger la place et l'influence des facteurs inhérents à l'environnement dans lequel l'enfant grandit et plus globalement sa culture d'appartenance.

Ce questionnement est déterminant pour l'approche neuropsychologique des troubles des FE chez l'enfant, dont on sait qu'ils surviennent dans différents contextes cliniques en pédiatrie, et dont l'évaluation devrait dans l'idéal pouvoir tenir compte. Nous proposons dans ce chapitre de revenir sur ces aspects, dans le prolongement des travaux précédemment publiés par notre équipe sur cette question (en particulier : Er-Rafiqi et al., 2017; Roy et al., 2017). Dans une première partie, nous rappelons les principales étapes clés du développement des $\mathrm{FE}$ et leur modélisation avant de nous attarder, dans une deuxième partie, sur quelques données actuelles qui témoignent de l'importance potentielle de la culture et du contexte pour mieux appréhender le développement des FE. Nous poursuivrons par un bref exposé des enjeux liés à l'évaluation de ces processus chez l'enfant, en tenant compte de ces éléments contextuels/culturels, et en mettant en lumière la complémentarité des épreuves basées sur la performance et celles relevant de l'approche dite « écologique». Enfin, une brève synthèse de la symptomatologie caractéristique du syndrome dysexécutif chez l'enfant sera proposée, en lien avec la notion de vulnérabilité précoce.

\section{Le développement des fonctions exécutives chez l'enfant}

\subsection{Définitions}

À l'instar des conceptualisations en neuropsychologie de l'adulte, les FE sont des termes employés chez l'enfant pour désigner l'ensemble des habiletés cognitives de haut niveau permettant la réalisation d'un comportement dirigé vers un but (Luria, 1966). Ces processus de contrôle sont dits «top-down » puisqu'ils vont permettre, à partir de nos connaissances, de nous adapter aux différents contextes et d'être en 
mesure, par exemple, d'organiser nos actions. Ces capacités d'adaptation sont indispensables notamment lorsque nous sommes face à des situations nouvelles et que les automatismes ou les routines ne suffisent plus. Les FE occupent ainsi une place centrale dans la supervision du comportement (Seron et al., 1999).

Certains auteurs différencient les FE selon la situation dans laquelle elles sont mobilisées (Zelazo \& Müller, 2002). Les contextes sollicitant de manière préférentielle le raisonnement logique, sans état émotionnel particulier, renvoient au versant froid aussi appelé registre cold ou cool, comme lorsque l'enfant doit préparer/organiser son cartable pour l'école. Cette composante cold regroupe habituellement différents processus tels que la planification et la résolution de problèmes, l'inhibition, la flexibilité mentale, ou encore les capacités de mémoire de travail. Par ailleurs, la prise d'initiative ou le monitoring (exemple : vérifier son travail) sont également associés aux FE (Gioia et al., 2000). La nature des processus exécutifs et leur niveau d'interaction font encore débat parmi les chercheurs. Par exemple, certains auteurs considèrent que la vitesse de traitement constitue un processus exécutif à part entière et donc indépendant alors que pour d'autres elle sous-tendrait la variance partagée entre les FE (Lee et al., 2013).

Lorsque la situation implique principalement des enjeux affectifs, émotionnels et/ou motivationnels, comme dans le cas où l'enfant doit faire preuve d'empathie envers ses camarades, on parle de fonctionnement exécutif chaud ou de registre hot (Bechara et al., 2000). Cette composante englobe les capacités de prise de décision affective déterminées par l'analyse du contexte (exemple : évaluation du risque en cas de danger) et les capacités d'autorégulation et de contrôle émotionnel, étroitement rattachées aux habiletés sociales et à l'ajustement de son propre comportement selon les situations.

\subsection{Maturation cérébrale, développement et structure des fonctions exécutives}

Les enjeux scientifiques que représente l'étude des FE transparaissent dans les particularités développementales qui caractérisent les régions préfrontales et leurs réseaux, sièges biologiques principaux supposés des FE. La maturation caudo-rostrale du cerveau (de la partie postérieure vers la partie antérieure) se traduit en effet par une élimination synaptique et une myélinisation plus tardives des régions préfrontales, phénomène qui pourrait expliquer la maturité ontogénétique tardive des FE autour de 25 ans. Ce rythme particulier de développement ne signifie pas pour autant que l'émergence des habiletés de contrôle exécutif n'est pas précoce, puisque leur mise en œuvre dynamique dès les premiers mois de la vie a été mise en évidence (Roy et al., 2012).

S’agissant de la structure des FE, les modélisations théoriques actuelles, et notamment les recherches basées sur les analyses factorielles réalisées chez l'enfant, soutiennent une approche modulaire comme chez l'adulte, avec cependant une 
différenciation progressive de chaque processus exécutif avec l'âge. De 2 à 5 ans (âge préscolaire), les modèles unitaires prévalent, proposant ainsi une indifférenciation pendant cette période (Lee et al., 2013), alors que les recherches factorielles réalisées chez l'enfant plus âgé favorisent l'idée de processus exécutifs partiellement indépendants et modulaires (Lehto et al., 2003). La différenciation des processus exécutifs telle qu'elle est conçue chez l'adulte débuterait vers 5-6 ans (coïncidant avec la période scolaire) : les FE commenceraient à cette période à s'individualiser tout en restant relativement interdépendantes.

Les données actuelles favorisent l'idée selon laquelle les capacités d'inhibition et de mémoire de travail sont les premières à se différencier et constituent le socle nécessaire au développement des habiletés de flexibilité mentale (Dennis, 2006 ; Diamond, 2013), qui se différencient à leur tour au cours de l'adolescence. Ce n'est que plus tardivement, chez le jeune adulte, que les compétences en termes de planification, de résolution de problèmes ou encore d'abstraction deviendraient plus indépendantes. Comme évoqué précédemment, la place précise de certains processus, tels que la vitesse de traitement, et les calendriers développementaux qui les caractérisent restent aujourd'hui en partie controversés (Lee et al., 2013).

Par contraste avec ces modélisations théoriques de plus en plus précises du développement et de la structure des FE chez l'enfant, la question du contexte et de la culture au sens large n'est à aucun moment envisagée, y compris dans les propositions les plus récentes (Dennis, 2006 ; Diamond, 2013 ; Lee et al., 2013).

\section{Le développement exécutif et le contexte}

Les recherches empiriques de ces 10 dernières années consacrées à l'étude de l'effet du contexte sur le développement des FE ont montré une probable influence de différents facteurs sociodémographiques et culturels sur l'émergence et le développement des processus exécutifs.

\subsection{Quid des facteurs sociodémographiques (intraculturels) ?}

Le genre, le niveau d'éducation parentale, les habiletés langagières ou de manière plus globale le statut socio-économique de la famille seraient des facteurs influençant le fonctionnement exécutif (Berlin \& Bohlin, 2002 ; Hoff, 2003 ; Pena et al., 2002). Ces variables auraient un impact sur le développement exécutif au sein d'une même culture mais également en interaction avec cette dernière. Autrement dit, l'influence de ces facteurs serait différente selon le pays dans lequel elle s'exerce (Ismatullina et al., 2014).

Une des variables sociodémographiques les plus étudiées dans la littérature est le genre, bien que les données scientifiques accumulées jusqu'à présent n'aient pas permis de trouver de consensus. Si certaines études n'ont pas trouvé d'effet 
statistiquement significatif du genre sur le développement exécutif (Brocki \& Bohlin, 2004), d'autres ont montré des différences significatives en faveur des garçons (Halpern, 2000) ou des filles (Ardila et al., 2005). Si l'on y regarde néanmoins de plus près, l'effet du genre semble très variable d'une tâche à l'autre y compris au sein d'une même recherche (Ardila et al., 2005). Une étude conduite récemment a, par exemple, montré que les garçons tunisiens d'âge scolaire obtenaient de meilleures performances dans une tâche de mémoire de travail visuo-spatiale mais qu'aucune différence significative n'était relevée pour les autres tâches proposées (Bellaj et al., 2015). Il est intéressant de constater que d'autres travaux ont également montré de meilleures performances à une tâche de mémoire de travail visuo-spatiale chez les garçons kirghizes (Asie centrale) tandis que l'effet inverse était constaté pour cette même tâche réalisée avec des enfants russes (Ismatullina et al., 2014). L’influence du genre sur le développement des FE serait donc à la fois variable selon les mesures utilisées mais aussi en fonction du pays et de la culture d'appartenance.

Bien que ce type d'interaction soit montré dans plusieurs études, peu d'hypothèses explicatives d'ordre sociologique ou culturel ont été fournies pour expliquer ces données. C'est le cas d'une étude récente (Thorell et al., 2013) qui a montré un effet d'interaction entre le genre et la culture sur le développement des FE, à partir de questionnaires de vie quotidienne relatifs aux FE remplis par les parents. Alors que des difficultés supérieures ont été identifiées chez les garçons suédois, espagnols et chinois (par rapport aux filles), le phénomène inverse a été observé en Iran, où les petites filles faisaient l'objet de plaintes accrues en regard des garçons de la même culture. L'une des hypothèses envisagées tiendrait au statut particulier de la femme dans chacune de ces cultures : dans certaines régions de l'Iran, les parents auraient tendance à sous-estimer les capacités de leur fille et leur attribueraient plus de difficultés exécutives du fait du statut de l'homme, considéré comme « supérieur » à celui de la femme.

Parmi les autres variables susceptibles d'influencer le développement exécutif, les capacités langagières particulières qui sont mobilisées via le bilinguisme sont importantes à considérer. Le bilinguisme est défini comme étant l'exposition de l'individu à deux langues dès les premiers jours de la vie. Crivello et al. (2016) ont ainsi relevé un effet significatif du bilinguisme sur le fonctionnement exécutif en montrant que les enfants canadiens bilingues (français et anglais) présentaient de meilleures performances de contrôle inhibiteur que celles d'enfants américains monolingues (ne parlant que l'anglais). Cette supériorité de l'inhibition chez l'enfant bilingue est supposée être liée au fait que ce dernier est contraint d'inhiber les mots homologues lorsqu'il parle avec l'une des deux langues, l'obligeant ainsi, contrairement à l'enfant monolingue, à solliciter plus systématiquement le contrôle inhibiteur. De même, l'étude de Bialystok et Viswanathan (2009) a montré un effet significatif du bilinguisme sur le développement des FE en comparant des enfants indiens et canadiens d'âge scolaire, monolingues et bilingues. Les enfants monolingues issus des deux cultures ont ainsi obtenu de moins bonnes performances dans des tâches d'inhibition et de flexibilité mentale par rapport aux enfants bilingues. D'autres auteurs ont 
également constaté un effet positif du bilinguisme sur le fonctionnement exécutif des enfants américains (Carlson \& Meltzoff, 2008), en montrant que les enfants bilingues et exposés à deux langues dès la naissance obtenaient de meilleures performances aux épreuves exécutives que les enfants monolingues (y compris ceux qui suivaient des cours dans une école dispensant une seconde langue).

Les données disponibles dans la littérature suggèrent enfin une influence probable du niveau d'éducation parentale ou du type d'école fréquenté selon la culture (exemple : privée versus publique) sur le fonctionnement exécutif et son développement (Berlin \& Bohlin, 2002 ; Hoff, 2003 ; Pena et al., 2002). En revanche, aucun consensus n'émerge quant à l'influence de ces variables sociodémographiques. Par exemple, une recherche conduite avec des enfants américains d'âge scolaire a montré des effets des deux facteurs évoqués ci-dessus sur les performances à des tâches évaluant certains aspects des FE telles que la flexibilité cognitive, la conceptualisation verbale et non verbale ou encore la résolution de problème (Ardila et al., 2005). D'autres travaux n'ont pas montré d'influence significative du niveau d'étude des parents, par exemple, chez les enfants tunisiens d'âge scolaire également (Bellaj et al., 2015), et ce malgré la prise en compte de multiples indicateurs du fonctionnement exécutif.

\subsection{Quid de la comparaison entre cultures (travaux interculturels) ?}

Sur une échelle plus large, la culture dans laquelle un enfant naît et grandit pourrait jouer un rôle déterminant dans le développement de ses FE. Bien que les études interculturelles comparant le fonctionnement exécutif d'enfants issus de différentes cultures soient pour le moment relativement peu nombreuses, elles indiquent des résultats intéressants. Ces recherches ont essentiellement été conduites à ce jour auprès des civilisations chinoises et américaines. Par exemple, Lan et al. (2011) ont obtenu des résultats en faveur des enfants chinois par rapport aux enfants américains à des épreuves mesurant leurs capacités de mémoire de travail et de contrôle inhibiteur. De la même manière, d'autres auteurs (Sabbagh et al., 2006) ont montré de «meilleures » habiletés exécutives chez des enfants chinois à des tâches d'inhibition, de flexibilité mentale et d'impulsivité, par rapport à leurs homologues américains. D'après les auteurs, les hypothèses explicatives pourraient être liées à des facteurs d'ordres culturels et génétiques. En effet, la culture chinoise encourage précocement les enfants à faire preuve d'un bon contrôle comportemental (autorégulation) et cela dès la période préscolaire. Ce phénomène favoriserait le développement précoce de certaines habiletés exécutives telles que la capacité à se concentrer sur de longues périodes et à inhiber les distracteurs, ou encore l'aptitude à obéir et suivre des consignes. Sur le plan génétique, la répétition du gène Dopamine receptor $D_{4}(\mathrm{DRD} 4)$ de l'allèle 7 (associée à une augmentation du risque de trouble déficitaire de l'attention avec ou sans hyperactivité et donc de troubles exécutifs) serait une caractéristique 
très rare dans les populations asiatiques par comparaison aux populations américaines (prévalences respectives de 1,9\% contre 48,3\%), contribuant à expliquer les meilleures performances exécutives des enfants de culture chinoise.

Il est par ailleurs probable que le choix des outils sélectionnés, pour évaluer le fonctionnement exécutif des enfants issus de différentes cultures, soit potentiellement déterminant dans les résultats obtenus. Par exemple, les données recueillies grâce à l'utilisation de questionnaires d'évaluation des FE dans la vie quotidienne de plusieurs cultures ont montré de meilleures aptitudes en termes d'habiletés exécutives chez les enfants suédois, iraniens et espagnols par rapport aux enfants chinois, sur la base des observations parentales (Thorell et al., 2013). Ces résultats contredisent ceux des travaux décrits précédemment (qui montrent de meilleures performances chez les enfants chinois en regard des enfants américains) et pourraient s'expliquer par un jugement plus sévère des parents chinois envers leurs enfants, toujours en lien avec les exigences précoces sur le plan des capacités d'autorégulation (les mêmes qui conduisaient à supposer dans l'étude précédente de meilleures performances dans les tâches). Ces données en apparence contradictoires pourraient donc être liées aux méthodes d'évaluations utilisées, selon que celles-ci sont basées sur le témoignage d'un proche ou sur des tests de laboratoire, et qui dans les deux cas sont médiatisées par des facteurs culturels.

Afin de mieux comprendre comment les FE se développent dans différentes cultures et quels sont les potentiels « invariants exécutifs » d'une culture à l'autre, davantage de recherches comparant plusieurs cultures et contrastant différents types de mesures apparaissent donc nécessaires, ce qui nous conduit à aborder plus précisément les stratégies d'évaluation des FE chez l'enfant.

\section{L'évaluation des fonctions exécutives chez l'enfant}

\subsection{Problèmes inhérents à l'évaluation des FE (et à la culture...)}

L'évaluation des habiletés exécutives chez l'enfant constitue un enjeu scientifique majeur, dans la mesure où il s'agit d'une étape indispensable pour mieux comprendre le développement normal et perturbé des FE. Si les outils existants chez l'enfant sont désormais relativement nombreux et correspondent, pour la plupart, à des versions ludiques des tâches proposées chez l'adulte, ils comportent un certain nombre de limites parmi lesquelles les erreurs de mesure inhérentes aux tâches exécutives, leur caractère par définition multifactoriel, mais aussi le manque d'étalonnages normatifs appropriés dans le pays d'origine de l'enfant (pour une revue critique : Roy, 2015a, 2015b ; Roy et al., 2017). Ce dernier aspect constitue une entrave majeure à la prise en considération du contexte, en particulier sociodémographique, et par extension de la culture de manière plus large. 
Au vu des études empiriques détaillées précédemment, il semble aujourd'hui primordial de poursuivre et d'approfondir les recherches relatives à l'influence du contexte environnemental sur le développement exécutif chez l'enfant, à la fois au niveau intra- et interculturel. Pour autant, ces recherches doivent être conduites avec précaution, en particulier si les auteurs emploient des procédures méthodologiques en apparence similaires dans plusieurs pays. En effet, même si deux pays paraissent culturellement et géographiquement proches (à l'instar des postulats formulés dans la Nepsy II pour la proximité entre la France et les Pays-Bas : Roy, 2015a, pour une discussion critique), l'usage d'outils neuropsychologiques doit faire l'objet d'une adaptation propre à la culture du pays dans lequel il est utilisé, y compris si les deux pays partagent la même langue. Par exemple, on pourrait penser que l'usage d'un seul et même test en Belgique et en Suisse n'entraînera pas de conséquence sur les résultats obtenus alors qu'en réalité il existe bien des biais biopsychosociaux potentiels (Er-Rafiqi et al., 2017, pour plus d'explications).

Une étude conduite dans dix pays différents auprès d'individus âgés de 15 à 83 ans a ainsi montré que les différences en matière de données normatives sont si grandes qu'un individu peut se retrouver déficitaire si ses performances sont analysées avec les données du pays voisin (Fernandez \& Marcopulos, 2008). Ces données mettent en exergue les dangers de faux positif (mais aussi de faux négatif) qui guettent le clinicien (et le chercheur) dont la pratique serait focalisée sur l'usage d'un étalonnage provenant d'un autre pays, en particulier chez l'enfant pour qui l'interaction avec l'environnement est potentiellement accrue. Les résultats de cette étude soulèvent donc la question de la procédure d'évaluation clinique des enfants grandissant dans deux cultures différentes. Ils contribuent à souligner l'importance d'une évaluation réalisée sous un angle culturel, qui implique que les différences de performances doivent être analysées en prenant en considération l'ensemble des variables contextuelles (Bellaj \& Le Gall, 2016).

À cet égard, les tests psychométriques destinés à évaluer les fonctions cognitives des populations occidentales ne sont pas forcément adéquats pour évaluer les populations des quatre coins du monde. Chaque pays dispose de ses propres expériences culturelles et éducatives, et chaque épreuve cognitive entretient des relations particulières avec la performance scolaire qu'elle est supposée prédire dans une culture donnée (Van Devijver, 2010). Autrement dit, la traduction littérale d'un test dans une autre langue n'équivaut pas à son adaptation culturelle, laquelle doit s'efforcer de vérifier que le test évalue le même construit psychologique que sa version originale. Ce travail inclut plusieurs étapes de traduction d'une langue d'origine à une langue cible, puis une adaptation particulière et spécifique de certains items à la culture cible, et enfin une vérification de la validité de cet outil dans la culture visée.

Le test « classique » de Stroop constitue, dans le domaine de l'évaluation des FE, un très bon exemple pour illustrer et prolonger cette idée (Er-Rafiqi et al., 2017), dans la mesure où les résultats à cette épreuve peuvent être insidieusement biaisés par les particularités culturelles de chaque pays. En effet, le temps de prononciation des couleurs en langue marocaine, par exemple, est plus long qu'en français, ce qui est 
susceptible d'entraîner un temps global significativement accru dans la population correspondante, par rapport aux enfants français. Les données obtenues pourraient laisser penser que les enfants français sont meilleurs que les enfants marocains, alors qu'en réalité, elles sont simplement la conséquence d'une différence culturelle qui n'est pas en lien avec les habiletés exécutives recherchées à travers l'épreuve du Stroop. La nature non verbale des tâches n'est d'ailleurs pas forcément une alternative qui permet de contourner cet effet de la culture, et de s'affranchir de cette adaptation. Par exemple, les formes géométriques de la figure de Rey, typiques des cultures occidentales, pourraient représenter des difficultés supplémentaires pour les enfants issus du monde oriental, dont les formes sont communément arquées et beaucoup plus ondulantes. Dans ce contexte, un enfant français aura certainement plus de facilité à planifier la copie de la figure de Rey par rapport à un enfant tunisien, qui sera confronté à du matériel moins conventionnel en regard de sa culture. Autrement dit, qu'il soit de nature verbale ou non verbale, un test psychométrique sera indubitablement imprégné du contexte dans lequel il a été créé.

L'ensemble de ces questionnements incite à relativiser de manière considérable la façon de pratiquer l'évaluation des FE (et plus globalement l'évaluation neuropsychologique) chez l'enfant, en cas de données normatives non disponibles dans la culture d'appartenance du patient. L'interprétation des résultats doit être réalisée avec beaucoup de prudence dans la mesure où il peut être difficile de dire s'ils sont le reflet d'une authentique perturbation ou s'ils sont "simplement " la conséquence ou le reflet d'un biais culturel non contrôlé.

\subsection{Projet FEE et ses enjeux}

Initié il y a près de 9 ans, le projet Fonctions exécutives chez l'enfant (FEE) a cherché à mettre en place, via un groupe de recherche multicentrique, une série d'épreuves visant à évaluer différentes facettes du contrôle exécutif habituellement distinguées chez l'enfant incluant la planification, l'inhibition, la flexibilité mentale et la mémoire de travail (Roy et al., en cours ; Roy, 2015, pour une description). Initialement envisagée pour fournir aux cliniciens des épreuves psychométriques adaptées aux enfants et disposant d'un étalonnage et d'une validation clinique auprès de la population française, la démarche s'est progressivement inscrite dans une dynamique interculturelle incluant en particulier la Tunisie, le Maroc, le Liban et le Brésil.

L'objectif dans ce contexte est double. Il s'agit d'une part de favoriser l'évaluation plus systématique des FE dans différents pays qui ne disposent pas forcément d'outils fiables et/ou adaptés dans leurs contextes culturels respectifs. D'autre part, l'enjeu consiste à étudier le développement typique et perturbé des FE dans une perspective interculturelle, sur la base d'une méthodologie commune. Sur le plan théorique, les comparaisons interculturelles viseront à améliorer la compréhension du développement typique et perturbé des FE, en questionnant la place de la culture dans les modélisations actuelles et les éventuels invariants cliniques des troubles du contrôle 
exécutif d'une culture à l'autre. Dans cette perspective, les différentes épreuves du protocole FEE ont fait l'objet d'une adaptation et d'une traduction minutieuse, en respectant les consignes internationales proposées par l'International test commission (2017). Pour ce faire, plusieurs experts ont réalisé une procédure de Translation and backtranslation (Er-Rafiqi et al., 2017 ; Bellaj \& Le Gall, 2016, pour une description détaillée).

\section{3. Évaluation dite « écologique » des FE : complémentaire, nécessaire}

Les tests neuropsychologiques classiques permettent d'évaluer une fonction ou un ensemble de fonctions cognitives et de prévoir les difficultés qu'un individu pourrait avoir dans son quotidien. Chez l'enfant comme chez l'adulte, l'une des principales critiques formulées à l'égard de ces tests neuropsychologiques basés sur la performance aussi appelés tests de laboratoire a trait à leur absence potentielle de valence " écologique ». En d'autres termes, ces épreuves pourraient manquer de sensibilité dans la mesure où elles seraient relativement artificielles car trop structurées, explicites, en temps restreint, etc., si bien qu'elles ne refléteraient pas suffisamment l'engagement des FE dans les situations de vie quotidienne (Roy et al., 2012, 2017, pour une synthèse).

Dans ce contexte, compléter l'évaluation neuropsychologique « classique » par le biais d'une approche plus «écologique » permettrait de mieux comprendre l'impact d'un dysfonctionnement dans le quotidien de l'enfant et augmenterait ainsi la sensibilité de l'évaluation. Différents types d'outils ont été développés dans cette perspective, parmi lesquels des épreuves qui "simulent » l'engagement des FE dans la vie quotidienne de l'enfant via des situations moins "fermées " comme l'organisation d'une balade dans un zoo, ou l'observation directe en situation comme la préparation d'un gâteau au chocolat (Chevignard et al., 2010). Ces épreuves demeurent avant tout expérimentales pour le moment et ne disposent pas de validation en langue française. Les questionnaires comportementaux qui visent à appréhender les FE dans la vie quotidienne de l'enfant du point de vue de ses parents ou de l'enseignant constituent à ce niveau des alternatives intéressantes, à l'instar de l'inventaire d'évaluation comportementale des FE (behavior rating inventory of executive function [Brief] ; Gioia et al., 2000 ; Roy et al., 2013) ou du childhood executive functioning inventory (Chexi; Catale et al., 2015). La Brief présente l'avantage d'être largement étudiée dans de multiples contextes cliniques pédiatriques, sur la base d'un découpage factoriel entre deux grands facteurs que sont la régulation comportementale et la métacognition, chacun de ces domaines englobant les différentes facettes habituellement distinguées sur le plan théorique et clinique (contrôle émotionnel, inhibition, mémoire de travail, planification/organisation, etc.). La confrontation des versions "parent» et « enseignant » permet par ailleurs d'évaluer l'impact d'un dysfonctionnement exécutif tant à la maison qu'au sein de l'établissement scolaire de l'enfant, ce qui permettra 
d'apprécier son fonctionnement exécutif dans des contextes différents. Enfin, la structure factorielle de l'outil et ses propriétés psychométriques ont fait l'objet d'études de validation auprès de la population française (Fournet et al., 2015), avec une sensibilité clinique dans différents contextes cliniques (Campiglia et al., 2014 ; Charbonnier et al., 2011 ; Chevignard et al., 2017 ; Roy et al., 2015).

Il convient de souligner que, selon les études disponibles à ce jour, les questionnaires de vie quotidienne et les tests plus classiques basés sur la performance de l'enfant présentent une faible validité convergente (Toplak et al., 2013). Ces deux types d'outils sont donc à percevoir comme complémentaires dans la mesure où ils représentent de manière différente l'engagement des FE, chacune d'entre elles ne pouvant constituer à elle seule une garantie suffisante pour attester des troubles exécutifs. Ainsi, l'évaluation du retentissement fonctionnel, qui peut notamment se faire à l'aide de questionnaires, offre une complémentarité indispensable aux tests neuropsychologiques basés sur la performance, afin d'aboutir à un diagnostic fiable et à l'élaboration d'un plan de prise en charge adapté (Chevignard et al., 2012).

\section{La perturbation des fonctions exécutives chez l'enfant}

\subsection{Absence de critères de diagnostic mais plusieurs repères cliniques}

Il est désormais communément admis que les particularités développementales des régions préfrontales et des $\mathrm{FE}$ (à savoir leur maturation rapide mais prolongée) contribuent à un risque élevé de vulnérabilité précoce. Une atteinte directe ou indirecte des réseaux fronto-sous-corticaux en période prénatale, périnatale ou postnatale, en lien avec des lésions cérébrales acquises ou un trouble du neurodéveloppement, est ainsi susceptible d'avoir des conséquences désastreuses tant pendant l'enfance qu'à l'âge adulte, ce qui fait de l'évaluation de ces processus un enjeu de santé publique majeur (Roy et al., 2017).

Bien que de nombreuses perturbations du fonctionnement exécutif soient décrites dans la littérature, il n'existe toujours pas, aujourd'hui, de définition précise du syndrome associé à ces perturbations. En effet, son identification est entravée par l'absence de critères de diagnostic établis et par le manque d'outils standardisés et consensuels, comme cela a été évoqué précédemment. Par ailleurs, un dysfonctionnement exécutif pendant l'enfance et l'adolescence est d'autant plus difficile à objectiver que le comportement manifesté peut aisément être confondu avec les difficultés de contrôle typique des enfants et des adolescents (risque de faux négatif). En effet, on imagine difficilement un jeune enfant être capable de s'organiser spontanément, d'inhiber avec succès ses gestes, ses pensées, ses paroles, de différer ses envies ou plus globalement de réguler/contrôler de manière appropriée ses réactions. Cette difficile lecture clinique des 
symptômes dysexécutifs dans l'enfance peut perturber l'identification des troubles, d'autant plus en cas de mécanismes défensifs (déni de l'enfant et/ou des parents), ce qui retarde par définition la mise en place d'une prise en charge appropriée. À nouveau ici, le contexte sociodémographique et culturel dans lequel évolue l'enfant peut conditionner l'identification plus ou moins précoce des troubles des FE, selon, par exemple, les attentes ou les projections parentales propres à chaque situation.

Pour autant, plusieurs repères cliniques ont été identifiés ces dernières années, qui permettent de fournir un cadre de référence pour l'exploration clinique des troubles des FE chez l'enfant (pour une description plus précise : Roy, 2015 ; Roy et al., 2012, 2017). Ainsi, les perturbations du contrôle exécutif sont relativement fréquentes mais variables au sens où elles peuvent concerner un seul versant des FE (froid versus chaud), voire se manifester de manière assez dissociée ou prédominante au sein des troubles exécutifs cognitifs (exemple : inhibition versus flexibilité). Les troubles des FE sont par ailleurs généralement chroniques, et susceptibles de «s'aggraver » ou d'apparaitre de manière différée dans le temps, lorsque les exigences d'autonomie et d'indépendance sont accrues. Ils sont enfin susceptibles de retentir de manière sévère sur la qualité de vie de l'enfant et de ses proches, avec des répercussions dramatiques pour l'intégration et la réussite scolaire, sociale et professionnelle.

\subsection{Nombreux contextes cliniques concernés}

L'hypothèse d'un trouble du fonctionnement exécutif est désormais largement entérinée dans diverses pathologies neurodéveloppementales telles que les troubles spécifiques d'apprentissage, le trouble déficitaire de l'attention avec ou sans hyperactivité, le trouble du spectre autistique, mais aussi dans divers syndromes génétiques comme la neurofibromatose de type 1, la microdélétion 22q11.2, le syndrome de Turner ou encore la phénylcétonurie (voir, en particulier, Chapitres 14, 16, 17 et 18). De même, une perturbation des $\mathrm{FE}$ a été décrite dans divers cas de lésions cérébrales acquises plus ou moins précocement, comme le traumatisme crânien, la prématurité, l'épilepsie infantile ou les tumeurs cérébrales (voir, par exemple, Chapitres 20, 21 et 22).

Les populations à risque de présenter un dysfonctionnement exécutif ne concernent pas uniquement les enfants avec des troubles neurologiques acquis ou neurodéveloppementaux mais également ceux présentant diverses atteintes psychiatriques telles que la dépression, l'anxiété ou le trouble obsessionnel compulsif. Par exemple, une association significative a été identifiée entre l'accumulation compulsive (fait d'amasser une quantité importante d'objets sans valeur apparente, comme les journaux) retrouvée dans le trouble obsessionnel compulsif et les troubles du contrôle exécutif tels qu'appréhendés à travers la version «parent » de la BRIEF (Park et al., 2016). De même, une étude récente a montré que des garçons (de 9 à 11 ans), présentant un état de dépression et d'anxiété, affichaient des difficultés exécutives accrues en regard d'enfants contrôles dans une tâche évaluant les capacités de flexibilité mentale (Emerson et al., 2005). Dans une perspective clinique intégrative, 
plusieurs travaux récents réalisés dans la microdélétion 22q11.2 ont par ailleurs montré que les perturbations du fonctionnement exécutif pourraient participer ou contribuer aux manifestations psychopathologiques, en particulier psychotiques observées chez les enfants atteints de ce syndrome (voir Chapitre 18).

Des anomalies du développement exécutif ont également été identifiées chez des enfants concernés par divers problèmes de santé publique, tels que la prise de substance chez la femme enceinte (Minnes et al., 2016). Par exemple, les versions « parent » et l'autoévaluation (par l'enfant lui-même) de la BRIEF utilisées dans cette étude ont montré des problèmes de régulation comportementale et de métacognition chez des adolescents âgés de 12 et 15 ans, victimes d'une exposition prénatale à la cocaïne. D'autres travaux conduits en imagerie cérébrale ont identifié des anomalies du cortex cérébral, se traduisant notamment par une réduction du cortex cérébral au niveau des régions frontales, chez des enfants de 6 à 10 ans ayant été exposés à des polluants environnementaux pendant la vie foetale. Ces anomalies cérébrales sont susceptibles de conduire à une perturbation du contrôle inhibiteur pouvant entraîner des difficultés d'autorégulation, de l'impulsivité, ou encore à une hyperactivité (Guxens et al., 2018).

\subsection{Impact du dysfonctionnement exécutif sur le développement cognitif}

Compte tenu de la place centrale qu'occupent les FE pour le développement psychologique au sens large (Diamond, 2013), leur perturbation, même partielle, est susceptible de parasiter les différentes sphères du fonctionnement cognitif, voire de générer une forme de confusion quant à la nature et l'origine des symptômes. Les troubles du contrôle exécutif peuvent ainsi retentir sur les fonctions instrumentales ou contribuer à expliquer certains dysfonctionnements identifiés à ce niveau. Il a ainsi été montré qu'un sous-groupe d'enfants présentant les critères cliniques du trouble développemental de la coordination (TDC) est caractérisé par un dysfonctionnement exécutif susceptible de rendre compte d'une partie au moins de leurs troubles praxiques ou de coordination motrice (voir Chapitre 6 ; Costini et al., 2017, pour une revue). Le même type de résultats émerge d'une série de travaux réalisés auprès des enfants atteints de neurofibromatose de type 1 (NF1), qui montrent que les anomalies du contrôle exécutif cognitif, en particulier les stratégies organisationnelles et de planification fréquemment observées dans ce contexte clinique, expliquent certaines difficultés relevées à l'étage des praxies idéomotrices (digitales), des praxies visuo-constructives ou encore du traitement visuo-spatial (voir Chapitre 17).

De manière similaire, plusieurs travaux ont démontré que les perturbations de certaines facettes des FE, comme celles affectant la mémoire de travail ou la flexibilité cognitive, sont susceptibles d'entraîner des troubles dans l'acquisition de la lecture et des habiletés mathématiques (Morgan et al., 2017). Les liens entre habiletés exécutives et performances en mathématiques semblent d'ailleurs être particulièrement stables dans le temps, entre 8 et 25 ans (Cragg et al., 2017). Ces données sont à rapprocher 
de celles issues des travaux réalisés en psychologie du développement et en sciences de l'éducation, qui montrent le rôle essentiel du contrôle inhibiteur dans la capacité de l'enfant à corriger/dépasser les erreurs liées aux heuristiques, automatismes et conceptions naïves précédemment acquis (Houdé \& Borst, 2014 ; voir aussi Chapitre 25). Ces éléments vont dans le sens des liens étroits supposés entre processus exécutifs et réussite scolaire (Diamond, 2013), et illustrent à nouveau les risques qui s'associent plus globalement à une perturbation précoce du contrôle exécutif.

Enfin, des rapports étroits ont été identifiés entre l'émergence et le développement de la théorie de l'esprit et celui des processus exécutifs, dès la période préscolaire. Les travaux récents de Powell et Carey (2017) dans ce domaine ont, par exemple, montré que le développement des FE est essentiel pour développer des aptitudes à comprendre les fausses croyances présentes dans les activités de vie quotidienne. Une perturbation du fonctionnement exécutif chez des enfants de 5 ans a, dans ce contexte, une influence directe sur les capacités à prédire le comportement d'autrui. Dans une perspective interculturelle, une corrélation robuste a également été identifiée entre FE et théorie de l'esprit chez les enfants hongkongais et britanniques, résultat qui tend à favoriser l'idée d'un lien indépendant de la culture (Wang et al., 2016).

$\mathrm{Au}$ regard de ces différents liens qui ne représentent qu'une partie des travaux dans ce domaine, il apparaît évident que le repérage précoce du syndrome dysexécutif à l'âge préscolaire et/ou scolaire est essentiel pour apprécier leur impact potentiel sur les apprentissages scolaires, le développement cognitif et les interactions sociales.

\section{Conclusion}

La question des FE chez l'enfant est devenue un enjeu sociétal majeur notamment dans le champ de la santé publique. S'il est communément admis que les FE endossent le rôle d'un véritable «chef d'orchestre » de la cognition et qu'elles sont particulièrement vulnérables en cas d'atteinte chez l'enfant, plusieurs zones d'ombre persistent en particulier dans le domaine de leur expression clinique ou encore autour de l'implication de la culture dans leur développement. Malgré l'absence de critères de diagnostic précis, notamment dans le DSM-5 ou la classification internationale des maladies (CIM)-10, la perturbation du fonctionnement exécutif est au cœur d'un large spectre de contextes cliniques incluant les troubles neurodeveloppementaux et les pathologies acquises, mais aussi plus globalement la psychopathologie de l'enfant et de l'adolescent. Dès lors, une évaluation systématique de ces processus est nécessaire et doit s'appuyer à la fois sur des tests basés sur la performance (dits « de laboratoire») et sur des questionnaires (ou des tâches) de vie quotidienne. Cette démarche passe par la prise en compte du contexte et de la culture au sens large, afin d'identifier plus précisément ce qui, dans les apparentes difficultés de contrôle et d'adaptation suspectées dans l'approche neuropsychologique de l'enfant, relève avant tout ou principalement des facteurs environnementaux inhérents à son développement. 


\section{Références}

1. Ardila, A., Rosselli, M., Matute, E., \& Guajardo, S. (2005). The influence of the parents' educational level on the development of executive functions. Developmental Neuropsychology, 28(1), 539-560.

2. Bechara, A., Damasio, H., \& Damasio, A.R. (2000). Emotion, decision making and the orbitofrontal cortex. Cerebral Cortex, 10(3), 295-307. doi.org/10.1093/cercor/10.3.295

3. Bellaj, T., \& Le Gall, D. (2016). L'évaluation neuropsychologique dans le contexte du Maghreb. In H. Amieva, C. Belin, \& D. Maillet (Eds.), L'évaluation neuropsychologique De la norme à l'exception (pp. 165-90). Bruxelles : De Boeck supérieur.

4. Bellaj, T., Salhi, I., Le Gall, D., \& Roy, A. (2015). Development of executive functioning in school-age Tunisian children. Child Neuropsychology, 22(8), 919-954.

5. Berlin, L., \& Bohlin, G. (2002). Response inhibition, hyperactivity, and conduct problems among preschool children. Journal of Clinical Child \& Adolescent Psychology, 31, 242-251.

6. Bialystok, E., \& Viswanathan, M. (2009). Components of executive control with advantages for bilingual children in two cultures. Cognition, 112(3), 494-500.

7. Brocki, K. C., \& Bohlin, G. (2004). Executive functions in children aged 6 to 13: A dimensional and developmental study. Developmental Neuropsychology, 26(2), 571-593.

8. Campiglia, M., Seegmuller, C., Le Gall, D., Fournet, N., Roulin, J. L., \& Roy, A. (2014). Assessment of everyday executive functioning in children with frontal or temporal epilepsies. Epilepsy \& Behavior, 39, 12-20.

9. Carlson, S. M., \& Meltzoff, A. (2008). Bilingual experience and executive functioning in young children. Developmental Science, 11(2), 282-298.

10. Catale, C., Meulemans, T., \& Thorell, L.B. (2015). The Childhood Executive Function Inventory: Confirmatory factor analyses and cross-cultural clinical validity in a sample of 8-to11-year-old children. Journal of Attention Disorders, 19(6), 489-495. Doi:10.1177/1087054712470971

11. Charbonnier, V., Roy, A., Seegmuller, C., Gautier, A., \& Le Gall, D. (2011). Étude d'un cas de syndrome dysexécutif à prédominance cognitive chez un enfant présentant une épilepsie frontale symptomatique. Revue de Neuropsychologie, 3(1), 11-22.

12. Chevignard, M., Catroppa, C., Galvin, J., \& Anderson, V. (2010). Development and evaluation of an ecological task to assess executive functioning post childhood TBI: The children's cooking task. Brain Impairment, 11, 125-143.

13. Chevignard, M., Kerrouche, B., Krasny-Pacini, A., Mariller, A., Pineau-Chardon, E., Notteghem, P., ... \& Roy, A. (2017). Ecological assessment of everyday executive functioning at home and at school following childhood traumatic brain injury using the BRIEF Questionnaire. The Journal of Head Trauma Rehabilitation. 32(6), E1-E12. doi: 10.1097/HTR.0000000000000295

14. Chevignard, M., Soo, C., Galvin, J., Catroppa, C., \& Eren, S. (2012). Ecological assessment of cognitive functions in children with acquired brain injury: A systematic review. Brain Injury, 26(9), 1033-1057. Doi: 10.3109/02699052.2012.666366 
15. Costini, O., Remigereau, C., Le Gall, D., \& Roy A. (2017). Fonctions exécutives et Trouble Développemental de la Coordination : réflexion théorique et sémiologie clinique. Approche Neuropsychologique des Apprentissages chez l'Enfant, 146, 63-71.

16. Cragg, L., Keeble, S., Richardson, S., Roome, H. E., \& Gilmore, C. (2017). Direct and indirect influences of executive functions on mathematics achievement. Cognition, 162, $12-26$.

17. Crivello, C., Kuzyk, O., Rodrigues, M., Friend, M., Zesiger, P., \& Poulin-Dubois, D. (2006). The effects of bilingual growth on toddlers' executive function. Journal of Experimental Child Psychology, 141, 121-132.

18. Dennis, M. (2006). Prefrontal cortex: typical and atypical development. In J. Risberg \& J. Grafman (Eds.), The frontal lobes: development, function and pathology (pp. 128-62). New York, NY: Cambridge University Press.

19. Diamond, A. (2013). Executive Functions. Annual Review of Psychology, 64, 135-168.

20. Emerson, C., Mollet, G., \& Harrison, D. (2005). Anxious-depression in boys: an evaluation of executive functioning. Archives of Clinical Neuropsychology, 20(4), 539-546.

21. Er-Rafiqi, M., Roukoz, C., Le Gall, D., \& Roy, A. (2017). Les fonctions exécutives chez l'enfant : développement, influences culturelles et perspectives cliniques. Revue de Neuropsychologie, neurosciences cognitives et cliniques. 9(1), 27-34.

22. Fernández, A. L., \& Marcopulos, B. A. (2008). A comparison of normative data for the Trail Making Test from several countries: Equivalence of norms and considerations for interpretation. Scandinavian Journal of Psychology, 49(3), 239-246.

23. Fournet, N., Roulin, J. L., Monnier, C., Atzeni, T., Cosnefroy, O., Le Gall, D., \& Roy A. (2015). Multigroup confirmatory factor analysis and structural invariance with age of the Behavior Rating Invotory of Executive Function - French version. Child Neuropsychology: A Journal on Normal and Abnormal Development in Childhood and Adolescence, 21(3), 379-388.

24. Gioia, G. A., Isquith, P. K., Guy, S. C., \& Kenworthy, L. (2000). Behavior rating inventory of executive function. Odessa, FL: Psychological Assessment Ressources.

25. Guxens, M., Lubczyńska, M. J., Muetzel, R. L., Dalmau-Bueno, A., Jaddoe, V. W. V., Hoek, G., ... \& El Marroun, H. (2018). Air pollution exposure during fetal life, brain morphology, and cognitive function in school-age children. Biological Psychiatry. Advanced online publication. doi.org/10.1016/j.biopsych.2018.01.016

26. Halpern, D. F (2000). Sex differences in cognitive abilities (3rd ed.). Mahwah, NJ: Lawrence Erlbaum Associates, Inc.

27. Hoff, E. (2003b). The specificity of environmental influence: Socioeconomic status affects early vocabulary development via maternal speech. Child development, 74(5), 1368-1378.

28. Houdé, O., \& Borst, G. (2014). Measuring inhibitory control in children and adults: brain imaging and mental chronometry. Frontiers in Psychology, 5. doi:10.3389/fpsyg.2014.00616

29. Ismatullina, V., Voronin, I., Shelemetieva, A., \& Malykh, S. (2014). Cross-cultural Study of Working Memory in Adolescents. Procedia - Social and Behavioral Sciences, 146, 353-357. 
30. Lan, X., Legare, C. H., Ponitz, C. C., Li, S., \& Morrison, F. J. (2011). Investigating the links between the subcomponents of executive function and academic achievement: A crosscultural analysis of Chinese and American preschoolers. Journal of Experimental Child Psychology, 108(3), 677-692.

31. Lee, K., Bull, R., \& Ho, R. M. (2013). Developmental changes in executive functioning. Child Development, 84, 1933-53. doi: 10.1111/cdev.12096.

32. Lehto, J. E., Juujärvi, P., Kooistra, L., \& Pulkkinen, L. (2003). Dimensions of executive functioning: Evidence from children. British Journal of Developmental Psychology, 21(1), 59-80.

33. Luria, A. R. (1966). Higher cortical functions in man. New York, NY: Basic Books.

34. Minnes, S., Min, M. O., Short, E. J., Wu, M., Lang, A., Yoon, S., \& Singer, L. T. (2016). Executive function in children with prenatal cocaine exposure (12-15 years). Neurotoxicology and Teratology, 57, 79-86.

35. Miyake, A., Friedman, N. P., Emerson, M. J., Witzki, A. H., Howerter, A., \& Wager, T. D. (2000). The unity and diversity of executive functions and their contributions to complex "frontal lobe" tasks: A latent variable analysis. Cognitive Psychology, 41, 49-100.

36. Morgan, P. L., Li, H., Farkas, G., Cook, M., Pun, W. H., \& Hillemeier, M. M. (2017). Executive functioning deficits increase kindergarten children's risk for reading and mathematics difficulties in first grade. Contemporary Educational Psychology, 50, 23-32.

37. Park, J. M., Samuels, J. F., Grados, M. A., Riddle, M. A., Bienvenu, O. J., Goes, F. S., ... \& Geller, D. A. (2016). ADHD and executive functioning deficits in OCD youths who hoard. Journal of Psychiatric Research, 82, 141-148.

38. Pena, E. D., Bedore, L. M., \& Zlatic-Giunta, R. (2002). Category-generation performance of bilingual children: The influence of condition, category, and language. Journal of Speech, Language and Hearing Research, 45, 938-947.

39. Powell, L. J., \& Carey, S. (2017). Executive function depletion in children and its impact on theory of mind. Cognition, 164, 150-162.

40. Roy, A. (2015a). Les fonctions exécutives chez l'enfant : des considérations développementales et cliniques à la réalité scolaire. Development, 7(18-19), 13-40.

41. Roy, A. (2015b). Approche neuropsychologique des fonctions exécutives de l'enfant : état des lieux et éléments de prospective. Revue de neuropsychologie, neurosciences cognitives et cliniques, 7(4), 245-256.

42. Roy, A., Barbarot, S., Charbonnier, V., Gayet-Delacroix, M., Stalder, J.-F., Roulin, J.-L., \& Le Gall, D. (2015). Examining the frontal subcortical brain vulnerability hypothesis in children with Neurofibromatosis type 1: Are T2-weighted hyperintensities related to executive dysfunction? Neuropsychology, 29(3), 473-484. doi: 10.1037/neu0000151. Advance online publication: 2014.

43. Roy, A., Fournet, N., Roulin, J.-L., \& Le Gall, D. (2013). BRIEF Inventaire d'Evaluation Comportementale des Fonctions Exécutives (Adaptation Française de Gioia GA, Isquith PK, Guy SC, Kenworthy L). Paris: Hogrefe France Editions.

44. Roy, A., Le Gall, D., Roulin, J. L., \& Fournet, N. (2012). Les fonctions exécutives chez l'enfant : approche épistémologique et sémiologie clinique. Revue de Neuropsychologie, 4(4), 287-297. 
45. Roy, A., Lodenos, V., Fournet, N., Le Gall, D., \& Roulin, J. L. (2017). Le syndrome dysexécutif chez l'enfant : entre avancées scientifiques et questionnements. Approche neuropsychologique des apprentissages chez l'enfant, 146, 27-38.

46. Sabbagh, M. A., Xu, F., Carlson, S. M., Moses, L. J., \& Lee, K. (2006). The development of executive functioning and theory of mind. A comparison of Chinese and U.S. preschoolers. Psychological Science, 17(1), 74-81.

47. Seron, X., Van der Linden, M., \& Andrès, P. (1999). Le lobe frontal : à la recherche de ses spécificités fonctionnelles. In: M. Van der Linden, X. Seron, D. Le Gall \& P. Andrès (Eds.), Neuropsychologie des lobes frontaux (pp. 33-88). Marseille : Solal.

48. Thorell, L. B., Veleiro, A., Siu, A. F. Y., \& Mohammadi, H. (2013). Examining the relation between ratings of executive functioning and academic achievement: Findings from a cross-cultural study. Child Neuropsychology, 19(6), 630-638.

49. Toplak, M. E., West, R. F., \& Stanovich, K. E. (2013). Practitioner review: do performancebased measures and ratings of executive function assess the same construct? Journal of Child Psychology and Psychiatry, and Allied Disciplines, 54(2), 131-143. doi:10.1111/ jcpp.12001

50. Van Devijver, F. J. R. (2011). Bias and real differences in cross-cultural differences: Neither friends nor foes. In: F. J. R. Van Devijver, A. Chasiotis \& S. M. Breugelmans (Eds.), Fundamental questions in cross-cultural psychology (pp. 235-257). Cambridge: Cambridge University Press.

51. Wang, Z., Devine, R. T., Wong, K. K., \& Hughes, C. (2016). Theory of mind and executive function during middle childhood across cultures. Journal of Experimental Child Psychology, 149, 6-22.

52. Zelazo, P. D., \& Müller, U. (2002). Executive functions in typical and atypical development. In: U. Goswami (Eds.), Handbook of childhood cognitive development (pp. 445-69). Oxford: Blackwell. 


\section{ANNEXE 3}

\section{لدراسة الوظانف التفينية لاى الطقل notice d'information دليل الإخبار}

مبيني، مبيدي

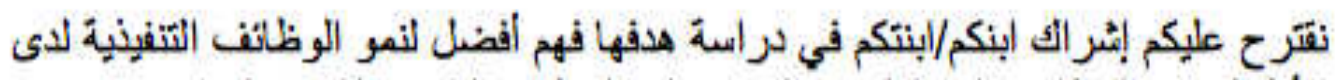
الاطفال. إن الوظاتف التنفينية هي القدرة على التنظيم والتكيف الذاتيين لتحقيق هدف هعين

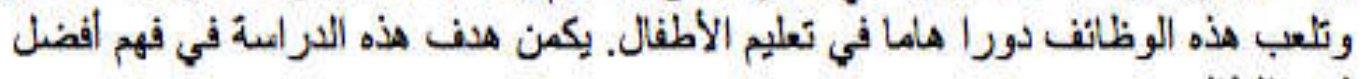
ل النمو الطقل.

إن الاختبر ات المقترحة على الأطفال تعد مهاما بعبطة وممتعة، وتتطلب، على مبيل

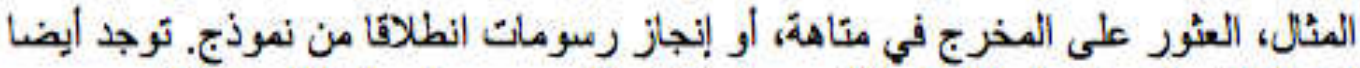

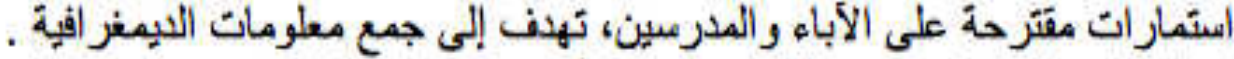

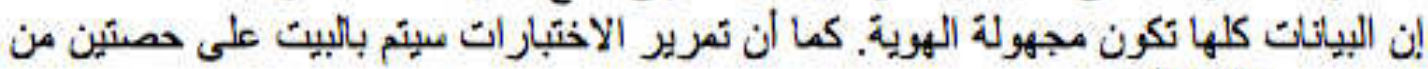
مباعة وبموافقة الأهل. 


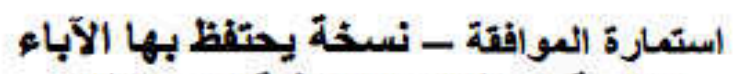

دراسة الوظاتف التفينية لدى الطقل

المعطيات :

اخذت علما بالدراسة المنكورة اعلاه. وعليه، يمكنتي ويمكن لابني/ابنتي طرح اي

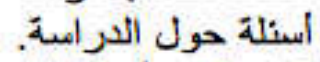

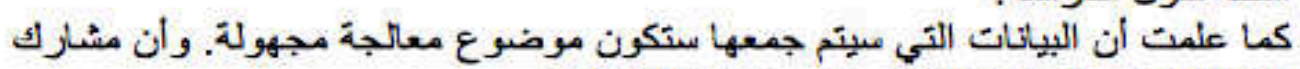

ابنذ/ابنتا في الدر امة المقركة البرة حرة وبشكل تطوعي.

احتفظ بنسخة موثعة من الوثيقةً الحالية.

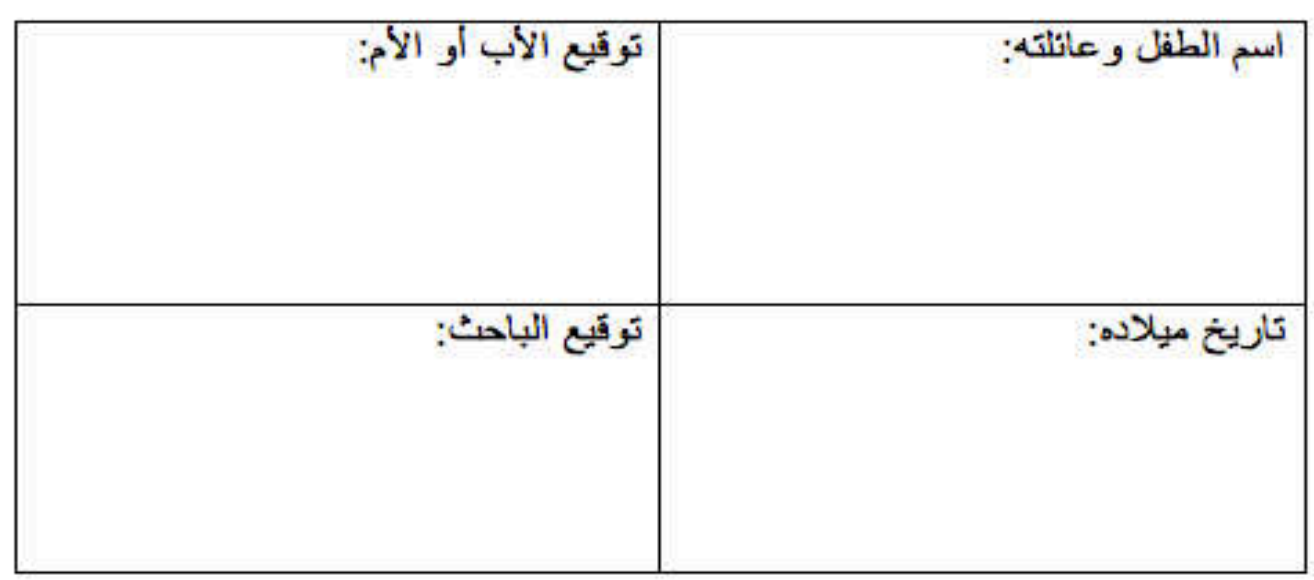




\section{ANNEXE 4}

\section{بزاسة الوظاتف التفيذية لاى الطقل}

جع العطوبات المتعلة بابنكم/ابنتكم

$$
\begin{aligned}
& \text { ميدني، مبدي، } \\
& \text { في إطلار معادهة ابنكم/ابنتكم في مشروع نر اسة الوظائف الثتفيذية، فإنتانحتاج إلى عنيد من }
\end{aligned}
$$

\begin{tabular}{|c|c|}
\hline$\cdots$ & العائلة : الطفل: \\
\hline | . . . . . . . . . . . . . . . . . . . . . . لشومر/السنة) & 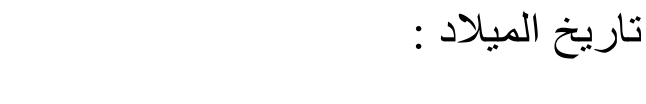 \\
\hline ذكر $\square$ & الجنس: \\
\hline $\begin{array}{l}\ldots \ldots \ldots \ldots \ldots \ldots \ldots \ldots \ldots \ldots \ldots \ldots \ldots \\
\ldots \ldots \ldots \ldots \ldots \ldots \ldots\end{array}$ & العل \\
\hline 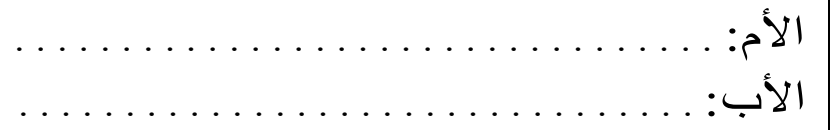 & مستوى التعليم (أعلى شهادة حصلتم عليها) \\
\hline & عدد الاخوةو/أو الأخوات لابنكم المساهم في \\
\hline 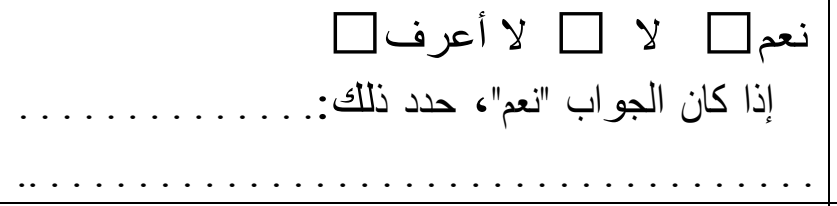 & 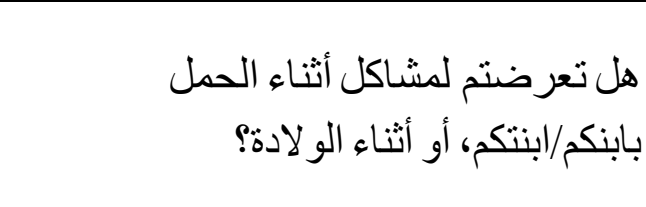 \\
\hline 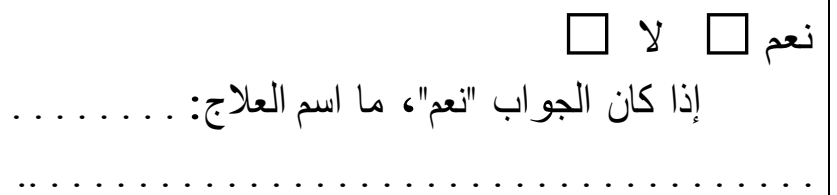 & هل يخضع ابنكم/بنتكم حاليا لعلاجات طبية؟ \\
\hline$\cdots$ & في أي صف يوجد ابنكم/بنتكم؟ \\
\hline 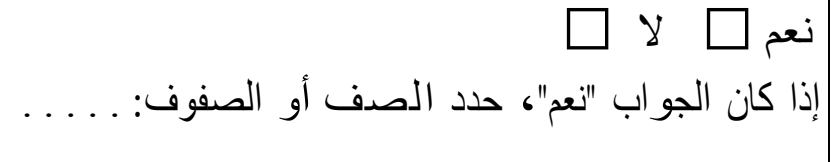 & هل كرر ابنكم/بنتكم صفا معينا؟ \\
\hline 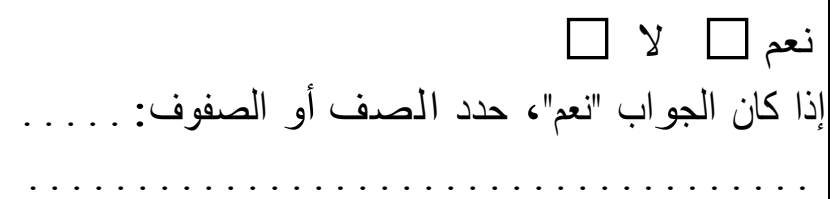 & 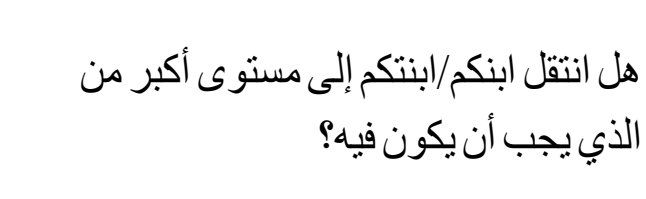 \\
\hline
\end{tabular}

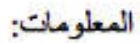




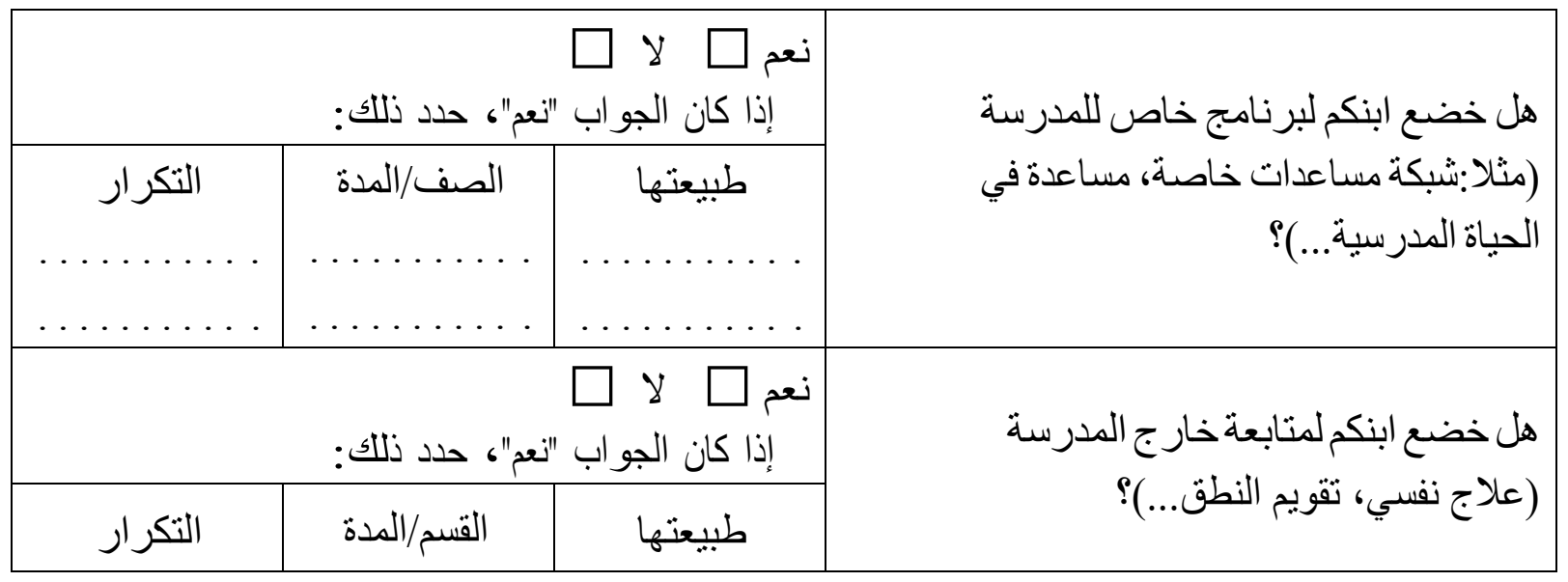

\begin{tabular}{|c|c|}
\hline 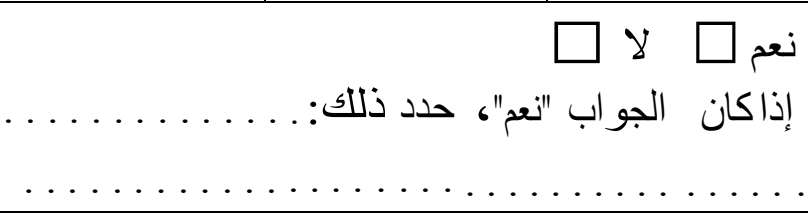 & 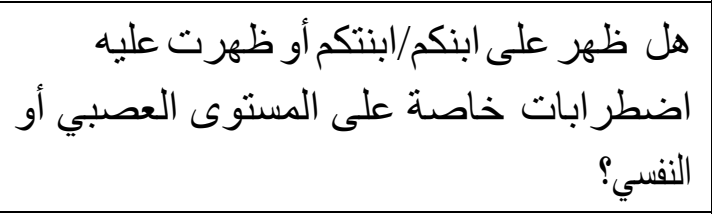 \\
\hline 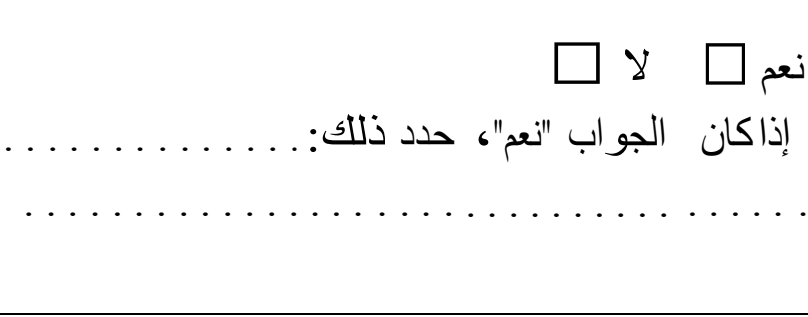 & 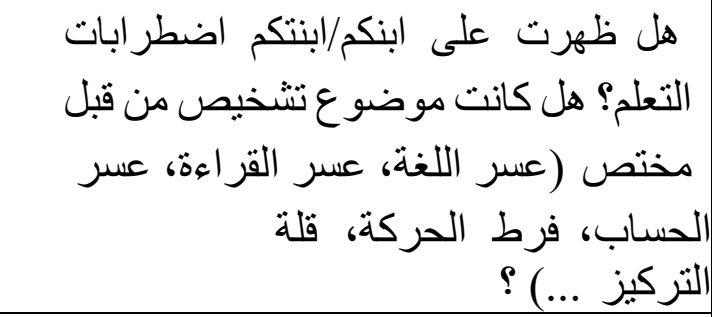 \\
\hline 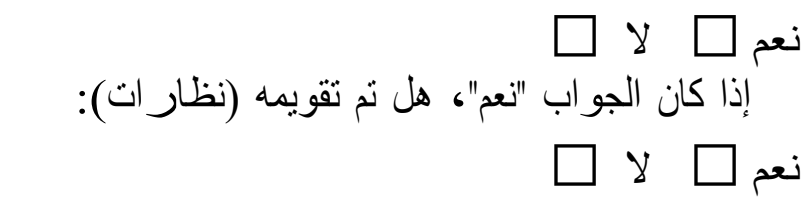 & هل لدى ابنكم/ابنتكم مشاكل في النظر؟ \\
\hline 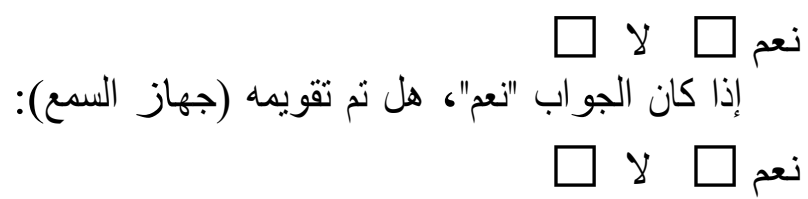 & هل لدى ابنكم/ابنتكم مشاكل في السمع؟ \\
\hline
\end{tabular}

$$
\text { نشكركم على الوقت الذي خصصنموه للاجابة على }
$$




\section{ANNEXE 5}

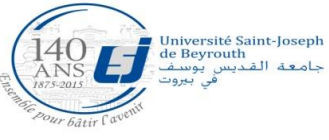

استمارة

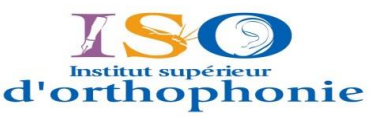

Nom de l'enfant :

Date de l'entretien

Nom de l'expérimentateur :

Entretien avec mère $\square$ père $\square$

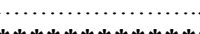

$* * * * * * * * * * * * * * * * *$

PaBiQ (Questionnaire pour parents d'enfants bilingues)COST IS0804 ${ }^{1}$

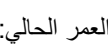

1. 1 المعلومات عامَّة عن الولد 1 1.1

مكان الولادة (البلد) :

1.2اذا مكان الولادة غير مكان النكن الحالي, تاريخ الوصول على البلد الحالي:

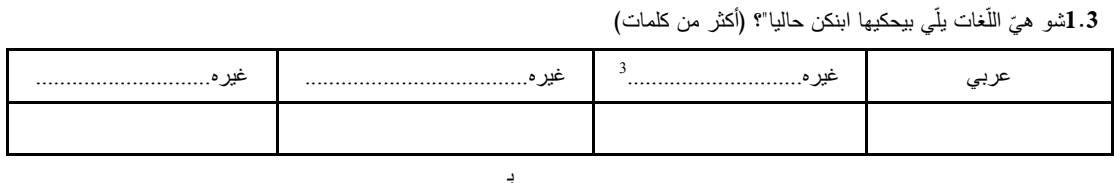

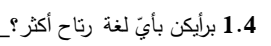

2. قصّة نمو الطُّل : النّطق و غيره

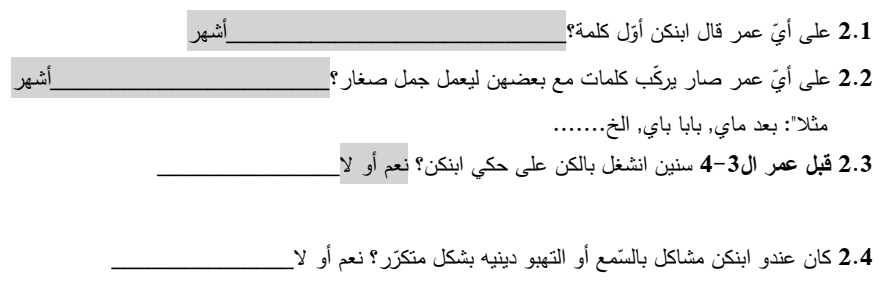

2.5 على أيّ عمر بلّش التَعرض لكلّ وحدة من هاللّات ( contact absolu"

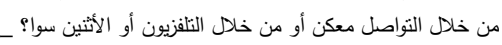

${ }^{1}$ Ce questionnaire est une traduction/adaptation du Questionnaire for Parents of BilingualChildren (COST Action IS0804, 2011). Il s'agit de la version courte d'un questionnaire plus long piloté par des groupes de recherche dans plusieurs pays de l'Action COST IS0804, qui a été en partie basé sur l'ALEQ (Paradis, 2011) et sur l'ALDeQ (Paradis et al., 2010).

${ }^{2}$ Les cases grisées seront à reporter sur la page de synthèse (p. 8).

${ }^{3}$ Préciser la langue.

${ }^{4}$ L'âge du premier contact absolu : correspond à l'âge auquel l'enfant a été en contact avec chaque langue pour la première fois que ce soit par

l'intermédiaire des échanges ou des medias. Par exemple pour enfant arménien, l'âge du premier contact absolu au libanais est à la naissance si

l'enfant est né au Liban, même si on ne s'adresse pas à l'enfant en libanais dans son entourage d'une façon directe. 


\begin{tabular}{|c|c|c|c|}
\hline العمر (بالأشهر إذا أمكن) & & العمر (بالأشهر إذا أمكن) & \\
\hline العمر & غيره........................... & العصر & عربي \\
\hline 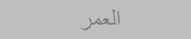 & غيره.......................... & 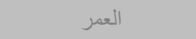 & غيره.................... \\
\hline
\end{tabular}

2.6 بشكل عام, قبل عمر ال4 سنين,هل تعرّض إبنكن لل ؟

\begin{tabular}{|c|c|c|c|c|c|}
\hline $\begin{array}{c}\text { أغلب الأوقات } \\
\text { دايمات } \\
\end{array}$ & غالبا" & نصف الوقت 2 & 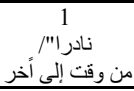 & أبدا" 5 & \\
\hline & & & & & عربي \\
\hline & & & & & غيره................... \\
\hline & & & & & غيره........................ \\
\hline
\end{tabular}

(contact significatif ${ }^{6}$ ) معبل عمر المَّه, أبوهـ...

أو تعرّض للمواقف التالية (نعم/لا) ؟ابتذاء من أيَ عمر (بالأشهر) حصل هيدا التعرّض؟ وضع العمر في الخانة المناسبة لكلّ لغة

\begin{tabular}{|c|c|c|c|c|}
\hline غيره......................... & غيره........................ & عربي & الإطار قبل 4 سنين & \\
\hline العمر & العمر & العقر & نعم/لا & تو تو اصل مع الأمَّ \\
\hline الحمر & العمر & العمر & نعم/لا & تو اصل مع الأبّ \\
\hline التعمر & التعمر & التعرز & نحم/لا & تو اصل مع جذَو و سنُّ \\
\hline العمر & العمر & العمر & نعم/لا & تو اصل مع المربيَّة \\
\hline العمر & العمر & الحمر & نعم/لا & تو اصل مع غير أشخاص كبار (تحديد) \\
\hline العمر & العمر & الحمر & نعم/لا & تو اصل مع اخو اته \\
\hline العمر & العمر & الحمر & نعم/لا & Garderie, crèche/ الحضانة \\
\hline العمز & العمر & التعرز & نعح/لا & المدرسة / Ecole maternelle \\
\hline $\mathrm{C}$ & B & A & $\mathrm{T}$ & 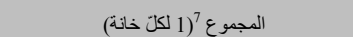 \\
\hline $\mathrm{C} / \mathrm{T}$ & $\mathrm{B} / \mathrm{T}$ & $\mathrm{A} / \mathrm{T}$ & & نسبة التعرَض لكلَ لغة \\
\hline
\end{tabular}

${ }^{5}$ Proposer tous les choix aux parents avant qu'ils ne répondent (chiffres et mots tels qu'ils sont écrits) et leur fournir aux parents les précisions suivantes :

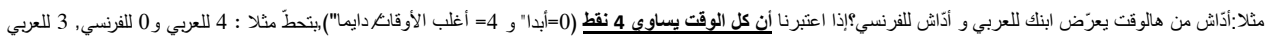

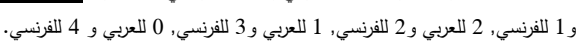

${ }^{6}$ L'âge du premier contact significatif : correspond au début de l'exposition réelle à chaque langue (si par exemple un enfant n'est pas en contact avec le français avant la maternelle, l'âge du premier contact significatif sera autour de 3 ans).

${ }^{7}$ Le nombre total de contextes de contact peut varier d'un enfant à un autre. Toutefois on garde le nombre de l'ensemble de contextes fixe dans le calcul du «taux d'exposition à chaque langue » même si un interlocuteur X n'a pas été un partenaire de communication pour une langue $\mathrm{X}$. 


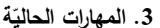

\begin{tabular}{|c|c|c|c|c|}
\hline غيره......................... & غيره........................ & غيره......................... & عربي & \\
\hline 3210 & 3210 & 3210 & 3210 & 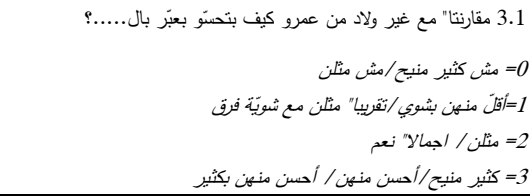 \\
\hline 3210 & 3210 & 3210 & 3210 & 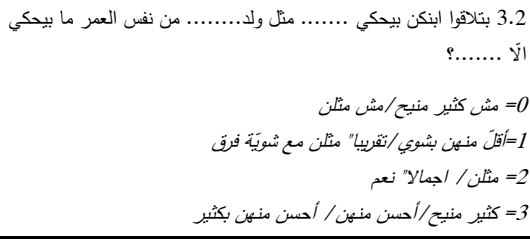 \\
\hline 3210 & 3210 & 3210 & 3210 & 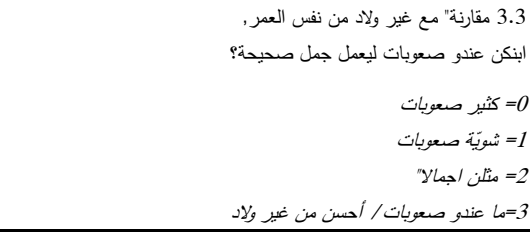 \\
\hline 3210 & 3210 & 3210 & 3210 & 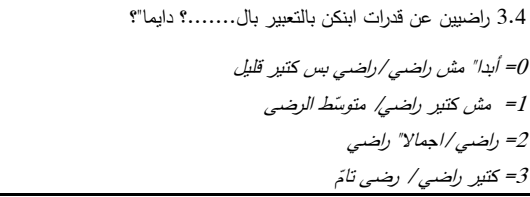 \\
\hline 3210 & 3210 & 3210 & 3210 & 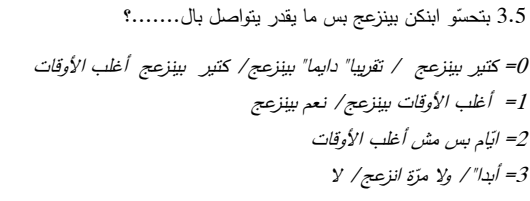 \\
\hline$/ 15$ & $/ 15$ & $/ 15$ & $/ 15$ & مجموع كلّ لغة \\
\hline
\end{tabular}

4. مقارنة بين اللَّات يلَّي تستعمل مع العيلةة 8.1

4.1

\begin{tabular}{|c|c|c|c|c|c|c|c|c|c|c|}
\hline \multicolumn{5}{|c|}{ الولد ه الأب } & \multicolumn{6}{|c|}{ الولد ↔ الأمّ } \\
\hline الأوقاتب 4 & غالبا" 3 & نصف & 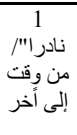 & أبدا" 0 & الأوقاتب 4 & غالبا" 3 & نصف & نادر إ" إلى أخر & أبدا" 0 & \\
\hline & & & & & & & & & & عربي \\
\hline & & & & & & & & & & غيره.............. \\
\hline & & & & & & & & & & غيره................. \\
\hline & & & & & & & & & & غيره............... \\
\hline
\end{tabular}

${ }^{8}$ Fournir aux parents les précisions suivantes :

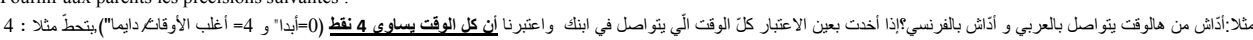

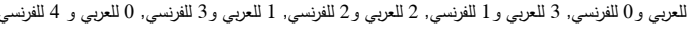


4.2 في غير شخص كبير و بيهنتّ بابنكن بشكل دايج؟ (جدَو ,ستَّ , المربيّة أو العاملة في المنزل... نعم أو لا

\begin{tabular}{|c|c|c|c|c|c|}
\hline \multicolumn{5}{|c|}{ الولا ↔هذا الشخص } & \\
\hline أغلب الأوقات/ دايما" & غالبا" & نصف الوقت & $\begin{array}{c}1 \\
\text { من وقت إلى أخر } \\
\text { أخر }\end{array}$ & أبدا" & \\
\hline & & & & & عربي \\
\hline & & & & & غيره................ \\
\hline & & & & & غيره.................. \\
\hline & & & & & غيره................ \\
\hline
\end{tabular}

\begin{tabular}{|c|c|c|c|c|c|}
\hline \multicolumn{6}{|c|}{ الأخوة >>>> الولد } \\
\hline أغلب الأوقار & غالبا" 3 & نصفت 2 & 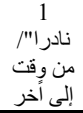 & أبدا" & \\
\hline & & & & & عربي \\
\hline & & & & & غيره................ \\
\hline & & & & & غيره............... \\
\hline & & & & & غيره............. \\
\hline
\end{tabular}

مجموع الأشخاص الذين يتواصل معهم الولد=...

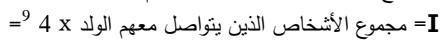

\begin{tabular}{|c|c|c|c|}
\hline 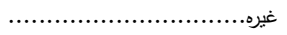 & 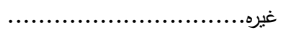 & عربي & \\
\hline 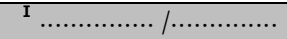 & 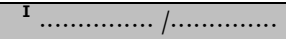 & ${ }^{\mathrm{I}} \ldots \ldots \ldots \ldots \ldots, / \ldots \ldots \ldots \ldots \ldots$ & مجموع استعمال اللَغة ضمن العائلة \\
\hline
\end{tabular}

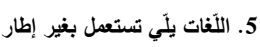

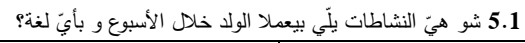

\begin{tabular}{|c|c|c|c|c|c|c|c|c|c|}
\hline \multicolumn{3}{|c|}{ 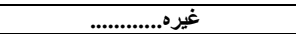 } & \multicolumn{3}{|c|}{ 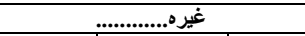 } & \multicolumn{3}{|c|}{ عربي } & \multirow[b]{2}{*}{ النشاطات } \\
\hline كل يوم & بالقاليلة مرّة & 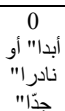 & كل يل يوم & بالقليلة مرَة & 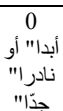 & كل كل يوم & بالقليلة مرّة & ندادرا" أو " أو & \\
\hline & & & & & & & & & قر اءة (الكتّب) , الصحف , , \\
\hline & & & & & & & & & مشاهدة التلفزيون أو الأفلام \\
\hline & & & & & & & & & اخبار أحداث أو قصص \\
\hline & & & & & & & & & المجموع \\
\hline \multicolumn{3}{|c|}{16} & \multicolumn{3}{|c|}{16} & \multicolumn{3}{|c|}{16} & مجموع كلّ لغة \\
\hline
\end{tabular}

${ }^{9}$ Exemple

1. Un enfant en contact avec les 4 interlocuteurs mentionnés: $I=4 \times 4=16$

2. Un enfant n'ayant pas de frères ou de søurs : $I=3 \times 4=12$. 
5.2 5شوهيَ اللَّة يلَّي تستعمل بينو و بين أصحابو يلّي بشوفهن غالبا" أو بشكل دائم؟

\begin{tabular}{|c|c|c|c|c|c|}
\hline \multicolumn{6}{|c|}{ الولا هـالأصحاب } \\
\hline أغلب الأوقات/ دايما" & غالبا" & نصف الوقت & 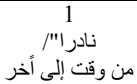 & أبدا" & \\
\hline & & & & & كربي لمي كرب \\
\hline & & & & & 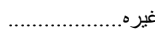 \\
\hline & & & & & غبره..................... \\
\hline & & & & & غير ه............... \\
\hline
\end{tabular}

\begin{tabular}{|c|c|c|c|c|c|}
\hline أغلب الأوقات/ دايما" & غالبا" 3 & نصف الوقت & $\begin{array}{c}1 \\
\text { من وقت إلى أخر } \\
\text { أخر }\end{array}$ & أبدا" 00 & ب ب العيلكة ؛ \\
\hline & & & & & عربي \\
\hline & & & & & غيره.................... \\
\hline & & & & & غبره................... \\
\hline & & & & & غيره................... \\
\hline
\end{tabular}

\begin{tabular}{|c|c|c|c|}
\hline 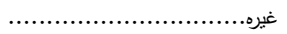 & 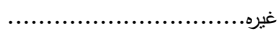 & عربي & \\
\hline $14 / \ldots \ldots \ldots \ldots \ldots$ & $14 / \ldots \ldots \ldots \ldots . .$. & $14 / \ldots$ & مجموع استعمال اللّغة ضمن المحبط 5.3 +5.2 +5.1 \\
\hline
\end{tabular}

6. ع معلومات عن الأمَ و الأب

6.1

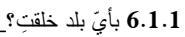

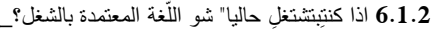

\begin{tabular}{|c|c|c|c|}
\hline توضيحات & عدد السنوات & & \\
\hline & & نعم أو لا & الصفوف الابتدائيّة \\
\hline & & نعم أو لا & الصفوف الثانويّة \\
\hline & & نعم أو لا & الجامعة \\
\hline & & نعم أو لا & مهنيّة \\
\hline
\end{tabular}


6.1 .4 حسب رأيكن شو هوّي مستواكن بال: (علامةX في الخانة الملناسبة)

\begin{tabular}{|c|c|c|c|c|c|}
\hline $\begin{array}{c}4 \\
\text { ممتازة } \\
\text { (بسهولة) }\end{array}$ & $\begin{array}{c}3 \\
\text { جيّّ } \\
\text { (بارتياح) }\end{array}$ & 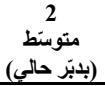 & 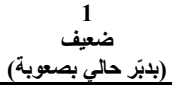 & 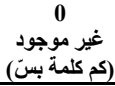 & \\
\hline & & & & & عربي \\
\hline & & & & & غيره.......................... \\
\hline & & & & & غيره.......................... \\
\hline & & & & & غيره.............................. \\
\hline
\end{tabular}

6.2 معلومات عن الأب 6.2

6.2.1

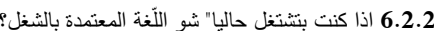

\begin{tabular}{|c|c|c|c|}
\hline توضيحات & عدد السنو ات & & \\
\hline & & نعم أو لا & الصفوف الابتدائيّة \\
\hline & & ن نعم أو لا & الصفوف الثانويَّة \\
\hline & & ن نعم أو لا & الجامعة \\
\hline & & نعم أو لا & مهنيّة \\
\hline
\end{tabular}

6.2.4 حسب رأيكن شو هوّي مستواكن بال: (علامةX في الخانة الملناسبة)

\begin{tabular}{|c|c|c|c|c|c|}
\hline 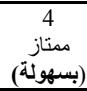 & 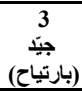 & 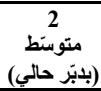 & 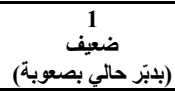 & 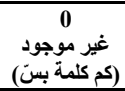 & \\
\hline & & & & & عربي \\
\hline & & & & & غيره.......................... \\
\hline & & & & & غيره........................ \\
\hline & & & & & غيره.......................... \\
\hline
\end{tabular}

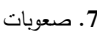

في كلّ خانة, الجواب بـ "نعم" (1) أو "لا" (0):

\begin{tabular}{|c|c|c|c|c|}
\hline \multicolumn{2}{|r|}{ 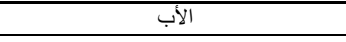 } & 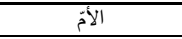 & الأخوة & \\
\hline & & & & صعوبات بالقراءة و الكتابة \\
\hline & & & & صعوبات بفهم النّاس وقت بيحكو اللَغة الأمّ \\
\hline \multirow{2}{*}{ | مجموع الصعوبات : } & & & & الخ.) باللَّغة الآتَّبِر شفهيًا" (لفظ, تركيب جمل, اختبار الكلمات, \\
\hline & $3 / \ldots \ldots \ldots \ldots \ldots \ldots \ldots$ & 3/................ & $3 / \ldots \ldots$ & 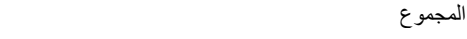 \\
\hline
\end{tabular}




\section{ANNEXE 6}

نسخة الولي

\section{BRIEF}

تاريخ الميلاد: ........

البلد:

المستوى الدر اسي: . . . .

علاقتك بالطفل:

اسم الطفل ولقبه:

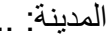

اسم المدرسة: .

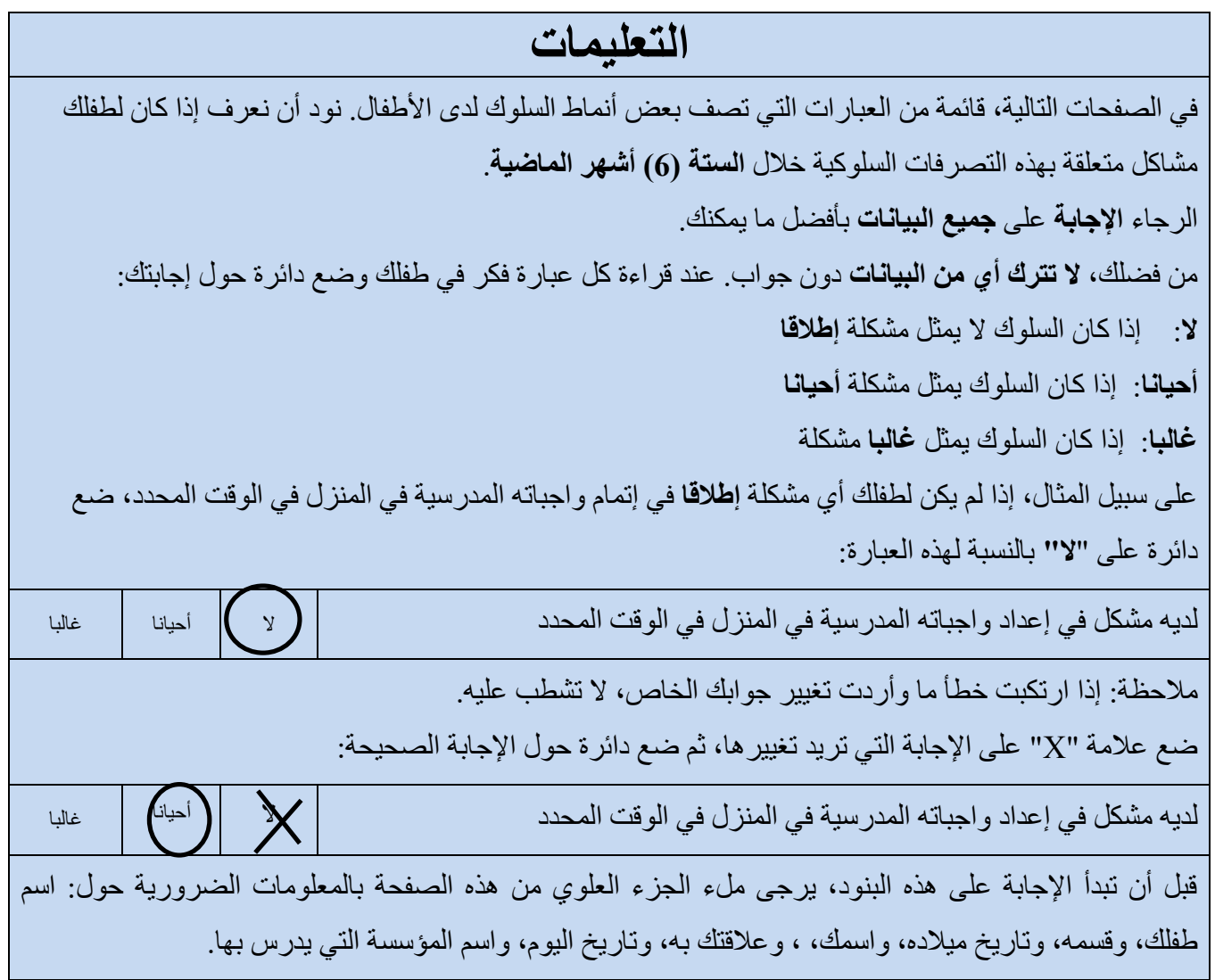


نسخة الولي

\begin{tabular}{|c|c|c|c|c|}
\hline \multicolumn{3}{|c|}{ 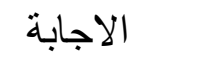 } & \multicolumn{2}{|l|}{ 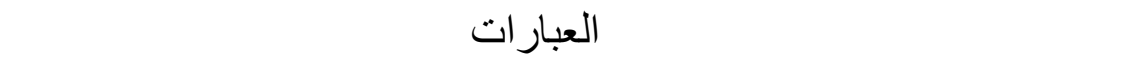 } \\
\hline غالبا & أحيانا & ४ & يتسم برد فعل مفرط أمام المشاكل البسيطة & .1 \\
\hline غالبا & أحيانا & ע & عندما يطلب منه القيام بثلاثة أثنياء، يتذكر فقط الثنيء الأول أو الأخير منها & .2 \\
\hline غالبا & أحيانا & ע & لا ييدأ أي شيء من تلقاء نفسه (لا يتَّذ المبادرة) & .3 \\
\hline غالبا & أحيانا & ४ & | يترك غرفة الألعاب في حالة فوضى & .4 \\
\hline غالبا & أحيانا & $\gamma$ & الأصدقارض، أو يجد الأعموبة في قبولية، ومريقة إلى ذختلفة لحل مشكلة في إطار العمل المدرسي مع & \\
\hline غالبا & أحيانا & ४ & 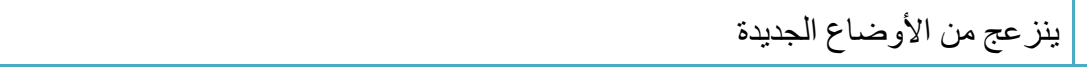 & .6 \\
\hline غالبا & أحيانا & ע & تظهر عليه نوبات غضب قوية & .7 \\
\hline غالبا & أحيانا & ४ & يحاول استعمال نفس النهج مر ار ا وتكر ار ا من أجل حل مشكلة حتى و إن لم يفلح فيه & .8 \\
\hline غالبا & أحيانا & ४ & ل لديه قدرة محدودة على الانتباه & .9 \\
\hline غالبا & أحيانا & ४ & لا يقوم بمهامه من تلقاء نفسه، رغم رغبته في القيام بها & .10 \\
\hline غالبا & أحيانا & $\gamma$ & · المدرسية... لا يعود المنزل بو اجباته الددرسية، وبالمطبو عات التي يعطيها له الددرس، وبأدو اته & .11 \\
\hline غالبا & أحيانا & ע & . ينز عج من أي تغيير في البرامج أو الخطط & .12 \\
\hline غالبا & أحيانا & y & . تغيير الددرس أو الفصل الدراسي يجعله مضطربا. & .13 \\
\hline غالبا & أحيانا & y & . لا ير اجع و لا يتثبت من عمله لمعرفة ما إن كان هناك أخطاء & .14 \\
\hline غالبا & أحيانا & y & . لايه أفكار جيدة لكنه لا بستطيع أن يعبّر عنها كتابيّا & 15 \\
\hline غالبا & أحيانا & y & . من الصعب عليه العثور على أفكار للعب أو قضاء وقت الفراغ & 16 \\
\hline غالبا & أحيانا & y & · يجد صعوبة في التركيز على المهام اليومية، والعمل المدرسي، وما إلى ذلك & 17 \\
\hline غالبا & أحيانا & ע & • ل لا يربط بين القيام بو اجباته المدرسية في المنزل الدرجات المتحصل عليها في الددرسة. & .18 \\
\hline غالبا & أحيانا & ע & · يتشتت انتباهل بسهولة عند سماع أصوات أو رؤية صور أو حركات بجانبه أو أية أثنياء أخرى & .19 \\
\hline غالبا & أحيانا & ע & 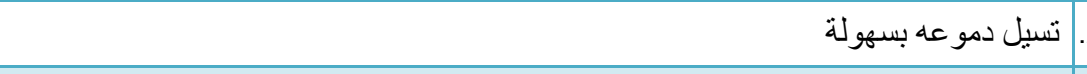 & .20 \\
\hline غالبا & أحيانا & y & . يرتكب أخطاء ناتجة عن قلة الانتباه. & .21 \\
\hline غالبا & 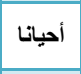 & y & . ينسى تسليم و اجباته المدرسية حتى عندما ينجز ها & .22 \\
\hline غالبا & أحيانا & y & ـ يعارض التغيير ات التي قد تطر أ على روتين حياته اليومية، العادات، و التغذية، والأماكن، وغير ها & .23 \\
\hline غالبا & أحيانا & y & ـ يصعب عليه أداء مهامه اليومية أو الأنشطة التي تتطلّب أكثر من خطوة و احدة. & .24 \\
\hline غالبا & أحيانا & ४ & . تنتابه نوبات غضب لأتفه الأشياء. & .25 \\
\hline غالبا & 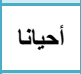 & y & 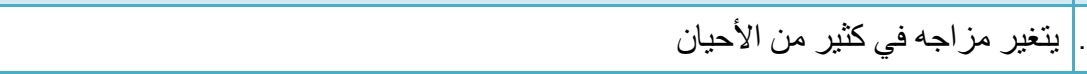 & .26 \\
\hline غالبا & 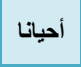 & ע & ـ يحتاج إلى مساعدة الكبار لمتابعة نشاط ما & .27 \\
\hline
\end{tabular}




\begin{tabular}{|c|c|c|c|c|}
\hline غالبا & 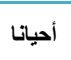 & ע & |يركّز على التفاصيل أكثر من الصورة العامة & .28 \\
\hline غالبا & أحيانا & ע & 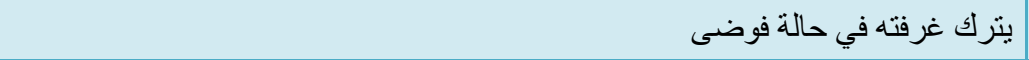 & .29 \\
\hline غالبا & أحيانا & ע & يجد صعوبة في التعوّد على الأوضاع الجديدة (قاعات الدرس، المجموعات، الأصدقاء) & .30 \\
\hline غالبا & أحيانا & ע & | يكتب بخط رديء & .31 \\
\hline غالبا & أحيانا & ע & | ل ينسى الأعمال التي كان يقوم بها & .32 \\
\hline غالبا & أحيانا & ע & عندما نرسله لإحضار شيء ما، ينسى ما كان من المفترض أن يحضره & .33 \\
\hline غالبا & أحيانا & ४ & لا يدرك مدى تأثير سلوكه على الآخرين أو مدى إزعاجه لهم & .34 \\
\hline غالا & 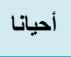 & ע & لديه أفكار جيّدة، لكنه لا ينهي عمله (يفتقر إلى المتابعة و المو اصلة) & .35 \\
\hline غالبا & أحيانا & ע & يصبح مرتبكا ومغلوبا على أمره عندما تتكاثر عليه المهام & .36 \\
\hline غالبا & أحيانا & ע & يعاني من صعوبة الانتهاء من المهام (المهام اليومية و الواجبات المنزلية) & .37 \\
\hline غالبا & أحيانا & ע & الراحة) بتصرف بطريقة عنيفة أو طفلية أكثر من أنداده في المجموعة (حفلات أعياد الميلاد، فترة & .38 \\
\hline غالبا & أحيانا & ע & يفكّر أكثر من اللازم في الموضوع نفسه & 39 \\
\hline غالبا & 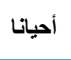 & ४ & يقلل من تقدير الوقت اللازم لإنهاء المهام (عمل، أو نشاط) & .40 \\
\hline غالبا & أحيانا & $y$ & 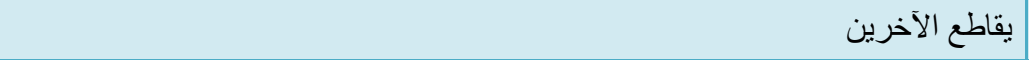 & .41 \\
\hline غالبا & أحيانا & ע & لا يتفطّن إلى أنّ سلوكه يسبّب ردود فعل سلبيّة من طرف الآخرين & .42 \\
\hline غالبا & أحيانا & ע & يترك مقعده في أوقات غير مناسبة & .43 \\
\hline غالبا & 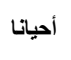 & ע & يفقد السيطرة على نفسه أكثر ممّا يفعل أصدقاؤه & .44 \\
\hline غالبا & أحيانا & $\gamma$ & يتفاعل بعنف أكثر من الأطفال الآخرين & .45 \\
\hline غالبا & أحيانا & ע & يبدأ دائما واجباته أو أنشطة الحياة اليومية في آخر لحظة & .46 \\
\hline غالبا & 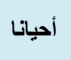 & ४ & يجد صعوبة في الثروع في إنجاز و اجباته المدرسية أو نشاطات الحياة اليومية & .47 \\
\hline غالبا & أحيانا & $\gamma$ & للديه صعوبة في تنظيم الأنشطة (الألعاب) مع أصدقائه & .48 \\
\hline غالبا & أحيانا & $y$ & لا يمكن أن يحتفظ بسر من الأسر ار لنفسه، لا يمكن أن يمنع نفسه من أن يقول ما لديه & .49 \\
\hline غالبا & أحيانا & $\gamma$ & | يؤثّر مسار الأحداث بسهولة على مز اجه & .50 \\
\hline غالبا & أحيانا & $y$ & لا يخطط مسبقا لإنجاز بواجباته المدرسية & .51 \\
\hline غالبا & أحيانا & $\gamma$ & ليست لديه روئية و اضحة لنقاط قوته ونقاط ضعفه & .52 \\
\hline غالبا & أحيانا & $\gamma$ & | أعماله الكتابية ليست منظمة & .53 \\
\hline غالبا & أحيانا & ע & | يتصرّف بطريقة فجّة، أو غير قادر على التحكّم في ردود أفعاله & .54 \\
\hline غالبا & أحيانا & ע & لديه صعوبات في ضبط تصر فاته & .55 \\
\hline غالبا & أحيانا & $\gamma$ & | يو اجه مشـاكل إن لم يكن تحت إثر اف ومر اقبة شخص ر اشد & .56 \\
\hline غالبا & أحيانا & $\gamma$ & بجد صعوبة في تذكّر الأشياء حتّى لبضع دقائق & .57 \\
\hline
\end{tabular}




\begin{tabular}{|c|c|c|c|c|}
\hline غالبا & 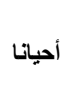 & ע & 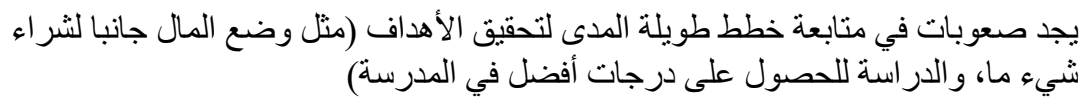 & .58 \\
\hline غالبا & أحيانا & ע & يبدو سخيفا جدا (يبدو أكثر غباء مما هو فعلا) & 59 \\
\hline غالبا & 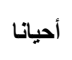 & $\gamma$ & لا يتقن عمله (مهمل، غير مرتّب) & .60 \\
\hline غالبا & 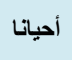 & ४ & ل يتّذذ أبيّ مبادرة & .61 \\
\hline غالبا & 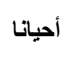 & ע & تنتبه نوبات غضب أو بكاء شديدة لكنها تنتهي فجأة & .62 \\
\hline غالبا & 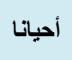 & ע & لا يدرك أنّ بعض أفعاله قد تزعج الآخرين أحيانا & .63 \\
\hline غالبا & 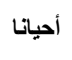 & ע & تؤدي بعض الأحداث الصغيرة إلى ردود فعل كبيرة لديه & .64 \\
\hline غالبا & 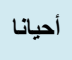 & ע & يتكلّم في أوقات غير مناسبة (عندما لا ينبغي) & .65 \\
\hline غالبا & أحيانا & ४ & يشتكي من كونه لا يجد ما يفعله & .66 \\
\hline غالبا & 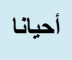 & ע & لا يجد أدو اته في غرفته أو في درج طاولته في القسم & .67 \\
\hline غالبا & أحيانا & y & يترك حاجاته الشخصيّة ور اءه أينما ذهب & 68 \\
\hline غالبا & 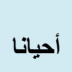 & ע & يترك الفوضى خلفه، و على الآخرين تنظيفها & .69 \\
\hline غالبا & أحيانا & y & يصبح متوتر ا بسر عة وبسهولة لأتفه الأسباب & .70 \\
\hline غالبا & 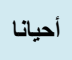 & ע & يتسكع في المنزل أو يقضي وقته في مشاهدة التلفاز & .71 \\
\hline غالبا & 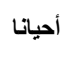 & ע & خز انته في حالة فوضى تامة & .72 \\
\hline غالبا & أحيانا & ע & يجد صعوبة في انتظار دوره & .73 \\
\hline غالبا & 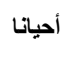 & ע & يضيّع مصروف جيبه، وو اجباته المدرسية، وما إلى ذلك & 74 \\
\hline غالبا & أحيانا & $\gamma$ & لا يجد ملابسه، نظار اته، أحذيته، ألعابه، كتبه، أقلامه وما إلى ذلك & 75 \\
\hline غالبا & أحيانا & $\gamma$ & يحصّّل على درجات سيئة في الامتحانات حنّى عندما يعرف الأجوبة صحيحة & 76 \\
\hline غالبا & أحياتا & ע & لا ينهي الأعمال التي تتطلب وقتا أطول في الإنجاز & .77 \\
\hline غالبا & أحيانا & $\gamma$ & لا بدّ من مر اقبته عن قرب & .78 \\
\hline غالبا & أحيانا & $\gamma$ & لا يفكّر في عو اقب عمل ما قبل القيام به & 79 \\
\hline غالبا & أحيانا & ע & يجد صعوبة في الانتقال من نشاط إلى آخر & .80 \\
\hline غالبا & أحيانا & $\gamma$ & يتململ، ويتحرّ كون دون توقّف & .81 \\
\hline غالبا & أحيانا & $\gamma$ & 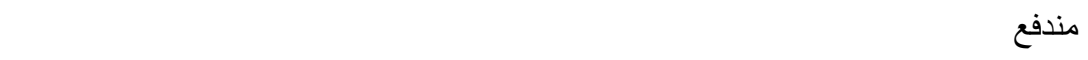 & .82 \\
\hline غالبا & أحيانا & $\gamma$ & عندما يتكلّم، يجد صعوبة في مو اصلة الحديث في نفس الموضوع & .83 \\
\hline غالبا & أحيانا & $\gamma$ & ينحصر اهتمامه في موضوع أو نشاط واحد فقط & .84 \\
\hline غالبا & أحيانا & $\gamma$ & يكرّر نفس الأشياء مر ات عديدة & .85 \\
\hline غالبا & أحيانا & $\gamma$ & في الصباح، لا يذهب إلى المدرسة مستعدا على النحو المناسب & .86 \\
\hline
\end{tabular}


Mots clés: Fonctions Exécutives, Développement, Culture, Liban.

Les FE ne se développent pas de manière homogène chez les enfants issus de différentes cultures. Peu d'études se sont intéressées à la question des FE dans le monde Arabe. L'un des principaux obstacles à l'établissement de telles études reste le manque d'outils d'évaluation adaptés à ces contextes culturels. Dans cette perspective, le protocole FEE, outil d'évaluation des fonctions exécutives chez l'enfant, a été adapté à la population libanaise. Ensuite, les trajectoires développementales de l'inhibition, la mémoire de travail, la flexibilité et la planification auprès de 100 enfants libanais ont été étudiées. Nous avons également étudié les influences du genre et du niveau d'éducation parental sur l'efficience des FE chez les enfants libanais. Les résultats ont montré un effet principal de l'âge sur les mesures d'inhibition, de mémoire de travail, de planification et de flexibilité.
L'effet du genre était non-significatif alors que l'effet $\mathrm{du}$ niveau d'éducation maternel et paternel était significatif. Ensuite, un garçon de 8 ans avec une épilepsie du lobe frontal a été évalué en utilisant des tests neuropsychologiques classiques ainsi que la batterie FEE et le questionnaire BRIEF adaptés à la langue Arabe. L'évaluation neuropsychologique a montré un profil suggérant un trouble d'acquisition du langage, un trouble déficitaire de l'attention avec hyperactivité, ainsi que des déficits exécutifs diffus. Les résultats du cas clinique ont donc montré des données préliminaires suggérant que la batterie FEE et le questionnaire BRIEF adaptés en langue Arabe sont sensibles aux difficultés exécutives accompagnant l'épilepsie du lobe frontal chez les enfants libanais.

\section{Title : Development of Executive Functions in Lebanese Children}

\section{Keywords: Executive Functions, Development, Culture, Lebanon.}

EF development is potentially influenced by culture and sociodemographic variables. However, relevant studies on EF in children rarely focus on Arabicspeaking, Middle Eastern children. The current study focused on adapting EF tests (CEF-B) for children to the Arabic language and examine the developmental trajectories of school-aged Lebanese children in four EF domains (inhibition, flexibility, working memory and planning) as well as the effects of gender and parent's education level. The study population included 100 Lebanese children aged from 6 to 12-years old who were grouped and matched for age, gender, and parental level of education. Results revealed a main effect of age on measures of inhibition, working memory and planning and to a lesser extent, flexibility. The effect of gender was non-significant whereas the effect of mother and father's level of education were significant.
Another objective of this study was to assess, through a clinical case study, the sensitivity of the Arabic version of the CEF-B and describe, for the first time, a dysexecutive profile in a Lebanese child. A comprehensive neuropsychological assessment was conducted on an 8-year old Lebanese boy with frontal lobe epilepsy. Among the tools used, Arabic adaptations of the CEF-B and the BRIEF were administered to the young boy to assess EF. Results suggested the presence of a Language Disorder, Attention Deficit/Hyperactivity Disorder, and major impairments in most EF skills. He showed EF impairments as assessed through Arabic adaptations of the CEF-B and the BRIEF (Parent form), providing preliminary evidence suggesting that those tests are sensitive to the EF difficulties accompanying FLE. 